\title{
11. GEOCHEMISTRY OF HYDROTHERMALLY ALTERED SEDIMENT, MIDDLE VALLEY, NORTHERN JUAN DE FUCA RIDGE ${ }^{1,2}$
}

\author{
Wayne D. Goodfellow ${ }^{3}$ and Jan M. Peter ${ }^{3}$
}

\begin{abstract}
Two distinct hydrothermal fluid upflow zones were penetrated during Ocean Drilling Program Leg 139 drilling in Middle Valley: Site 856, Bent Hill (BH), and Site 858, the Area of Active Venting (AAV). The BH upflow zone is a fossil hydrothermal fluid discharge conduit adjacent to a major sulfide deposit near the southern flank of a sediment mound. Hydrothermal minerals in this discharge conduit are zoned about a high-temperature, silicified core outward to weakly altered sediment as follows: (1) quartz + Fe-chlorite + muscovite + rutile; (2) albite + Mg-chlorite + muscovite + pyrite; (3) anhydrite + illite + barite + pyrite; and (4) calcite + illite + pyrite. The inner core has gained $\mathrm{Si}, \mathrm{Fe}, \mathrm{Al}, \mathrm{Mg}, \mathrm{S}, \mathrm{K}, \mathrm{Mn}, \mathrm{Cu}, \mathrm{Ba}, \mathrm{Zn}, \mathrm{Se}, \mathrm{Co}$, and $\mathrm{Cr}$, and lost $\mathrm{Ca}, \mathrm{Na}, \mathrm{CO}_{2}$, TOC (total organic C), As, and Sc. In the surrounding alteration zones, $\mathrm{Mg}$ and $\mathrm{Fe}$ have been added at the expense of alkali elements bound in detrital feldspar and micas.

The AAV upflow zone is associated with anhydrite-sulfide chimneys that are actively discharging $184^{\circ}-276^{\circ} \mathrm{C}$ fluids. Hydrothermal minerals are zoned from a fractured, veined, and brecciated core outward to weakly altered sediment as follows: (1) quartz + wairakite + epidote + pyrite; (2) quartz + epidote + chlorite; (3) albite + chlorite + illite + pyrite; (4) anhydrite + illite + pyrite; and (5) carbonate + illite + pyrite. The major elements added to the core of the conduit include $\mathrm{Ca}, \mathrm{Si}, \mathrm{Al}$, and $\mathrm{H}$; elements removed include $\mathrm{Fe}, \mathrm{Na}, \mathrm{K}, \mathrm{CO}_{2}$, TOC, Ba, $\mathrm{Sr}, \mathrm{Rb}, \mathrm{Zn}, \mathrm{As}, \mathrm{Cu}, \mathrm{Ni}$, and $\mathrm{V} .{ }^{87} \mathrm{Sr} /{ }^{86} \mathrm{Sr}$ ratios for wairakite-quartz from $\mathrm{Zone} \mathrm{Ib}(0.704853)$ are similar to average values for AAV vent fluids $(0.70424)$.

The textural, mineralogical, and chemical zonation about the AAV and $\mathrm{BH}$ upflow zones is consistent with precipitation from upflowing and outflowing hydrothermal fluid that mixed with heated down-drawn seawater at the margins of the discharge conduit. The inner core assemblages precipitated in response to reaction between sediments and end-member hydrothermal fluid, whereas the surrounding alteration zones formed by the reaction of sediments with chemically evolved hydrothermal fluids and heated entrained seawater. Although the BH and AAV upflow zones are similar in size and morphology, they are mineralogically and geochemically distinct and reflect contrasting fluid compositions, temperatures, fluid-sediment reaction conditions, and probably fluid sources.

At Site 857, hydrothermal minerals in sediments are zoned upward from fractured, brecciated, and veined sediments containing quartz \pm wairakite + epidote + chlorite (Zones Ic and Zone IIc) between 450 and $936 \mathrm{mbsf}$, to albite + chlorite + pyrite (300-450 mbsf) and carbonate-illite-pyrite (70-300 mbsf). Elements that have been markedly depleted from Zone Ic include $\mathrm{K}, \mathrm{Ba}, \mathrm{Na}$, $\mathrm{CO}_{2}, \mathrm{Rb}, \mathrm{TOC}, \mathrm{Cu}, \mathrm{Zn}, \mathrm{As}, \mathrm{Sb}, \mathrm{Se}, \mathrm{Be}$, and $\mathrm{Co}$; elements added are $\mathrm{Si}, \mathrm{Ca}, \mathrm{Al}$, and $\mathrm{Sr} .{ }^{87} \mathrm{Sr} /{ }^{86} \mathrm{Sr}$ ratios for wairakite-quartz in $\mathrm{Zone}$ Ic $(0.704094)$ are similar to ratios for average AAV vent fluids $(0.70424)$. The similarities of mineralogy, bulk chemical and isotope composition, and temperature (fluid inclusion temperatures of $250^{\circ}$ to $350^{\circ} \mathrm{C}$ ) between hydrothermally altered sediment in the core of the AAV upflow zone and altered sediment in the sill complex at nearby Site 857 indicate a common fluid source. The sediment-sill complex at the base of the sedimentary sequence near the transition from sedimentary to predominantly mafic igneous rocks represents a hydrothermal-reaction zone where elements in AAV end-member vent fluids were leached.

The Middle Valley hydrothermal system has evolved with time and consisted initially of (1) a reaction zone, probably in basaltic crust near a high-level magma body, where high-temperature, metal-rich "black smoker"-type fluids were generated, and (2) a secondary reaction zone in the sill complex near the base of the sedimentary pile where these high-temperature fluids were modified by reaction with sediments which probably contained anhydrite. It was this modified high-temperature system that generated the large, hydrothermally inactive BH massive sulfide deposit at Site 856. The active hydrothermal system at the AAV and south of $\mathrm{BH}$ is lower temperature and appears to be contained within the sediment-sill complex below about 450 mbsf. Hydrothermal fluids from this active system are generally $<300^{\circ} \mathrm{C}$ and metal-poor. Hydrothermal precipitates from these fluids consist of anhydrite-sulfide chimneys with $\mathrm{Cu} / \mathrm{Zn}$ ratios significantly greater than those for massive sulfides at $\mathrm{BH}$.
\end{abstract}

\section{INTRODUCTION}

Middle Valley is an oceanic rift at the northern extremity of the Juan de Fuca Ridge (Fig. 1) that has been partly filled by interbedded hemipelagic and turbiditic sediment. Seismic profiles show that the sedimentary sequence thickens from only a few meters near the margins of the rift to over 300 meters near the center and northward toward the Sovanco Transform where thicknesses exceed $1000 \mathrm{~m}$ (Davis and Villinger, 1992). Two major areas of hydrothermal fluid discharge and sulfide deposition have been described within Middle Valley: Site 856

\footnotetext{
${ }^{1}$ Mottl, M.J., Davis, E.E., Fisher, A.T., and Slack, J.F. (Eds.), 1994. Proc. ODP, Sci. Results, 139: College Station, TX (Ocean Drilling Program).

${ }^{2}$ Geological Survey of Canada Contribution No. 22293.

${ }^{3}$ Geological Survey of Canada, 601 Booth Street, Ottawa, Ontario, Canada K1A 0E8.
}

(Bent Hill $[\mathrm{BH}]$ ) and Site 858 (Area of Active Venting [AAV]) (Fig. 2; Davis et al., 1987; Goodfellow and Blaise, 1988; Goodfellow and Franklin, 1993; Davis, Mottl, Fisher, et al., 1992).

Unaltered to intensely altered hemipelagic and turbiditic sediment was sampled from Ocean Drilling Program (ODP) drill core recovered from Middle Valley. Hydrothermally altered sediment is associated with both fossil (Site 856) and active (Site 858) fluid-upflow zones, and with a hydrothermal-reaction zone within the sill-sediment complex below $450 \mathrm{mbsf}$ at Site 857 . The reaction zone at Site 857 is defined as a hydrothermal fluid reservoir that behaves essentially isothermally because of the high fracture-controlled permeability, and that is in equilibrium with end-member fluids that are actively venting at the AAV. This chapter describes the geochemistry of sediment cores with the objectives of characterizing both altered and unaltered hemipelagic and turbiditic sediment and quantifying chemical changes due to hydrothermal alteration. Furthermore, we relate these alteration effects to mineralogy and mineral chemistry, place constraints on 


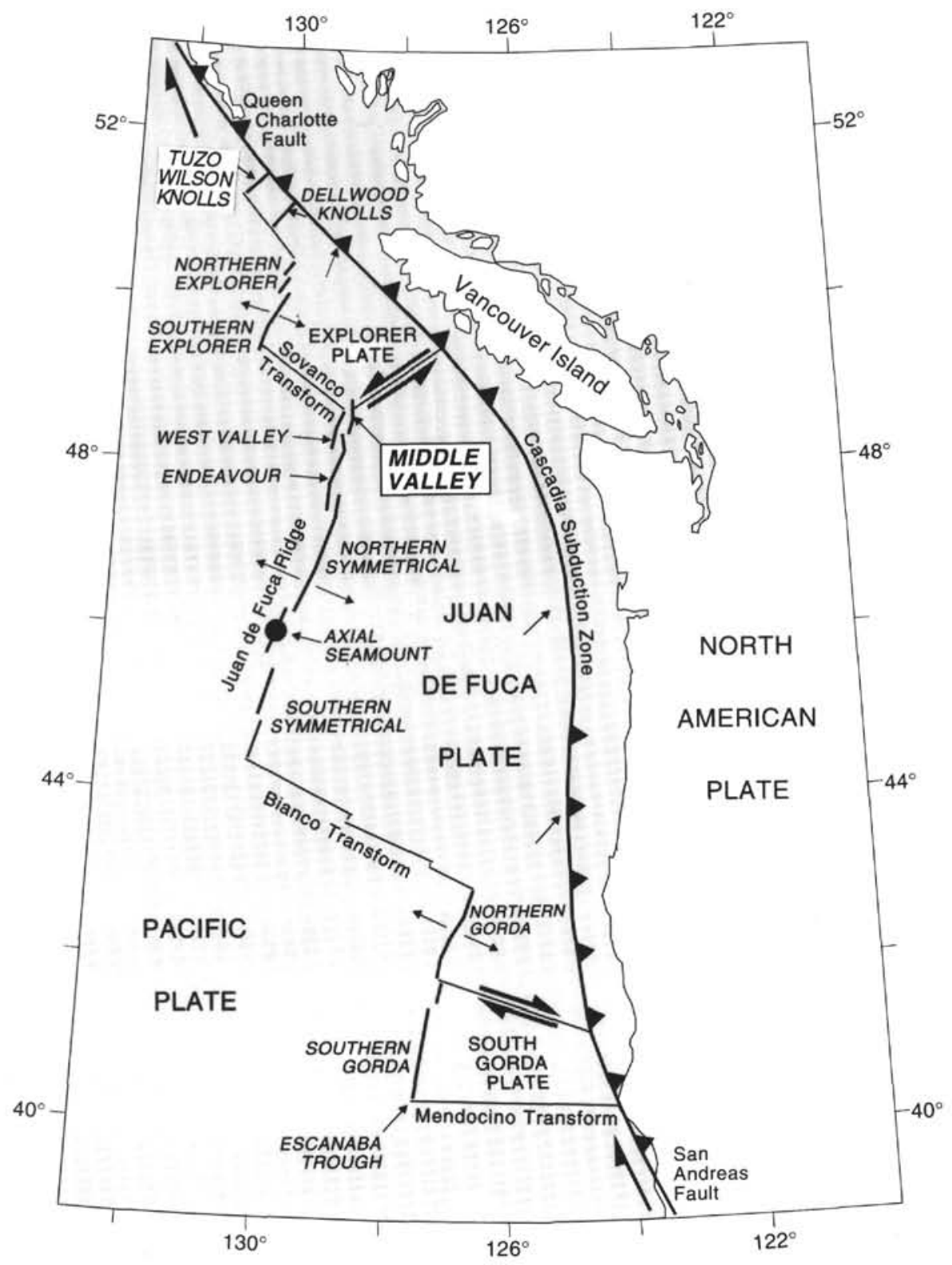

Figure 1. Map of the Juan de Fuca Ridge system showing the main tectonic elements and the location of Middle Valley at the northern extremity of the ridge. Arrows indicate the direction of subduction of the Juan de Fuca plate beneath western North America.

hydrothermal-reaction conditions as a function of distance from fluid discharge centers, and infer the sources of hydrothermal fluids.

\section{SAMPLING AND ANALYTICAL METHODS}

Unaltered hemipelagic and turbiditic sediments were collected from Holes $855 \mathrm{~A}, 855 \mathrm{~B}$, and $855 \mathrm{C}$ near the eastern margin of the Middle Valley Rift, the upper portions of Hole $856 \mathrm{~A}$ (above $20 \mathrm{mbsf}$ ) at Bent Hill, Hole 858A (above 10 mbsf) near the center of the rift, the Area of Active Venting, and from Hole $857 \mathrm{~A}, 3 \mathrm{~km}$ south of AAV (Davis and Sawyer, 1987; Davis, Mottl, Fisher, et al., 1992). The locations of the four sites are shown in Figure 2. Sediment cores were collected by hydraulic piston coring, extended core barrel diamond coring, and rotary drilling using a tricone bit. Six hundred and twelve samples were collected from the cores; sampling techniques are given in Davis, Mottl, Fisher, et al. (1992). Sediment cores with greater than $90 \%$ recovery were sampled at 5 - to 10 -m intervals, whereas cores with poor recovery were sampled at greater intervals. Soft or friable sediment was vacuum-impregnated with epoxy prior to preparation of pol- ished thin sections. The mineralogy of selected samples was determined using methods described by Chamley (1971) and Holtzapffel (1985). X-ray diffractograms were obtained with a General Electric XRD-3R diffractometer using $\mathrm{Cu}_{\mathrm{k} \alpha}$ radiation at $45 \mathrm{kv}$ and $16 \mathrm{~mA}$, and a scan rate of two degrees $2 \Theta$ per minute from $2.5^{\circ}$ to $25^{\circ} 2 \Theta$.

Samples were dried in an oven at $110^{\circ} \mathrm{C}$ and pulverized and ground to $<200$ mesh. A 0.5-g sample was fused with lithium metaborate and subsequently dissolved in $5 \% \mathrm{HNO}$. Samples were weighed before and after drying to determine the nonstructurally bound water content and porosity. Sediment samples were not washed prior to drying because of the possibility of dissolving highly soluble minerals (e.g., anhydrite, iron monosulfides) and the difficulty of recovering fine $(<0.1 \mu \mathrm{m})$ clays during the filtration of suspended sediment. Water-extractable Na was determined on most samples in order to correct for salt precipitated from pore water during drying. Analyses were performed at the Geological Survey of Canada using the following methods: induction coupled plasma-emission spectrometry: $\mathrm{SiO}_{2}$, $\mathrm{TiO}_{2}, \mathrm{Al}_{2} \mathrm{O}_{3}, \mathrm{~K} 2 \mathrm{O}, \mathrm{Na}_{2} \mathrm{O}, \mathrm{CaO}, \mathrm{MgO}, \mathrm{P}_{2} \mathrm{O}_{5}, \mathrm{MnO}, \mathrm{Fe}_{2} \mathrm{O}_{3} \mathrm{~T}$ (total iron), $\mathrm{Ba}, \mathrm{Ag}, \mathrm{Be}, \mathrm{Co}, \mathrm{Cr}, \mathrm{Cu}, \mathrm{La}, \mathrm{Ni}, \mathrm{Pb}, \mathrm{Sr}, \mathrm{V}, \mathrm{Yb}$ and $\mathrm{Zn}$; atomic absorp- 


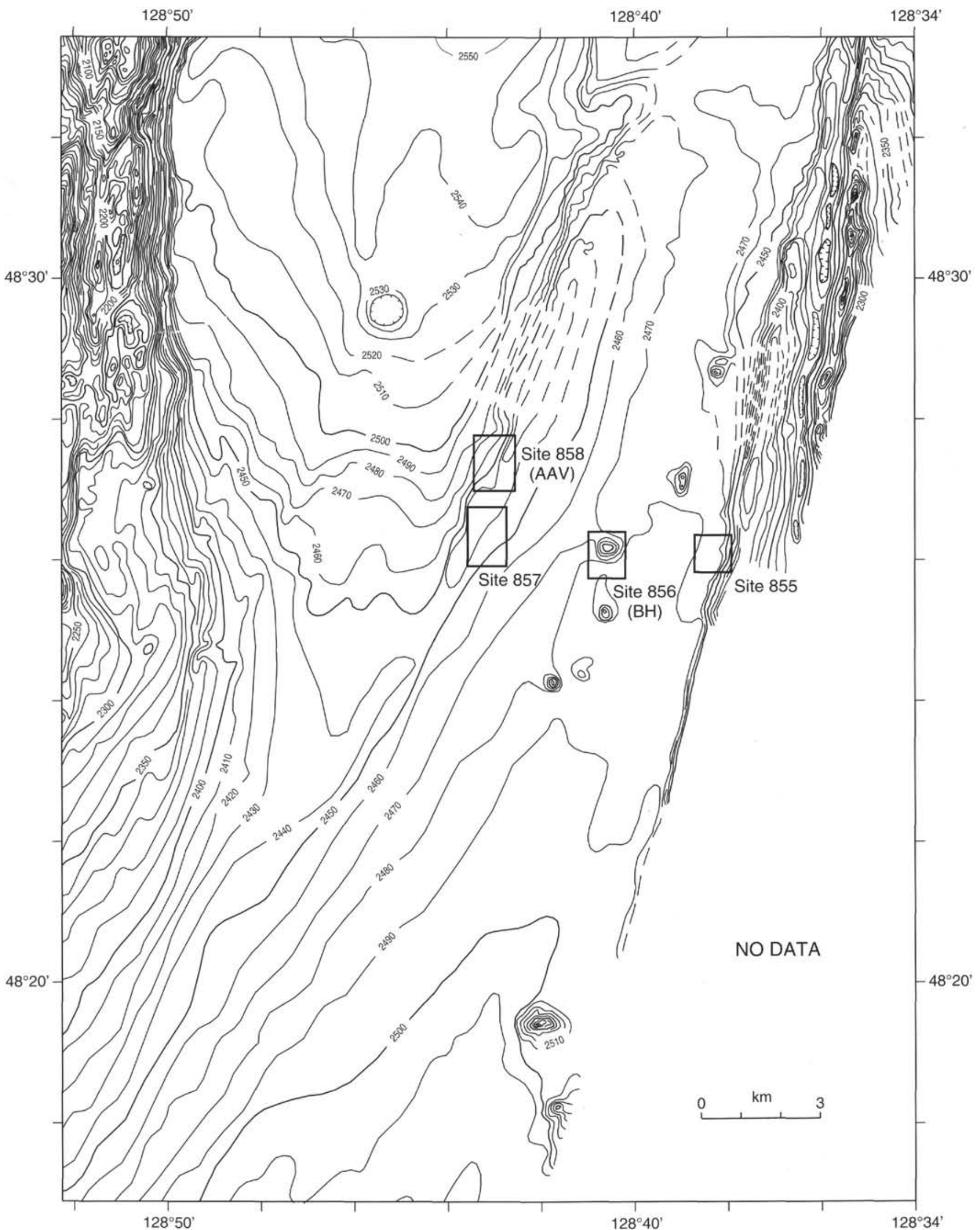

Figure 2. Seabeam bathymetric map of Middle Valley showing the location of Leg 139 drill sites (Davis and Sawyer, 1987). 
tion spectrometry: As, Sb, Se, Mo; combustion and wet chemical methods: $\mathrm{FeO}, \mathrm{Fe}_{2} \mathrm{O}_{3}, \mathrm{H}_{2} \mathrm{O}, \mathrm{CO}_{2}$, total organic carbon (TOC) and $\mathrm{S}$. Major and trace element contents were determined for all collected samples and are given in Table 1 (located at the end of this chapter).

\section{GEOLOGICAL SETTING}

\section{Unaltered Sediment}

The sedimentary sequence in Middle Valley consists of Holocene and Pleistocene interbedded hemipelagic and turbiditic sediment (Goodfellow and Blaise, 1988; Davis, Mottl, Fisher, et al., 1992). The uppermost sediments, which extend up to $12 \mathrm{~cm}$ below the seafloor, are water-saturated, oxidized, brownish gray, and of hemipelagic origin. Below this oxidized surface layer, hemipelagic sediment is commonly parallel-laminated and ranges in color from yellow-olive gray to olive gray and dark gray. In general, there is a change from olive gray to gray with depth. A dark gray hemipelagic sediment unit with horizontal zoophycos worm burrows occurs between 2 and 6 mbsf and has been used by Goodfellow et al. (1993) as a time-stratigraphic marker in the AAV. At depths greater than one meter, hemipelagic sediment is interbedded with medium- to dark-gray turbiditic silt and sand. Individual beds vary in thickness from $<1 \mathrm{~cm}$ to several meters, and typically fine upward into hemipelagic, silty clay. The silt-sand beds are commonly parallel-laminated and less commonly cross-laminated with sharp and scoured bases. The percentage of the sedimentary sequence represented by turbidites is highly variable (Davis, Mottl, Fisher, et al., 1992).

Microfossils are most common in the olive-gray muds and consist of foraminifers, nannofossils, diatoms, and radiolarians. Planktonic foraminifers (Globigerina buloides) in carbonate-rich beds from 75-77 $\mathrm{cm}$ depth in PAR 85-28 have a ${ }^{14} \mathrm{C}$ age of $13,490( \pm 210)$ aBP (Goodfellow and Blaise, 1988). This same species occurs at $64-66 \mathrm{~cm}, 78-79$ $\mathrm{cm}, 160-162 \mathrm{~cm}$, and $847-848 \mathrm{~cm}$ in PAR $85-34$ have been dated at $10,260( \pm 2,470), 12,090( \pm 170), 13,900( \pm 180)$ and $21,010( \pm 280)$ aBP (Goodfellow and Blaise, 1988; Goodfellow et al., 1993). Average Holocene sedimentation rates for the uppermost part of the sedimentary column calculated using these dates are $5.5-5.8 \mathrm{~cm} \mathrm{k.y.}{ }^{-1}$ for core PAR 85-28 from BH, and 6.2-6.4 cm k.y..$^{-1}$ for core PAR 85-34 from AAV. The lower sedimentation rate in core PAR85-28 may indicate that $\mathrm{BH}$ was a positive bathymetric feature during most of the Holocene. Average sedimentation rates for Holocene and latest Pleistocene sediment in core PAR85-34 are much higher $\left(40 \mathrm{~cm} \mathrm{k.y}^{-1}\right)$ due to the influx of turbidites in the late Pleistocene.

\section{Site 856, Bent Hill}

$\mathrm{BH}$ is one in a chain of sediment mounds that are oriented approximately north-northeast and are parallel to extensional faults bounding the Middle Valley rift (Fig. 2). BH is $60 \mathrm{~m}$ high by $400 \mathrm{~m}$ wide and is truncated to the west by a north-south fault (Goodfellow and Franklin, 1993; Davis, Mottl, Fisher, et al., 1992). Fault scarps separated by domino structures were observed by submersible along the western flanks of BH. Near the southern margin of $\mathrm{BH}$ is a $35 \mathrm{~m}$ high by 100 $\mathrm{m}$ wide hydrothermally inactive sulfide mound. The mound consists of brittle star-encrusted, angular blocks of sulfide rubble near the summit and interbedded hemipelagic sediment and clastic sulfides on the flanks. Most of the rubble is oxidized to a rusty brown color.

About $300 \mathrm{~m}$ south of $\mathrm{BH}$ are two smaller 25 -m-high sulfide mounds with blocks of sulfides on the flanks; near the summit of the northernmost mound, an anhydrite chimney was observed to vent $265^{\circ} \mathrm{C}$ clear fluids (Franklin and Leg 139 Scientific Party, 1992). The surface of the mound is covered by rubble composed of pale-gray anhydrite and gray to rusty-brown sulfide, and is surrounded by depressions that are partly filled with finer-grained, pale-gray and rusty-brown hydrothermal sediment. Shallow sediment cores from these depressions consist of interbedded, resedimented anhydrite and sulfide. Fauna are more abundant on the sulfide rubble than on the hemipelagic sediment and include spherical sponges, galatheid crabs, sea anemones, rattail fish, and rare shrimp (Goodfellow and Franklin, 1993).

\section{Stratigraphy and Sedimentology}

Locations of cores from Site 856 and the limits of BH mounds are shown in Figure 3. Cores from Holes 856A and 856B were collared on $\mathrm{BH}$, whereas the remaining holes penetrated the sulfide mound near the southern margin of BH (Fig. 3)(Davis, Mottl, Fisher, et al., 1992). The western margin of BH has a step and scarp morphology that probably resulted from reverse normal faulting. This faulting may have formed tilted slump blocks and mud-clast breccias observed in shallow cores (Goodfellow and Franklin, 1993). Multiple slumped sulfide and mud-clast breccia units that occur on the flanks of the sulfide mound have resulted in a complex stratigraphy and sedimentology in the $\mathrm{BH}$ area.

Cores from Holes $856 \mathrm{~A}$ and $856 \mathrm{~B}$ consist mainly of interbedded hemipelagic and turbiditic sediments that have been intruded by mafic sills (Davis, Mottl, Fisher, et al., 1992). Slumped and tilted massive sulfide beds occur between 18 and 30 mbsf in Hole 856B, and the sediment is brecciated between 30 and 60 mbsf. Sediments in both holes have been hydrothermally altered with the intensity of alteration generally increasing with depth.

\section{Site 858, Area of Active Venting}

Site 858 encompasses an 800 -m by 400 -m vent field (AAV) situated $2.4 \mathrm{~km}$ northwest of $\mathrm{BH}$ (Fig. 2), immediately east and on the down-thrown side of an extensional fault parallel to the rifted margins of Middle Valley. The AAV hosts at least 11 hydrothermal vents discharging hydrothermal fluids up to $276^{\circ} \mathrm{C}$ from anhydrite chimneys situated near the summit of sediment mounds (Franklin et al., 1992; Lydon et al., 1992; Goodfellow and Franklin, 1993; Butterfield et al., this volume). SeaMARC $1 \mathrm{~A}$ images show that the AAV occurs near a right-lateral offset of a rift-parallel extensional fault that penetrates the present-day seafloor. The vents and associated hydrothermal mounds are oriented northwest along what is thought to be a conjugate set of orthogonal extensional faults.

The AAV occurs in a bathymetric low and is an area of high acoustic reflectivity outlined by a SeaMARC 1 A side-scan sonar survey of the area (Goodfellow and Franklin, 1993; Fig. 4). The high reflectivity results from the roughness of mound exteriors, hydrothermal sulfide, sulfate and silicate sediment near vents, and the alteration of the uppermost sediment by hydrothermal fluids (Goodfellow et al., 1993). The correspondence between these features, high heat flow (Davis and Villinger, 1992), and pore fluids enriched in $\mathrm{Si}, \mathrm{Ca}$ and $\mathrm{Ba}$ and depleted in $\mathrm{Mg}$ (Lydon et al., 1991) suggests that the high acoustic reflectivity results from the advection of hydrothermal fluids through the sedimentary sequence.

Detailed observations of the AAV mound structures were made in 1990 using the submersible Alvin (Goodfellow and Franklin, 1993). Mounds typically range to $15 \mathrm{~m}$ high and $100 \mathrm{~m}$ in diameter and consist of a mixture of hydrothermal sediment and altered hemipelagic and turbiditic sediment. Anhydrite-sulfide chimneys venting $184^{\circ}$ to $276^{\circ} \mathrm{C}$ fluids were observed near the summit of most mounds. Mound surfaces consist of anhydrite-silicate-sulfide rubble formed from the collapse of chimneys and uplifted blocky sediment. The flanks of mounds are composed of sulfide rubble and blocky hemipelagic sediment. Vestimentiferan tube worms and clams cluster along fractures in the blocky sediment surface. Accumulations of dead clams were also observed on mound structures near extinct vent sites.

Hydrocarbon-impregnated barite-silica chimneys that formed at about $265^{\circ} \mathrm{C}$ occur on flat surfaces between mounds (Turner et al., 1991; Leitch, 1991). Hydrothermal bitumen which fills open spaces within barite chimneys is composed of a mixture of high- and lowtemperature organic alteration products (Simoneit et al., 1992). The aliphatic fraction represents organic matter that was weakly trans- 


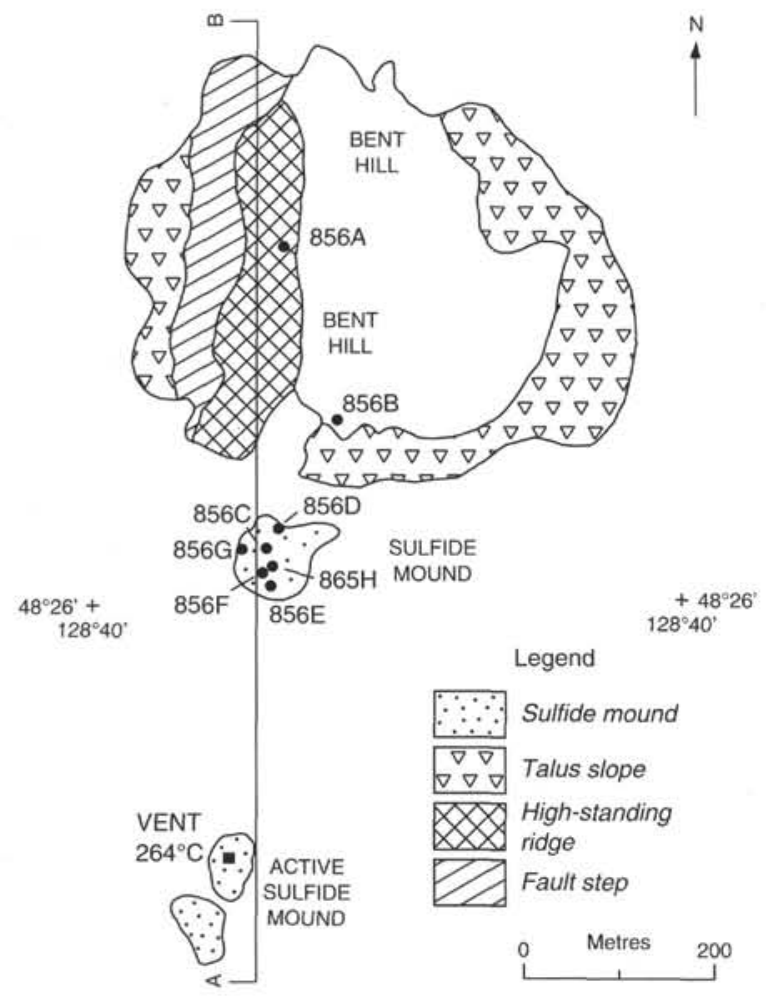

Figure 3. Map showing Bent Hill, the sulfide mound near the southern flank, and the southern sulfide mounds with a hydrothermally active anhydritesulfide chimney, and drill hole positions. Line A-B shows location of crosssection in Fig. 7.

formed at low temperatures $\left(50^{\circ}-120^{\circ} \mathrm{C}\right)$. The major polynuclear aromatic hydrocarbons are estimated to have formed at $>300^{\circ} \mathrm{C}$. The ${ }^{14} \mathrm{C}$ age of this hydrocarbon is $29,000 \mathrm{aBP}$ and indicates rapid recycling of sedimentary organic matter at shallow $(<12 \mathrm{~m})$ depths $(\mathrm{Si}-$ moneit et al., 1992).

Hydrothermal sediment forms the uppermost layer in all cores from mounds and ranges up to $80 \mathrm{~cm}$ in thickness (Goodfellow and Franklin, 1993). This sediment consists of crudely interbedded, clastic hydrothermal sediment that probably formed by the partial dissolution and collapse of inactive anhydrite-sulfide chimneys. The clastic beds are poorly sorted, show no visible grading, and are composed of anhydrite, gypsum, sulfide, and hydrothermal clay clasts in a fine-grained matrix of similar composition. The acicular gypsum crystals are morphologically similar to anhydrite in active chimneys, suggesting that gypsum formed by the hydration of anhydrite. Individual clasts range up to 4 $\mathrm{cm}$ in diameter and average $0.5 \mathrm{~cm}$ in diameter. The proportions of sulfide and hydrothermal clay relative to anhydrite increase with denth, suggesting retrograde dissolution of anhydrite (Blount and Dickson, 1969) as the sediment becomes buried. In core ALV-2255-5-1P, clastic anhydrite and sulfide beds overlie a 3-cm-thick bed of black massive sulfide containing fine-grained pyrrhotite, chalcopyrite, pyrite, sphalerite, galena, and anhydrite (Goodfellow and Franklin, 1993). This massive sulfide bed conformably overlies hemipelagic sediment that has been hydrothermally altered to talc and $\mathrm{Mg}$-rich smectite.

Fauna in the AAV are limited in abundance but are remarkably specious (Juniper et al., 1992). Fifty-six vent species were documented; 15 of these are new. The fauna assemblage is dominated by five species: a vestimentiferan (Ridgeia sp.), a limpet ( $L$. fucensis), two snails (D. globulus and $P$. variabilis) and a polychaete (A. galapagensis).

Core was recovered from five holes (Holes $858 \mathrm{~A}, 858 \mathrm{~B}, 858 \mathrm{C}$, $858 \mathrm{D}$, and $858 \mathrm{~F})$ at Site 858 that were drilled along a transect across an active vent field (Fig. 4) (AAV, Site 858; Davis, Mottl, Fisher, et al., 1992). None of the holes cored an active vent, although Hole 858B

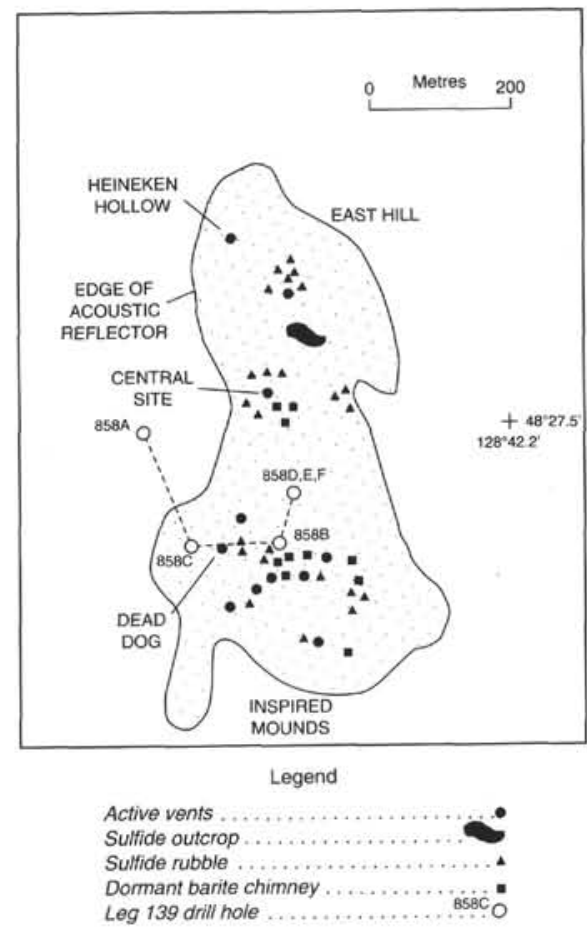

Figure 4. Map of the Area of Active Venting showing the limits of the acoustically reflective area, active vents and mounds, faults, and Site 858 drill hole positions. Dashed line indicates profile shown in Fig. 5.

was collared near the summit of a sediment mound within $10 \mathrm{~m}$ of anhydrite chimneys that were venting $276^{\circ} \mathrm{C}$ hydrothermal fluids. In Hole $858 \mathrm{~B}$, two beds of green saponitic sediment were intersected within $2 \mathrm{~m}$ of the seafloor, and a sulfide-anhydrite bed less than 0.5 $\mathrm{m}$ thick was cored between 10 and $12 \mathrm{mbsf}$. The saponitic sediment is textually and chemically similar to hydrothermal sediment intersected in shallow cores from the AAV (Goodfellow et al., 1993). Both the saponite and sulfide beds occur within hemipelagic silty clay and turbiditic silt. In Hole $858 \mathrm{~B}$, hemipelagic sediment is intensely altered to saponite between 20 and 30 mbsf.

Hole $858 \mathrm{C}$ was collared within the acoustically reflective area about $100 \mathrm{~m}$ west of active vents (Fig. 4) and penetrated unaltered and hydrothermally altered hemipelagic and turbiditic sediments (Fig. 5). Holes $858 \mathrm{D}$ and $858 \mathrm{~F}$ were collared within several meters of each other and about $100 \mathrm{~m}$ north of a sediment mound with hydrothermally active chimneys (Fig. 4). These holes intersected weakly altered, hemipelagic and turbiditic sediment ( 0 to $30 \mathrm{mbsf}$ ) that is underlain by lithified, brecciated, fractured, veined, and intensely altered sediment (Fig. 6) in a zone interpreted as major hydrothermal fluid-upflow zone.

\section{Stratigraphy and Sedimentology}

Unaltered hemipelagic and turbiditic sediments from Site 858 are similar to sediments recovered at Site 855 and Hole 857A. The turbidites are characterized by medium- to dark-gray silt and sand beds that commonly display sharp, scoured bases, and which become finergrained upward to olive-gray hemipelagic silty clay. Most turbidite beds are parallel-laminated and some are cross-laminated. Thicknesses of these beds are highly variable and range from $<1 \mathrm{~cm}$ to $>1 \mathrm{~m}$ (Davis, Mottl, Fisher, et al., 1992).

Based on examination of shallow $(<12 \mathrm{~m})$ cores, individual beds are laterally continuous across AAV, although the sediment thickness above a "Marker Unit" varies laterally (Goodfellow et al., 1993). The "Marker Unit" is a distinctive medium-gray hemipelagic mud typically less than $10 \mathrm{~cm}$ thick and composed of up to six near-horizontal zoophycos worm burrows. Isopach contour maps of sedimentary 


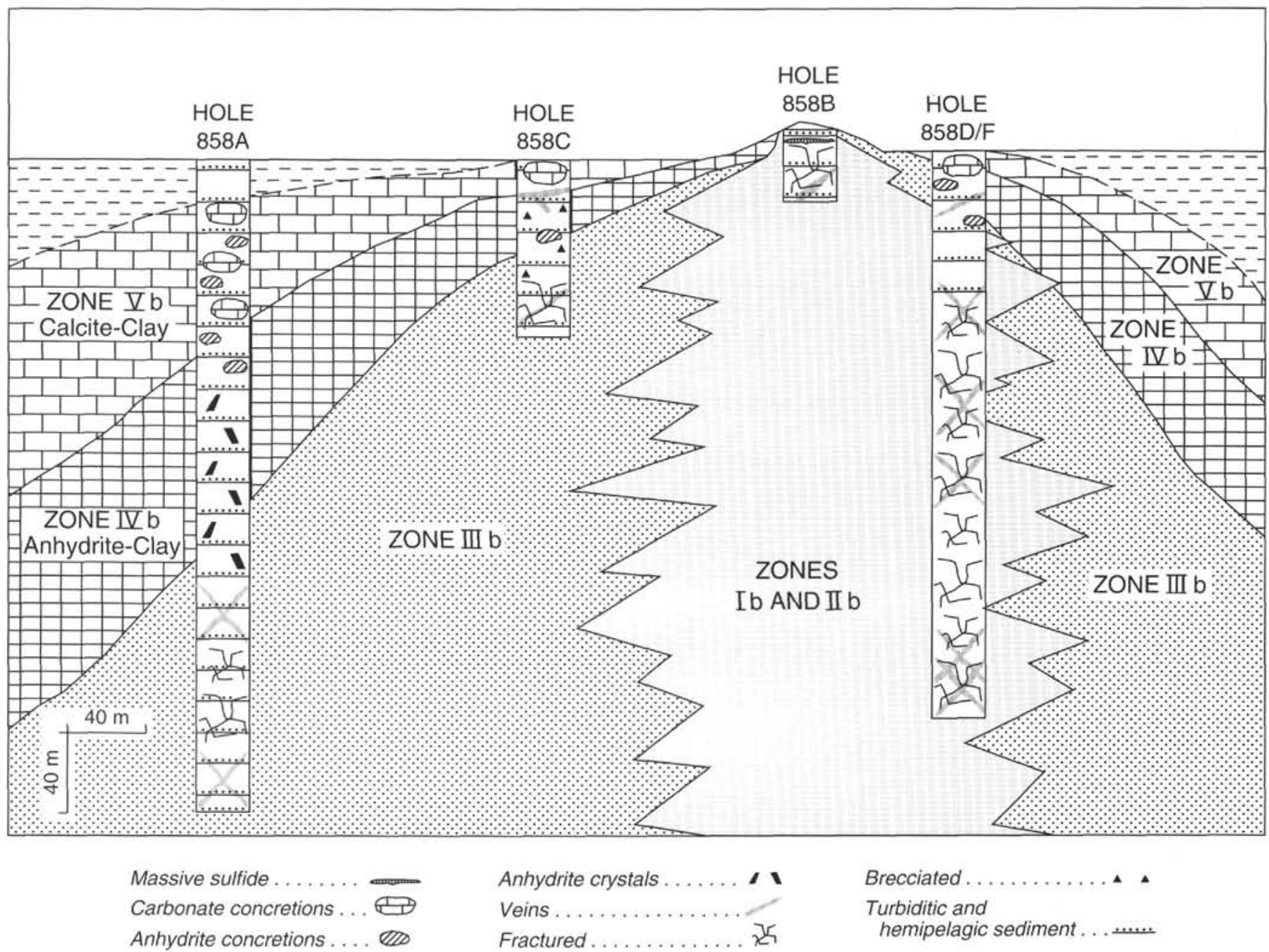

Figure 5. Geological cross-section of AAV (Site 858) showing the different hydrothermal alteration zones. Mineralogy of alteration zones is as follows: Zone Ib (quartz-wairakite-epidote-pyrite); Zone IIb (quartz-epidote-chlorite); Zone IIIb (albite-chlorite-illite-pyrite); Zone IVb (anhydrite-illite-pyrite); Zone Vb (calciteillite-pyrite); Zone VIb (saponite-talc-pyrite).

units above the "Marker Unit" define two areas where sediment thicknesses exceed $500 \mathrm{~cm}$, compared to $<400 \mathrm{~cm}$ outside the AAV, indicating that the AAV has subsided after deposition of the wormburrowed "Marker Unit." Based on an average sedimentation rate of $40 \mathrm{~cm} \mathrm{k.y.-1}$ for the uppermost $7.5 \mathrm{~m}$ of sediment in Middle Valley (Goodfellow and Blaise, 1988; Goodfellow et al., 1993), subsidence in the AAV was initiated as early as $13,000 \mathrm{yr}$ ago. Both areas where sediments thicken correspond to vent fields (Goodfellow and Franklin, 1993). This subsidence likely resulted from the dehydration of sediments in response to heating by upward-migrating hydrothermal fluids. Faulting is a less likely mechanism within AAV because the areas where sediments thicken do not extend north and south along a surface-penetrating fault that is visible on SeaMARC IA images (Goodfellow and Franklin, 1993).

\section{Hydrothermal Reaction Zone (Site 857)}

Site 857 is about $3 \mathrm{~km}$ south of AAV (Site 858 ) and $2.2 \mathrm{~km}$ west of BH (Site 856) (Fig. 1). Because Holes 857A, 857C, and 857D were drilled within $200 \mathrm{~m}$ of each other, they are considered to represent a composite stratigraphic section of Site 857 to a depth of $936.2 \mathrm{mbsf}$. This composite section consists of interbedded hemipelagic and tur- biditic sediment between 0 and $471.1 \mathrm{mbsf}$ and intercalated mafic sills and hydrothermally altered hemipelagic and turbiditic sediment from 471.1 to 936.2 mbsf (Davis, Mottl, Fisher, et al., 1992). The intensely altered nature of sills and sediment between about 471 and $936 \mathrm{mbsf}$ indicates that they have reacted extensively with hydrothermal fluid.

\section{Stratigraphy and Sedimentology}

The stratigraphy of Site 857 comprises four lithostratigraphic subdivisions (Davis, Mottl, Fisher, et al., 1992). Unit I consists of Holocene to Late Pleistocene hemipelagic sediment with minor finegrained turbidite beds; Unit IIa is composed of non- or weakly-indurated hemipelagic and turbiditic sediments; Unit Illb is similar to Unit IIa but is moderately to well-indurated; and Unit IIc consists of hydrothermally altered hemipelagic and turbiditic sediments intercalated with mafic igneous sills (Davis, Mottl, Fisher, et al., 1992). Hemipelagic sediment is olive-green to gray in color and weakly bedded and bioturbated. Turbidite beds are medium to dark gray in color, variable in grain size and thickness, typically display sharp and commonly scoured bases, are either parallel- or cross-laminated, and fine upward to hemipelagic silty clay. 


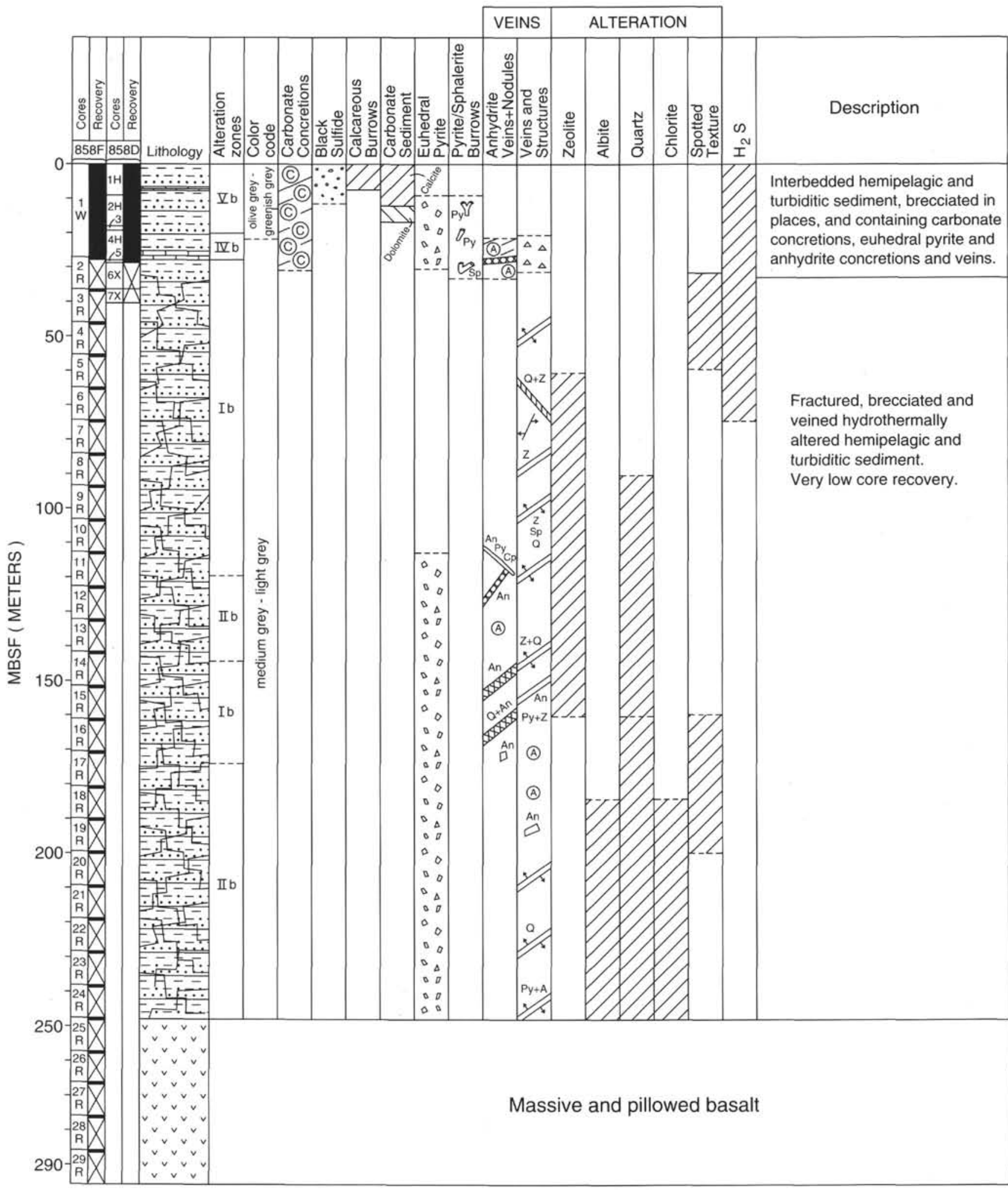

\section{LEGEND}
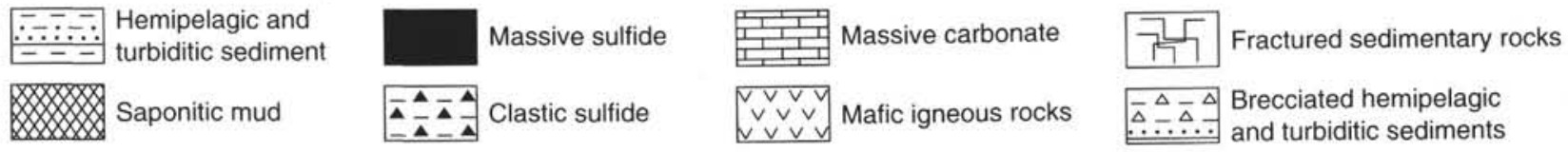

Figure 6. Stratigraphic section of Holes $858 \mathrm{D}$ and $858 \mathrm{~F}$ showing the general sedimentology, structures, textures, and alteration mineralogy. 


\section{PETROGRAPHY AND MINERALOGY}

\section{Unaltered Sediment}

X-ray diffraction analyses of bulk turbiditic sediment indicate the presence of the following minerals in order of decreasing abundance: quartz, plagioclase, muscovite, chlorite, amphibole, and minor biogenic calcite (Goodfellow et al., 1993; Leybourne and Goodfellow, this volume). In addition, turbiditic sand and silt generally contain minor amounts of epidote, magnetite, zircon, sphene, and apatite. Quartz examined by scanning electron microscopy (SEM) occurs as equant, abraded grains, whereas feldspar grains are equant to elongate. Detrital feldspars consist of plagioclase, $\mathrm{K}$-feldspar, and minor albite. The $\mathrm{Ca}$ content of plagioclase is variable and ranges up to $30 \mathrm{~mol} \%$ $\mathrm{CaO}$ (Leybourne and Goodfellow, this volume). Chlorite and muscovite, the most common phyllosilicates, occur as irregular grains or as clusters of ragged flakes that are detrital in origin. Chlorite analyzed by scanning electron microscope-energy dispersive analyses (SEM$\mathrm{EDX}$ ) has a $\mathrm{Mg} / \mathrm{Fe}$ weight ratio less than 1.0 (Leybourne and Goodfellow, this volume).

Hemipelagic silty clay consists of foraminifers, diatoms, radiolarians, nannofossils, detrital quartz, plagioclase, muscovite, chlorite and amphibole, and authigenic clay. The $<2 \mu \mathrm{m}$ fraction contains, in order of decreasing abundance, chlorite, illite, feldspar, amphibole, and quartz (Goodfellow and Blaise, 1988; Goodfellow et al., 1993; Leybourne and Goodfellow, this volume).

Holocene sediments are relatively rich in smectite and irregular mixed-layer clay compared to Late Pleistocene sediments, which contain a higher proportion of sedimentary chlorite and illite. Patches and disseminations of black diagenetic monosulfide occur throughout hemipelagic sediment and are most abundant in intervals rich in biogenic components.

\section{Bent Hill (Site 856)}

The alteration mineralogy and mineral chemistry are described by Leybourne and Goodfellow in a companion chapter in this volume. Alteration minerals are zoned vertically within holes and laterally between holes, from high-temperature assemblages (up to $338^{\circ} \mathrm{C}$; Peter et al., this volume) near the base of Hole 856B to lower temperature assemblages near the top, and from generally higher temperature assemblages in Hole 856B to lower temperature assemblages in Hole $856 \mathrm{~A}$. The temperature of hydrothermal alteration decreases, therefore, away from the massive sulfide mound near the southern margin of BH (Fig. 3).

Five hydrothermal alteration zones have been recognized in Holes $856 \mathrm{~A}$ and $856 \mathrm{~B}$; these are described below (refer also to Leybourne and Goodfellow, this volume; Fig. 7). The roman numerals increase from the core to the margins of the upflow zone, and the letter indicates the area (e.g., $\mathrm{a}=\mathrm{BH} ; \mathrm{b}=\mathrm{AAV} ; \mathrm{c}=$ Site 857).

\section{Zone Ia-1}

\section{(Quartz-Chlorite-Muscovite-Rutile-Pyrrhotite-Chalcopyrite)}

This zone is characterized by silicification, brecciation, and sulfide veining near the base of Hole $856 \mathrm{~B}$ (Fig. 7). In places, the sediments are bleached pale gray due to the addition of hydrothermal quartz. Biogenic carbonate and most of the organic matter have been destroyed by alteration processes. Fluid inclusion temperatures measured in hydrothermal quartz range up to $338^{\circ} \mathrm{C}$ (Peter et al., this volume). Pyrrhotite and chalcopyrite are the dominant sulfides, although minor sphalerite occurs locally.

\section{Zone Ia-2 (Quartz-Chlorite-Smectite-Feldspar)}

This zone forms a narrow (8-10-m-wide) interval of silicified, chloritized, and demagnetized sediment at the base of Hole 856B. It is distinguished from Zone Ia- 1 by generally lower contents of quartz and sulfides and higher $\mathrm{Mg} / \mathrm{Fe}$ ratios in chlorite (Leybourne and Goodfellow, this volume). Magnetite, biogenic carbonate, organic matter, and detrital feldspar have been destroyed. Euhedral to subhedral pyrite forms concretions and ubiquitous fine-grained disseminations.

\section{Zone IIa (Albite-Chlorite-Muscovite-Pyrite)}

This zone occurs between 70 and $110 \mathrm{mbsf}$ in Hole 856B. The hemipelagic sediment consists of dark gray and indurated silty claystone. Detrital feldspars are albitized and chloritized. Euhedral to subhedral pyrite forms concretions and occurs as fine-grained disseminations between detrital grains. Magnetite, biogenic carbonate, and organic matter have been destroyed.

\section{Zone IIIa (Anhydrite-Illite-Pyrite)}

Zone IIIA occurs between 30 and 70 mbsf in Hole 856B (Fig. 8) and between 82 and 114 mbsf in Hole 856A (Fig. 9). This zone consists of anhydrite molds, hydrothermal clay, euhedral to subhedral pyrite, and barite. The molds are similar in morphology and size to tabular anhydrite. The high sulfate content of pore fluids from this zone indicates that not all the authigenic anhydrite has dissolved (Davis, Mottl, Fisher, et al., 1992). The hydrothermal clay is morphologically and compositionally similar to $\mathrm{Mg}$-rich smectite described in shallow cores from the AAV (Goodfellow et al., 1993).

\section{Zone IVa (Calcite-Illite-Pyrite)}

This zone does not occur in Hole 856B due to the truncation of altered sediments by a major slump of bedded massive sulfides and interbedded hemipelagic sediment (Figs. 7 and 8). However, an alteration assemblage of calcite, disseminated subhedral to euhedral pyrite, and $\mathrm{Mg}$-rich smectite does occurs between 15 and $82 \mathrm{mbsf}$ in Hole 856 A (Fig. 9). Calcite occurs as concretions up to several $\mathrm{cm}$ across, cemented worm burrows, and carbonate cement. $\mathrm{Mg}$-rich smectite replaces hydrothermal sediment and infills interstices between detrital grains.

\section{Area of Active Venting (Site 858)}

Six hydrothermal alteration zones have been recognized in cores from Site 858 (Fig. 6; see also Leybourne and Goodfellow, this volume; Peter et al., this volume). The alteration minerals are zoned laterally and vertically about a moderate-temperature $\left(260^{\circ}\right.$ to $\left.300^{\circ} \mathrm{C}\right)$ inner core near active vents to a low-temperature $\left(<100^{\circ} \mathrm{C}\right)$ outer zone. The characteristic mineral assemblages are described below proceeding from the core to the outer margins of the zones of hydrothermal fluid upflow.

\section{Zone Ib (Quartz-Wairakite-Epidote-Pyrite)}

Zone $\mathrm{Ib}$ is restricted to the core of the upflow zone and was intersected in Holes $858 \mathrm{~F}$ between 28 and $120 \mathrm{mbsf}$, and 142 and $173 \mathrm{mbsf}$ (Fig. 5). This hole penetrated a high-standing volcanic structure at about 250 mbsf (Davis, Mottl, Fisher, et al., 1992). The sediments here are indurated, brecciated, fractured, veined, and variably replaced by hydrothermal minerals. Hydrothermal minerals consist of intergrown euhedral to subhedral quartz, wairakite, epidote, pyrite, and minor sphalerite. Detrital quartz is commonly overgrown by secondary quartz, and the clay minerals are recrystallized (Leybourne and Goodfellow, this volume).

\section{Zone IIb (Quartz-Chlorite-Epidote-Pyrite)}

This zone occurs between 120 and 142 mbsf, and 173 and 249 mbsf in Hole 858F (Fig. 6). The sediment is lithified and locally fractured, brecciated, and veined. Alteration minerals are quartz, chlorite, and epidote. Quartz forms overgrowths on detrital quartz grains, 


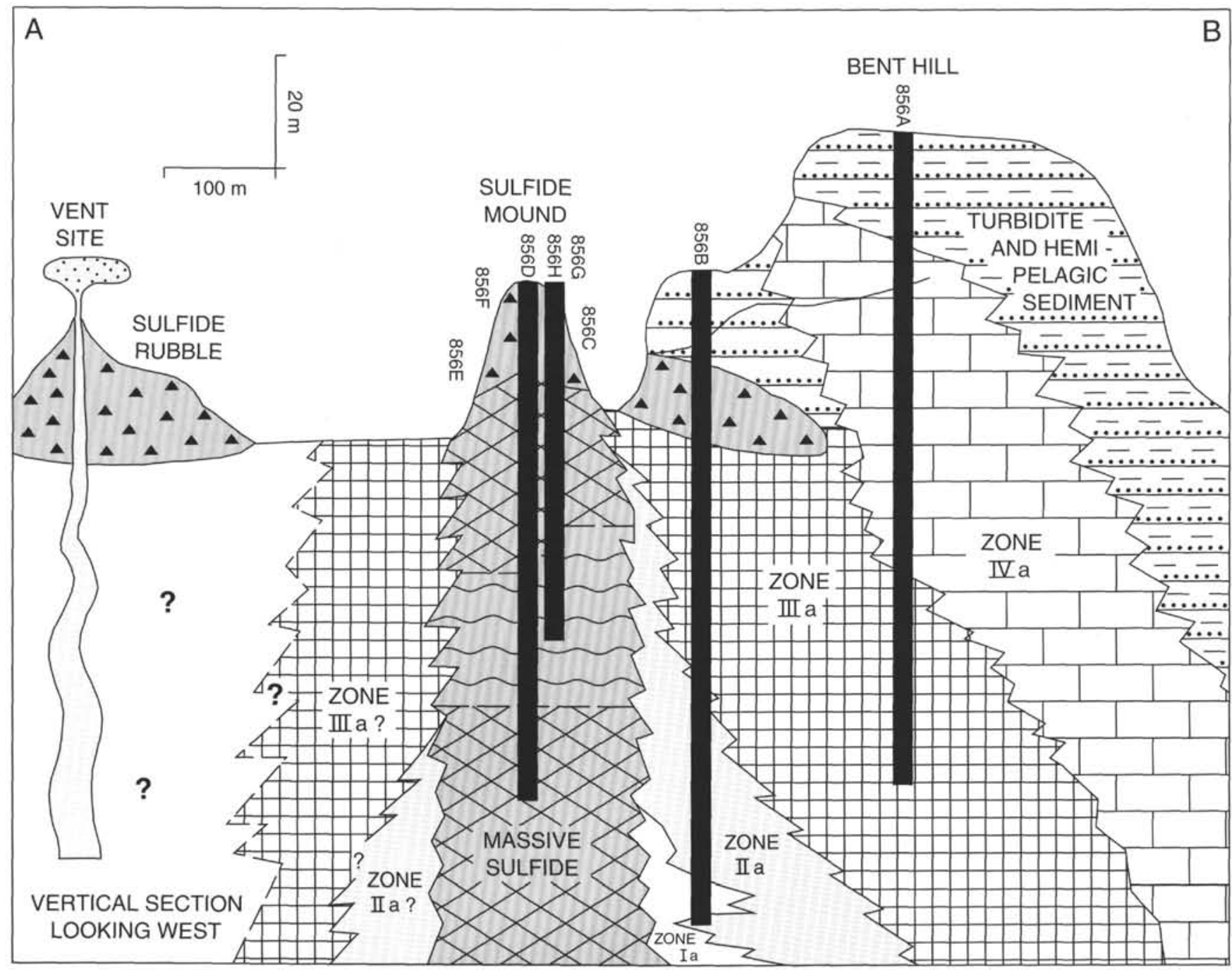

Figure 7. North-south profile of Bent Hill (Site 856) and sulfide mounds showing the distribution of hydrothermal alteration about the Bent Hill massive sulfide deposit. Hold positions are also shown. Profile location shown in Fig 3. Mineralogy of alteration zones is as follows: Zone Ia-1 (quartz-chlorite-muscovite-rutilepyrrhotite-chalcopyrite); Zone Ia-2 (quartz-chlorite-smectite-feldspar); Zone IIa (albite-chlorite-muscovite-pyrite); Zone IIIa (anhydrite-illite-pyrite); Zone IVa (calcite-illite-pyrite).

whereas chlorite and epidote replace detrital feldspars. Euhedral pyrite commonly replaces magnetite and amphibole and occurs between detrital grains. Anhydrite-pyrite-chalcopyrite veins locally crosscut this zone.

\section{Zone IIIb (Albite-Chlorite-Pyrite)}

Zone IIIb occurs between 175 and 320 mbsf in Hole 858A (Fig. 10 ) and between 34 and 92 mbsf in Hole 858C (Fig. 11). This zone consists of hydrothermally indurated and brecciated hemipelagic and turbiditic sediment that is locally cut by anhydrite veins. Alteration minerals are albite (after plagioclase), chlorite (after K-feldspar), and euhedral pyrite (after magnetite and amphibole). Euhedral pyrite also occurs disseminated throughout hemipelagic sediment and in the interstices between detrital mineral grains. Zone IIIb is textually and mineralogically similar to alteration Zone Ila at $\mathrm{BH}$.

\section{Zone IVb (Anhydrite-Illite-Pyrite)}

Zone IVb occurs above Zone IIIb in Holes 858A (Fig. 10) and 858C (Fig. 11) and consists of moderately indurated, medium- to dark-gray hemipelagic and turbiditic sediment. Anhydrite forms authigenic palegray to white, randomly oriented tabular crystals and white, sub- rounded concretions that occur throughout hemipelagic sediment. Authigenic illite and euhedral to subhedral pyrite occur throughout Zone IVb. Pyrite replaces detrital magnetite, forms concretions, and occurs as disseminations throughout hemipelagic sediment.

\section{Zone $\mathrm{Vb}$ (Calcite-Clay-Pyrite \pm Barite)}

Zone $\mathrm{Vb}$ occurs at shallow depths within Holes 858A (Fig. 10), 858C (Fig. 11), and 858D (Fig. 6). Hemipelagic sediment is weakly indurated except where it is locally brecciated and clasts are cemented by calcite. Calcite also forms irregular concretions up to $8 \mathrm{~cm}$ in diameter; these occur above the more massive carbonate units in Hole 858C (Fig. 11). Euhedral to subhedral pyrite replaces worm burrows and occurs as disseminations throughout silty clay and between detrital grains in turbidite beds.

\section{Zone VIb (Saponite-Pyrite)}

Zone VIb occurs between 24 and 38 mbsf in Hole 858B (Fig. 12), which is collared near active vents (Fig. 4). This sediment consists of pale gray, brecciated hemipelagic silt clay that has been intensely altered to saponite and euhedral pyrite. Quartz and anhydrite line vugs and form veins that crosscut sedimentary layers. 


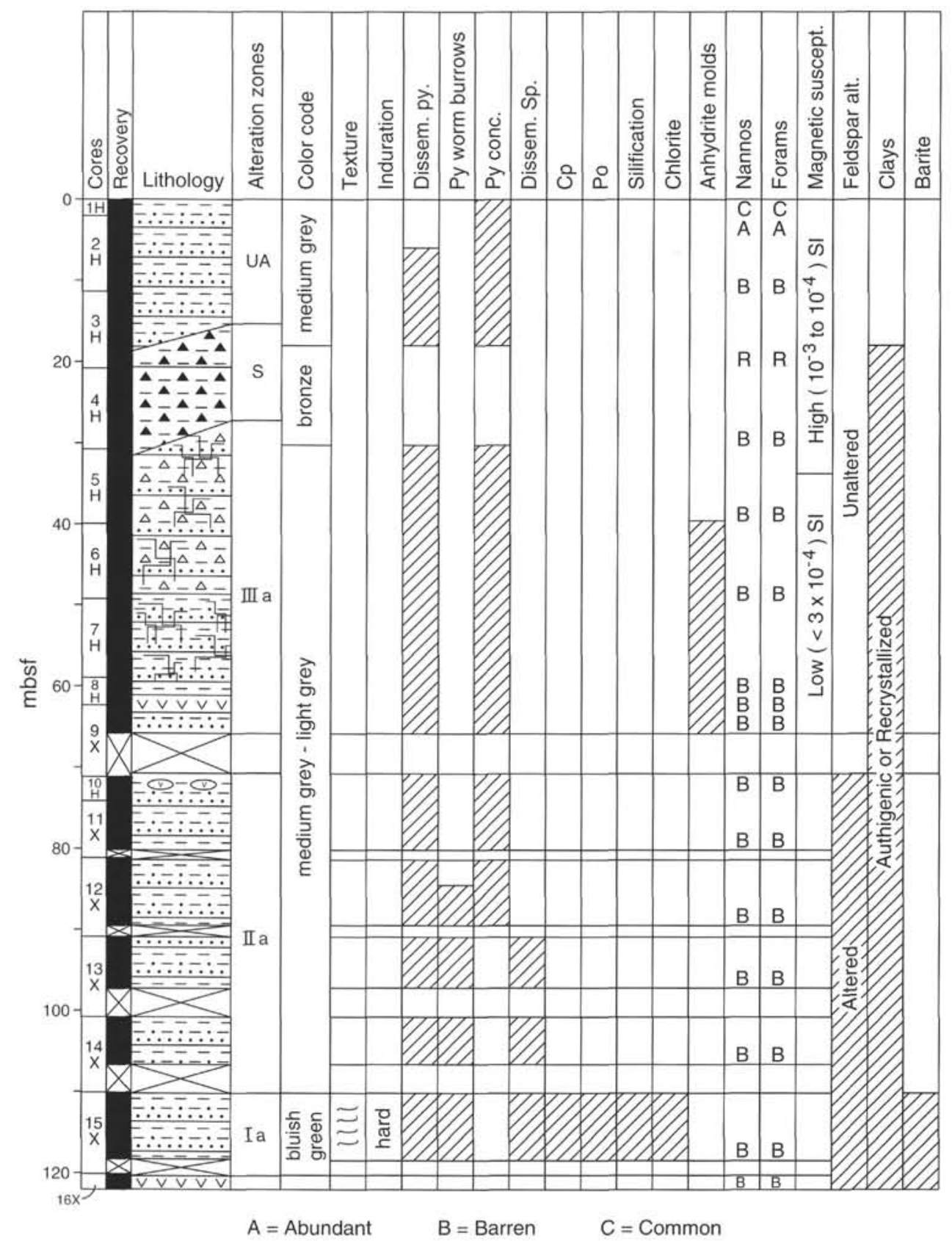

Figure 8. Stratigraphic section of Hole 856B showing the general sedimentology, structures, textures, hydrothermal minerals, and alteration zones.

\section{Reaction Zone (Site 857)}

Hole 857 A consists mainly of unaltered, weakly indurated, finegrained hemipelagic and turbiditic sediments that have undergone diagenesis and burial metamorphism. In Hole $857 \mathrm{C}$, however, the hemipelagic and turbiditic sediments are increasingly hydrothermally altered to a depth of $570 \mathrm{mbsf}$ (Fig. 13). Four alteration zones have been recognized: Zone Ic and IIc (quartz-wairakite-epidote-chlorite; 450-936 mbsf, Holes 857C and 857D); Zone IIIC (albite-chloritepyrite; $300-450 \mathrm{mbsf}$, Hole $857 \mathrm{C}$ ); and Zone IVc (calcite \pm dolomiteclay-pyrite; 60-300 mbsf, Hole $857 \mathrm{C}$ ). Mineralogical changes include the breakdown of Fe-bearing phases, reduction of all $\mathrm{Fe}^{3+}$ to $\mathrm{Fe}^{2+}$, recrystallization of clay minerals, and precipitation of subhedral to euhedral pyrite. Calcite concretions and cement occur between 60 and $380 \mathrm{mbsf}$, whereas dolomite is restricted to between 80 and 120 mbsf (Leybourne and Goodfellow, this volume). A plot of bulk $\mathrm{CaO}$ vs. $\mathrm{CO}_{2}$ shows that most samples containing $>0.2$ mole percent $\mathrm{CaO}$ and $\mathrm{CO}_{2}$ plot near a line representing stoichiometric calcite or dolomite (Fig. 14). Between 240 and 340 mbsf, detrital plagioclase is albitized. Below about $420 \mathrm{mbsf}$, detrital $\mathrm{K}$-feldspar, illite, mica, and plagioclase in hemipelagic and turbiditic sediment are hydrothermally altered to epidote, wairakite, albite, and quartz (Leybourne and Goodfellow, this volume). In some samples, intense epidotization has imparted a pale green color to the rock. Wairakite occurs in veins and vugs and interstitially within turbiditic silt and sand.

\section{GEOCHEMISTRY}

\section{Unaltered Sediment}

Chemical analyses of bulk sediment are given in Table 1 (located at the end of this chapter). Descriptive statistics for unaltered hemipelagic silt clay and turbiditic silt and clay are presented in Table 2. 


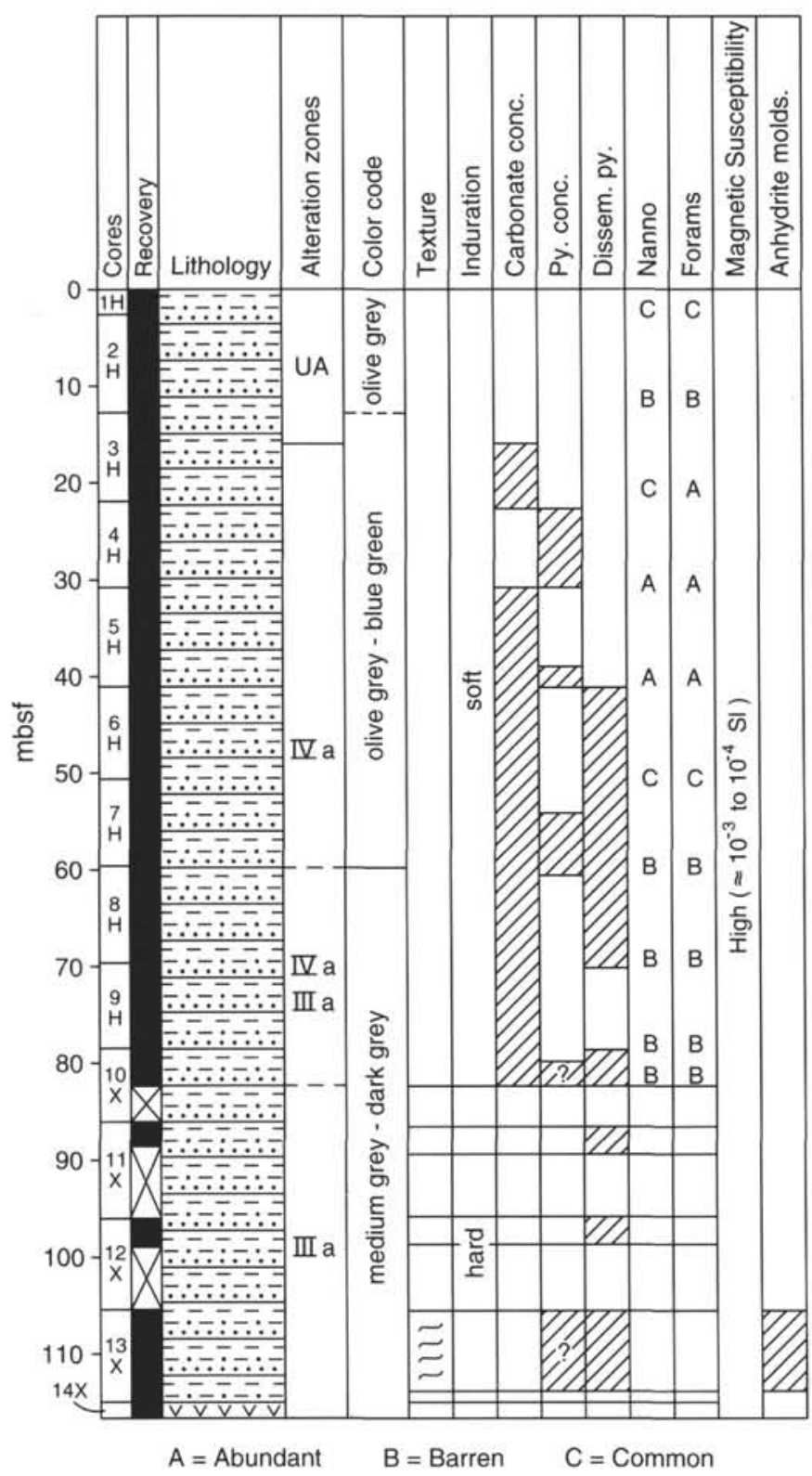

Figure 9. Stratigraphic section of Hole 856A showing the general sedimentology, structures, textures, hydrothermal minerals, and alteration zones.

The frequency distribution for some elements is skewed due to anomalously high contents of several transition metals in a few oxidized samples from the upper surface layer. Four broad element groups have been defined for Middle Valley regional hemipelagic and turbiditic sediment using R-mode factor analysis. Group 1 consists of $\mathrm{Al}_{2} \mathrm{O}_{3}, \mathrm{TiO}_{2}, \mathrm{Fe}_{2} \mathrm{O}_{3} \mathrm{~T}, \mathrm{MgO}, \mathrm{P}_{2} \mathrm{O}_{5}, \mathrm{~K}_{2} \mathrm{O}, \mathrm{Sr}, \mathrm{Rb}, \mathrm{Cr}, \mathrm{Nb}, \mathrm{La}$, and $\mathrm{Y}$. These elements reside in the detrital component of hemipelagic sediment that consists mostly of illite, muscovite, chlorite, titanite, and apatite. These elements display statistically significant covariations with correlation coefficients between 0.5 and 0.75 at the $95 \%$ confidence level. Group 2 consists of $\mathrm{SiO}_{2}, \mathrm{Al}_{2} \mathrm{O}_{3}, \mathrm{Na}_{2} \mathrm{O}, \mathrm{CaO}$ (noncarbonate), and $\mathrm{Zr}$. These elements are enriched in detrital quartz, feldspar, and zircon in turbiditic sand and silt. The bulk chemical composition of these sediments is, in part, controlled by the abundance of detrital minerals, which is dependent on the grain size and style of sedimentation. Sediment compositions vary over a spectrum from sand to clay because turbidites commonly fine upward into hemipelagic sediment. The control of detrital mineralogy on the bulk chemical composition is illustrated by plots of $\mathrm{Al}_{2} \mathrm{O}_{3}, \mathrm{~K}_{2} \mathrm{O}, \mathrm{MgO}$ and $\mathrm{Zr}$ vs. $\mathrm{SiO}_{2}$ for silty clay, sand, and silt (Fig. 15). Adownhole plot of $\mathrm{Si}$ :Al ratios (Fig. 16) effectively discriminates between turbiditic intervals characterized by high ratios and hemipelagic sediment characterized by low ratios. Within turbiditic units, ratios commonly increase upward as the proportion of clay minerals increases relative to detrital quartz.

Group 3 is represented by $\mathrm{CaO}, \mathrm{CO}_{2}, \mathrm{Sr}$, and $\mathrm{MnO}$ that occur mostly in foraminiferal carbonates. Group 4 elements include most of the transition metals (e.g., $\mathrm{Zn}, \mathrm{Cu}, \mathrm{Ni}, \mathrm{Co}, \mathrm{V}, \mathrm{Se}, \mathrm{As}, \mathrm{Sb}, \mathrm{Mn}$, and $\mathrm{Fe}$ ) that are enriched in the brown, oxidized surface layer. Organic $\mathrm{C}$ and $\mathrm{Ba}$ are also enriched in this surface layer. The transition metals either form $\mathrm{Fe}$ and $\mathrm{Mn}$ oxyhydroxides or are sorbed to the surfaces of these minerals. The positive correlation of most transition metals with organic $\mathrm{C}$ most likely reflects the high content of organic matter in the oxidized surface layer, and the coupled reactions of bacterial organic $\mathrm{C}$ oxidation and $\mathrm{Fe}$ reduction with depth during diagenesis (Berner, 1984; Goodfellow et al., 1993). The inverse correlation of $\mathrm{FeO}$ with $\mathrm{Fe}_{2} \mathrm{O}_{3}$ (Goodfellow et al., 1993) indicates that $\mathrm{Fe}^{3+}$ was reduced to $\mathrm{Fe}^{2+}$ during diagenesis. Elements sorbed onto oxyhydroxide surfaces and released to pore waters during the dissolution of $\mathrm{Fe}$ and Mn oxyhydroxides diffuse upwards and are partly resorbed to oxidized surface sediments, or are precipitated with diagenetic sulfides (Tsunogai et al., 1979; Berner, 1984).

Moreover, below the brown oxidized layer, most of the transition metals are more concentrated in silty clay than in coarser-grained turbidites due to the higher proportion of pelagic organic matter in the former. Most of the elements bound by organic matter were probably released to pore water by the bacterial oxidation of organic matter during diagenesis, and fixed as iron monosulfide by sulfide formed by the bacterial reduction of dissolved sulfate (Berner, 1984). Amorphous monosulfides are commonly converted to pyrite by reaction with bacteriogenic sulfide generated deeper in the sedimentary sequence.

\section{Hydrothermal Alteration}

\section{Bent Hill (Site 856)}

Downhole profiles of element abundances are used to illustrate the chemical variability within zones and chemical changes across alteration facies. These plots were constructed using the analyses in Table 1 (located at the end of this chapter) and in Davis, Mottl, Fisher, et al. (1992).

\section{Hole $856 B$}

Chemical profiles for Hole 856B are presented in Figures 17A, B, and $\mathrm{C}$. $\mathrm{SiO}_{2}, \mathrm{Al}_{2} \mathrm{O}_{3}$, and $\mathrm{TiO}_{2}$ fall within the range of unaltered hemipelagic sediment except between 18 and $25 \mathrm{mbsf}$, where massive sulfides occur, and below 110 mbsf in Zones Ia-1 and Ia-2, where $\mathrm{SiO}_{2}$ generally increases and $\mathrm{Al}_{2} \mathrm{O}_{3}$ and $\mathrm{TiO}_{2}$ decrease, due in part to the dilution effect of hydrothermal quartz. In general, $\mathrm{FeO}$ increases and $\mathrm{Fe}_{2} \mathrm{O}_{3}$ concomitantly decreases with depth due to the sulfidation of $\mathrm{Fe}$ in detrital magnetite and amphibole. The sulfidation of iron in detrital minerals is reflected by major increases of sulfide $\mathrm{S}$ and $\mathrm{Fe}^{2+}$ throughout Hole 856B. $\mathrm{Fe}_{2} \mathrm{O}_{3} \mathrm{~T}$ does not, however, increase except near the base of the hole where highly silicified sediment is cut by pyrrhotite and chalcopyrite veins. Zinc, Se, and Mo are elevated relative to unaltered sediment (Table 3 ) and are associated with high $\mathrm{Cu}$ values ( $>5000$ parts per million [ppm]) in Zone Ia-1. Arsenic, Sb, and $\mathrm{Be}$ are depleted relative to unaltered sediment (Table 3 ) in Zones Ia-1 and Ia-2.

Elements bound in biogenic carbonate, namely $\mathrm{CaO}, \mathrm{CO}_{2}$, and $\mathrm{Sr}$, decrease downhole to a depth of about $40 \mathrm{mbsf}$ and remain uniformly low to the bottom of the hole. $\mathrm{MgO}$, however, increases systematically to a depth of 108 mbsf, below which it decreases (Zone Ia-1) and then increases (Zone Ia-2). High MgO contents reflect Mg-rich chlorite in Zone IIIa and Mg-rich clay in Zone IVa (Leybourne and Goodfellow, this volume). Increases in $\mathrm{MgO}$ are accompanied by 


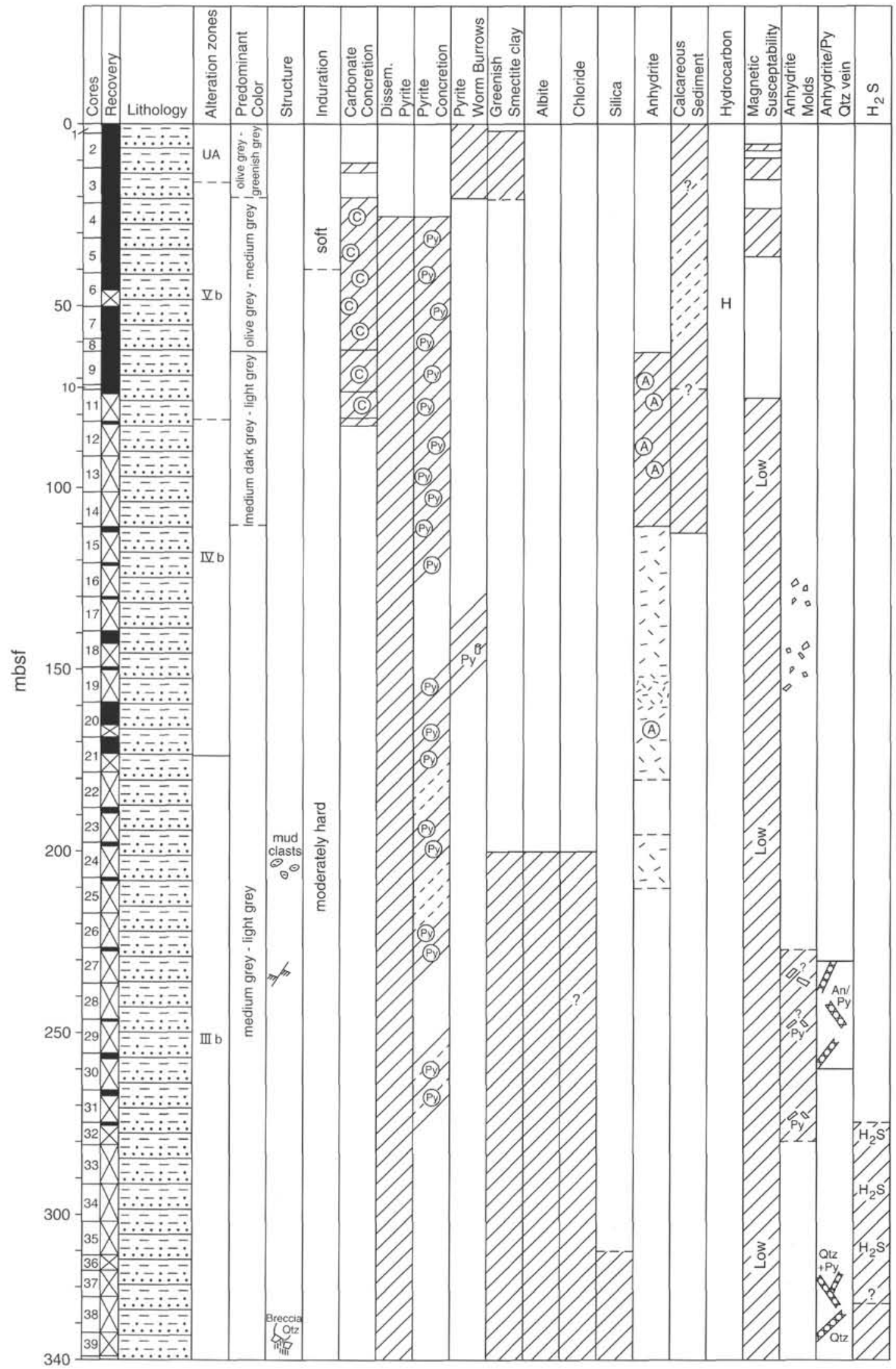

Figure 10. Stratigraphic section of Hole 858A showing the general sedimentology, structures, textures, alteration mineralogy, and alteration zones. 


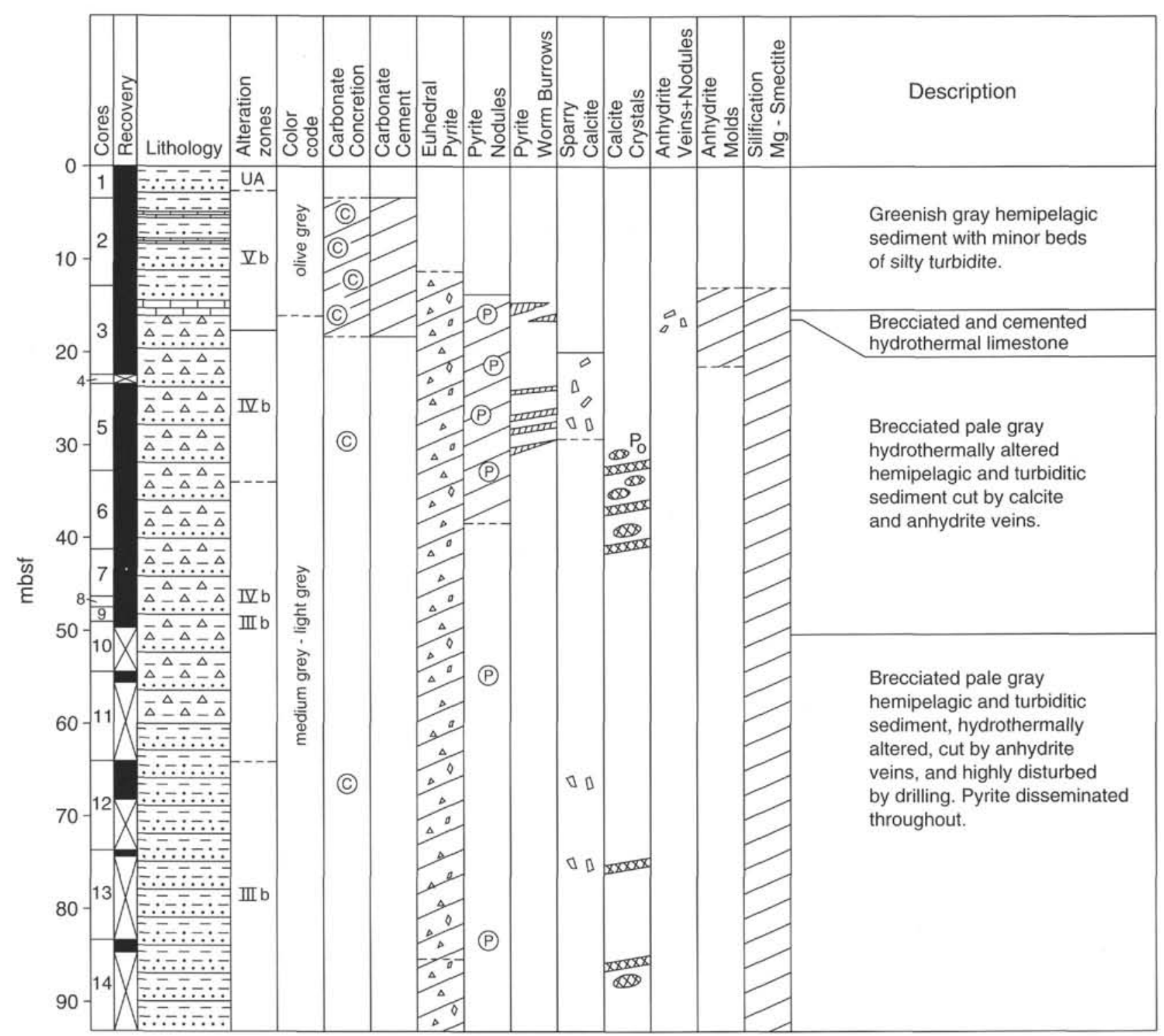

Figure 11. Stratigraphic section of Hole $858 \mathrm{C}$ showing the general sedimentology, structures, textures, alteration mineralogy, and alteration zones.

higher $\mathrm{H}_{2} \mathrm{O}$ contents because most of the $\mathrm{Mg}$ is bound by hydrated clays. $\mathrm{MnO}$, which is bound mostly in chlorite, reaches maximum values in Zone IIa. $\mathrm{Na}_{2} \mathrm{O}$ decreases steadily in Zone IIIa to a depth of $63 \mathrm{mbsf}$, except where bedded sulfides occur, and then increases in Zone IIa. $\mathrm{Na}_{2} \mathrm{O}$ decreases markedly in Zones Ia-1 and Ia-2. Low $\mathrm{Na}_{2} \mathrm{O}$ contents in Zone IIIa correspond to high $\mathrm{K}_{2} \mathrm{O}$ associated with illite alteration; high $\mathrm{Na}_{2} \mathrm{O}$ is due to the albitization of detrital plagioclase. Because $\mathrm{Ba}$ is a common minor element in $\mathrm{K}$-feldspar, the hydrothermal breakdown of feldspar in Zones Ia and IIa is reflected by a marked decrease in Ba below 65 mbsf.

Organic C decreases systematically with depth to values $<0.2$ weight percent (wt\%) within Zones IIa and Ia. This decrease is probably caused by the thermal catalysis of organic matter at high temperature (Simoneit, 1984). The occurrence of hydrothermal bitumen in barite chimneys from Middle Valley indicates that organic matter is cracked by hydrothermal fluids at temperatures in excess of $300^{\circ} \mathrm{C}$ (Simoneit et al., 1992). A ${ }^{14} \mathrm{C}$ age of $29,000 \mathrm{aBP}$ for this bitumen indicates that the source of carbon is immature sedimentary organic matter from shallow depths in the sedimentary sequence $(<12 \mathrm{~m}$ based on average sedimentation rates of $40 \mathrm{~cm} \mathrm{k.y.}{ }^{-1}$, per Goodfellow et al., 1993).

\section{Hole $856 \mathrm{~A}$}

Hemipelagic and turbiditic sediments in Hole 856A are less altered than similar sediments in Hole $856 \mathrm{~B}$. The contents of most elements generally fall within the range of unaltered turbiditic and hemipelagic sediments (Table 2). The large downhole variability of many of these elements (Figs. 18A, B, and C) is controlled by detrital sediment compositions (i.e., silt vs. silty clay) and the dilution effect of calcite concretions and cement in Zone IVa. The higher $\mathrm{CaO}$ and $\mathrm{CO}_{2}$ contents between 15 and $82 \mathrm{mbsf}$ (Zone IVa) are accompanied by higher $\mathrm{MgO}, \mathrm{H}_{2} \mathrm{O}$ and $\mathrm{S}$ contents because of the co-occurrence of Mg-rich smectite and pyrite. $\mathrm{Fe}_{2} \mathrm{O}_{3} \mathrm{~T}$ does not increase, although $\mathrm{Fe}^{2+} / \mathrm{Fe}^{3+}$ ratios and $\mathrm{S}$ increase systematically with depth due to the hydrothermal reduction and sulfidation of iron in magnetite and amphibole as in Hole 856B. Downhole variations of $\mathrm{MnO}, \mathrm{Cu}, \mathrm{As}, \mathrm{Sb}$, and Se are controlled mostly by sediment type, except in Zone IVa, where these elements are concentrated in carbonate concretions. The manganese substitutes for $\mathrm{Ca}$ in calcite whereas the chalcophile elements occur as sulfides in concretions. In unaltered sediment, the chalcophile elements form diagenetic sulfides, which are more abun- 


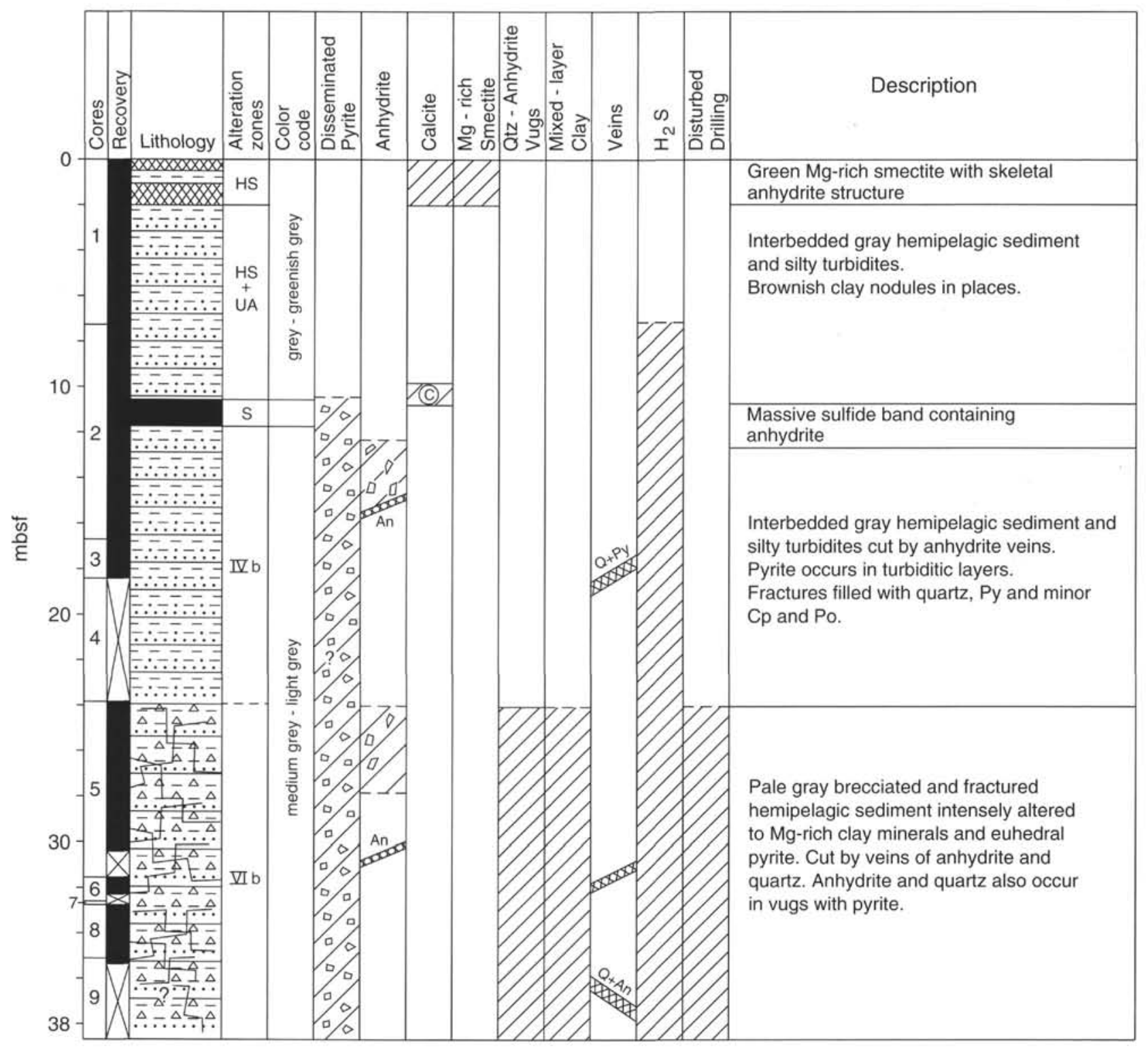

Figure 12. Stratigraphic section of Hole 858B showing the general sedimentology, structures, textures, alteration mineralogy, and alteration zones.

dant in hemipelagic sediment relative to turbiditic sediment as a result of higher contents of more readily metabolized organic matter and lower sedimentation rates.

\section{Area of Active Venting (Site 858) \\ Hole $858 \mathrm{~A}$}

Hole $858 \mathrm{~A}$ intersects unaltered hemipelagic sediment through alteration Zones $\mathrm{Vb}, \mathrm{IVb}$, and IIIb towards the center of hydrothermalfluid upflow at Site 858 (Fig. 5). $\mathrm{CaO}, \mathrm{CO}_{2}$ and $\mathrm{MnO}$ display erratic increases in Zone $\mathrm{Vb}$ due to the presence of calcite concretions and cement (Figs. 19A, B, and C) and decrease downhole in Zone IVb. FeO and $\mathrm{Fe}_{2} \mathrm{O}_{3}$ behave antithetically with depth due to the reduction and sulfidation of iron bound in magnetite and other detrital minerals such as amphiboles, epidote, and chlorite. The sulfidation of iron is reflected by an increase in pyrite and sulfide $\mathrm{S}$ in all alteration zones in Hole $858 \mathrm{~A}$. $\mathrm{Fe}_{2} \mathrm{O}_{3} \mathrm{~T}$ falls within the range of unaltered sediments and indicates minimal $\mathrm{Fe}$ addition by hydrothermal processes.

$\mathrm{MgO}$ contents are within the range of values for unaltered sediment (Table 2) from 0 to $120 \mathrm{mbsf}$ and exceed values for unaltered sediment between 120 and 300 mbsf. High MgO contents correspond to the alteration of K-feldspar and mica by saponite in Zone IVb, and by $\mathrm{Mg}$-rich chlorite in Zone IIIb. This replacement of saponite and chlorite results in an inverse correlation between $\mathrm{MgO}$ and $\mathrm{K}_{2} \mathrm{O}$ with depth in Hole $858 \mathrm{~A}$. $\mathrm{H}_{2} \mathrm{O}$ (T) covaries with $\mathrm{MgO}$ because of the occurrence of hydrated silicates such as Mg-smectite in Zones IVb and IIIb. $\mathrm{High} \mathrm{Na}_{2} \mathrm{O}$ contents between 190 and 300 mbsf are controlled by the albitization of plagioclase in Zone IIIb (Leybourne and Goodfellow, this volume).

Barium abundances in saponitic sediment near the seafloor and within Zone VIb exceed those in unaltered sediment (Table 3). Between 75 and 300 mbsf (Fig. 19), Ba decreases relative to unaltered sediment due to the chloritization of K-feldspar and muscovite. Strontium decreases with depth between 0 and 50 mbsf to less than 200 $\mathrm{ppm}$, except for several anomalously high values between 50 and 300 mbsf. Low $\mathrm{Sr}$ contents below $50 \mathrm{mbsf}$ are due to the hydrothermal dissolution of foraminifers. The hydrothermal destruction of microorganisms is also reflected by lower organic C contents in Zone IIIb (Fig. 19). Arsenic, Sb, and Se contents are erratic but are generally elevated relative to unaltered sediments throughout Hole 858 A (Table 
GEOCHEMISTRY OF HYDROTHERMALLY ALTERED SEDIMENT

2). The highest abundances of these elements occur in saponitic sediment near the seafloor and in alteration Zone $\mathrm{Vb}$. Most of the remaining elements fall within the range of hemipelagic and turbiditic sediments (Table 3), except where sedimentary minerals have been significantly diluted by hydrothermal carbonate in Zone $\mathrm{Vb}$.

\section{Hole $858 B$}

$\mathrm{MgO}, \mathrm{MnO}$, and Mo contents increase downhole (up to $30 \mathrm{wt} \%$ $\mathrm{MgO}$ at $28 \mathrm{mbsf}$ ), whereas $\mathrm{Na}_{2} \mathrm{O}, \mathrm{K}_{2} \mathrm{O}, \mathrm{CaO}, \mathrm{CO}_{2}, \mathrm{Sr}, \mathrm{Rb}$, and $\mathrm{Ba}$ decrease with depth (Figs. 20A, B, and C). Most of these chemical changes reflect the formation of saponite at the expense of detrital feldspar and mica and the hydrothermal dissolution of biogenic carbonate. The marked decrease of lithophile element contents between 10 and 14 mbsf reflects the dilution of detrital minerals by sulfides and anhydrite. Below 14 mbsf $\mathrm{SiO}_{2}, \mathrm{TiO}_{2}, \mathrm{Al}_{2} \mathrm{O}_{3}, \mathrm{Be}, \mathrm{Co}$, and $\mathrm{V}$ decrease slightly with depth, probably due to dilution by hydrothermal saponite. The chalcophile elements $\mathrm{Cu}, \mathrm{Pb}, \mathrm{Zn}, \mathrm{Ag}, \mathrm{As}, \mathrm{Sb}$, and Se are highly enriched in the sulphide-anhydrite bed; these elements are generally elevated relative to unaltered sediment throughout most of Hole 858B (Fig. 20).

\section{Hole $858 \mathrm{C}$}

The addition of hydrothermal calcite in Zone $\mathrm{Vb}$ is reflected, in part, by marked increases of $\mathrm{CaO}, \mathrm{CO}_{2}, \mathrm{MnO}, \mathrm{Ba}, \mathrm{Zn}, \mathrm{As}, \mathrm{Sb}, \mathrm{Pb}, \mathrm{Se}$, and Mo (Figs. 21A, B, and C), and decreases in lithophile elements due to dilution. The chalcophile elements and $\mathrm{Ba}$ form sulfides and barite, respectively, that coexist with hydrothermal carbonate. Below Zone $\mathrm{Vb}$ to a depth of $76 \mathrm{mbsf}$ the $\mathrm{SiO}_{2}$ content is generally greater than for unaltered hemipelagic sediment, whereas $\mathrm{Al}_{2} \mathrm{O}_{3}, \mathrm{TiO}_{2}$, and $\mathrm{Fe}_{2} \mathrm{O}_{3} \mathrm{~T}$ fall within the range for unaltered sediment (Table 2; Fig. 21A). This $\mathrm{SiO}_{2}$ increase corresponds to quartz precipitated from hydrothermal fluids. The increase of $\mathrm{FeO}$ and decrease of $\mathrm{Fe}_{2} \mathrm{O}_{3}$ with depth results from the reduction of iron and the formation of hydrothermal pyrite (as in Hole 858A). The formation of pyrite is reflected by high contents of reduced $\mathrm{S}$ in all alteration zones in Hole $858 \mathrm{C}$ (Fig. 21).

The $\mathrm{K}_{2} \mathrm{O}$ and $\mathrm{Rb}$ contents are erratic in Zone $\mathrm{IVb}$ between 18 and $45 \mathrm{mbsf}$, but they generally exceed values for unaltered hemipelagic sediment, whereas $\mathrm{Na}_{2} \mathrm{O}$ contents are generally lower than for unaltered sediment (Table 3). $\mathrm{MgO}$ increases with depth within Zone $\mathrm{Vb}$ and is also high in the underlying Zone IIIb. The antithetic behavior of $\mathrm{MgO}$ and $\mathrm{K}_{2} \mathrm{O}$ with depth is governed by the hydrothermal replacement of $\mathrm{K}$-feldspar and $\mathrm{K}$-mica by chlorite and saponite. $\mathrm{CaO}$ contents range between 2 and $5 \mathrm{wt} \%$ in $\mathrm{Zone} \mathrm{Vb}$ and decrease to values below $2 \mathrm{wt} \%$ in Zone IIIb. $\mathrm{CO}_{2}$ contents approach zero and $\mathrm{Sr}$ decreases to less than $200 \mathrm{ppm}$ at depths greater than $18 \mathrm{mbsf}$ because of the hydrothermal dissolution of biogenic carbonate, except for isolated high values that coincide with the presence of calcite and anhydrite veins (Fig. 12). The decrease of $\mathrm{CaO}$ in Zone IIIb results from the combined effects of calcite dissolution and albitization of detrital plagioclase (Leybourne and Goodfellow, this volume).

Arsenic, $\mathrm{Sb}$ and Se contents are highly erratic and are generally enriched relative to unaltered hemipelagic and turbiditic sediments at depths between 18 and 78 mbsf in Zones IVb and IIIb (Table 3). Abundances of the remaining elements fall within the range for unaltered hemipelagic and turbiditic sediment, except for sediment samples that have been diluted by additions of hydrothermal minerals in veins and in the massive carbonate-cemented zone.

\section{Holes $858 D$ and $858 F$}

$\mathrm{SiO}_{2}$ contents increase with depth to $>70 \mathrm{wt} \%$ at $49 \mathrm{mbsf}$ and are above average values for hemipelagic sediment to a depth of $230 \mathrm{mbsf}$ (except for one pyrite vein at $132.9 \mathrm{mbsf}$ ) (Fig. 22A). Near the base of the hole at about $250 \mathrm{mbsf}, \mathrm{SiO}_{2}$ contents are typical of unaltered
Table 2. Summary statistics for bulk chemical data for unaltered hemipelagic and turbiditic sediments, Holes $857 \mathrm{~A}, 855 \mathrm{~A}, 855 \mathrm{~B}$, and $855 \mathrm{C}$.

\begin{tabular}{|c|c|c|c|c|c|c|c|c|c|c|}
\hline \multirow[b]{2}{*}{ Wt\%: } & \multicolumn{5}{|c|}{ Silty claystones $(n=43)$} & \multicolumn{5}{|c|}{ Sand and silt $(\mathrm{n}=23)$} \\
\hline & Mean & Med & Min & $\operatorname{Max}$ & c.V. & Mean & Med & Min & Max & C.V. \\
\hline $\mathrm{SiO}_{2}$ & 53.6 & 54.1 & 49.0 & 55.9 & 0.035 & 60.8 & 60.4 & 58.1 & 65.2 & 0.04 \\
\hline $\mathrm{TiO}_{2}$ & 0.84 & 0.81 & 0.63 & 0.97 & 0.08 & 50.8 & 0.83 & 0.71 & 0.93 & 0.063 \\
\hline $\mathrm{Al}_{2} \mathrm{O}_{3}$ & 15.8 & 15.9 & 12.6 & 17.7 & 0.062 & 15.1 & 15.0 & 13.4 & 16.8 & 0.06 \\
\hline $\mathrm{Fe}_{2} \mathrm{O}_{3}{ }_{3} \mathrm{~T}$ & 7.90 & 7.80 & 6.70 & 11.8 & 0.113 & 6.41 & 6.50 & 4.90 & 8.50 & 0.13 \\
\hline $\mathrm{Fe}_{2} \mathrm{O}_{3}$ & 3.05 & 3.10 & 1.70 & 5.30 & 0.486 & 3.03 & 3.10 & 1.70 & 5.30 & 0.22 \\
\hline $\mathrm{FeO}$ & 4.22 & 4.15 & 3.20 & 5.60 & 0.460 & 4.32 & 4.20 & 3.20 & 7.60 & 0.21 \\
\hline $\mathrm{MnO}$ & 0.12 & 0.12 & 0.09 & 0.21 & 0.207 & 0.09 & 0.09 & 0.07 & 0.12 & 0.19 \\
\hline $\mathrm{MgO}$ & 3.88 & 3.84 & 3.12 & 4.70 & 0.105 & 3.10 & 3.12 & 2.21 & 4.08 & 0.16 \\
\hline $\mathrm{CaO}$ & 4.78 & 4.19 & 2.70 & 8.83 & 0.355 & 3.98 & 4.06 & 2.35 & 5.26 & 0.17 \\
\hline $\mathrm{Na}_{2} \mathrm{O}$ & 2,24 & 2.22 & 1.12 & 3.50 & 0.136 & 2.82 & 2.87 & 2.09 & 3.51 & 0.19 \\
\hline $\mathrm{K}_{2} \mathrm{O}$ & 2.16 & 2.20 & 1.81 & 2.91 & 0.114 & 1.86 & 1.78 & 1.34 & 2.71 & 0.20 \\
\hline $\mathrm{H}_{2}^{2} \mathrm{O}^{\mathrm{T}}$ & 4.20 & 4.30 & 2.50 & 5.67 & 0.175 & 3.01 & 3.10 & 1.70 & 4.36 & 0.27 \\
\hline $\mathrm{P}_{2} \mathrm{O}_{5}$ & 0.19 & 0.19 & 0.13 & 0.24 & 0.108 & 0.20 & 0.19 & 0.16 & 0.22 & 0.08 \\
\hline $\mathrm{S}$ & 0.27 & 0.20 & 0.08 & 0.94 & 0.64 & 0.28 & 0.20 & 0.08 & 0.94 & 0.20 \\
\hline $\mathrm{CO}_{2}$ & 1.60 & 0.90 & 0.10 & 4.30 & 0.73 & 1.60 & 1.20 & 0.10 & 4.30 & 0.73 \\
\hline $\begin{array}{l}\text { C-org } \\
(\mathrm{ppm})\end{array}$ & 0.39 & 0.40 & 0.20 & 0.70 & 0.20 & 0.30 & 0.30 & 0.10 & 0.73 & 0.30 \\
\hline $\mathrm{Ba}$ & 709 & 705 & 470 & 130 & 0.20 & 593 & 564 & 410 & 950 & 0.21 \\
\hline $\mathrm{Be}$ & 1.33 & 1.40 & 1.20 & .80 & 0.12 & 1.41 & 1.40 & 0.70 & 1.80 & 1.40 \\
\hline Co & 22 & 23 & 16 & 29 & 0.16 & 24 & 24 & 16 & 49 & 0.23 \\
\hline $\mathrm{Cr}$ & 83 & 82 & 53 & 110 & 0.13 & 88 & 86 & 68 & 111 & 0.14 \\
\hline $\mathrm{Cu}$ & 55 & 55 & 40 & 75 & 0.12 & 36 & 38 & 20 & 50 & 0.24 \\
\hline $\mathrm{La}$ & 17 & 17 & 13 & 27 & 0.19 & 18 & 17 & 13 & 27 & 0.19 \\
\hline $\mathrm{Nb}$ & ii & 11 & 5 & 16 & 0.14 & 12 & 11 & 7 & 18 & 0.22 \\
\hline $\mathrm{Ni}$ & 58 & 57 & 42 & 76 & 0.15 & 45 & 48 & 28 & 63 & 0.96 \\
\hline $\mathrm{Rb}$ & 71 & 70 & 50 & 110 & 0.19 & 58 & 56 & 30 & 157 & 0.44 \\
\hline $\mathrm{Se}$ & 16 & 17 & 13 & 20 & 0.10 & 18 & 18 & 13 & 35 & 0.19 \\
\hline $\mathrm{Sr}$ & 343 & 338 & 236 & 480 & 0.17 & 350 & 350 & 222 & 440 & 0.18 \\
\hline v & 138 & 140 & 100 & 199 & 0.09 & 128 & 130 & 100 & 168 & 0.16 \\
\hline$Y$ & 20 & 20 & 17 & 24 & 0.07 & 20 & 20 & 17 & 25 & 0.11 \\
\hline $\mathrm{Yb}$ & 1.74 & 1.90 & 1.6 & 2.2 & 0.09 & 1.93 & 1.90 & 1.60 & 3.80 & 0.19 \\
\hline $\mathrm{Zn}$ & 119 & 110 & 91 & 420 & 0.47 & 82 & 83 & 49 & 122 & 0.24 \\
\hline $\mathrm{Zr}$ & 118 & 120 & 83 & 191 & 0.13 & 172 & 169 & 130 & 270 & 0.18 \\
\hline $\mathrm{Se}$ & 0.69 & 0.89 & 0.40 & 2.76 & 0.51 & 0.54 & 0.50 & 0.10 & 1.24 & 0.63 \\
\hline $\mathrm{Sb}$ & 5.73 & 0.64 & 0.24 & 1.31 & 0.41 & 0.40 & 0.35 & 0.21 & 0.67 & 0.36 \\
\hline As & 1.01 & 4.97 & 2.39 & 13.9 & 0.41 & 7.02 & 7.03 & 3.27 & 15.3 & 0.37 \\
\hline
\end{tabular}

Note: med $=$ median; $C . V .=$ coefficient of variation; $w t \%=$ weight percent; $\mathrm{ppm}=$ parts per million; $\mathrm{FeO}_{3} \mathrm{~T}=$ total iron expressed as $\mathrm{Fe}_{2} \mathrm{O}_{3} ; \mathrm{H}_{2} \mathrm{O}^{\top}=$ total water content of the sample after drying of the sample.

hemipelagic and turbiditic sediment (Table 2). $\mathrm{Al}_{2} \mathrm{O}_{3}, \mathrm{Fe}_{2} \mathrm{O}_{3} \mathrm{~T}, \mathrm{P}_{2} \mathrm{O}_{5}$, and $\mathrm{TiO}_{2}$ contents of most samples between 49 and 129 mbsf are less than those for unaltered hemipelagic sediment because of the dilution effect of hydrothermal quartz. Ferric $\mathrm{Fe}$ (expressed as $\mathrm{Fe}_{2} \mathrm{O}_{3}$ ) decreases with depth to $<0.2 \mathrm{wt} \%$ at $22.6 \mathrm{mbsf}$, remains low between 22.6 and $114.0 \mathrm{mbsf}$ and increases slightly between 114 and $249.6 \mathrm{mbsf}$.

$\mathrm{Na}_{2} \mathrm{O}$ contents decrease to $<1.0 \mathrm{wt} \%$ at $28 \mathrm{mbsf}$ and remain low to 110 mbsf (Zones IVb and Ib) (Fig. 22A). $\mathrm{Na}_{2} \mathrm{O}$ values increase below $110 \mathrm{mbsf}$ (Zone IIb) because of the albitization of detrital plagioclase (Leybourne and Goodfellow, this volume). The low $\mathrm{Na}_{2} \mathrm{O}$ contents in Zone $\mathrm{Ib}$ result from the replacement of albite by $\mathrm{Ca}$-plagioclase and wairakite. $\mathrm{CaO}$ decreases downhole within Zone $\mathrm{IVb}$ due to the hydrothermal dissolution of biogenic carbonate. Below Zone IVb, $\mathrm{CaO}$ behaves inversely to $\mathrm{Na}_{2} \mathrm{O}$ due to the replacement of albite by Ca-plagioclase and wairakite in Zone $\mathrm{Ib}$. $\mathrm{MgO}$ contents increase with depth in Zones $\mathrm{Vb}$ and $\mathrm{IVb}$ due to the formation of $\mathrm{Mg}$-rich clay minerals and are greater than for unaltered sediment in Zone IIb. In Zone Ib, however, the $\mathrm{MgO}$ content is generally less than in unaltered sediments.

$\mathrm{K}_{2} \mathrm{O}$ increases with depth in Zone $\mathrm{Vb}$ and is uniformly high in Zone $\mathrm{IVb}$ as a result of the formation of mixed layer illite-smectite. The marked decrease of $\mathrm{K}_{2} \mathrm{O}$ to $<1.0 \mathrm{wt} \%$ at depths $>30 \mathrm{mbsf}$ is governed by the hydrothermal alteration of $\mathrm{K}$-feldspar and mica to chlorite, plagioclase, and wairakite. $\mathrm{Rb}, \mathrm{Ba}, \mathrm{CO}_{2}, \mathrm{Cu}, \mathrm{Zn}, \mathrm{As}, \mathrm{Sb}, \mathrm{Se}$, and $\mathrm{Sr}$ also decrease markedly below $28 \mathrm{mbsf}$. Above $28 \mathrm{mbsf}$ within Zone $\mathrm{IVb}$ there is a major increase in $\mathrm{Zn}, \mathrm{Ba}, \mathrm{As}, \mathrm{Sb}, \mathrm{Se}, \mathrm{Mo}$, and $\mathrm{S}$ (Fig. 22B). Nickel and V contents are highly variable with depth, but these elements generally covary (Fig. 22B).

\section{Hydrothermal Reaction Zone (Site 857)}

The downhole chemical variations in Holes 857A, 857C, and 857D are presented in Figures $23 \mathrm{~A}, \mathrm{~B}$, and $\mathrm{C} . \mathrm{SiO}_{2}$ generally ranges between 50 and $70 \mathrm{wt} \%$, except for samples with carbonate concretions where 
Figure 13. Stratigraphic section of Hole $857 \mathrm{C}$ showing the general sedimentology, structures, textures, alteration mineralogy, and alteration zones.

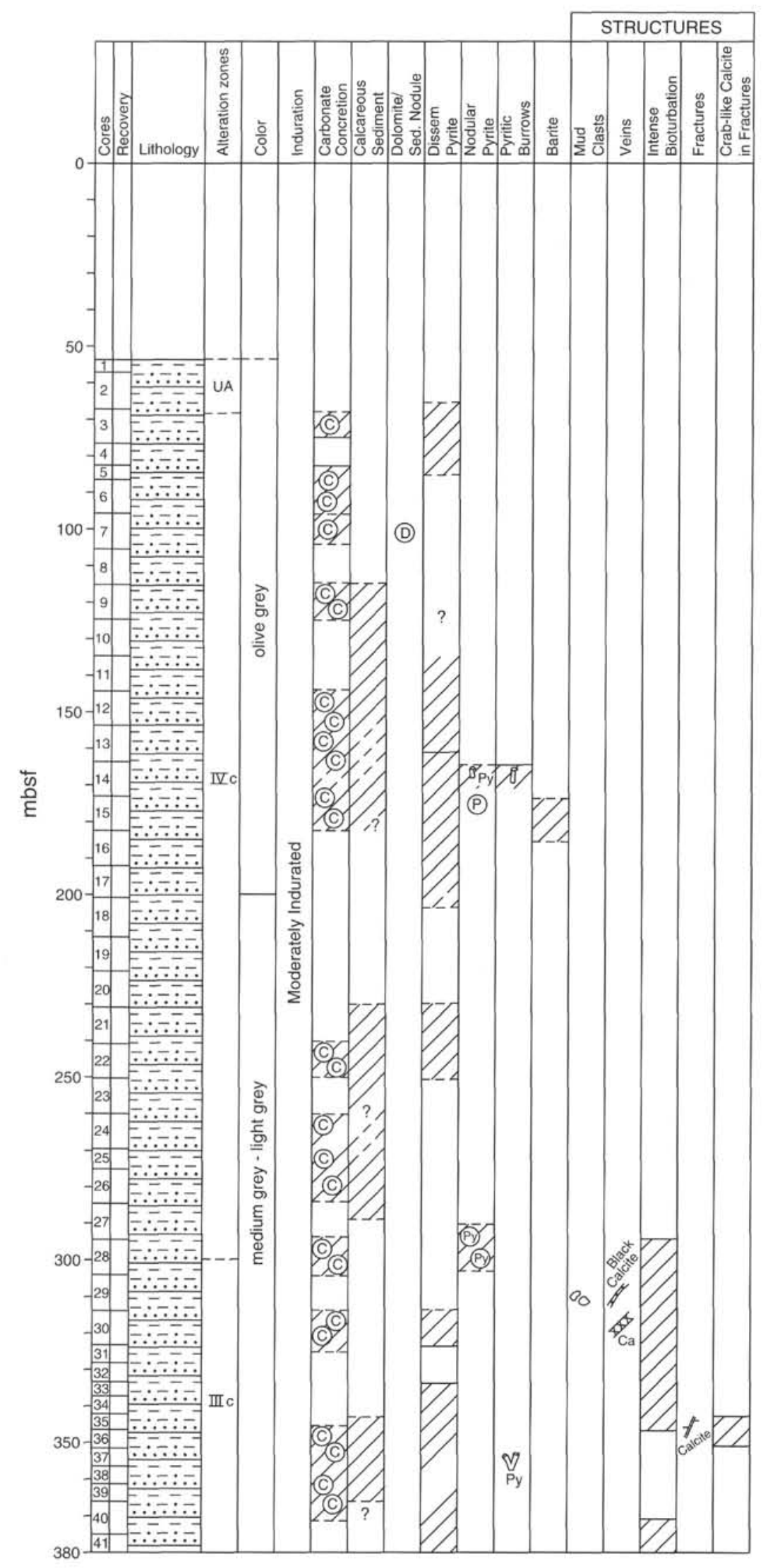




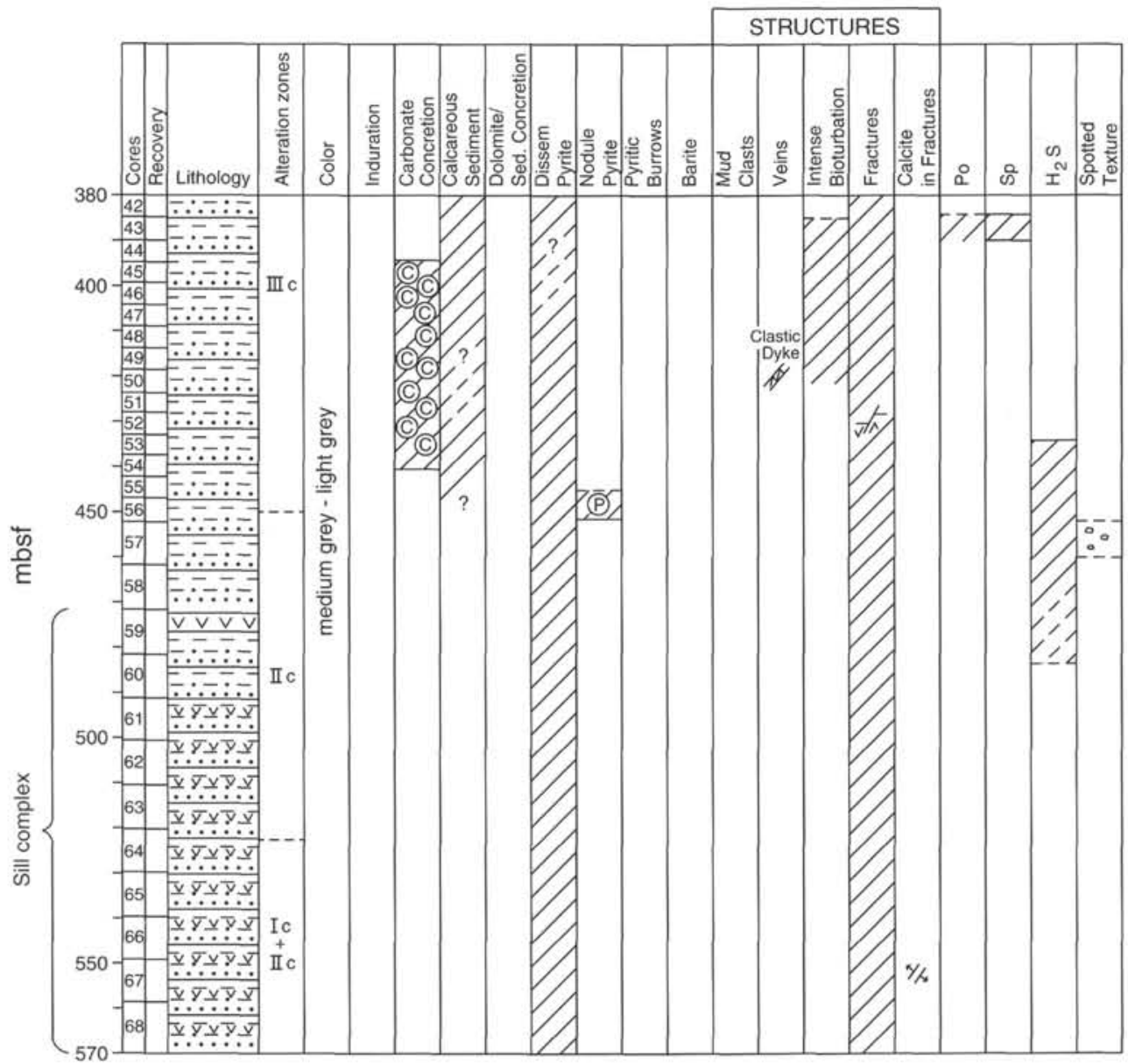

Figure 13 (continued).

the silica content is diluted by calcite and dolomite. Below about 550 mbsf in Holes $857 \mathrm{C}$ and $857 \mathrm{D}$ (Zones Ic and IIc), $\mathrm{SiO}_{2}$ increases to values $>70 \mathrm{wt} \%$ because of the addition of hydrothermal quartz, with a concomitant decrease of $\mathrm{TiO}_{2}, \mathrm{Al}_{2} \mathrm{O}_{3}, \mathrm{Fe}_{2} \mathrm{O}_{3} \mathrm{~T}, \mathrm{MgO}, \mathrm{P}_{2} \mathrm{O}_{5}, \mathrm{La}, \mathrm{Zr}, \mathrm{Cr}$, $\mathrm{Co}, \mathrm{V}$, and $\mathrm{Y}$ (except for carbonate concretions). $\mathrm{TiO}_{2}$ values $>1.5 \mathrm{wt} \%$ at 539.0 and $539.7 \mathrm{mbsf}$ are from samples that are mixtures of mafic sill and sediment. $\mathrm{TiO}_{2} / \mathrm{Al}_{2} \mathrm{O}_{3}$ ratios are relatively uniform and are similar to those for unaltered hemipelagic and turbiditic sediment except locally below $550 \mathrm{mbsf}$ (Fig. 23A), where erratic fluctuations of this ratio suggest that $\mathrm{Al}$ and/or $\mathrm{Ti}$ have been locally mobilized during hydrothermal alteration.

$\mathrm{Na}_{2} \mathrm{O}$ contents increase downhole to a depth of $250 \mathrm{mbsf}$, remain high to about $500 \mathrm{mbsf}$ (Zone IIIc), and decrease from about 500 to 700 mbsf. Below $700 \mathrm{mbsf} \mathrm{Na}_{2} \mathrm{O}$ increases to $>3.0 \mathrm{wt} \%$ to the bottom of Hole 857D. The high $\mathrm{Na}_{2} \mathrm{O}$ contents between 240 and 500 mbsf coincide with the albitization of detrital plagioclase (Leybourne and Goodfellow, this volume) and low Na values of pore water (Davis, Mottl, Fisher, et al., 1992). The low Sr contents between 220 and 405 mbsf probably reflect the albitization of detrital calcic plagioclase.

Below 430 mbsf $\mathrm{K}_{2} \mathrm{O}$ decreases to $<0.06 \mathrm{wt} \%$ because of the replacement of $\mathrm{K}$-feldspar, illite, and detrital mica by epidote, quartz, wairakite, and albite. Rubidium, $\mathrm{Ba}, \mathrm{Zn}, \mathrm{Cu}, \mathrm{Be}, \mathrm{As}, \mathrm{Sb}$, and $\mathrm{Se}$ also display a marked decrease due to the hydrothermal alteration of sedimentary minerals (Fig. 23B). CaO generally decreases to a depth of $320 \mathrm{mbsf}$ due to dissolution of biogenic carbonates, and below this increases erratically to the bottom of Hole 857D. High $\mathrm{CaO}$ contents above $500 \mathrm{mbsf}$ correspond to carbonate concretions, whereas below this depth the $\mathrm{CaO}$ occurs in wairakite and epidote. Below $500 \mathrm{mbsf}$ $\mathrm{CO}_{2}$ is $<1.0 \mathrm{wt} \%$ because of the hydrothermal dissolution of carbon- ate. Sulfur contents are generally $<0.5 \mathrm{wt} \%$ at depths between 500 and $615 \mathrm{mbsf}$, except for isolated high values (Fig. 23), approach $2 \mathrm{wt} \%$ between 615 and $735 \mathrm{mbsf}$ due to the presence of pyrite and pyrrhotite veins, and are generally less than values for unaltered sediments ( $\approx 0.36$ wt $\%$; Table 3 ) below 735 mbsf.

\section{MASS BALANCE CALCULATIONS}

Mass changes were calculated using the equation of Gresens (1967) to evaluate absolute chemical changes during hydrothermal alteration of sediments:

$$
X_{n}=W_{B}-W_{A}=w\left\{\left[\left(F_{v}\right)\left(X_{B}\right) S_{B} / S_{A}\right]-X_{A}\right\},
$$

where $X_{n}$ is the change in weight proportion of component $n, W_{A}$ and $W_{B}$ are the weights of components $n$ in parent rock $A$ and altered rock $B$, respectively, $w$ is the initial weight of parent rock, $F_{v}$ is the volume factor (the ratio of volume of altered rock to parent rock), $X_{A}$ and $X_{B}$ are the weight proportions of component $n$ in parent rock $A$ and altered rock $B$, respectively, and $S_{A}$ and $S_{B}$ are specific gravities of parent and altered rocks, respectively.

As suggested by Leitch and Day (1990), by expressing $X_{n}^{I}$ as the $W_{B} / I W_{A}$ ratio, Equation 1 is dimensionless, and solving the logarithm of this ratio results in a linear relationship between $X_{n}^{l}$ and $F_{v}$ :

$$
\log \left(X^{l}{ }_{n}\right)=\log \left(W_{B} / W_{A}\right)=\log \left(F_{v}\right)+\log \left[\left(X_{B} / X_{A}\right)-\left(S_{B} / S_{A}\right)\right] .
$$

Because there are two unknowns in Equation 2, namely $X_{n}^{1}$ and $F_{v}$, it is possible to determine the relative mobility of elements by choosing values of $\log F_{v}$ and plotting them against $\log X_{n}^{I}$ for each sample. Immobile constituents will have common intercepts on $\log F_{v}$. Because 
Table 3. Average composition of hydrothermally altered sediments associated with the BH (Site 856) and AAV (Site 858) fluid upflow zones, and the hydrothermal reaction zone at Site 857.

\begin{tabular}{|c|c|c|c|c|c|c|c|c|c|c|c|c|c|}
\hline \multirow[b]{2}{*}{ Wt $\%$ : } & \multicolumn{5}{|c|}{$\begin{array}{l}\text { Bent Hill (Site 856) } \\
\text { alteration zones }\end{array}$} & \multicolumn{6}{|c|}{$\begin{array}{l}\text { AAV (Site 857) } \\
\text { alteration zone }\end{array}$} & \multirow{2}{*}{$\begin{array}{c}\begin{array}{c}\text { Site } 857 \\
\text { alteration } \\
\text { zone }\end{array} \\
\text { Ic }\end{array}$} & \multirow{2}{*}{$\begin{array}{r}\text { Hole } 857 \\
\text { Unaltered }\end{array}$} \\
\hline & Ia-1 & la-2 & IIa & IIIIa & IVa & $\mathrm{Ib}$ & $\mathrm{Ilb}$ & IIIIb & $\mathrm{IVb}$ & $\mathrm{Vb}$ & VIb & & \\
\hline $\mathrm{SiO}_{2}$ & 54.5 & 61.3 & 61.1 & 54.3 & 56.2 & 67.5 & 58.4 & 58.7 & 57.4 & 51.8 & 41.9 & 63.3 & 55.85 \\
\hline $\mathrm{TiO}_{2}^{2}$ & 0.78 & 0.71 & 0.79 & 0.79 & 0.78 & 0.53 & 0.87 & 0.81 & 0.78 & 0.70 & 0.60 & 0.76 & 0.82 \\
\hline $\mathrm{Al}_{2} \mathrm{O}_{3}$ & 15.1 & 12.9 & 14.9 & 14.8 & 14.5 & 14.2 & 15.8 & 15.0 & 15.1 & 13.4 & 11.2 & 13.6 & 14.9 \\
\hline $\mathrm{Fe}_{2} \mathrm{O}_{3}^{3} \mathrm{~T}$ & 10.8 & 14.3 & 5.91 & 8.00 & 6.5 & 2.93 & 7.37 & 6.73 & 7.00 & 6.00 & 4.89 & 7.11 & 7.20 \\
\hline $\mathrm{MnO}^{2}$ & 0.13 & 0.21 & 0.34 & 0.10 & 0.16 & 0.43 & 0.13 & 0.15 & 0.11 & 0.15 & 0.21 & 0.14 & 0.13 \\
\hline $\mathrm{MgO}$ & 6.22 & 3.45 & 6.80 & 6.37 & 4.27 & 2.07 & 6.73 & 5.45 & 5.79 & 2.82 & 29.6 & 4.03 & 3.82 \\
\hline $\mathrm{CaO}$ & 1.59 & 0.25 & 0.45 & 0.41 & 5.37 & 5.02 & 1.90 & 2.73 & 1.94 & 9.23 & 1.54 & 4.71 & 4.76 \\
\hline $\mathrm{Na}_{2} \mathrm{O}$ & 0.43 & 0.08 & 2.93 & 1.31 & 2.46 & 2.43 & 4.13 & 3.72 & 2.33 & 1.68 & 0.68 & 2.67 & 2.34 \\
\hline $\mathrm{K}_{2} \mathrm{O}$ & 1.34 & 1.32 & 0.89 & 2.31 & 1.83 & 0.14 & 0.38 & 2.25 & 2.34 & 2.91 & 0.10 & 0.05 & 2.02 \\
\hline $\mathrm{H}_{2} \mathrm{O}^{\top}$ & 2.81 & 1.50 & 2.53 & 3.71 & 3.14 & 2.90 & 4.22 & 5.30 & 4.93 & 3.86 & 11.2 & 3.13 & 3.69 \\
\hline $\mathrm{P}_{2} \mathrm{O}_{5}$ & 0.15 & 0.15 & 0.21 & 0.19 & 0.22 & 0.15 & 0.21 & 0.20 & 0.20 & 0.20 & 0.04 & 0.17 & 0.20 \\
\hline $\mathrm{s}^{2-3}$ & 1.66 & 2.31 & 1.20 & 1.66 & 0.06 & 0.64 & 0.94 & 1.64 & 1.64 & 1.08 & 0.82 & 0.58 & 0.36 \\
\hline $\mathrm{CO}_{2}$ & 0.0 & .009 & .006 & 0.06 & 2.78 & 0.0 & 0.0 & 0.05 & 0.48 & 4.19 & 0.09 & 0.05 & 2.31 \\
\hline C-org & 0.06 & 0.08 & 0.08 & 0.28 & 0.24 & 0.0 & 0.09 & 0.19 & 0.24 & 0.27 & 0.17 & 0.03 & 0.37 \\
\hline $\begin{array}{l}\text { (ppm) } \\
\mathrm{Ba}\end{array}$ & 416 & 427 & 120 & 572 & 504 & 63 & 150 & 204 & 642 & 869 & 55 & 0.63 & 600 \\
\hline $\mathrm{Be}$ & 0.66 & 0.34 & 0.78 & 0.91 & 0.91 & 0.57 & 1.26 & 1.26 & 1.38 & 1.34 & 0.63 & 0.87 & 1.47 \\
\hline $\mathrm{Co}$ & 22 & 17 & 12 & 14 & 20 & 6 & 21 & 21 & 20 & 16 & 11 & 17 & 19 \\
\hline $\mathrm{Cr}$ & 67 & 77 & 66 & 85 & 81 & $\begin{array}{l}0 \\
3.1\end{array}$ & 74 & 80 & 80 & 72 & $\begin{array}{l}11 \\
59\end{array}$ & 88 & 87 \\
\hline $\mathrm{Cu}$ & 217 & 793 & 526 & 46 & 43 & 33 & 17 & 48 & 40 & 38 & 28 & 27 & 43 \\
\hline $\mathrm{La}$ & 15 & 16 & 12 & 13 & 15 & 26 & 16 & 16 & 18 & 18 & 16 & 14 & 18 \\
\hline $\mathrm{Nb}$ & 9.1 & 14 & 15 & 13 & 11 & 17 & 16 & 16 & 15 & 13 & 17 & 11 & 12 \\
\hline $\mathrm{Ni}$ & 32 & 32 & 28 & 53 & 51 & 18 & 42 & $\begin{array}{l}10 \\
49\end{array}$ & 51 & 41 & 48 & 35 & 51 \\
\hline $\mathrm{Rb}$ & 17 & 19 & 18 & 68 & 50 & 11 & 14 & 23 & 65 & 80 & 10 & 6 & 63 \\
\hline $\mathrm{Sc}$ & 16 & 11 & 11 & 13 & 33 & 9.8 & 18 & 16 & 16 & 13 & 9.8 & 16 & 22 \\
\hline $\mathrm{Sr}$ & 97 & 25 & 49 & 71 & 281 & 117 & 177 & 200 & 128 & 202 & 49 & 290 & 318 \\
\hline $\mathrm{v}$ & 88 & 116 & 106 & 143 & 116 & 49 & 136 & 124 & 129 & 104 & 92 & 138 & 129 \\
\hline $\mathrm{Y}$ & & & & 19 & 18 & 14 & & & 19 & 18 & 13 & 20 & 20 \\
\hline $\mathrm{Yb}$ & 1.48 & 0.98 & 1.05 & 1.16 & 6.23 & 1.3 & 1.5 & 1.6 & 1.7 & 1.6 & 1.1 & 1.8 & 2.7 \\
\hline $\mathrm{Zn}$ & 137 & 163 & 93 & 109 & 98 & 21 & 76 & 118 & 132 & 89 & 181 & 76 & 95 \\
\hline $\mathrm{Zr}$ & 157 & 146 & 148 & 133 & 142 & 120 & 124 & & 127 & 121 & & & 145 \\
\hline $\mathrm{Se}$ & 7.08 & 11 & & 0.98 & 0.63 & 0.67 & 0.83 & 1.29 & 1.11 & 0.73 & 1.29 & 1.77 & 0.82 \\
\hline $\mathrm{Sb}$ & & & 0.22 & 0.47 & 0.47 & & 0.27 & 0.48 & 0.84 & 0.94 & 0.22 & 0.04 & 0.45 \\
\hline As & 2.68 & 0.39 & 4.54 & 7.63 & 6.18 & 2.06 & 6.52 & 8.38 & 12.4 & 11.7 & 6.31 & 1.51 & 6.60 \\
\hline $\mathrm{n}$ & 8 & 8 & 12 & 21 & 31 & 3 & 9 & 30 & 40 & 102 & 8 & 45 & 50 \\
\hline
\end{tabular}

Note: $\mathrm{Wt} \%=$ weight percent; ppm $=$ parts per million; $\mathrm{Fe}_{2} \mathrm{O}_{3} \mathrm{~T}=$ total iron expressed as $\mathrm{Fe}_{2} \mathrm{O}_{3} ; \mathrm{H}_{2} \mathrm{O}^{\mathrm{T}}=$ total water content of the sample after drying of the sample; $\mathrm{n}=$ number of samples.

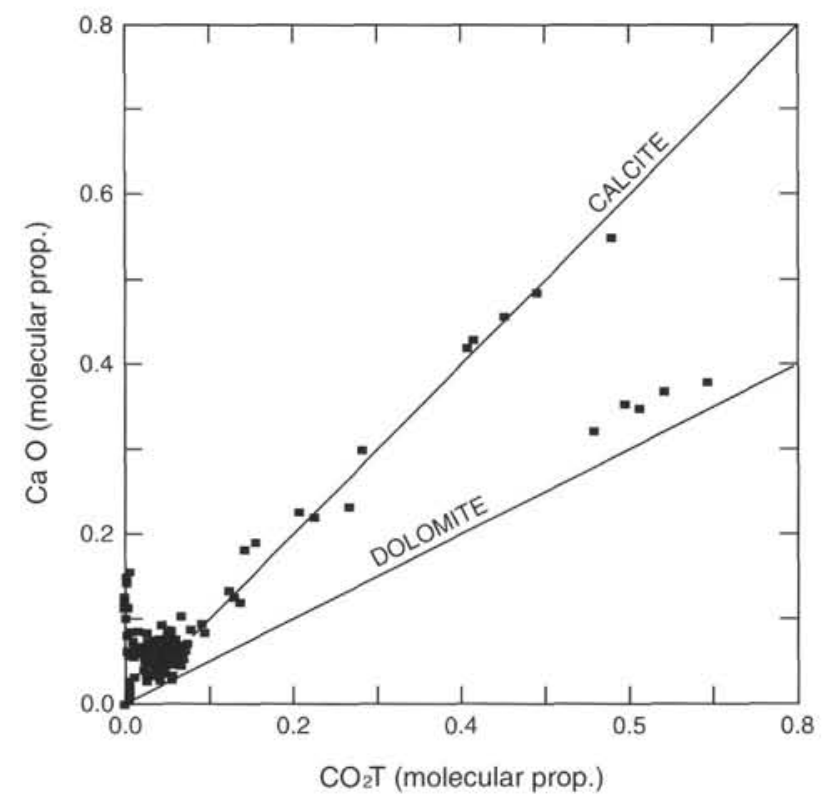

Figure 14. Plot of $\mathrm{CaO}$ (molecular proportions) vs. $\mathrm{CO}_{2} \mathrm{~T}$ (molecular proportions) for sediment samples from Holes $857 \mathrm{~A}$ and $857 \mathrm{C}$. $\log \left(X_{n}^{l}\right)=0$ for immobile components, the intercept value of $\log F_{v}$ is the volume factor for a particular sample. If $F_{v}>1$, there was an increase in volume, whereas $F_{v}<1$ denotes a volume decrease.

The application of Gresens' equations assumes that unaltered and hydrothermally altered samples are from the same protolith. Although volcanic rocks commonly show little chemical variation within a flow, turbiditic and hemipelagic sediments are highly variable in composition because of the effects of sedimentation on grain size and mineralogy. Thus, the compositions of sediment protolith are highly variable. Turbiditic silt and sand contain greater $\mathrm{SiO}_{2}, \mathrm{Na}_{2} \mathrm{O}$, and $\mathrm{Zr}$, and lower $\mathrm{Al}_{2} \mathrm{O}_{3}, \mathrm{MgO}$, and $\mathrm{K}_{2} \mathrm{O}$ contents compared to hemipelagic silty clay (Table 2 ). It is essential, therefore, that hydrothermally altered sediment be carefully matched to unaltered sediment in Middle Valley before calculating absolute chemical changes.

For hydrothermally altered sediments from Middle Valley, samples were first classified on the basis of texture and grain size using petrographic methods. The chemical mobility of elements was then evaluated using Gresens' technique (Gresens, 1967). Of all the elements determined, $\mathrm{TiO}_{2}$ and $\mathrm{Yb}$ displayed similar $F_{v}$ values (Table 4) indicating that they behaved similarly during alteration and were, therefore, least mobile. Zirconium also behaved similarly but was not used in the mass balance calculations because it is generally more erratic due to its occurrence as a heavy mineral during sedimentation. $\mathrm{Al}_{2} \mathrm{O}_{3}$ behaved coherently with $\mathrm{TiO}_{2}$ and $\mathrm{Yb}$ in weakly to moderately altered sediment but was clearly mobilized, at least locally, in intensely altered sediment in the core of both the AAV and BH upflow zones. Because $\mathrm{TiO}_{2}, \mathrm{Yb}$, and $\mathrm{Zr}$ are relatively immobile during hydro- 

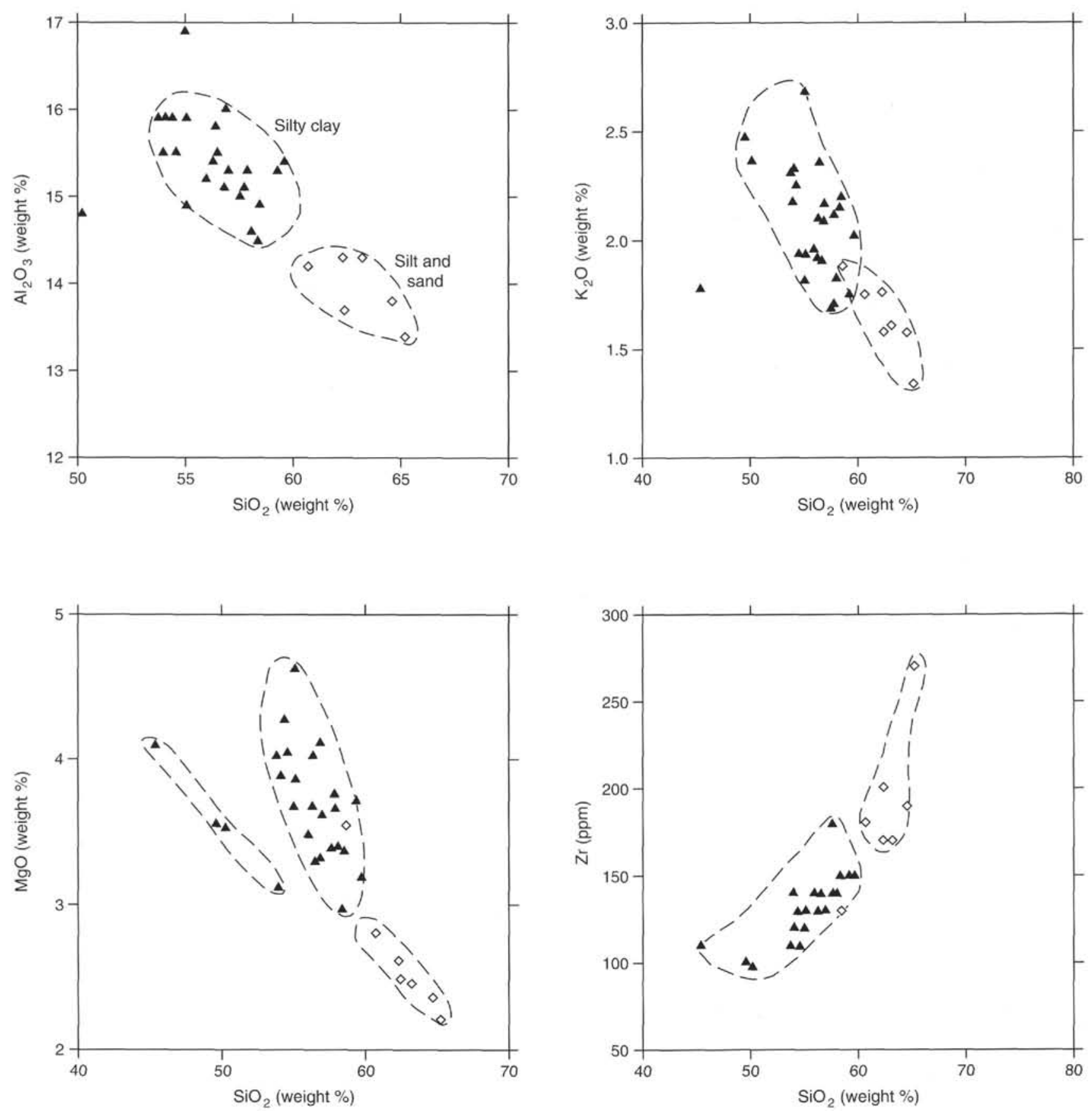

Figure 15. Binary scatter plots of $\mathrm{Al}_{2} \mathrm{O}_{3}, \mathrm{~K}_{2} \mathrm{O}, \mathrm{MgO}$, and $\mathrm{Zr}$ vs. $\mathrm{SiO}_{2}$ illustrating the control of grain size on the chemical composition of bulk sediment, $\mathrm{Hole} 857 \mathrm{~A}$.

thermal alteration at Middle Valley, and have been shown to be immobile in other studies (e.g., Winchester and Floyd, 1976; Floyd and Winchester, 1978; Maclean and Kranidiotis, 1987), and their abundances vary systematically with grain-size, they were used to match the sedimentary protoliths of altered and unaltered samples. $\mathrm{TiO}_{2}$ and $\mathrm{Yb}$ are concentrated along with $\mathrm{Al}_{2} \mathrm{O}_{3}$ in hemipelagic silty clay, whereas $\mathrm{Zr}$, present as zircon, occurs with detrital quartz in turbiditic silt and sand (Fig. 15).

The absolute weight changes between parent sediment and a representative sample of each alteration zone $\left(W_{A}-W_{B}\right)$ (Table 4$)$ were calculated using the computer program GRES (Leitch and Day, 1990). Table 5 summarizes groups of elements that show major gains or losses in each alteration zone. Zone Ia-1, the inner core of the BH upflow zone, shows major gains of $\mathrm{SiO}_{2}(32 \mathrm{wt} \%), \mathrm{Al}_{2} \mathrm{O}_{3}$ (8.6wt $\%$ ), $\mathrm{Fe}_{2} \mathrm{O}_{3} \mathrm{~T}$ (13.8 wt $\%), \mathrm{MgO}(3.0 \mathrm{wt} \%)$, and $\mathrm{S}(2.0 \mathrm{wt} \%)$ and depletions of $\mathrm{CaO}$ (3.5 wt \%), $\mathrm{K}_{2} \mathrm{O}(0.9 \mathrm{wt} \%)$ and $\mathrm{Na}_{2} \mathrm{O}(2.9 \mathrm{wt} \%)$. Zone Ia2, which surrounds Zone Ia-1, shows gains of $\mathrm{MgO}(7.4 \mathrm{wt} \%)$ and losses of $\mathrm{K}_{2} \mathrm{O}(1.7 \mathrm{wt} \%)$ and $\mathrm{CaO}(3.7 \mathrm{wt} \%), \mathrm{CO}_{2}$ and $\mathrm{TOC}$ have been depleted in both zones. Zone IIa shows major increases of $\mathrm{SiO}_{2}, \mathrm{MgO}, \mathrm{Na}_{2} \mathrm{O}$ and $\mathrm{S}$, and decreases of $\mathrm{CaO}, \mathrm{K}_{2} \mathrm{O}, \mathrm{CO}_{2}$, and TOC. In Zone IIIa, $\mathrm{MgO}$, $\mathrm{K}_{2} \mathrm{O}, \mathrm{Fe}_{2} \mathrm{O}_{3} \mathrm{~T}$, and $\mathrm{S}$ increase, and $\mathrm{CaO}$ and $\mathrm{CO}_{2}$ decrease, whereas Zone IVa is enriched in $\mathrm{CaO}$ and $\mathrm{CO}_{2}$.

At AAV (Site 858), the inner core of the upflow zone (Zone Ib) shows major additions of $\mathrm{SiO}_{2}(51 \mathrm{wt} \%), \mathrm{Al}_{2} \mathrm{O}_{3}(3.7 \mathrm{wt} \%)$, and $\mathrm{CaO}$ (6.4 wt \%), and depletions of $\mathrm{Fe}_{2} \mathrm{O}_{3} \mathrm{~T}$ (3.9 wt \%), $\mathrm{MgO}$ (2.2 wt \%), $\mathrm{Na}_{2} \mathrm{O}(2.4 \mathrm{wt} \%), \mathrm{K}_{2} \mathrm{O}(1.7 \mathrm{wt} \%)$, and $\mathrm{CO}_{2} \mathrm{~T}(1.2 \mathrm{wt} \%)$. Zones IIb and 


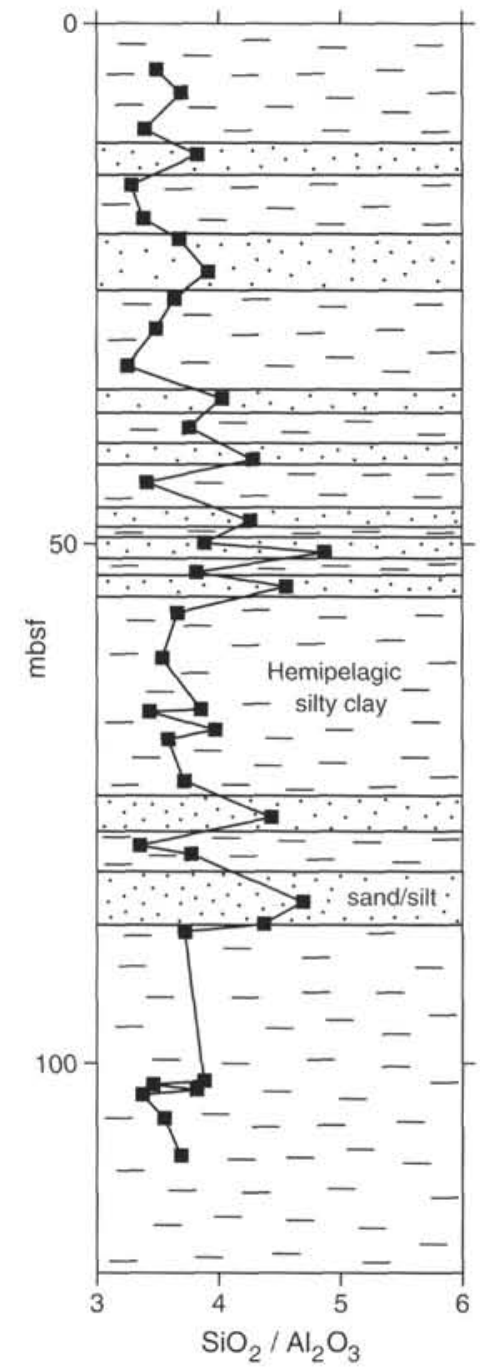

Figure 16. Downhole profile of $\mathrm{SiO}_{2} / \mathrm{Al}_{2} \mathrm{O}_{3}$ ratios for Hole 857A outlining turbiditic intervals characterized by high ratios that decrease upward as the proportion of clay minerals increase at the expense of quartz.

IIIb have generally gained $\mathrm{MgO}, \mathrm{Na}_{2} \mathrm{O}$, and $\mathrm{Al}_{2} \mathrm{O}_{3}$ at the expense of $\mathrm{CaO}, \mathrm{CO}_{2} \mathrm{~T}$, and $\mathrm{K}_{2} \mathrm{O}$, whereas Zones IVb has gained both $\mathrm{MgO}$ and $\mathrm{FeO}$ and lost $\mathrm{CaO}$ and $\mathrm{CO}_{2}$. Zones $\mathrm{Vb}$ and $\mathrm{VIb}$ show major additions of $\mathrm{CaO}$ and $\mathrm{MgO}$, respectively.

At Site 857 , Zone Ic of the hydrothermal reaction zone in the sill complex displays gains and losses that are similar to those calculated for Zone Ib in the core of the AAV upflow zone (Table 4). Zone Ic is characterized by major gains of $\mathrm{SiO}_{2}, \mathrm{CaO}$, and $\mathrm{Al}_{2} \mathrm{O}_{3}$, and losses of $\mathrm{Na}_{2} \mathrm{O}, \mathrm{K}_{2} \mathrm{O}$, and $\mathrm{CO}_{2} \mathrm{~T}$. Zone IIIc, which is characterized by the albitechlorite-pyrite assemblage in Hole $857 \mathrm{C}$, shows a major increase in $\mathrm{Na}_{2} \mathrm{O}(1.4 \mathrm{wt} \%)$.

The absolute mass changes for most of the remaining elements are $<1.0 \mathrm{wt} \%$, although many of these elements display large gains or losses relative to their contents in unaltered parent sediment. Relative element gains or losses, expressed as $\log W_{B} / W_{A}$, (Eq. 2) were calculated using computer program NEWGRES (Leitch and Day, 1990). In Zones Ia-1, IIa, IVa, Vb, and VIb, for example, $\mathrm{MnO}$ displays mass gains over unaltered sediment of $350 \%$ to $1700 \%$ (Table 6). Similarly, $\mathrm{Cu}$ displays mass gains of $1300 \%$ to $7600 \%$ in Zones Ia-1 and Ia-2, but shows losses of $41 \%$ to $46 \%$ in Zones Ib and Ic. Other elements that display significant mass losses of about $50 \%$ or greater in the reaction zone (Zone Ic, Site 857) and the AAV upflow zone (Zone Ib, Site 858 ) include $\mathrm{Ba}, \mathrm{Co}, \mathrm{Ni}, \mathrm{Rb}, \mathrm{Zn}, \mathrm{Se}$, and $\mathrm{As}$.

\section{DISCUSSION}

\section{Hydrothermal Upflow Zones}

Hydrothermally altered sediments at $\mathrm{BH}$ are distributed about an inactive massive sulfide mound that is $35 \mathrm{~m}$ high and at least $96 \mathrm{~m}$ thick (Goodfellow and Franklin, 1993; Davis, Mottl, Fisher, et al., 1992). Pyrrhotite-chalcopyrite veins that cut brecciated lithified sediment near the bottom of Hole $856 \mathrm{~B}$ adjacent to the $\mathrm{BH}$ sulfide deposit probably represent the core of the hydrothermal-fluid upflow. Away from this intensely altered core, the sediments are progressively less altered. At AAV hemipelagic and turbiditic sediments are similarly zoned from an intensely altered core outward to less altered sediment. The alteration zones have a convex-upward morphology in two dimensions (Fig. 5) that is similar to alteration patterns determined by Goodfellow et al. (1993) and mimics the shape of isopleths of $\mathrm{Si}, \mathrm{Mg}$, $\mathrm{Ba}$, and $\mathrm{Ca}$ in pore waters in shallow $(<10 \mathrm{~m})$ cores from this site (Lydon et al., 1991).

Because sediments nearest centers of fluid discharge at Middle Valley have been hydrothermally lithified, they are commonly fractured and brecciated, producing the high permeability in the core of the upflow zone (Davis, Mottl, Fisher, et al., 1992; C. Rohr, pers. comm., 1993). Near the center of fluid discharge, the permeability is, therefore, mostly controlled by fractures that are lined with hydrothermal minerals. Multiple vein-sets, rebrecciated breccias, and crackseal textures (Ramsay, 1980) indicate that several episodes of sealing by the precipitation of hydrothermal minerals in open spaces, fluid overpressuring, and subsequent rupturing have occurred. Since the sealing and breaching of the upflow zone most likely occur episodically, there are temporal variations in the lateral migration of hydrothermal-fluids and the entrainment of seawater. Changes in the physical properties of the sediment during hydrothermal alteration would also affect the style and extent of hydrothermal alteration. Highly indurated hemipelagic sediments would deform brittlely in response to hydrofracturing, which would increase the permeability in the hightemperature core of fluid discharge conduits. The precipitation of calcite and pyrite in the grain interstices of turbiditic silt and sand, and the absence of veins cutting hemipelagic sediment indicate that fluids migrated laterally along permeable layers because of the low crossstratal permeability near the weakly altered margins of the fluid upflow zone (Goodfellow et al., 1993). During periods when fractures are open and fluid discharge is less restricted, however, seawater would probably be entrained into the discharge conduit, resulting in the precipitation of most $\mathrm{Mg}$ as $\mathrm{Mg}$-rich silicates. The zone of high fracture-controlled permeability may have propagated upward and expanded outward from the center of fluid upflow over time. Such an expanding hydrothermal front may have produced the mineralogical and chemical zonation documented at BH and the AAV (Leybourne and Goodfellow, this volume). Components that were dissolved from altered sediment near the center of fluid discharge (e.g., $\mathrm{Ca}, \mathrm{CO}_{2}, \mathrm{~K}$, $\mathrm{Na}, \mathrm{Sr}$, and $\mathrm{Rb}$ ) migrated upward and outward and were precipitated with hydrothermal components largely originating from end-member hydrothermal fluids (e.g., $\mathrm{H}_{2} \mathrm{~S}, \mathrm{Ba}, \mathrm{Zn}, \mathrm{As}, \mathrm{Se}, \mathrm{Sb}$ ) near the transition between fractured and highly permeable indurated sediment, and less permeable soft, hemipelagic silty clay.

\section{Bent Hill (Site 856)}

Holes $856 \mathrm{~A}$ and $856 \mathrm{~B}$ intersected alteration zones north of the $\mathrm{BH}$ massive sulfide deposit (Fig. 3). The morphology of the upflow zone and its spatial relationship to the sulfide deposit presently cannot be determined because of the paucity of drill holes. The cross-sectional nature of the upflow zone, however, can be determined from Holes $856 \mathrm{~A}$ and $856 \mathrm{~B}$ (Fig. 7). Hemipelagic and turbiditic sediments between 110 and 120 mbsf in Hole $856 \mathrm{~B}$ are brecciated and crosscut by quartz-sulfide veins (Zone Ia). Open spaces in the hydrothermal breccias are infilled by hydrothermal silicates, mostly quartz, muscovite, and chlorite (Leybourne and Goodfellow, this volume). This 
Table 4. Losses and gains $\left(W_{B}-W_{A}\right)$ of elements in hydrothermal alteration zones associated with the $B H$ and AAV fluid upflow conduits, and the reaction zones below 450 mbsf at Site 857.

\begin{tabular}{|c|c|c|c|c|c|c|c|c|c|c|c|c|c|c|c|c|c|c|c|c|c|c|c|}
\hline \multirow[b]{2}{*}{ Location } & \multirow[b]{2}{*}{ Sample number } & \multirow[b]{2}{*}{ Zone } & \multirow[b]{2}{*}{$\mathrm{Fv}\left(\mathrm{TiO}_{2}\right)$} & \multirow[b]{2}{*}{$\mathrm{Fv}(\mathrm{Yb})$} & \multirow[b]{2}{*}{$\begin{array}{l}\text { Density } \\
(\mathrm{g} / \mathrm{cc})\end{array}$} & \multicolumn{18}{|c|}{ Gains and losses in weight percent } \\
\hline & & & & & & $\mathrm{SiO}_{2}$ & $\mathrm{TiO}_{2}$ & $\mathrm{Al}_{2} \mathrm{O}_{3}$ & $\mathrm{Fe}_{2} \mathrm{O}_{3} \mathrm{~T}$ & $\mathrm{Fe}_{2} \mathrm{O}_{3}$ & $\mathrm{FeO}$ & $\mathrm{MnO}$ & $\mathrm{MgO}$ & $\mathrm{CaO}$ & $\mathrm{Na}_{2} \mathrm{Oc}$ & $\mathrm{K}_{2} \mathrm{O}$ & $\mathrm{P}_{2} \mathrm{O}_{5}$ & $\mathrm{H}_{2} \mathrm{OT}$ & $\mathrm{s}$ & $\mathrm{CO}_{2} \mathrm{~T}$ & $\mathrm{CO}_{2}$ & TOC & \\
\hline & $856 \mathrm{~A}-8 \mathrm{H}-1,8-10 \mathrm{~cm}$ & IVa & 1.21 & 0.94 & 2.78 & -4 & -0.1 & -1.7 & -0.9 & -1.5 & 0.5 & 0.23 & 2.2 & 6.8 & -0.3 & -0.7 & 0.15 & 0.5 & 0.3 & 5.3 & 5.4 & -0.08 & \\
\hline \multirow{4}{*}{ (Bent Hill) } & $856 \mathrm{~B}-6 \mathrm{H}-6,118-122 \mathrm{~cm}$ & IIIla & 1.00 & 1.16 & 2.77 & 3 & 0.1 & 2.3 & 1.8 & -1.3 & 6.5 & 0.09 & 3.6 & -3.4 & -1.5 & 1.2 & 0.02 & 2.4 & 0.8 & -0.4 & -0.7 & 0.03 & \\
\hline & $856 \mathrm{~B}-13 \mathrm{X}-4,128-132 \mathrm{~cm}$ & Ila & 1.03 & 1.17 & 2.92 & 12 & 0.1 & 2.5 & 0.0 & ND & ND & 0.61 & 4.4 & -3.3 & 1.1 & -0.9 & 0.02 & 1.9 & 0.8 & -1.1 & -0.7 & -0.18 & \\
\hline & $856 \mathrm{~B}-15 \mathrm{X}-6,6-8 \mathrm{~cm}$ & la-2 & 1.08 & 1.03 & 2.80 & 2 & 0.0 & -0.7 & 0.1 & -0.7 & 0.8 & -0.05 & 7.4 & -3.7 & -2.8 & -1.7 & 0.05 & 4.7 & 0.8 & -1.3 & -0.7 & -0.19 & \\
\hline & $856 \mathrm{~B}-15 \mathrm{X}-1,91-93 \mathrm{~cm}$ & Ia-1 & 1.24 & 1.75 & 2.84 & 32 & 0.2 & 8.6 & 13.8 & ND & ND & 0.28 & 3.0 & -3.5 & -2.9 & 0.9 & -0.03 & -3.2 & 2.0 & -0.7 & -0.7 & -0.14 & \\
\hline \multirow{6}{*}{$\begin{array}{l}\text { Site } 858 \\
\text { (AAV) }\end{array}$} & $858 \mathrm{~B}-5 \mathrm{H}-1,140-143 \mathrm{~cm}$ & VIb & 1.50 & 2.27 & 2.67 & 17 & 0.2 & 1.9 & 0.5 & -0.3 & 0.8 & 0.28 & 48.3 & -0.2 & -0.6 & -1.6 & -0.07 & 15.8 & -0.1 & 0.1 & ND & ND & \\
\hline & $858 \mathrm{C}-3 \mathrm{H}-1,78-81 \mathrm{~cm}$ & $\mathrm{Vb}$ & 4.77 & 4.04 & 2.70 & 6 & -0.1 & 1.7 & 2.9 & ND & ND & 1.44 & 0.3 & 174.0 & -1.1 & 0.7 & 0.93 & -3.2 & 7.1 & 141.0 & 141.0 & 0.14 & \\
\hline & $858 \mathrm{~A}-18 \mathrm{X}-3,14-16 \mathrm{~cm}$ & IVb & 0.98 & 0.87 & 2.86 & -7 & -0.1 & 0.8 & 1.4 & -1.4 & 2.6 & 0.05 & 3.9 & -2.6 & -0.6 & -0.3 & 0.00 & 2.3 & 0.2 & -0.8 & -0.7 & -0.11 & \\
\hline & $858 \mathrm{~A}-30 \mathrm{X}-1,67-70 \mathrm{~cm}$ & IIIb & & 1.15 & 2.79 & 0 & 0.1 & 2.5 & 0.9 & -1.8 & 2.7 & 0.06 & 3.1 & -2.3 & 1.2 & -0.5 & 0.04 & 1.6 & 0.2 & -0.8 & -0.7 & -0.90 & \\
\hline & $858 \mathrm{~F}-25 \mathrm{R}-1,19-21 \mathrm{~cm}$ & IIb & 95 & 1.26 & 2.70 & 2 & 0.1 & 3.2 & 1.1 & -1.6 & 2.4 & 0.07 & 4.5 & -2.0 & 1.6 & -0.9 & 0.01 & 2.0 & -0.1 & -0.8 & -0.7 & -0.08 & \\
\hline & $858 \mathrm{~F}-9 \mathrm{R}-1,18-20 \mathrm{~cm}$ & $\mathrm{Ib}$ & 1.75 & 1.35 & 2.70 & 51 & -0.1 & 3.7 & -3.9 & -1.7 & -1.9 & -0.04 & -2.2 & 6.4 & -2.4 & -1.7 & 0.00 & 3.2 & -0.1 & -1.2 & -0.7 & -0.15 & \\
\hline \multirow[t]{3}{*}{ Site 857} & $857 \mathrm{C}-2 \mathrm{IR}-3,27-29 \mathrm{~cm}$ & IIIc & 1.12 & 1.17 & 2.60 & 6 & 0.0 & 2.1 & 0.9 & -0.5 & 1.2 & 0.01 & 0.1 & -1.2 & 1.4 & 0.1 & 0.04 & 0.2 & 0.0 & -0.3 & -0.6 & 0.03 & \\
\hline & $857 \mathrm{D}-17 \mathrm{R}-3,23-25 \mathrm{~cm}$ & Ic & 1.96 & 1.61 & 2.82 & 72 & -0.1 & 5.4 & 1.2 & 3.4 & -1.8 & 0.19 & -0.4 & 11.8 & -2.7 & -1.7 & 0.00 & 0.1 & 0.0 & -1.5 & ND & ND & \\
\hline & & & & & \multicolumn{19}{|c|}{ Gains and losses in parts per million } \\
\hline Location & Sample number & Zone & $\mathrm{Fv}\left(\mathrm{TiO}_{2}\right)$ & $\mathrm{Fv}(\mathrm{Yb})$ & $\mathrm{Ba}$ & $\mathrm{Be}$ & Co & $\mathrm{Cr}$ & $\mathrm{Cu}$ & $\mathrm{La}$ & $\mathrm{Nb}$ & $\mathrm{Ni}$ & $\mathrm{Rb}$ & $\mathrm{Sc}$ & $\mathrm{Sr}$ & V & $\mathrm{Y}$ & $\mathrm{Yb}$ & $\mathrm{Zn}$ & $\mathrm{Zr}$ & $\mathrm{Se}$ & $\mathrm{Sb}$ & As \\
\hline Site 856 & $856 \mathrm{~A}-8 \mathrm{H}-1,8-10 \mathrm{~cm}$ & IVa & 1.21 & 0.94 & -129 & -0.1 & 0 & -19 & -14 & 2 & -7 & -10 & -19 & -4 & 40 & -25 & 5 & 0.3 & 15 & -8 & -0.6 & 0.00 & -1.6 \\
\hline \multirow{3}{*}{ (Bent Hill) } & $856 \mathrm{~B}-6 \mathrm{H}-6,118-122 \mathrm{~cm}$ & IIIa & & & 90 & 0.2 & 6 & 4 & & 1 & 7 & 10 & 39 & 3 & -252 & 23 & 1 & -0.1 & 62 & -8 & -0.5 & 0.18 & 4.7 \\
\hline & $856 \mathrm{~B}-13 \mathrm{X}-4,128-132 \mathrm{~cm}$ & IIa & 1.03 & 1.17 & -313 & 0.1 & 4 & -6 & -16 & 0 & 10 & -7 & -25 & 1 & -258 & 11 & 0 & -0.1 & 1 & 3 & -0.7 & -0.12 & -0.1 \\
\hline & & la-2 & 1.08 & 1.03 & -436 & -0.6 & -16 & -91 & 488 & -12 & 5 & -52 & -46 & -2 & -223 & -110 & -3 & 0.1 & -77 & -9.83 & 0.5 & -0.13 & -5.7 \\
\hline & $\mathrm{X}-1,91-93 \mathrm{~cm}$ & la-1 & 1.24 & 1.75 & 193 & 0.2 & 14 & 16 & 3066 & -4 & 3 & -4 & 3 & -11 & 5 & 21 & 5 & -0.3 & 137 & 21 & 3.8 & -0 . & -4.5 \\
\hline \multirow{6}{*}{$\begin{array}{l}\text { Site } 858 \\
\text { (AAV) }\end{array}$} & $858 \mathrm{~B}-5 \mathrm{H}-1,140-143 \mathrm{~cm}$ & VIb & 1.50 & 2.27 & -361 & -0.3 & -4 & 19 & -22 & 1 & 25 & 16 & -33 & 0 & -196 & 91 & -2 & -0.3 & -25 & 71 & -0.8 & -0 . & 2.0 \\
\hline & $858 \mathrm{C}-3 \mathrm{H}-1,78-81 \mathrm{~cm}$ & $\mathrm{Vb}$ & 4. & 4.6 & 643 & 4.0 & 4 & 3 & 25 & 27 & 32 & -14 & 22 & 0 & 20 & 57 & 24 & 0.2 & -2 & -23 & 5.3 & 4.30 & 57.0 \\
\hline & $\mathrm{L}-3,14-16 \mathrm{~cm}$ & IVb & & 0.8 & -2 & 0.1 & -1 & -25 & 2 & -4 & 4 & 2 & -8 & 1 & -2 & 25 & 3 & 0.1 & 17 & -44 & 0.3 & -0.14 & -4.1 \\
\hline & $-30 X-1,67-70 \mathrm{~cm}$ & IIIIb & & 1. & -279 & 0.1 & 5 & -17 & -12 & 0 & 7 & -9 & -12 & 3 & -194 & 28 & -2 & -0.2 & 21 & -45 & 0.1 & 0.21 & 7.8 \\
\hline & $858 \mathrm{~F}-25 \mathrm{R}-1,19-21 \mathrm{~cm}$ & $\mathrm{IIb}$ & 0.95 & 1.26 & -226 & 0.2 & -4 & -3 & 5 & -2 & 6 & -12 & -29 & 5 & -123 & 46 & 0 & -0.2 & 23 & -18 & 1.1 & -0.13 & -3.2 \\
\hline & $858 \mathrm{~F}-9 \mathrm{R}-1,18-20 \mathrm{~cm}$ & $\mathrm{Ib}$ & 1.75 & 1.35 & -413 & -0.4 & -11 & -13 & -23 & 8 & 19 & -30 & -37 & -4 & -219 & -38 & 0 & 0.3 & -51 & 80 & -0.8 & -0.09 & -5.9 \\
\hline \multirow[t]{2}{*}{ Site 857} & $857 \mathrm{C}-21 \mathrm{R}-3,27-29 \mathrm{~cm}$ & IIIc & 1.12 & 1.17 & 53 & 0.2 & 2 & -6 & -2 & 1 & 2 & -11 & -1 & 1 & -26 & 0 & 2 & 0.0 & 11 & -9 & 1.6 & 0.01 & -0.8 \\
\hline & $857 \mathrm{D}-17 \mathrm{R}-3,23-25 \mathrm{~cm}$ & $\mathrm{Ic}$ & 1.96 & 1.61 & -398 & -0.3 & -10 & -31 & -22 & $i$ & 10 & -32 & -34 & -2 & 252 & -27 & 2 & 0.2 & -43 & 53 & -0.5 & -0.06 & -5.6 \\
\hline
\end{tabular}

Notes: Volume factors calculated using $\mathrm{TiO}_{2}$ and $\mathrm{Yb}$ as immobile elements. $\mathrm{ND}=$ not determined; $\mathrm{Fv}=$ volume factor. 

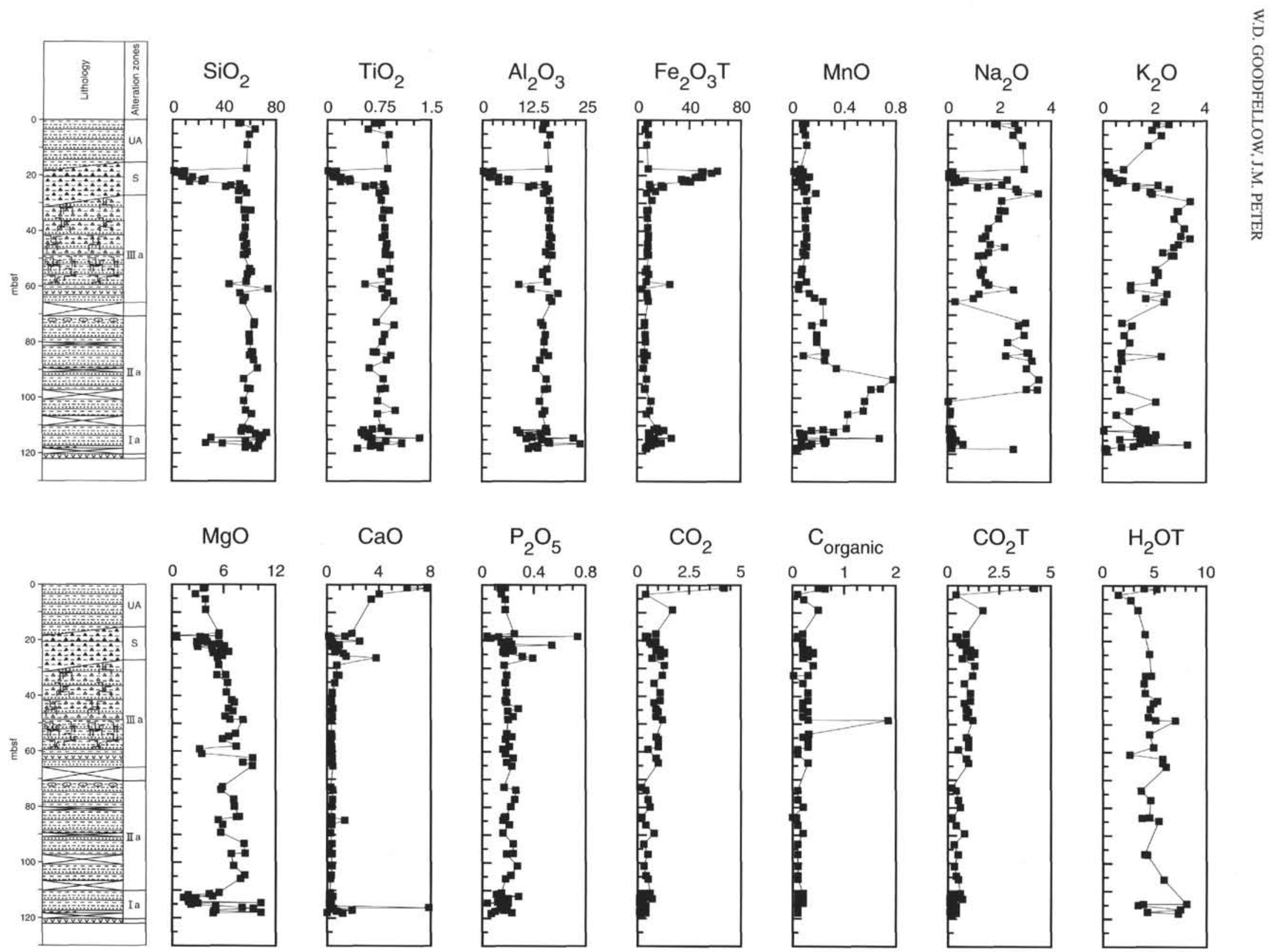

Figure 17A. Downhole profiles of major element bulk compositions for altered and unaltered hemipelagic and turbiditic sediments, Hole 856B. 

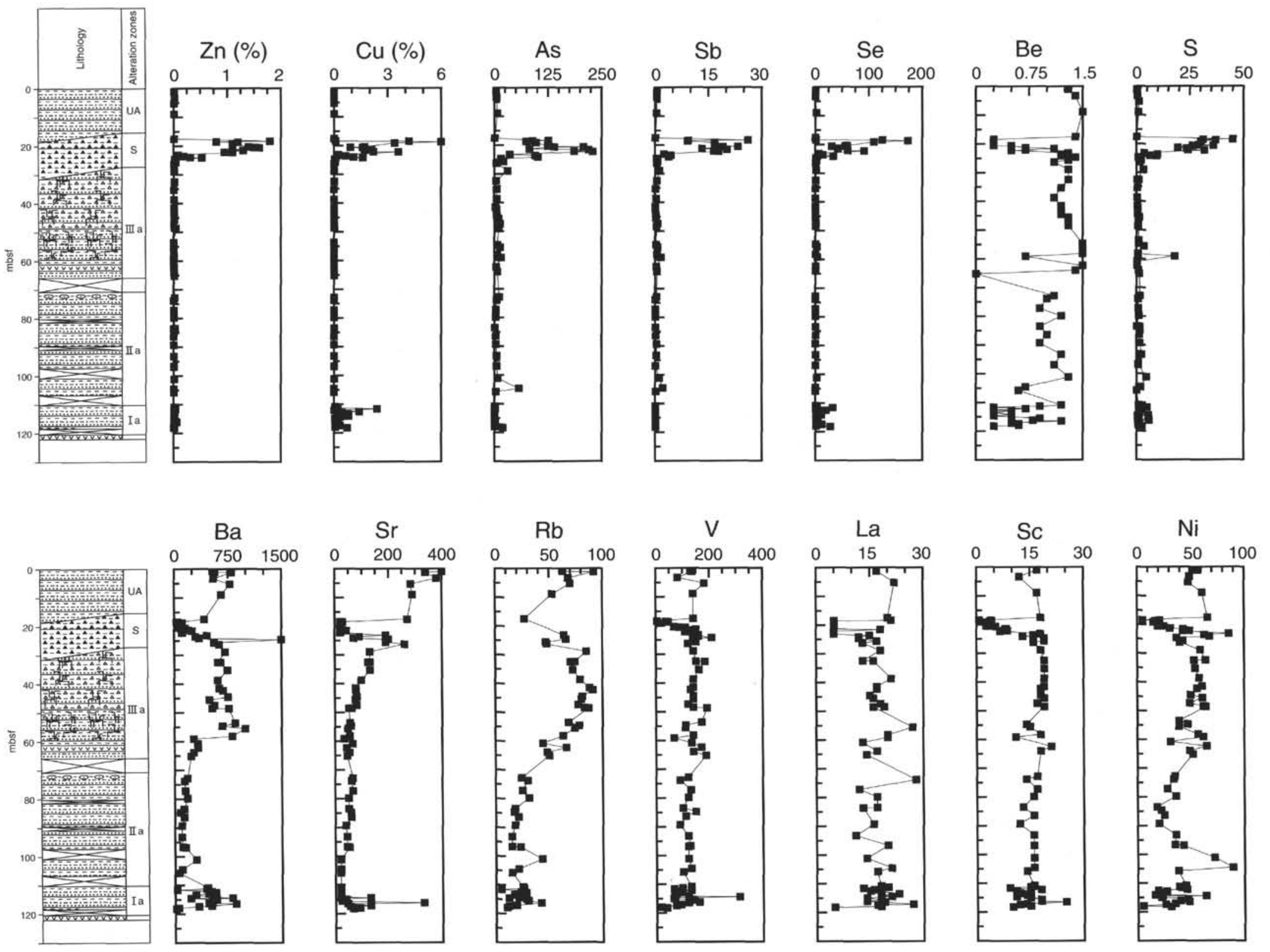

Figure 17B. Downhole profiles of minor and trace element bulk compositions for altered and unaltered hemipelagic and turbiditic sediments, Hole $856 \mathrm{~B}$. 

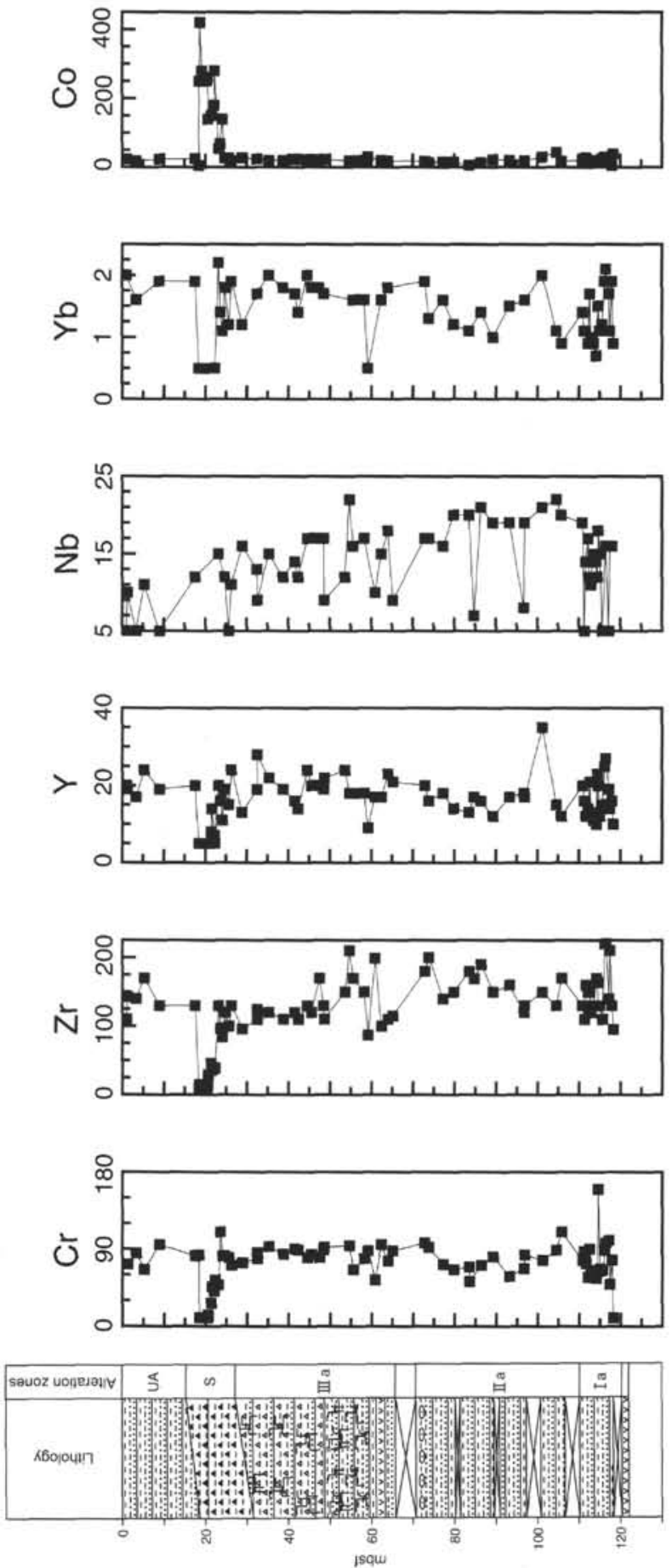

breccia- and fracture-controlled permeability extends into the overlying alteration zone (Zone IIa) where hemipelagic and turbiditic sediment are also indurated, but are less commonly fractured and veined. In Zone IIIa, which overlies Zone IIa in Hole 856B, hemipelagic sediment is moderately indurated, brecciated, and locally crosscut by veins. The bleaching and silicification of the breccia matrix and the preferential occurrence of pyrite in the matrix over clasts indicates that fluid flow was focussed within the more permeable matrix. This alteration is distinct from the outermost alteration zone (Zone IVa in Hole $856 \mathrm{~A}$ ), which is characterized by weakly to nonindurated sediments that are variably cemented by calcite and which also contain carbonate concretions.

The core of the $\mathrm{BH}$ upflow zone is characterized by a high-temperature (up to $338^{\circ} \mathrm{C}$; Peter et al., this volume) mineral assemblage consisting of quartz + chlorite + muscovite + rutile + pyrrhotite + chalcopyrite (Zone Ia-1). These minerals replace detrital and diagenetic minerals in hemipelagic and turbiditic sediments, form veins which cut altered sediment, and infill open spaces within hydrothermal breccias. In Zone Ia-1, detrital K-feldspar and plagioclase are replaced by Fe-rich chlorite and muscovite. This replacement has resulted in the depletion of most alkali elements $(\mathrm{Na}, \mathrm{Rb}, \mathrm{Sr}$, and $\mathrm{Ba})$ and the addition of $\mathrm{Fe}$ and $\mathrm{Mg}$. The occurrence of sulfide veinlets (mostly pyrrhotite and chalcopyrite) is reflected by marked increases of S, Cu, Se, and Mo. Detrital epidote has been destroyed in this zone. The extent of $\mathrm{K}$ addition and $\mathrm{Ca}$ depletion in Zone Ia-1 is illustrated by plotting samples from this zone on a ternary $\left(\mathrm{MgO}+\mathrm{Na}_{2} \mathrm{O}\right)-\mathrm{K}_{2} \mathrm{O}$ - $\mathrm{CaO}$ diagram (Fig. 24). Samples from Zone Ia-1 plot along the $\left(\mathrm{MgO}+\mathrm{Na}_{2} \mathrm{O}\right) / 2-\mathrm{K}_{2} \mathrm{O}$ join, away from the field of unaltered sediment and toward $\mathrm{K}_{2} \mathrm{O}$.

Fluid inclusion temperatures measured in quartz range between $181^{\circ}$ and $338^{\circ} \mathrm{C}$ (Peter et al., this volume). These are consistent with temperatures estimated from chlorite compositions (Leybourne and Goodfellow, this volume) and estimated minimum temperatures of $300^{\circ} \mathrm{C}$ based on $\mathrm{Cu}$ and $\mathrm{Fe}$ sulfide solubility considerations (Crerar and Barnes, 1976). The rate of precipitation of metals during cooling of a $400^{\circ} \mathrm{C}$ fluid that had equilibrated with basalt with a fluid/basalt ratio of unity was determined by Seewald and Seyfried (1990). Mn and $\mathrm{Zn}$ do not show major changes but $\mathrm{Cu}$ and $\mathrm{Fe}$ drop off quickly and are therefore more useful in estimating original compositions and temperatures for fluids that have cooled during ascent to the seafloor.

The Fe content of chlorite in Zone Ia indicates that hydrothermal chlorite formed from a $\mathrm{Mg}$-depleted, end-member hydrothermal fluid that was probably similar to high-temperature $\left(>350^{\circ} \mathrm{C}\right)$, basaltequilibrated hydrothermal fluids that vent along nonsedimented oceanic rifts (Edmond et al., 1979; Von Damm, 1990). The primary pyrrhotite-isocubanite-wurtzite assemblage at $\mathrm{BH}$ is interpreted to have precipitated from such fluids (Goodfellow and Franklin, 1993). This sulfide assemblage is a common product of high-temperature $\left(>350^{\circ} \mathrm{C}\right)$ "black smoker" fluids venting along oceanic rifts (e.g., Francheteau et al., 1979; Goldfarb et al., 1983; Haymon, 1983; Oudin, 1983). Furthermore, the high fracture-controlled permeability, hydrothermal fluid-dominated mineral assemblages and high fluid temperatures (Peter et al., this volume) indicate that the core of the upflow zone was characterized by high hydrothermal water/rock ratios and hydrostatic pressures that exceeded lithostatic pressures.

Zone IIa, which surrounds the inner core (Zone Ia), is characterized by the albitization of plagioclase and the chloritization of orthoclase, illite, and mica. These alteration reactions have caused a depletion in $\mathrm{K}, \mathrm{Rb}, \mathrm{Ba}$, and $\mathrm{Sr}$ and an increase in $\mathrm{Mg}$ and $\mathrm{Na}$ (Fig. 23). The $\mathrm{Mg}$-metasomatism of sedimentary silicates indicates that unmodified (Mg-rich) seawater was entrained into the upflow zone. Mass balance calculations show that up to $0.13 \mathrm{~g} / \mathrm{cm}^{3}$ of $\mathrm{Mg}$ have been added to Zone IIa. Using a seawater $\mathrm{Mg}$ content of $52.8 \mathrm{mmol} / \mathrm{kg}$ for Middle Valley seawater (Butterfield et al., this volume) and assuming that all $\mathrm{Mg}$ was precipitated, a minimum water/rock mass ratio of 35.6 is calculated. $\mathrm{Mg}$ metasomatism is entirely prograde and occurs predominantly at the margins of the hydrothermal upflow zone. This process 
Table 5. Summary of element gains and losses in hydrothermal alteration zones associated with the BH and AAV fluid upflow conduits, and the reaction zones below 450 mbsf at Site 857.

\begin{tabular}{|c|c|c|c|}
\hline Alteration zone & Mineral assemblage & Elements added & Elements removed \\
\hline \multicolumn{4}{|c|}{ Bent Hill (Site 856) } \\
\hline Ia-1 & Qz-Ch-Ms-Ru-Cp-Po & $\begin{array}{c}\mathrm{Si}, \mathrm{Fe}^{\mathrm{T}}, \mathrm{Al}, \mathrm{Mg}, \mathrm{S}, \mathrm{K}, \mathrm{Mn} \\
\mathrm{Cu}, \mathrm{Ba}, \mathrm{Zn}, \mathrm{Se}, \mathrm{Co}, \mathrm{Cr}\end{array}$ & $\begin{array}{l}\mathrm{Ca}, \mathrm{Na}, \mathrm{CO}_{2}, \mathrm{TO}, \mathrm{As}, \\
\mathrm{Sc}\end{array}$ \\
\hline Ia-2 & Ch-Sm-Fp-Qz & $\mathrm{Mg}, \mathrm{Fe}^{2+}, \mathrm{Rb}, \mathrm{Cu}, \mathrm{S}, \mathrm{Cu}, \mathrm{H}$ & $\begin{array}{l}\mathrm{Ca}, \mathrm{Na}, \mathrm{K}, \mathrm{CO}_{2}, \mathrm{TOC} \\
\mathrm{Ba}, \mathrm{Sr}, \mathrm{Zn}, \mathrm{Cr}, \mathrm{La}, \mathrm{Ni}, \mathrm{Rb}, \mathrm{V}, \\
\mathrm{As}, \mathrm{Sb}\end{array}$ \\
\hline ПIa & $\mathrm{Ab}-\mathrm{Ch}-\mathrm{Ms}-\mathrm{Py}$ & Si, Mg, Al, H, Na, Mn, S & $\begin{array}{l}\mathrm{Ca}, \mathrm{K}, \mathrm{CO}_{2}, \mathrm{TOC}, \mathrm{Ba}, \mathrm{Sr}, \mathrm{Rb}, \\
\mathrm{Cu}, \mathrm{Sb}\end{array}$ \\
\hline IIIa & An-Il-Py-Ba & $\begin{array}{c}\mathrm{Mg}, \mathrm{Fe}^{2+}, \mathrm{Al}, \mathrm{K}, \mathrm{H}, \mathrm{S}, \mathrm{Ba} \\
\mathrm{Cu}, \mathrm{Zn}, \mathrm{As}, \mathrm{Sb}, \mathrm{Rb}, \mathrm{V}\end{array}$ & $\mathrm{Ca}, \mathrm{Fe}^{3+}, \mathrm{Na}, \mathrm{CO}_{2}, \mathrm{Sr}$ \\
\hline IVa & Ca-Il-Py & $\begin{array}{l}\mathrm{Ca}, \mathrm{CO}_{2}, \mathrm{Mg}, \mathrm{H}, \mathrm{S}, \mathrm{Fe}^{2+}, \\
\mathrm{Mn}, \mathrm{Sr}, \mathrm{Zn}\end{array}$ & $\begin{array}{l}\mathrm{Fe}^{3+}, \mathrm{K}, \mathrm{Na}, \mathrm{Ba} \\
\mathrm{Cu}, \mathrm{As}, \mathrm{V}, \mathrm{Rb}, \mathrm{Cr}\end{array}$ \\
\hline \multicolumn{4}{|c|}{ Area of Active Venting (Site 858) } \\
\hline Ib & Qz-Wa-Ep-Py-Sp & $\mathrm{Si}, \mathrm{Al}, \mathrm{Ca}, \mathrm{H}$ & $\begin{array}{l}\mathrm{Fe}^{\mathrm{T}}, \mathrm{Na}, \mathrm{K}, \mathrm{CO}_{2}, \mathrm{TOC} \\
\mathrm{Ba}, \mathrm{Sr}, \mathrm{Rb}, \mathrm{Zn}, \mathrm{As}, \mathrm{Cu}, \\
\mathrm{Ni}, \mathrm{V}\end{array}$ \\
\hline $\mathrm{Ilb}$ & Qz-Ep-Ch & $\mathrm{Mg}, \mathrm{Na}, \mathrm{Al}, \mathrm{Fe}^{2+}, \mathrm{H}, \mathrm{Zn}, \mathrm{V}$ & $\begin{array}{l}\mathrm{Ca}, \mathrm{Fe}^{3+}, \mathrm{CO}_{2}, \mathrm{~K}, \mathrm{Ba} \text {, } \\
\mathrm{Sr}, \mathrm{As}, \mathrm{Rb}\end{array}$ \\
\hline IIIb & $\mathrm{Ab}-\mathrm{Ch}-\mathrm{Ms}-\mathrm{Py}$ & $\begin{array}{l}\mathrm{Mg}, \mathrm{Na}, \mathrm{Al}, \mathrm{Fe}^{2+}, \mathrm{H} \\
\mathrm{As}, \mathrm{Zn}, \mathrm{V}, \mathrm{Sb}\end{array}$ & $\begin{array}{l}\mathrm{Ca}, \mathrm{Fe} 3+, \mathrm{CO}_{2}, \mathrm{TOC}, \mathrm{K}, \mathrm{Ba} \\
\mathrm{Sr}, \mathrm{Rb}, \mathrm{As}, \mathrm{Sb}\end{array}$ \\
\hline IVb & An-II-Py & $\mathrm{Mg}, \mathrm{Fe}^{\mathrm{T}}, \mathrm{S}, \mathrm{Zn}, \mathrm{V}$ & $\begin{array}{l}\mathrm{Si}, \mathrm{Ca}, \mathrm{Fe}^{3+}, \mathrm{CO}_{2} \\
\mathrm{~K}, \mathrm{Ba}, \mathrm{Sr}\end{array}$ \\
\hline $\mathrm{Vb}$ & Ca-Il-Py & $\begin{array}{l}\mathrm{Ca}, \mathrm{CO}_{2}, \mathrm{Mn}, \mathrm{FeT}, \mathrm{S}, \mathrm{K} \\
\mathrm{P}, \mathrm{Ba}, \mathrm{Be}, \mathrm{Sr}, \mathrm{Sb}, \mathrm{As}, \mathrm{Se}\end{array}$ & $\mathrm{Na}, \mathrm{H}, \mathrm{Ni}$ \\
\hline VIb & $\mathrm{Sa}-\mathrm{Ta}-\mathrm{Py}$ & $\mathrm{Mg}, \mathrm{Si}, \mathrm{Fe}^{2+}, \mathrm{H}, \mathrm{Mn}, \mathrm{V}$ & $\begin{array}{l}\mathrm{K}, \mathrm{Fe}^{3+}, \mathrm{Ba}, \mathrm{Sr}, \mathrm{Zn} \text {, } \\
\mathrm{Rb}, \mathrm{Cu}\end{array}$ \\
\hline \multicolumn{4}{|c|}{ Reaction zone (Site 857) } \\
\hline Ic & Qz-Wa-Ep & $\mathrm{Si}, \mathrm{Ca}, \mathrm{Al}, \mathrm{Fe}^{3+}, \mathrm{Sr}$ & $\begin{array}{l}\mathrm{Fe}^{2+}, \mathrm{Mg}, \mathrm{Na}, \mathrm{K}, \mathrm{H}, \\
\mathrm{CO}_{2 \mathrm{~T}}, \mathrm{Ba}, \mathrm{Be}, \mathrm{Cu}, \mathrm{Zn}, \\
\mathrm{As}, \mathrm{Se}, \mathrm{Rb}, \mathrm{Ni}, \mathrm{Cr}, \mathrm{Co}\end{array}$ \\
\hline IIIc & $\mathrm{Ab}-\mathrm{Py}$ & $\mathrm{Na}, \mathrm{Fe}^{2+}, \mathrm{Ba}, \mathrm{S}, \mathrm{Zn}, \mathrm{Se}$ & $\mathrm{Fe}^{3+}, \mathrm{Ca}, \mathrm{CO}_{2}, \mathrm{Sr}$ \\
\hline
\end{tabular}

Note: $\mathrm{Qz}=$ quartz; $\mathrm{Ch}=$ chlorite; $\mathrm{Ms}=$ muscovite; $\mathrm{Ru}=$ rutile; $\mathrm{Ep}=$ epidote; $\mathrm{Wa}=$ wairkite; $\mathrm{Ab}=$ albite; $\mathrm{Sm}=$ smectite; $\mathrm{Sa}=$ saponite $\mathrm{Il}=$ illite $\mathrm{Ta}=$ talc; $\mathrm{Fp}=$ feldspar; $\mathrm{Ba}=$ barite; $\mathrm{An}=$ anhydrite; $\mathrm{Ca}=$ clacite; $\mathrm{Py}=$ pyrite; $\mathrm{Po}=$ pyrrhotite; $\mathrm{Cp}=$ chalcopyrite $; \mathrm{Sp}=$ sphalerite.

has caused massive precipitation of $\mathrm{Mg}$ from heated seawater that was locally entrained into the hydrothermal cell. The Mg-bearing minerals include $\mathrm{Mg}$-rich smectite, mixed-layer smectite-chlorite, and chlorite. At temperatures of $150^{\circ} \mathrm{C}$ and higher, $\mathrm{Mg}$ is almost completely removed from heated seawater during reaction with basalt (Mottl and Holland, 1978; Seyfried and Mottl, 1982).

The marked increase of reduced $\mathrm{S}$ in most of the alteration zones at Middle Valley suggests that Fe-bearing minerals such as magnetite and amphibole were sulfidized by hydrothermal $\mathrm{H}_{2} \mathrm{~S}$ that migrated outward from the fluid discharge conduit. The hydrothermal dissolution of biogenic and diagenetic carbonates in Zone IIb by hydrothermal fluids is reflected by a major decrease in $\mathrm{CaO}$ and $\mathrm{CO}_{2}$. The alteration zones surrounding Zone IIa consist of anhydrite-illitepyrite (Zone IIIa) and carbonate-illite-pyrite (Zone IVa). Zone IIIa is characterized by low contents of biogenic carbonate and high abundances of hydrothermal $\mathrm{Mg}$-rich clays and illite as illustrated on a $\mathrm{CaO}-\left(\mathrm{MgO}+\mathrm{Na}_{2} \mathrm{O}\right) / 2-\mathrm{K}_{2} \mathrm{O}$ ternary diagram (Fig. 24). This zone is also enriched barite and pyrite as reflected by elevated contents of $\mathrm{Ba}$,
$\mathrm{S}, \mathrm{Cu}, \mathrm{Zn}, \mathrm{Sb}$, and As. Zone IVa, the outermost zone, is characterized by hydrothermal calcite, illite, and pyrite, and is enriched in $\mathrm{Ca}, \mathrm{CO}_{2}$, $\mathrm{MgO}, \mathrm{S}, \mathrm{Fe}^{2+}, \mathrm{Mn}, \mathrm{Sr}$, and $\mathrm{Zn}$ (Table 5).

The retrograde solubility of anhydrite (Blount and Dickson, 1969) and the low $\mathrm{SO}_{4}$ contents in end-member, high-temperature seafloor hydrothermal fluids (e.g., Edmond and Von Damm, 1985; Von Damm et al., 1985; Lydon et al., 1992; Butterfield et al., this volume) indicate that Zone IIIa probably formed by reaction between heated seawater and sediment at temperatures $>150^{\circ} \mathrm{C}$. The high $\mathrm{S}, \mathrm{Cu}, \mathrm{Mo}, \mathrm{As}$, and $\mathrm{Sb}$ abundances in this zone indicate that hydrothermal fluids flowed outward from the center of fluid upflow. Elevated metal contents in Zone IVa also indicate a hydrothermal metal contribution to this alteration zone.

\section{AAV (Site 858)}

The AAV and $\mathrm{BH}$ fluid upflow zones are morphologically and textually similar. The inner core (Zone $\mathrm{Ib}$ in the AAV) is characterized 

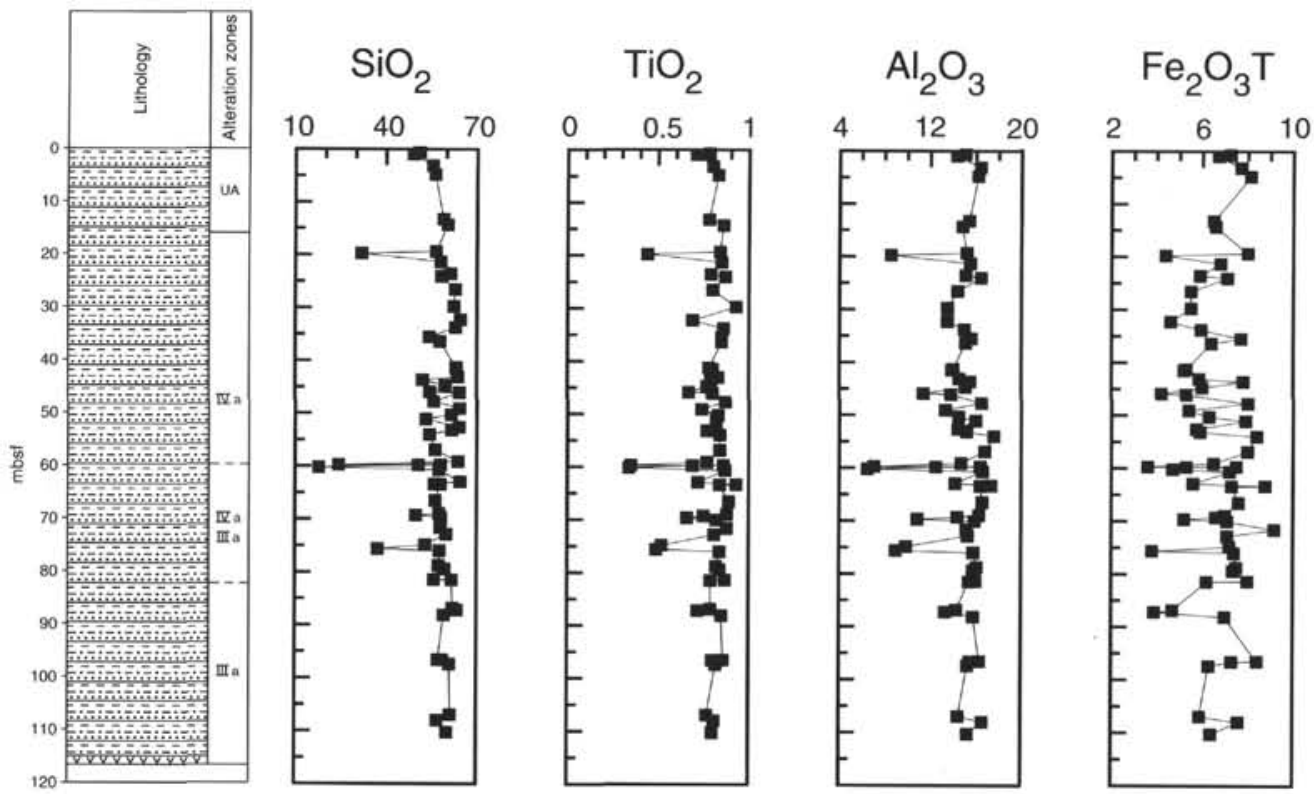

$\mathrm{P}_{2} \mathrm{O}_{5}$
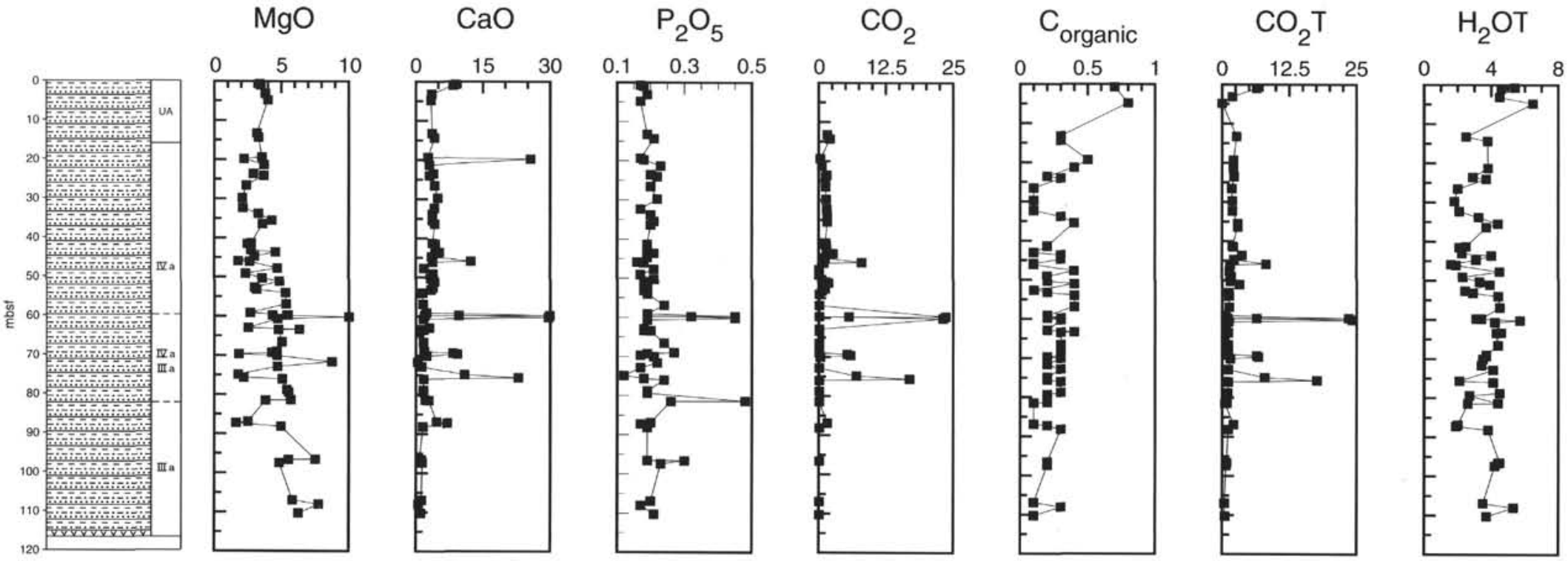

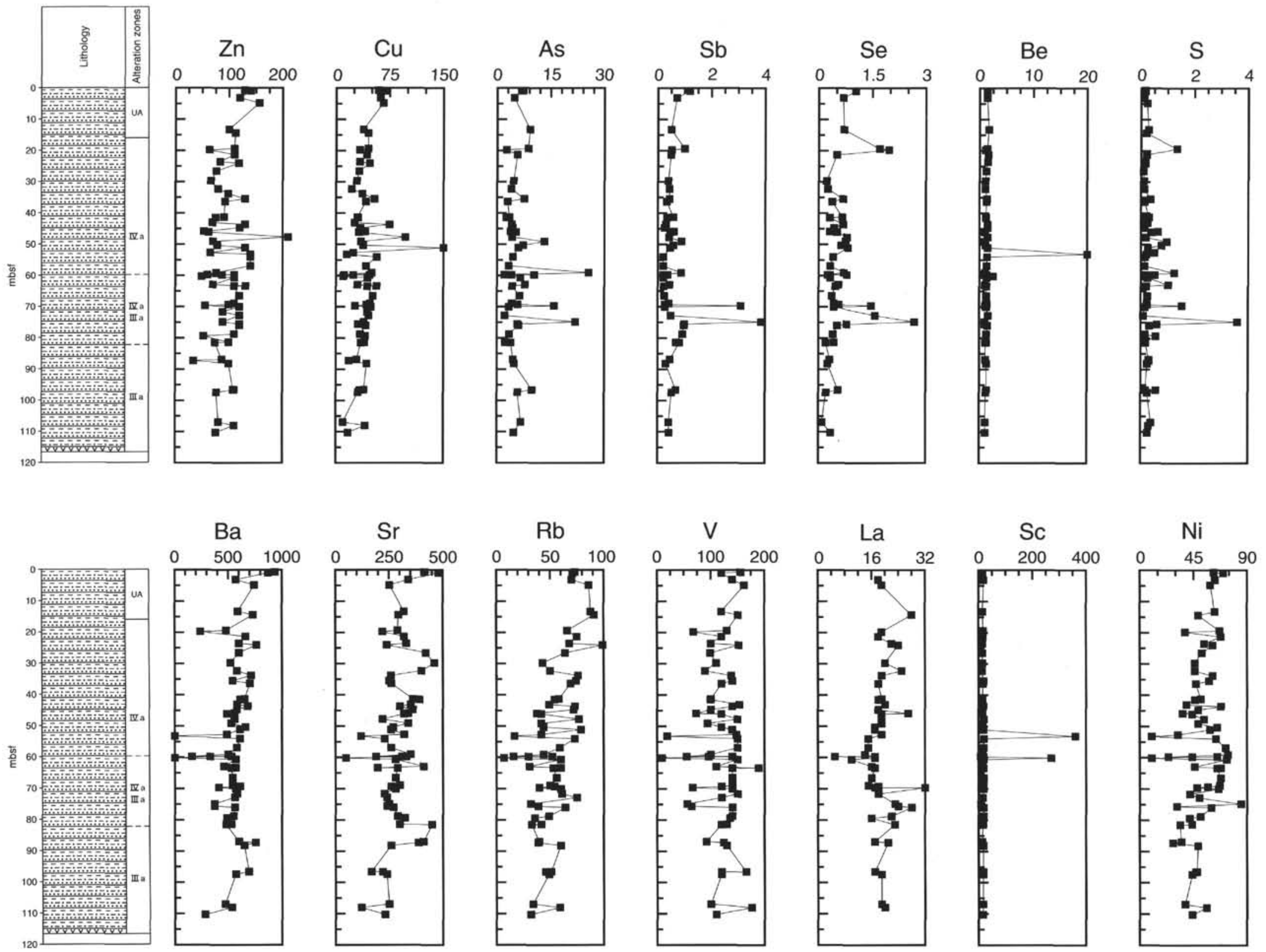

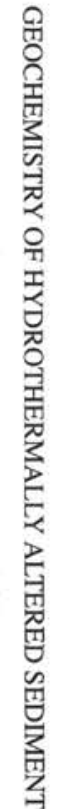

Figure 18B. Downhole profiles of minor and trace element bulk compositions for altered and unaltered hemipelagic and turbiditic sediments, Hole 856A. 

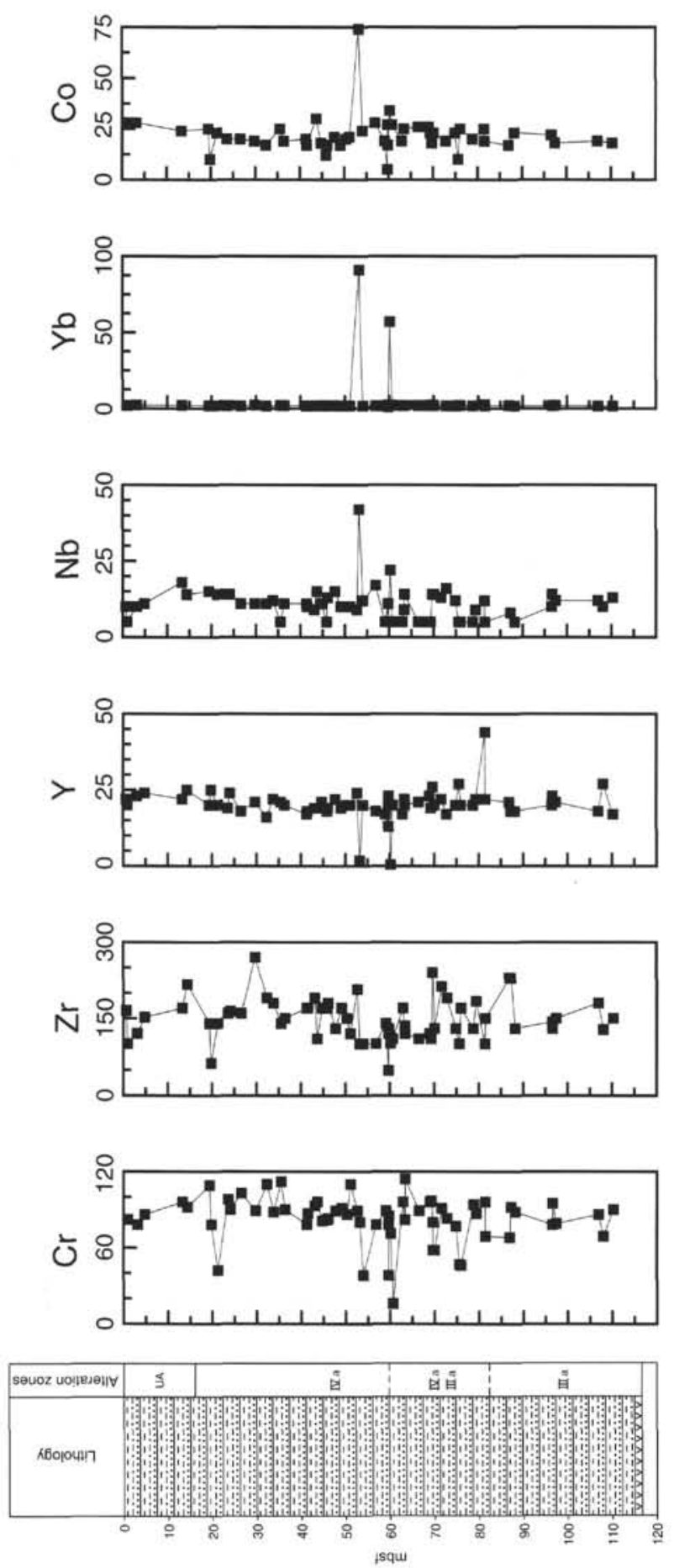

by highly lithified, fractured, and brecciated hemipelagic and turbiditic sediment. Many of the fractures are filled to varying degrees with hydrothermal quartz, wairakite, epidote, and sulfides. These minerals have also been precipitated in the interstices between detrital grains in turbiditic sandstone and siltstone. Zone $\mathrm{Ib}$, which occurs at two depth intervals within Hole $858 \mathrm{~F}$, may be a stratabound zone that formed by the lateral flow of hydrothermal fluids from a vertical or near-vertical fluid-discharge conduit. The proximity of Hole $858 \mathrm{~F}$ to active vents (Fig. 4) is consistent with this interpretation (Goodfellow and Franklin, 1993).

The sediments surrounding Zones Ib and IIb are also highly indurated and are locally fractured and veined (Zone IIIl). Zone IVb, which surrounds Zone IIIb, is characterized by moderately indurated sediments that contain anhydrite, clays, and pyrite that both replace hemipelagic sediment and infill the interstices between detrital grains (Leybourne and Goodfellow, this volume). The outer margin of Zone IVb marks the boundary between soft and indurated sediment, and has high contents of carbonate cement and concretions (Zone $\mathrm{Vb}$ ). The base of Zone $\mathrm{Vb}$ in Hole $858 \mathrm{C}$ consists of carbonate hydrothermal breccia composed of breccia clasts and calcite-cemented hemipelagic sediment (Fig. 12). Zone VIb was only intersected in Hole 858B, which was collared within several meters of an active vent (Fig. 4). The sediment below $24 \mathrm{mbsf}$ (Zone VIb) is moderately indurated, brecciated, and pervasively replaced by hydrothermal Mg-rich silicates.

The alteration assemblages in the core of the AAV upflow zone are distinct from those in the core of the $\mathrm{BH}$ discharge conduit. Unlike Zone Ia-1 at BH, Zone Ib, which is within the center of hydrothermal fluid upflow, is characterized by wairakite, epidote, and quartz. Hydrothermal calcic plagioclase has also been observed in one thin section (Leybourne and Goodfellow, this volume). Except for detrital quartz that is commonly overgrown by hydrothermal quartz, all sedimentary minerals are replaced by wairakite and epidote. The intergrowth of wairakite, epidote, and quartz in veins indicate that these minerals were coprecipitated. The $\mathrm{Ca}$-rich nature of this hydrothermal assemblage is reflected by bulk compositions that plot near the $\mathrm{CaO}$ apex along the $\mathrm{CaO}-\left(\mathrm{MgO}+\mathrm{Na}_{2} \mathrm{O}\right) / 2$ axis on $\mathrm{a}\left(\mathrm{MgO}+\mathrm{Na}_{2} \mathrm{O}\right)$ $-\mathrm{K}_{2} \mathrm{O}$ - $\mathrm{CaO}$ ternary plot (Fig. 25). The composition of samples from Zone $\mathrm{Ib}$ is distinctly different from the core of the $\mathrm{BH}$ upflow zone (Zone Ia-1), which is less calcic and plots along the $\left(\mathrm{MgO}+\mathrm{Na}_{2} \mathrm{O}\right) / 2$ - $\mathrm{K}_{2} \mathrm{O}$ axis (Fig. 24).

The Mg-poor nature of Zone Ib indicates that hydrothermal minerals were precipitated from end-member, hydrothermal fluid essentially devoid of $\mathrm{Mg}$ and similar to vent fluids at AAV (Lydon et al., 1992; Butterfield et al., this volume). Fluid inclusion temperatures for quartz from Zone $\mathrm{Ib}$ at the $\mathrm{AAV}\left(270^{\circ}\right.$ to $288^{\circ} \mathrm{C}$; Peter et al., this volume) are similar to measured temperatures $\left(184^{\circ}\right.$ to $\left.276^{\circ} \mathrm{C}\right)$ for hydrothermal vent fluids at this site (Goodfellow and Franklin, 1993). Furthermore, the occurrence of Zone Ib vertically below an active vent field and the similarity of ${ }^{87} \mathrm{Sr} /{ }^{86} \mathrm{Sr}$ ratios in Zone $\mathrm{Ib}(0.704853$; W.D. Goodfellow, unpubl. data) and AAV average vent fluids (0.70424; Butterfield et al., this volume) also suggest that the quartz-wairakiteepidote assemblage formed from hydrothermal fluids similar to those now venting at the AAV.

The composition of end-member hydrothermal fluids from AAV was plotted on a logarithmic activity phase diagram for the system $\mathrm{CaO}-\mathrm{Al}_{2} \mathrm{O}_{3}-\mathrm{SiO}_{2}-\mathrm{H}_{2} \mathrm{O}$ at $275^{\circ} \mathrm{C}$ and 500 bars using the computer program PTAX (Brown et al., 1988A, B) and the internally consistent thermodynamic database of Berman (1988) (Fig. 26). The coexistence of epidote and wairakite with quartz in Zone $\mathrm{Ib}$ indicates that fluids in equilibrium with this mineral assemblage should be restricted to a narrow range of $\log a \mathrm{Ca}^{2+} / a 2 \mathrm{H}^{+}$and $\log a \mathrm{SiO}_{2}$ (aqueous). However, measured $\log a \mathrm{SiO}_{2}$ (aqueous) values (Lydon et al., 1992; Butterfield et al., this volume) are considerably greater than equilibrium values and indicate that the fluids venting at AAV are supersaturated with respect to quartz. Silica supersaturation is common in vent fluids (e.g., Von Damm et al., 1985) because of the sluggish kinetics of quartz precipitation (Bowers et al., 1985; Seyfried et al., 1991). The log $a \mathrm{Ca}^{2+} / a 2 \mathrm{H}^{+}$ 
Table 6. Relative gains and losses ( $\left.\log \mathrm{W}_{\mathrm{B}} / \mathrm{W}_{\mathrm{A}}\right)$ of elements in representative samples from hydrothermal alteration zones associated with the BH and AAV fluid upflow conduits, and the reaction zones below $450 \mathrm{mbsf}$ at Site 857 .

\begin{tabular}{|c|c|c|c|c|c|c|c|c|c|c|c|c|c|c|c|c|c|c|c|c|c|c|}
\hline Location & Sample number & Zone & $\mathrm{Fv}\left(\mathrm{TiO}_{2}\right)$ & $\mathrm{Fv}(\mathrm{Yb})$ & Density & $\mathrm{SiO}_{2}$ & $\mathrm{TiO}_{2}$ & $\mathrm{Al}_{2} \mathrm{O}_{3}$ & $\mathrm{Fe}_{2} \mathrm{O}_{3} \mathrm{~T}$ & $\mathrm{Fe}_{2} \mathrm{O}_{3}$ & $\mathrm{FeO}$ & $\mathrm{MnO}$ & $\mathrm{MgO}$ & $\mathrm{CaO}$ & $\mathrm{Na}_{2} \mathrm{Oc}$ & $\mathrm{K}_{2} \mathrm{O}$ & $\mathrm{P}_{2} \mathrm{O}_{5}$ & $\mathrm{H}_{2} \mathrm{OT}$ & $\mathrm{S}$ & $\mathrm{CO}_{2} \mathrm{~T}$ & $\mathrm{CO}_{2}$ & TOC \\
\hline $\begin{array}{l}\text { Site } 856 \\
\text { (Bent Hill) }\end{array}$ & $\begin{array}{l}856 \mathrm{~A}-8 \mathrm{H}-01,8-10 \mathrm{~cm} \\
856 \mathrm{~B}-6 \mathrm{H}-6,118-122 \mathrm{~cm} \\
856 \mathrm{~B}-13 \mathrm{X}-4,128-132 \mathrm{~cm} \\
856 \mathrm{~B}-15 \mathrm{X}-6,6-8 \mathrm{~cm} \\
856 \mathrm{~B}-15 \mathrm{X}-1,91-93 \mathrm{~cm}\end{array}$ & $\begin{array}{l}\mathrm{IVa} \\
\mathrm{IIIa} \\
\mathrm{IIa} \\
\mathrm{Ia}-2 \\
\mathrm{Ia}-1\end{array}$ & $\begin{array}{l}1.21 \\
1.00 \\
1.03 \\
1.08 \\
1.24\end{array}$ & $\begin{array}{l}0.94 \\
1.16 \\
1.17 \\
1.03 \\
1.75\end{array}$ & $\begin{array}{l}2.78 \\
2.77 \\
2.92 \\
2.80 \\
0.18\end{array}$ & $\begin{array}{r}-0.03 \\
0.02 \\
0.08 \\
0.01 \\
0.18\end{array}$ & $\begin{array}{r}-0.06 \\
0.03 \\
0.03 \\
-0.10 \\
0.08\end{array}$ & $\begin{array}{r}-0.53 \\
0.06 \\
0.06 \\
-0.02 \\
0.19\end{array}$ & $\begin{array}{r}-0.07 \\
0.10 \\
0.00 \\
0.01 \\
0.48\end{array}$ & $\begin{array}{r}-0.57 \\
-0.49 \\
\text { ND } \\
-0.19 \\
\text { ND }\end{array}$ & $\begin{array}{l}0.05 \\
0.23 \\
\text { ND } \\
0.07 \\
\text { ND }\end{array}$ & $\begin{array}{r}0.54 \\
0.04 \\
0.90 \\
-0.32 \\
0.61\end{array}$ & $\begin{array}{l}0.20 \\
0.30 \\
0.34 \\
0.48 \\
0.25\end{array}$ & $\begin{array}{r}0.45 \\
-1.00 \\
-0.96 \\
-6.54 \\
-1.13\end{array}$ & $\begin{array}{r}-0.06 \\
-0.30 \\
0.13 \\
-1.22 \\
-1.39\end{array}$ & $\begin{array}{r}-0.22 \\
0.22 \\
-0.32 \\
-1.26 \\
0.17\end{array}$ & $\begin{array}{r}0.24 \\
0.04 \\
0.05 \\
0.09 \\
-0.08\end{array}$ & $\begin{array}{r}0.06 \\
0.24 \\
0.20 \\
0.39 \\
-3.32\end{array}$ & $\begin{array}{l}0.44 \\
0.74 \\
0.74 \\
0.76 \\
1.10\end{array}$ & $\begin{array}{l}0.61 \\
-0.11 \\
-0.46 \\
-0.60 \\
-0.35\end{array}$ & $\begin{array}{r}0.94 \\
-2.81 \\
-2.78 \\
-1.21 \\
-2.66\end{array}$ & $\begin{array}{r}-0.14 \\
0.04 \\
-0.41 \\
-0.45 \\
-0.29\end{array}$ \\
\hline $\begin{array}{l}\text { Site } 858 \\
\text { (AAV) }\end{array}$ & $\begin{array}{l}858 \mathrm{~B}-5 \mathrm{H}-01,140-143 \mathrm{~cm} \\
855 \mathrm{C}-3 \mathrm{H}-1,78-81 \mathrm{~cm} \\
858 \mathrm{~A}-18 \mathrm{X}-3,14-16 \mathrm{~cm} \\
858 \mathrm{~A}-30 \mathrm{X}-1,67-70 \mathrm{~cm} \\
858 \mathrm{~F}-25 \mathrm{R}-1,19-21 \mathrm{~cm} \\
858 \mathrm{~F}-9 \mathrm{R}-1,18-20 \mathrm{~cm}\end{array}$ & $\begin{array}{l}\mathrm{Vlb} \\
\mathrm{Vb} \\
\mathrm{IVb} \\
\mathrm{IIIb} \\
\mathrm{IIb} \\
\mathrm{Ib}\end{array}$ & $\begin{array}{l}1.50 \\
4.77 \\
0.98 \\
0.90 \\
0.95 \\
1.75\end{array}$ & $\begin{array}{l}2.27 \\
4.04 \\
0.87 \\
1.15 \\
1.26 \\
1.35\end{array}$ & $\begin{array}{l}2.67 \\
2.70 \\
2.86 \\
2.79 \\
2.70 \\
2.70\end{array}$ & $\begin{array}{r}0.10 \\
0.04 \\
-0.06 \\
-0.01 \\
0.01 \\
0.27\end{array}$ & $\begin{array}{r}0.09 \\
-0.04 \\
-0.03 \\
0.05 \\
0.06 \\
-0.56\end{array}$ & $\begin{array}{l}0.04 \\
0.04 \\
0.02 \\
0.06 \\
0.08 \\
0.09\end{array}$ & $\begin{array}{r}0.02 \\
0.15 \\
0.08 \\
0.05 \\
0.06 \\
-0.39\end{array}$ & $\begin{array}{r}-0.90 \\
\text { ND } \\
-0.54 \\
-0.98 \\
-0.66 \\
-0.82\end{array}$ & $\begin{array}{r}0.07 \\
\text { ND } \\
0.21 \\
0.21 \\
0.19 \\
-0.27\end{array}$ & $\begin{array}{r}0.60 \\
1.23 \\
0.18 \\
0.21 \\
0.26 \\
-0.30\end{array}$ & $\begin{array}{r}1.14 \\
0.03 \\
0.31 \\
0.26 \\
0.34 \\
-0.40\end{array}$ & $\begin{array}{r}-0.03 \\
1.68 \\
-0.51 \\
-0.41 \\
-0.33 \\
0.43\end{array}$ & $\begin{array}{r}-0.11 \\
-0.19 \\
-0.11 \\
0.14 \\
0.18 \\
-0.70\end{array}$ & $\begin{array}{r}-0.95 \\
0.15 \\
-0.07 \\
-0.16 \\
-0.32 \\
-1.36\end{array}$ & $\begin{array}{r}-0.20 \\
0.75 \\
0.01 \\
0.08 \\
0.01 \\
-0.01\end{array}$ & $\begin{array}{r}0.76 \\
-5.87 \\
0.24 \\
0.18 \\
0.20 \\
0.30\end{array}$ & $\begin{array}{r}-0.28 \\
1.63 \\
0.29 \\
0.29 \\
-0.24 \\
-0.75\end{array}$ & $\begin{array}{r}0.03 \\
1.92 \\
-0.19 \\
-0.26 \\
-0.29 \\
-0.57\end{array}$ & $\begin{array}{r}\mathrm{ND} \\
2.30 \\
-2.86 \\
-2.83 \\
-2.81 \\
-2.66\end{array}$ & $\begin{array}{r}\text { ND } \\
0.16 \\
-0.19 \\
-0.16 \\
-0.14 \\
-0.30\end{array}$ \\
\hline Site 857 & $\begin{array}{l}857 \mathrm{C}-21 \mathrm{R}-3,27-29 \mathrm{~cm} \\
857 \mathrm{D}-17 \mathrm{R}-3,23-25 \mathrm{~cm}\end{array}$ & $\begin{array}{l}\text { IIIc } \\
\text { Ic }\end{array}$ & $\begin{array}{l}1.12 \\
1.96\end{array}$ & $\begin{array}{l}1.17 \\
1.61\end{array}$ & $\begin{array}{l}2.60 \\
2.82\end{array}$ & $\begin{array}{l}0.04 \\
0.34\end{array}$ & $\begin{array}{r}0.01 \\
-0.04\end{array}$ & $\begin{array}{l}0.06 \\
0.13\end{array}$ & $\begin{array}{l}0.06 \\
0.07\end{array}$ & $\begin{array}{r}-0.12 \\
0.43\end{array}$ & $\begin{array}{r}0.11 \\
-0.25\end{array}$ & $\begin{array}{l}0.04 \\
0.34\end{array}$ & $\begin{array}{r}0.01 \\
-0.05\end{array}$ & $\begin{array}{r}-0.17 \\
0.62\end{array}$ & $\begin{array}{r}0.16 \\
-0.92\end{array}$ & $\begin{array}{r}0.03 \\
-1.28\end{array}$ & $\begin{array}{l}0.08 \\
0.00\end{array}$ & $\begin{array}{l}0.02 \\
0.01\end{array}$ & $\begin{array}{l}-0.08 \\
-0.12\end{array}$ & $\begin{array}{l}-0.08 \\
-0.97\end{array}$ & $\begin{aligned}-0.81 \\
\text { ND }\end{aligned}$ & $\begin{array}{l}0.04 \\
\text { ND }\end{array}$ \\
\hline Location & Sample number & Zone & $\mathrm{Fv}\left(\mathrm{TiO}_{2}\right)$ & $\mathrm{Fv}(\mathrm{Yb})$ & $\mathrm{Ba}$ & $\mathrm{Be}$ & Co & $\mathrm{Cr}$ & $\mathrm{Cu}$ & $\mathrm{La}$ & $\mathrm{Nb}$ & $\mathrm{Ni}$ & $\mathrm{Rb}$ & Sc & Sr & $\mathrm{v}$ & $\mathrm{Y}$ & $\mathrm{Yb}$ & $\mathrm{Zn}$ & $\mathrm{Zr}$ & $\mathrm{Se}$ & $\mathrm{Sb}$ \\
\hline $\begin{array}{l}\text { Site } 856 \\
\text { (Bent Hill) }\end{array}$ & $\begin{array}{l}856 \mathrm{~A}-8 \mathrm{H}-1,8-10 \mathrm{~cm} \\
856 \mathrm{~B}-6 \mathrm{H}-6,118-122 \mathrm{~cm} \\
856 \mathrm{~B}-13 \mathrm{X}-4,128-132 \mathrm{~cm} \\
856 \mathrm{~B}-15 \mathrm{X}-6,6-8 \mathrm{~cm} \\
856 \mathrm{~B}-15 \mathrm{X}-1,91-93 \mathrm{~cm}\end{array}$ & $\begin{array}{l}\text { IVa } \\
\text { IIIa } \\
\text { Ila } \\
\text { la-2 } \\
\text { la-1 }\end{array}$ & $\begin{array}{l}1.21 \\
1.00 \\
1.03 \\
1.08 \\
1.24\end{array}$ & $\begin{array}{l}0.94 \\
1.16 \\
1.17 \\
1.03 \\
1.75\end{array}$ & $\begin{array}{r}-0.14 \\
0.07 \\
-0.14 \\
-0.96 \\
0.14\end{array}$ & $\begin{array}{r}-0.04 \\
0.07 \\
0.03 \\
-0.27 \\
0.06\end{array}$ & $\begin{array}{r}-0.01 \\
0.12 \\
0.07 \\
-0.85 \\
0.23\end{array}$ & $\begin{array}{r}-0.10 \\
0.02 \\
-0.03 \\
-1.26 \\
0.06\end{array}$ & $\begin{array}{r}-0.19 \\
0.07 \\
-0.23 \\
1.12 \\
1.88\end{array}$ & $\begin{array}{r}0.04 \\
0.01 \\
-0.01 \\
-0.50 \\
0.07\end{array}$ & $\begin{array}{r}-0.35 \\
0.19 \\
0.27 \\
0.16 \\
-0.20\end{array}$ & $\begin{array}{r}-0.09 \\
0.07 \\
-0.06 \\
-1.03 \\
0.01\end{array}$ & $\begin{array}{r}-0.20 \\
0.24 \\
-0.28 \\
-0.98 \\
-0.12\end{array}$ & $\begin{array}{r}-0.11 \\
0.06 \\
0.02 \\
-0.05 \\
0.11\end{array}$ & $\begin{array}{r}0.05 \\
-0.68 \\
-0.72 \\
-0.52 \\
-1.32\end{array}$ & $\begin{array}{r}-0.10 \\
0.07 \\
0.04 \\
-0.83 \\
0.058\end{array}$ & $\begin{array}{r}0.10 \\
0.02 \\
0.00 \\
-0.06 \\
0.09\end{array}$ & $\begin{array}{r}0.06 \\
-0.03 \\
-0.03 \\
0.010 \\
-0.08\end{array}$ & $\begin{array}{r}0.07 \\
0.25 \\
0.01 \\
-1.47 \\
0.43\end{array}$ & $\begin{array}{r}-0.03 \\
-0.02 \\
0.01 \\
-0.03 \\
0.05\end{array}$ & $\begin{array}{r}-0.45 \\
-0.30 \\
-0.61 \\
0.18 \\
0.70\end{array}$ & $\begin{array}{r}0.00 \\
0.24 \\
-0.31 \\
-0.35 \\
-0.20\end{array}$ \\
\hline $\begin{array}{l}\text { Site } 858 \\
\text { (AAV) }\end{array}$ & $\begin{array}{l}858 \mathrm{~B}-5 \mathrm{H}-1,140-143 \mathrm{~cm} \\
858 \mathrm{C}-3 \mathrm{H}-1,78-81 \mathrm{~cm} \\
858 \mathrm{~A}-18 \mathrm{X}-3,14-16 \mathrm{~cm} \\
858 \mathrm{~A}-30 \mathrm{X}-1,67-70 \mathrm{~cm} \\
858 \mathrm{~F}-25 \mathrm{R}-1,19-21 \mathrm{~cm} \\
858 \mathrm{~F}-9 \mathrm{R}-1,18-20 \mathrm{~cm}\end{array}$ & $\begin{array}{l}\mathrm{Vlb} \\
\mathrm{Vb} \\
\mathrm{IVb} \\
\mathrm{IIJ} \\
\mathrm{IIb} \\
\mathrm{Ib}\end{array}$ & $\begin{array}{l}1.50 \\
4.77 \\
0.98 \\
0.90 \\
0.95 \\
1.75\end{array}$ & $\begin{array}{l}2.27 \\
4.04 \\
0.87 \\
1.15 \\
1.26 \\
1.35\end{array}$ & $\begin{array}{r}-0.59 \\
0.36 \\
-0.27 \\
-0.37 \\
-0.27 \\
-0.81\end{array}$ & $\begin{array}{r}-0.12 \\
0.60 \\
0.02 \\
0.02 \\
0.07 \\
-0.20\end{array}$ & $\begin{array}{r}-0.12 \\
0.06 \\
-0.02 \\
0.10 \\
-0.10 \\
-0.40\end{array}$ & $\begin{array}{r}0.07 \\
0.03 \\
-0.13 \\
-0.09 \\
-0.02 \\
-0.06\end{array}$ & $\begin{array}{r}-0.35 \\
0.21 \\
0.02 \\
-0.15 \\
0.05 \\
-0.38\end{array}$ & $\begin{array}{r}0.03 \\
0.41 \\
-0.13 \\
-0.04 \\
-0.05 \\
0.16\end{array}$ & $\begin{array}{l}0.48 \\
0.56 \\
0.11 \\
0.19 \\
0.16 \\
0.40\end{array}$ & $\begin{array}{r}0.10 \\
-0.13 \\
0.01 \\
-0.07 \\
-0.10 \\
-0.33\end{array}$ & $\begin{array}{r}-0.46 \\
0.15 \\
-0.07 \\
-0.12 \\
-0.36 \\
-0.53\end{array}$ & $\begin{array}{r}0.00 \\
0.00 \\
0.03 \\
0.06 \\
0.10 \\
-0.10\end{array}$ & $\begin{array}{r}-0.42 \\
0.21 \\
-0.56 \\
-0.41 \\
-0.21 \\
-0.50\end{array}$ & $\begin{array}{r}0.22 \\
0.16 \\
0.08 \\
0.08 \\
0.13 \\
-0.15\end{array}$ & $\begin{array}{r}-0.05 \\
0.34 \\
0.06 \\
-0.05 \\
-0.01 \\
-0.01\end{array}$ & $\begin{array}{r}-0.09 \\
0.04 \\
0.03 \\
-0.05 \\
-0.06 \\
0.06\end{array}$ & $\begin{array}{r}-0.17 \\
-0.01 \\
0.08 \\
0.10 \\
0.11 \\
-0.44\end{array}$ & $\begin{array}{r}0.16 \\
-0.08 \\
-0.15 \\
-0.16 \\
-0.06 \\
0.18\end{array}$ & $\begin{array}{r}-0.72 \\
0.82 \\
0.11 \\
0.05 \\
0.32 \\
-0.80\end{array}$ & $\begin{array}{r}-0.12 \\
1.28 \\
-0.40 \\
0.27 \\
-0.34 \\
-0.20\end{array}$ \\
\hline Site 857 & $\begin{array}{l}857 \mathrm{C}-21 \mathrm{R}-3,27-29 \mathrm{~cm} \\
857 \mathrm{D}-17 \mathrm{R}-3,23-25 \mathrm{~cm}\end{array}$ & $\begin{array}{l}\text { IIIc } \\
\text { Ic }\end{array}$ & $\begin{array}{l}1.12 \\
1.96\end{array}$ & $\begin{array}{l}1.17 \\
1.61\end{array}$ & $\begin{array}{r}0.05 \\
-0.73\end{array}$ & $\begin{array}{r}0.07 \\
-0.12\end{array}$ & $\begin{array}{r}0.04 \\
-0.32\end{array}$ & $\begin{array}{l}-0.03 \\
-0.17\end{array}$ & $\begin{array}{l}-0.02 \\
-0.34\end{array}$ & $\begin{array}{l}0.04 \\
0.03\end{array}$ & $\begin{array}{l}0.07 \\
0.26\end{array}$ & $\begin{array}{l}-0.09 \\
-0.35\end{array}$ & $\begin{array}{l}-0.01 \\
-0.45\end{array}$ & $\begin{array}{r}0.01 \\
-0.06\end{array}$ & $\begin{array}{r}-0.04 \\
0.25\end{array}$ & $\begin{array}{r}0.00 \\
-0.10\end{array}$ & $\begin{array}{l}0.02 \\
0.04\end{array}$ & $\begin{aligned}-0.01 \\
0.04\end{aligned}$ & $\begin{array}{r}0.09 \\
-0.34\end{array}$ & $\begin{array}{r}-0.07 \\
0.13\end{array}$ & $\begin{array}{l}-0.20 \\
-0.32\end{array}$ & $\begin{array}{r}0.22 \\
-0.12\end{array}$ \\
\hline
\end{tabular}

Note: $\mathrm{ND}=$ not determined; $\mathrm{Fv}=$ volume factor, density $=$ grams $/ \mathrm{cm}^{2}$. 

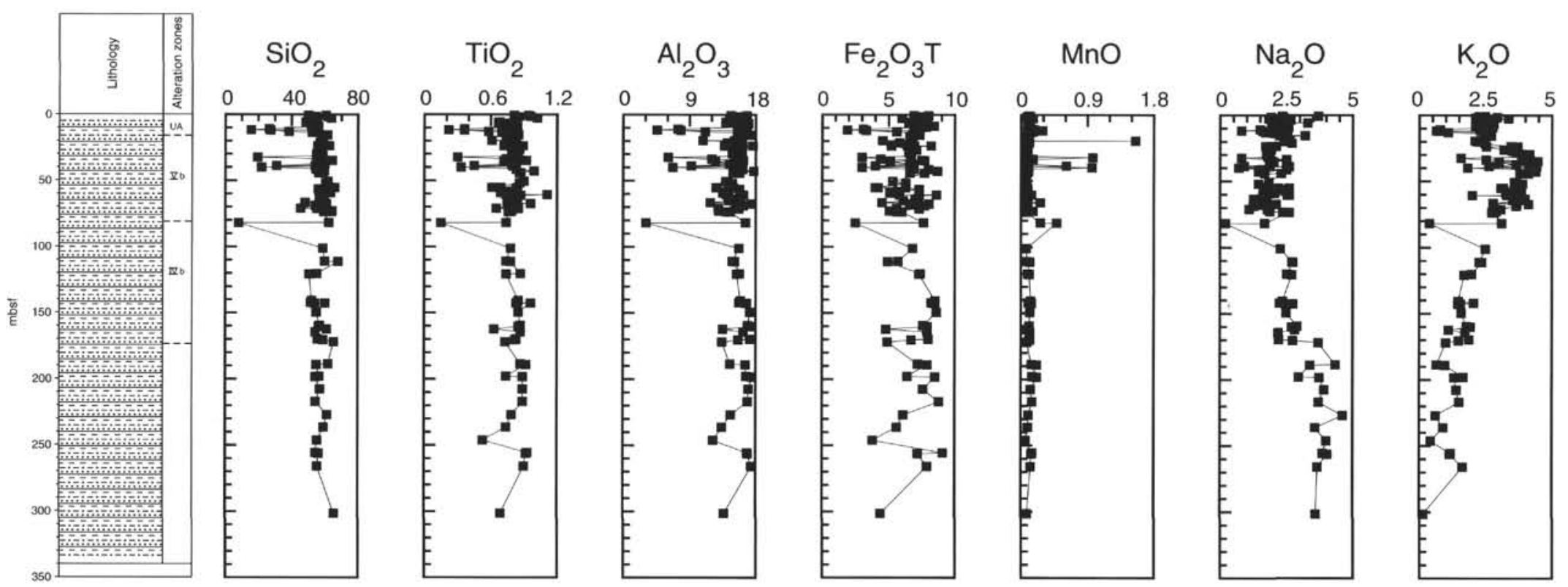

$\mathrm{MgO}$

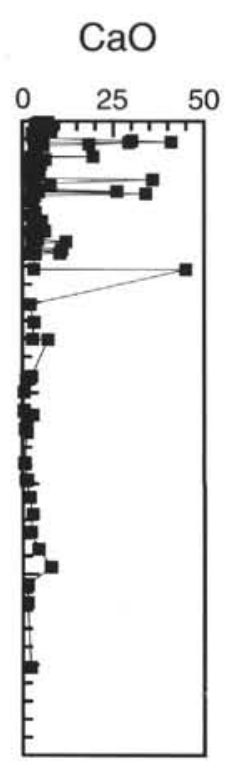

$$
\mathrm{P}_{2} \mathrm{O}_{5}
$$

$\mathrm{CO}_{2}$
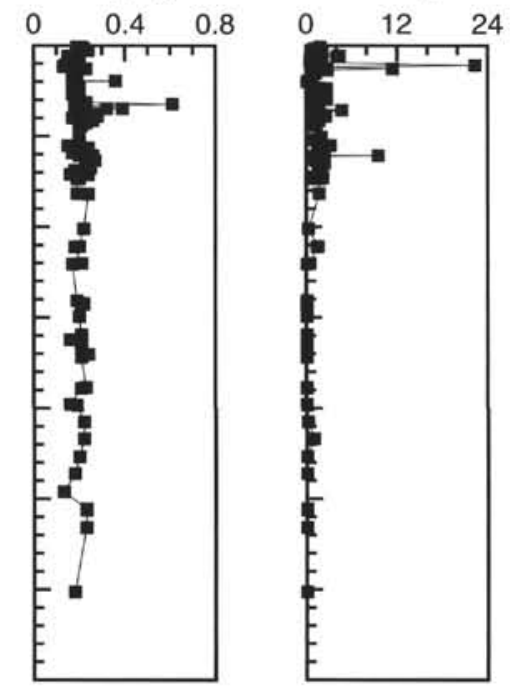

Corganic $_{\text {. }}$
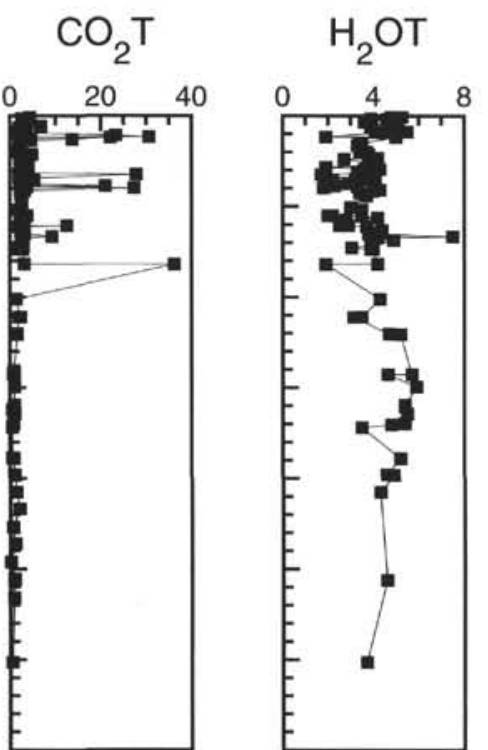

Figure 19A. Downhole profiles of major element bulk compositions for altered and unaltered hemipelagic and turbiditic sediments, Hole 858A. 

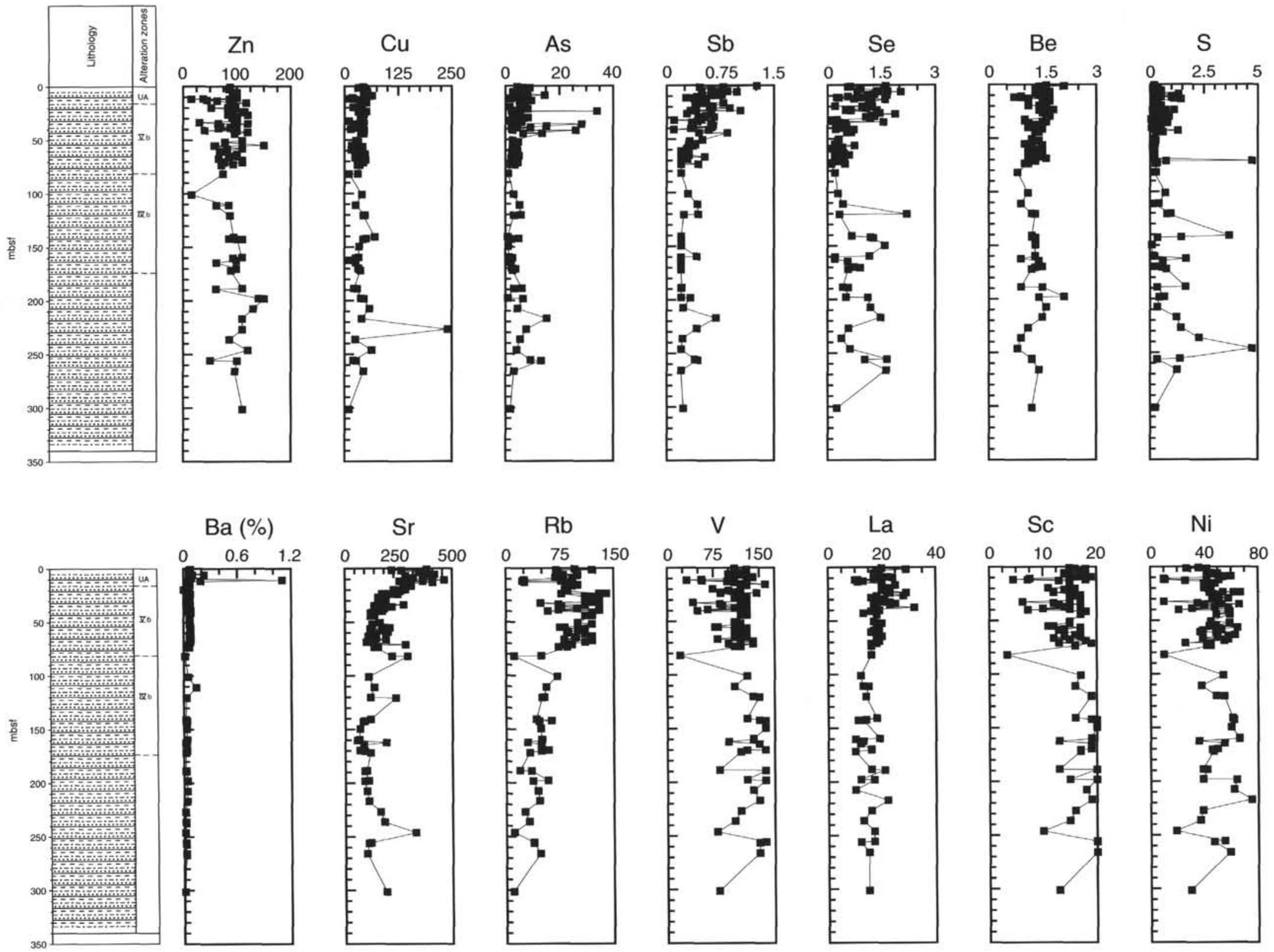

Figure 19B. Downhole profiles of minor and trace element bulk compositions for altered and unaltered hemipelagic and turbiditic sediments, Hole 858A 

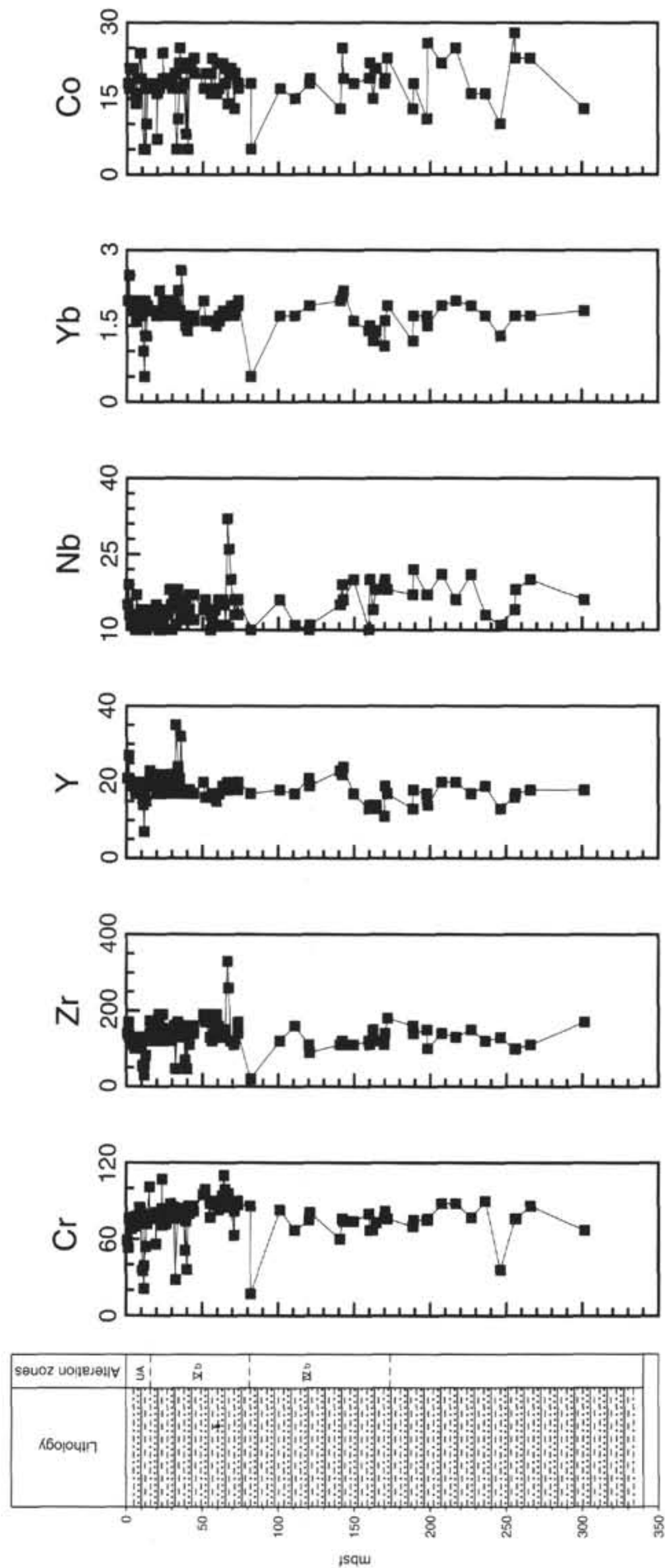

ratio of AAV fluids plots near the wairakite-clinozoisite mineral stability boundary, indicating near-equilibrium conditions for these components. AAV hydrothermal fluids have end-member $\mathrm{Ca}^{2+}$ concentrations ( $\approx 80 \mathrm{mmol}$; Lydon et al., 1992; Butterfield et al., this volume) that are double those for hydrothermal fluids vented at sediment-bare ridges (e.g., Von Damm, 1990). The high Ca content of end-member AAV hydrothermal fluids accounts for the presence of abundant $\mathrm{Ca}$ silicate minerals in Zone $\mathrm{Ib}$. Possible sources of $\mathrm{Ca}$ include biogenic carbonate and calcic plagioclase in hemipelagic and turbiditic sediments and mafic sills, and possibly $\mathrm{CaSO}_{4}$ deposited by downwelling hydrothermal fluids.

Calcium fixation is enhanced with increasing temperature provided the pressures are sufficiently low. Temperatures $>350^{\circ} \mathrm{C}$ favor the removal of $\mathrm{Ca}$ from solution, $\mathrm{H}^{+}$production, heavy metal solubilization, and the formation of epidote and, in some cases, Ca-plagioclase (Seyfried et al., 1988). Epidote-rich rocks may represent a permeable reaction zone dominated by hot, ascending hydrothermal fluids. Na fixation, in contrast to $\mathrm{Ca}$ and $\mathrm{Mg}$, is retrograde and may dominate reaction zones affected by ascending hydrothermal fluids that are cooled conductively.

Zone IIb of the AAV, which surrounds Zone Ib near the core of the upflow zone, is distinguished by a lack of wairakite and the presence of Mg-rich chlorite that replaces sedimentary feldspar, mica, and illite. The chloritization of $\mathrm{K}$-silicates is reflected by the addition of $\mathrm{Mg}$ and the depletion of $\mathrm{K}, \mathrm{Rb}, \mathrm{Ba}$, and $\mathrm{Sr}$. Copper, $\mathrm{Zn}, \mathrm{As}, \mathrm{Sb}$, and Se also are depleted in Zone IIb (Table 3) relative to unaltered hemipelagic and turbiditic sediment (Table 2). The occurrence of hydrothermal epidote and $\mathrm{Mg}$-rich chlorite in Zone IIb near the core of the AAV discharge conduit suggests that this zone formed either by (1) the mixing of entrained seawater with hydrothermal fluids or (2) the partial overprinting of a high-temperature mineral assemblage (Zone $\mathrm{Ib}$ ) by a retrograde assemblage precipitated from lower-temperature modified seawater. Zone IIIb consists of Mg-rich chlorite and albite formed by the replacement of feldspar, mica, and illite. These replacement reactions resulted in the addition of $\mathrm{Mg}$ and $\mathrm{Na}$, and depletion of $\mathrm{K}, \mathrm{Rb}, \mathrm{Ca}$, $\mathrm{Sr}$, and $\mathrm{Ba}$ (Table 3). The addition of $\mathrm{Mg}$ in Zone IIIb indicates that it formed by the reaction of heated seawater with sediment enveloping the main hydrothermal-fluid conduit.

The sulfidation of Fe-bearing minerals pyrite and amphibole, and high S, As, Sb, and Se contents in Zones IVb and Vb (Table 3) indicate that hydrothermal fluids migrated to the outermost margins of the upflow zone and precipitated sulfides along with retrograde calcite and anhydrite at lower temperatures. Other evidence for the upward and outward migration of hydrothermal fluids includes (1) positive $\delta^{34} \mathrm{~S}$ values in euhedral pyrite from Zone $\mathrm{Vb}(0.8$ to $10.6 \%)$ that approach values for massive sulfides at AAV (11.7 to 13.5\%) but are distinct from isotopically light, diagenetic S $(-12.4$ to $-39.7 \%$ ) (Goodfellow et al., 1993); and (2) ${ }^{87} \mathrm{Sr} /{ }^{86} \mathrm{Sr}$ initial ratios in calcite and barite from Zones IVb and $\mathrm{Vb}(0.7060-0.7065$; Goodfellow et al., $1993)$ that are transitional between seawater $(0.70918)$ and hydrothermal fluid $\mathrm{Sr}$ (0.7042) (Butterfield et al., this volume).

Within Zone IVb, fluid temperatures estimated from fluid inclusions in anhydrite are between $230^{\circ}$ and $311^{\circ} \mathrm{C}$ (Peter et al., this volume). These temperatures are consistent with anhydrite's retrograde solubility and precipitation from seawater at temperatures generally $>150^{\circ} \mathrm{C}$. Anhydrite in veins probably formed by the rapid heating of seawater by hydrothermal fluids nearer the core of the upflow zone.

In Zone Vb temperatures of mineral precipitation calculated using equilibrium isotope fractionation factors between calcite and fluid, and assuming a $\delta^{18} \mathrm{O}_{\mathrm{SMOW}}$ values of $0.0 \%$ for the fluid, range between $20^{\circ}$ and $180^{\circ} \mathrm{C}$ (W.D. Goodfellow, unpubl. data). These temperatures are in agreement with fluid inclusion temperatures in calcite concretions, which range between $112^{\circ}$ and $192^{\circ} \mathrm{C}$ (Peter et al., this volume),

$\delta^{13} \mathrm{C}$ values for fluids calculated from values for calcite for this zone range between -30.7 and $-35.4 \%$ (Peter et al., this volume) and are much more negative than seawater. This suggests that the hy- 

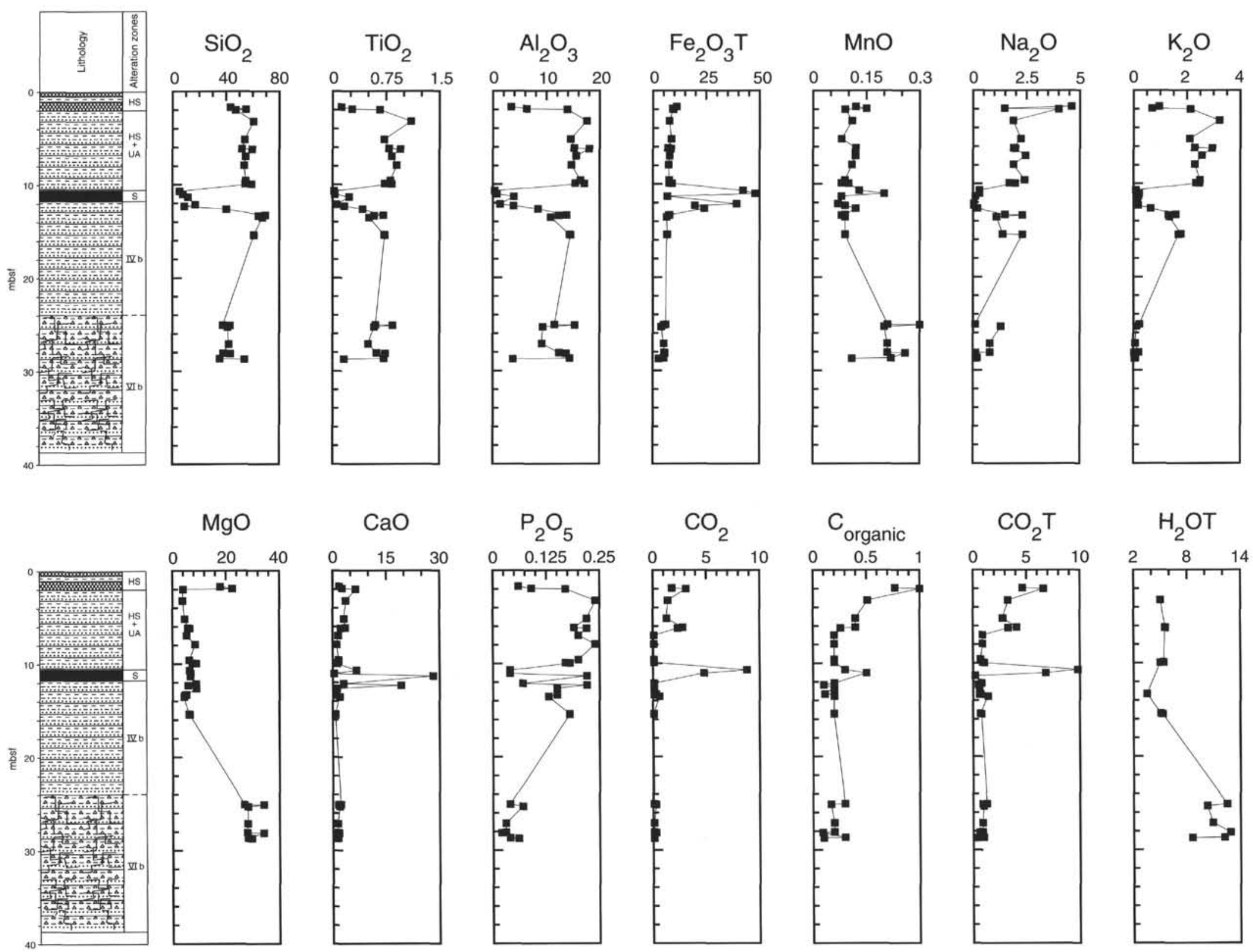

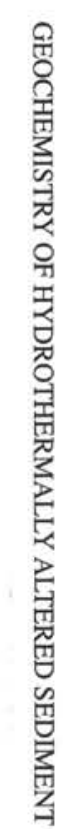



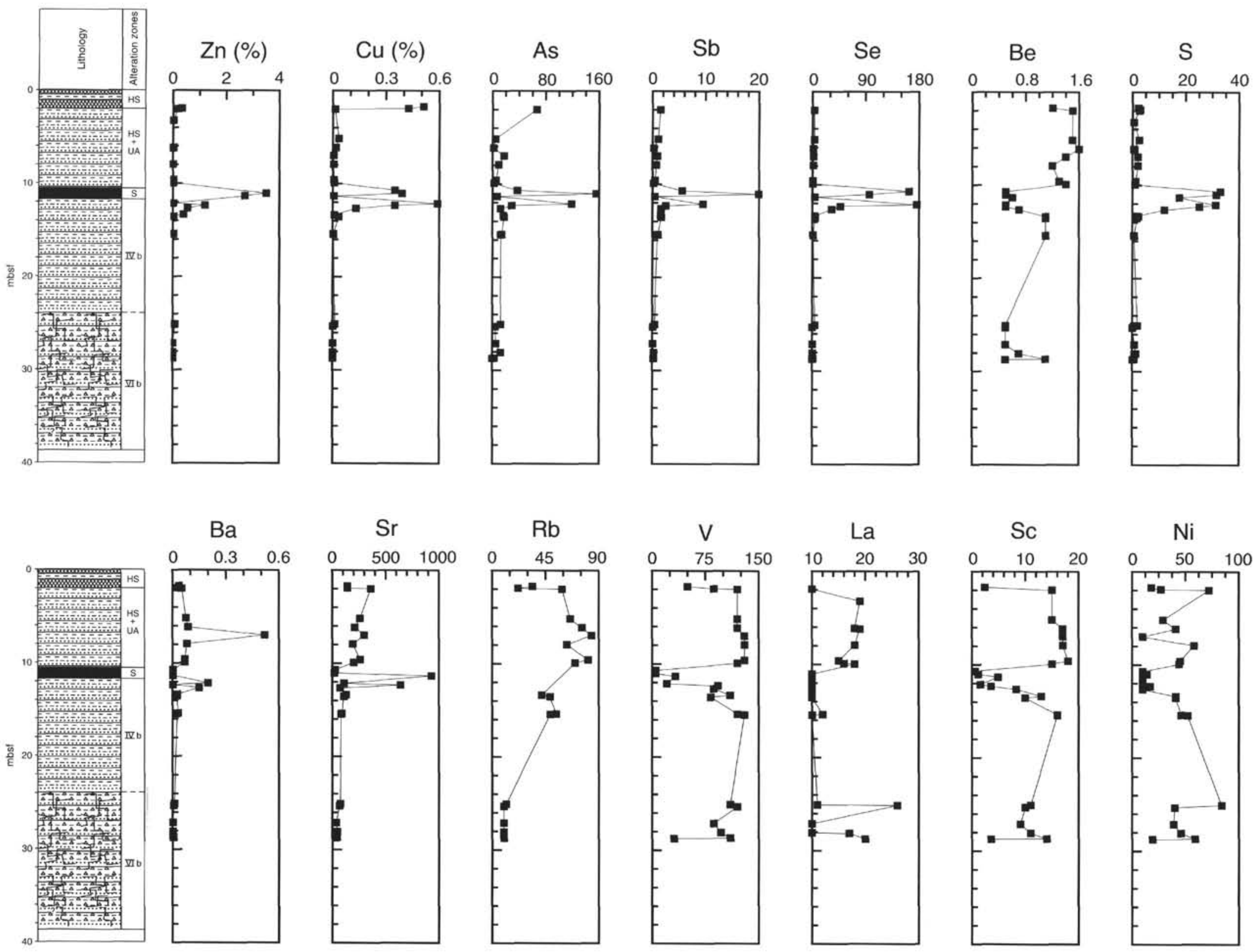

Figure 20B. Downhole profiles of minor and trace element bulk compositions for altered and unaltered hemipelagic and turbiditic sediments, Hole 858B. 

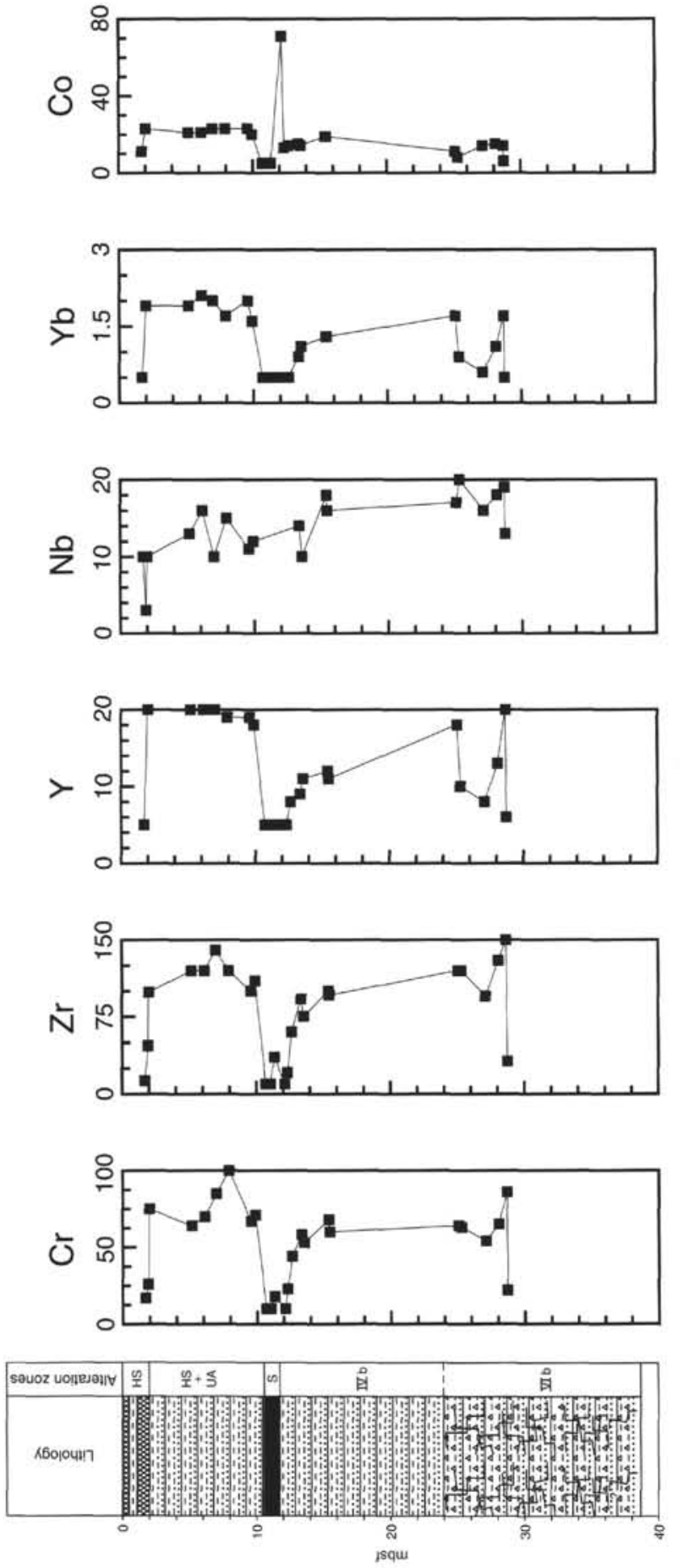

drothermal $\mathrm{CH}_{4}$ has been oxidized by methanogenic bacteria (Goodfellow et al., 1993) and/or that biogenic carbonate dissolved from the inner alteration zone has been modified by mixing with carbonate dissolved in hydrothermal fluids. If calcite precipitated from a fluid of uniform carbon and oxygen isotope composition under equilibrium conditions, $\delta^{13} \mathrm{C}$ and $\delta^{18} \mathrm{O}$ values of calcite would correlate positively, and variations would result only from variations in the temperature of precipitation. However, $\delta^{13} \mathrm{C}$ and $\delta^{18} \mathrm{O}$ values for hydrothermal calcite in shallow cores that penetrated $\mathrm{Zone} \mathrm{Vb}$ at the AAV show an inverse correlation on a plot of $\delta^{13} \mathrm{C}$ vs. $\delta^{18} \mathrm{O}$ (Goodfellow et al., 1993) that is best explained by precipitation over a narrow temperature range $\left(\approx 100^{\circ} \mathrm{C}\right)$ from a fluid of varying $\delta^{13} \mathrm{C}(-15$ to $-30 \%)$ and $\delta^{18} \mathrm{O}(+4$ to $+15 \%$ composition under equilibrium conditions. The positive correlation of $\delta^{13} \mathrm{C}$ with temperature shows that the contribution of isotopically light carbon increases away from hydrothermal vents. $\delta^{13} \mathrm{C}$ values calculated for fluids using $\delta^{13} \mathrm{C}$ values of calcite in carbonate concretions assuming equilibrium fractionation and using oxygen isotope geothermometry (assuming $\delta^{18} \mathrm{O}$ fluid $=0.0 \%$ ) vary between $-19.95 \%$ at $234^{\circ} \mathrm{C}$ and $-31.62 \%$ at $137^{\circ} \mathrm{C}$ (Peter et al., this volume). Such values are consistent with in-situ oxidation of $\mathrm{CH}_{4}$ by methanogenic bacteria at temperatures $<137^{\circ} \mathrm{C}$ near the outer margins of the fluid upflow zone (Goodfellow et al., 1993).

At shallow depths near active vents, alteration minerals in hemipelagic and turbiditic sediment are distinct from those described above for Zone $\mathrm{Vb}$. Near active vents at the AAV, alteration consists mainly of saponite in shallow $(<10 \mathrm{~m})$ sediment cores (Goodfellow et al., 1993; Turner et al., 1993). The only hole with similar alteration drilled during Leg 139 was Hole 858B (38-m depth), located within a few meters of an active vent at the AAV (Fig. 4). Stratabound sulfide-anhydrite occurs at $11 \mathrm{mbsf}$ within hemipelagic and turbiditic sediments that are crosscut by anhydrite veins to a depth of about 24 mbsf. Between 24 and $38 \mathrm{mbsf}$, the hemipelagic and turbiditic sediment is fractured, brecciated, and intensely altered to a Mg-rich clay (Zone $\mathrm{VIb}$ ). High $\mathrm{MgO}$ contents (up to $30 \mathrm{wt} \%$ ) indicate that Zone $\mathrm{VIb}$ formed by the reaction of locally recharged seawater with sediment adjacent to the hydrothermal fluid conduit. $\mathrm{A}^{87} \mathrm{Sr} /{ }^{86} \mathrm{Sr}$ value of 0.704204 (Sample 139-858B-5H-4, 27-29 cm; W.D. Goodfellow, unpubl. data) indicates that most of the $\mathrm{Sr}$ was derived from hydrothermal fluids (average ${ }^{87} \mathrm{Sr} /{ }^{86} \mathrm{Sr}=0.70424$; Butterfield et al., this volume). The minimum water/rock ratio is 133 based on a Mg content of $52.8 \mathrm{mmol} / \mathrm{kg}$ for Middle Valley seawater (Butterfield et al., this volume) and a mass gain of $\mathrm{MgO}$ in Zone VIb of $28.2 \mathrm{wt} \%$ (Table 4). Manganese, Mo, and S are enriched in Zone VIb, whereas most of the alkali elements have been depleted by the replacement of feldspar, mica, and illite by Mg-rich clay.

Temperatures in hydrothermal reaction zones calculated using mineral chemistry thermometry are generally greater than temperatures measured at the seafloor at many vent sites on the modern seafloor (Ding and Seyfried, 1989), suggesting that the fluids have cooled during transit to the seafloor. Von Damm et al. (1985) concluded that the fluids had conductively cooled at the National Geographic Society vent at $21^{\circ} \mathrm{N}$, East Pacific Rise (EPR), whereas Bowers et al. (1988) and Campbell et al. (1988) proposed that cooling of the reaction zone in the vicinity of the magma chamber accounted for the decreased temperature of vent fluids. In the case of Middle Valley, the low sulfide content of active vent fluids and their products from the AAV and south of $\mathrm{BH}$, and the upflow zone at Site 858 (Zone $\mathrm{Ib}$ ) compared with the BH upflow zone (Zone Ia-1) and its related massive sulfide deposit, suggest that the composition of the hydrothermal fluids has evolved from high-temperature, metal-rich fluids to moderate-temperature $\left(<300^{\circ} \mathrm{C}\right)$, metal-poor fluids. In the AAV, the low-metal hydrothermal system has probably been active for at least 2000 years based on the content of detrital $\mathrm{TiO}_{2}$ in $80 \mathrm{~cm}$ of hydrothermal sediment overlying hemipelagic sediment in core TUL87B-15 and assuming an ambient sedimentation rate of $11 \mathrm{~cm} \mathrm{k.y.} .^{-1}$ as determined by ${ }^{14} \mathrm{C}$ dating of Holocene foraminifers in hemipelagic sediment (Goodfellow and Franklin, 1993). The similarities between the AAV and $\mathrm{BH}$ hydrothermal fluid 

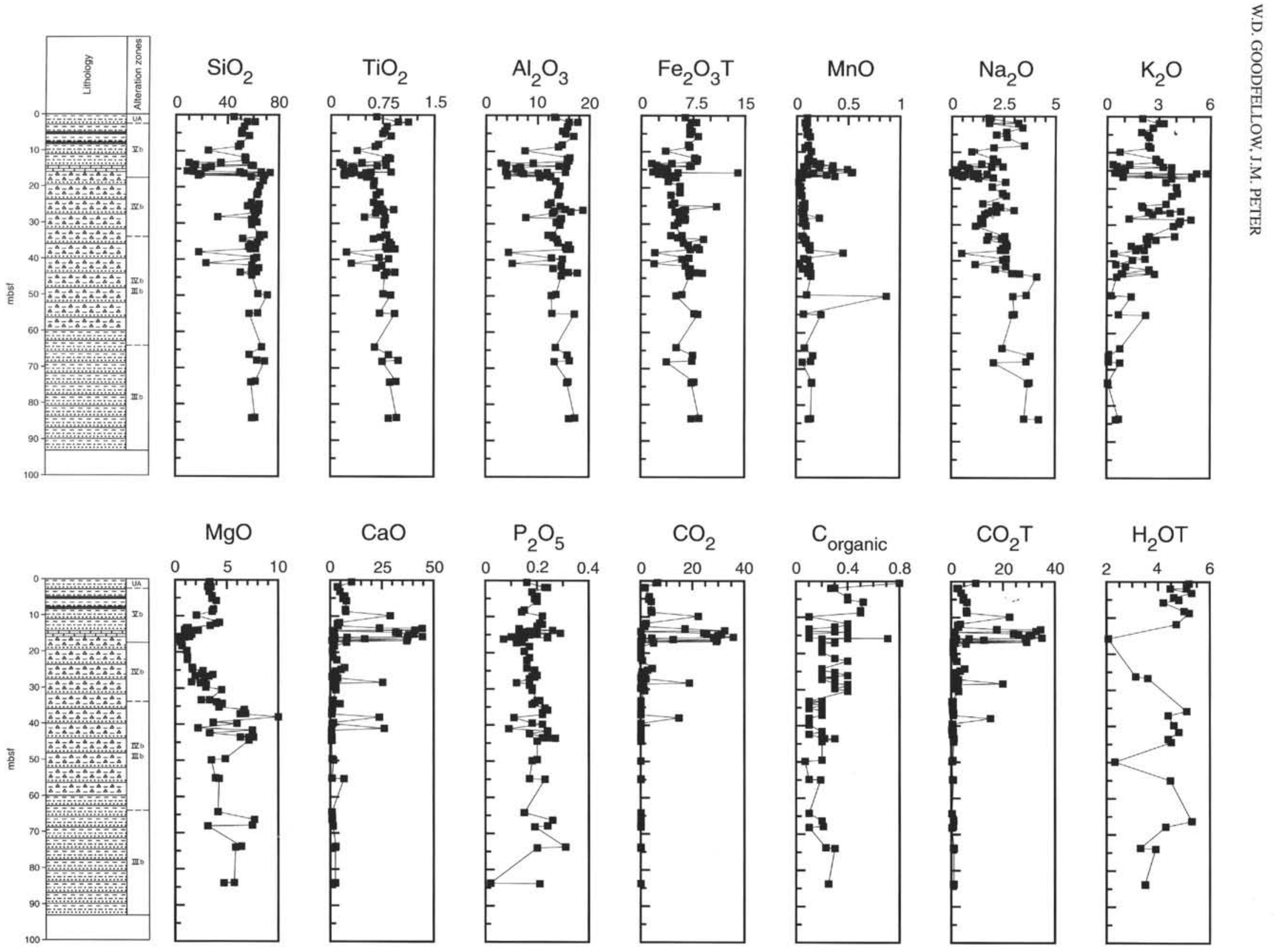

Figure 21A. Downhole profiles of major element bulk compositions for altered and unaltered hemipelagic and turbiditic sediments, Hole 858C. 

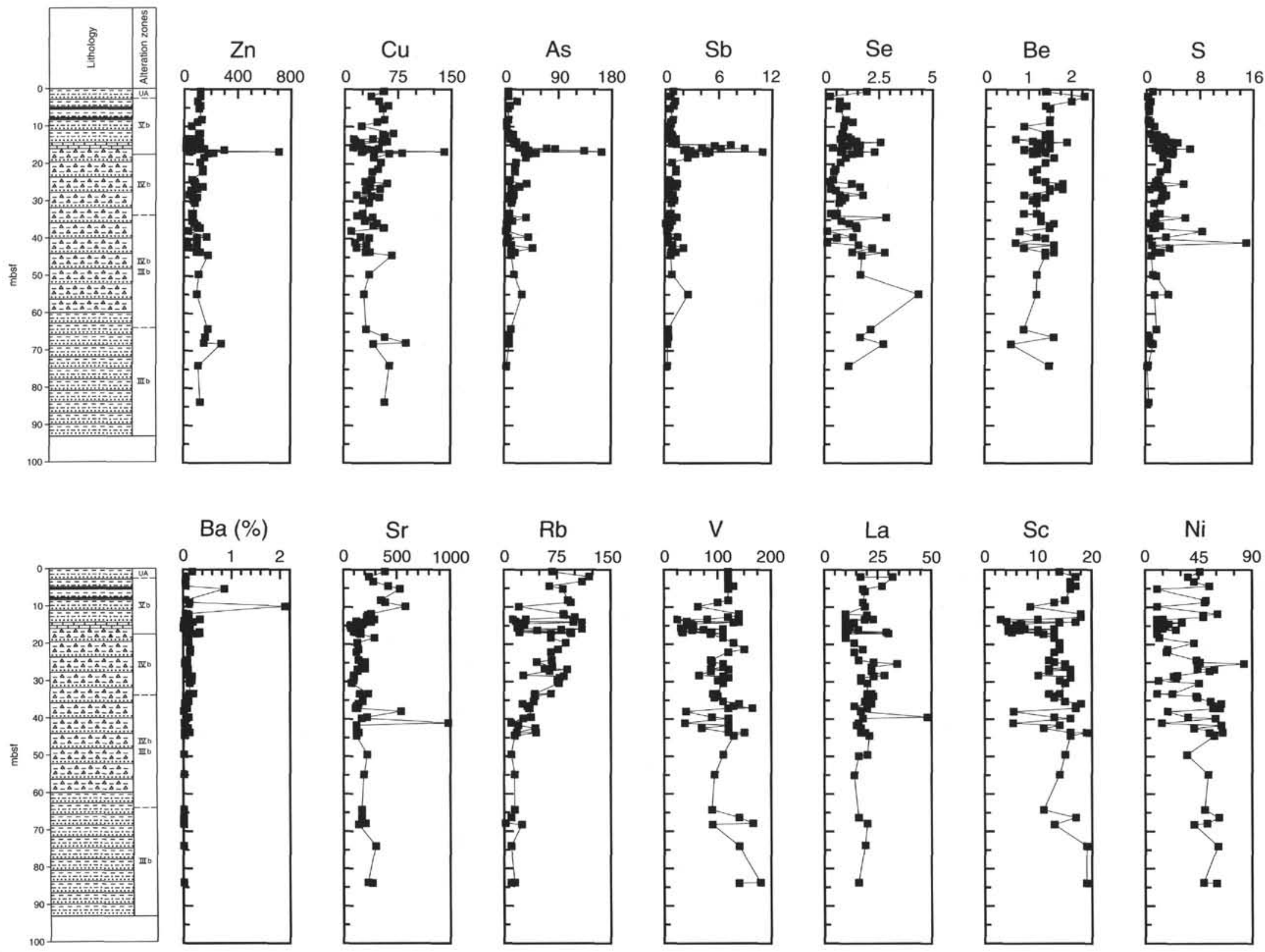

Figure 21B. Downhole profiles of minor and trace element bulk compositions for altered and unaltered hemipelagic and turbiditic sediments, Hole 858C. 

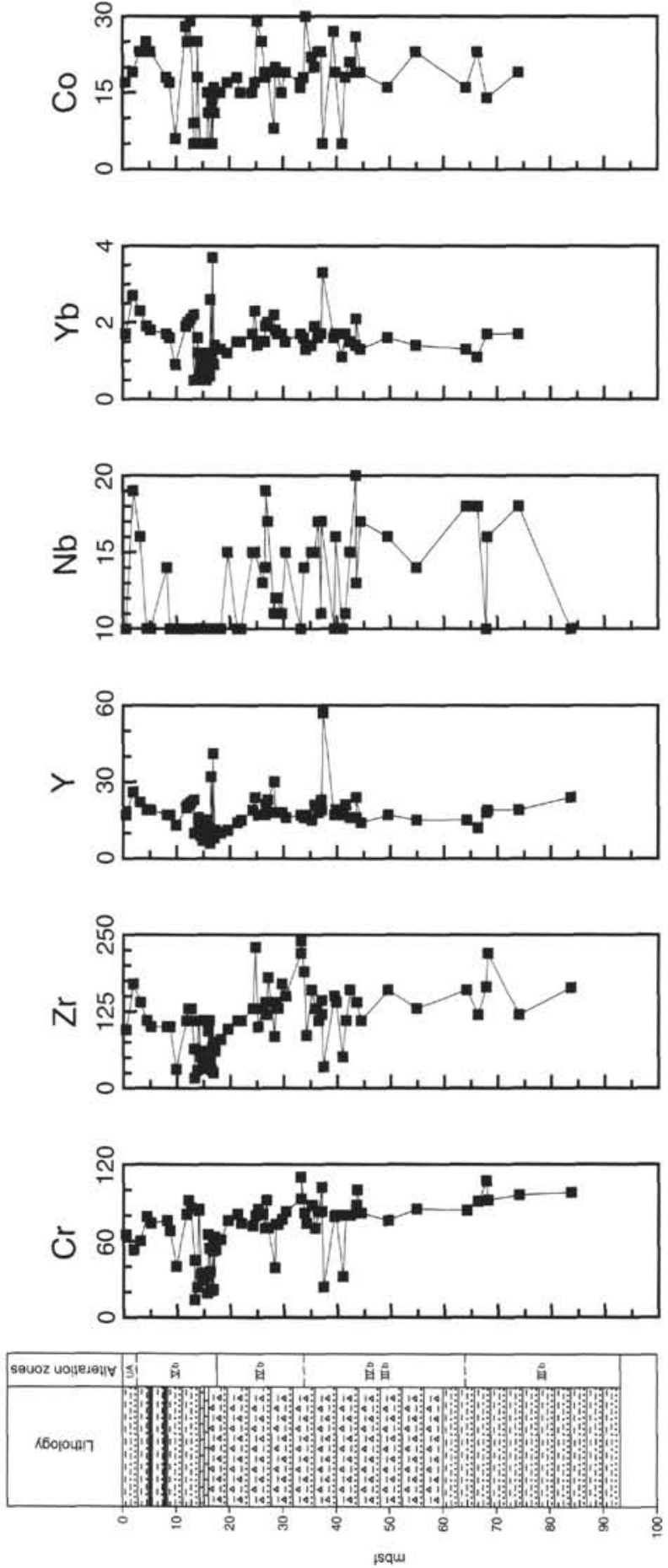

compositions (Butterfield et al., this volume) indicate a common source and origin, and on this basis a transition from high-temperature, metal-rich fluids to lower-temperature, metal-poor fluids at $\mathrm{BH}$ also occurred more than 2000 years ago.

\section{Hydrothermal Reaction Zone}

Hydrothermally altered sediments at Site 857 are zoned upward from a quartz-epidote \pm wairakite \pm chlorite assemblage (Zones Ic and IIc below $450 \mathrm{mbsf}$ ) to albite - chlorite - pyrite (Zone IIIc) and calcite - illite -pyrite (Zone IVc). This zonation corresponds to a fairly uniform increase of temperature downhole, reaching a maximum of $300^{\circ} \mathrm{C}$ at about 450 mbsf (Baker et al., this volume; W.D. Goodfellow, unpubl. data). Between 450 and 695 mbsf in Hole 857D, fluid inclusion temperatures for wairakite range between $242^{\circ}$ and $350^{\circ} \mathrm{C}$ and do not show any systematic downhole variation (Peter et al., this volume). This, combined with the stratabound nature of Zone Ic and its pervasive alteration, suggests that this reaction zone behaved essentially isothermally during most of its history and is therefore a reservoir for hydrothermal fluids that are presently venting at the AAV. This interpretation is consistent with the conclusion that temperature conditions in the sediment-sill complex below about $470 \mathrm{mbsf}$ are isothermal, based on downhole temperature measurements and physical properties (Davis and Wang, this volume). The extensive reaction between hydrothermal fluid and sediments is shown by $\delta^{18} \mathrm{O}_{\text {SMow }}$ values as low as $5.48 \%$ for altered sediment from Zone Ic (compared to values between 10.9 and $11.7 \%$ for bulk sediments; Goodfellow et al., 1993), a primitive ${ }^{87} \mathrm{Sr}{ }^{86} \mathrm{Sr}$ ratio of 0.704307 in Zone Ic (W.D. Goodfellow, unpubl. data), and replacement of all sedimentary silicates with the exception of detrital quartz by quartz and epidote. The replacement of $\mathrm{K}$-Al-silicates by $\mathrm{Ca}-\mathrm{Al}$-silicates and albite is reflected by a marked decrease in elements that occur in $\mathrm{K}$-feldspar and mica $\left(\mathrm{K}_{2} \mathrm{O}, \mathrm{Rb}\right.$, and $\mathrm{Ba}$ ), and an increase in $\mathrm{CaO}, \mathrm{Na}_{2} \mathrm{O}$, and $\mathrm{Sr}$ contents (Fig. 23). Samples from Zone Ic (Fig. 27) overlap the compositional field for samples from the AAV upflow zone (Zone Ib) (Fig. 25). The alteration of sedimentary minerals in this zone is recorded by major decreases of $\mathrm{Zn}, \mathrm{Cu}, \mathrm{Be}, \mathrm{As}, \mathrm{Sb}$, and Se relative to unaltered sediment (Table 3). Lead is also probably leached from this zone although the extent of $\mathrm{Pb}$ loss cannot be determined because of the high detection limits ( 20 $\mathrm{ppm}$ ) of the analytical methods used.

The upward zonation of hydrothermal minerals at Site 857 is similar to the distribution of minerals about the Site 858 upflow zone, suggesting that the processes of hydrothermal alteration are similar in both areas. In the case of the AAV (Site 858), hydrothermal fluids have clearly migrated outward, mixed with connate fluids and entrained seawater, and reacted with hemipelagic and turbiditic sediments under decreasing temperature conditions. At Site 857, hydrothermal fluids have also migrated upward from the reaction zone and reacted with sediments, producing the mineral zonation observed in Holes $857 \mathrm{C}$ and 857D. The addition of elements (e.g., $\mathrm{Na}, \mathrm{Fe}, \mathrm{Mg}$ ) in Zone IIIc and ${ }^{87} \mathrm{Sr} /{ }^{86} \mathrm{Sr}$ ratios that increase upward from 0.704307 in Zone Ic to 0.70650 in Zone IIIc (W.D. Goodfellow, unpubl. data) indicates major upward advection of fluids from the hydrothermal reservoir (Zones Ic and IIc).

Several indicators suggest that hydrothermal fluids venting at AAV originate from a hydrothermal reaction zone similar to that at Site 857: (1) the mineral assemblages (Leybourne and Goodfellow, this volume) and bulk chemistry of the reaction Zone Ic at Site 857 and Zone Ib near the center of fluid upflow at the AAV are similar and therefore have formed from fluids of similar composition; (2) the $\mathrm{Sr}$ isotope composition of altered sediments from Zone Ic $\left({ }^{87} \mathrm{Sr} /{ }^{86} \mathrm{Sr}=\right.$ 0.704307, Sample 857D-11R-1, 1-3 cm; W.D. Goodfellow, unpubl. data) is nearly identical to an average ${ }^{87} \mathrm{Sr} /{ }^{86} \mathrm{Sr}$ value of 0.70424 in vent fluids from the AAV (Butterfield et al., this volume); (3) high trapping temperatures measured for fluid inclusions in quartz and wairakite from Zones Ib (AAV) and Ic (Site 857) fall within the same 

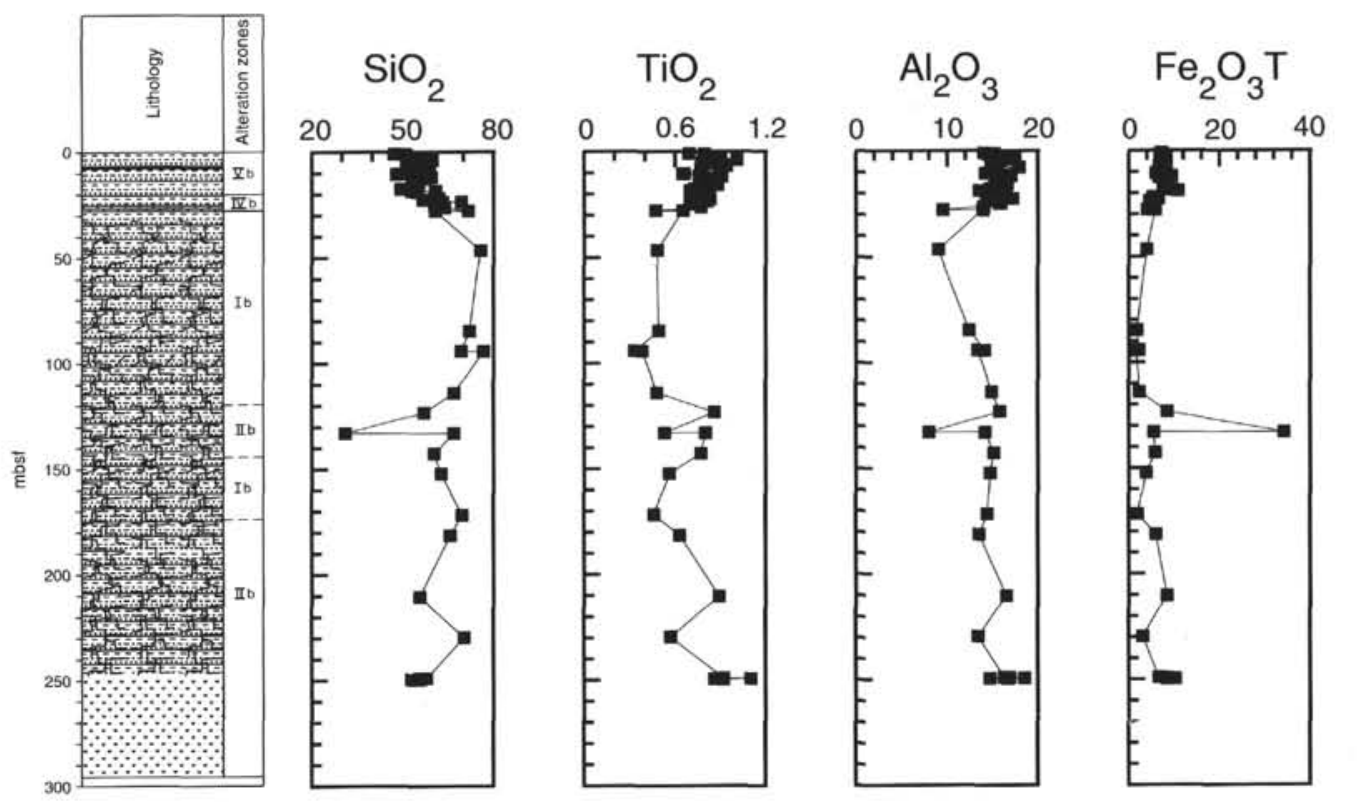

$\mathrm{MnO}$
$0 \quad 0.1 \quad 0.2$

$\begin{array}{r}\mathrm{Na}_{2} \mathrm{O} \\ \quad \quad 2.5 \\ \hline\end{array}$
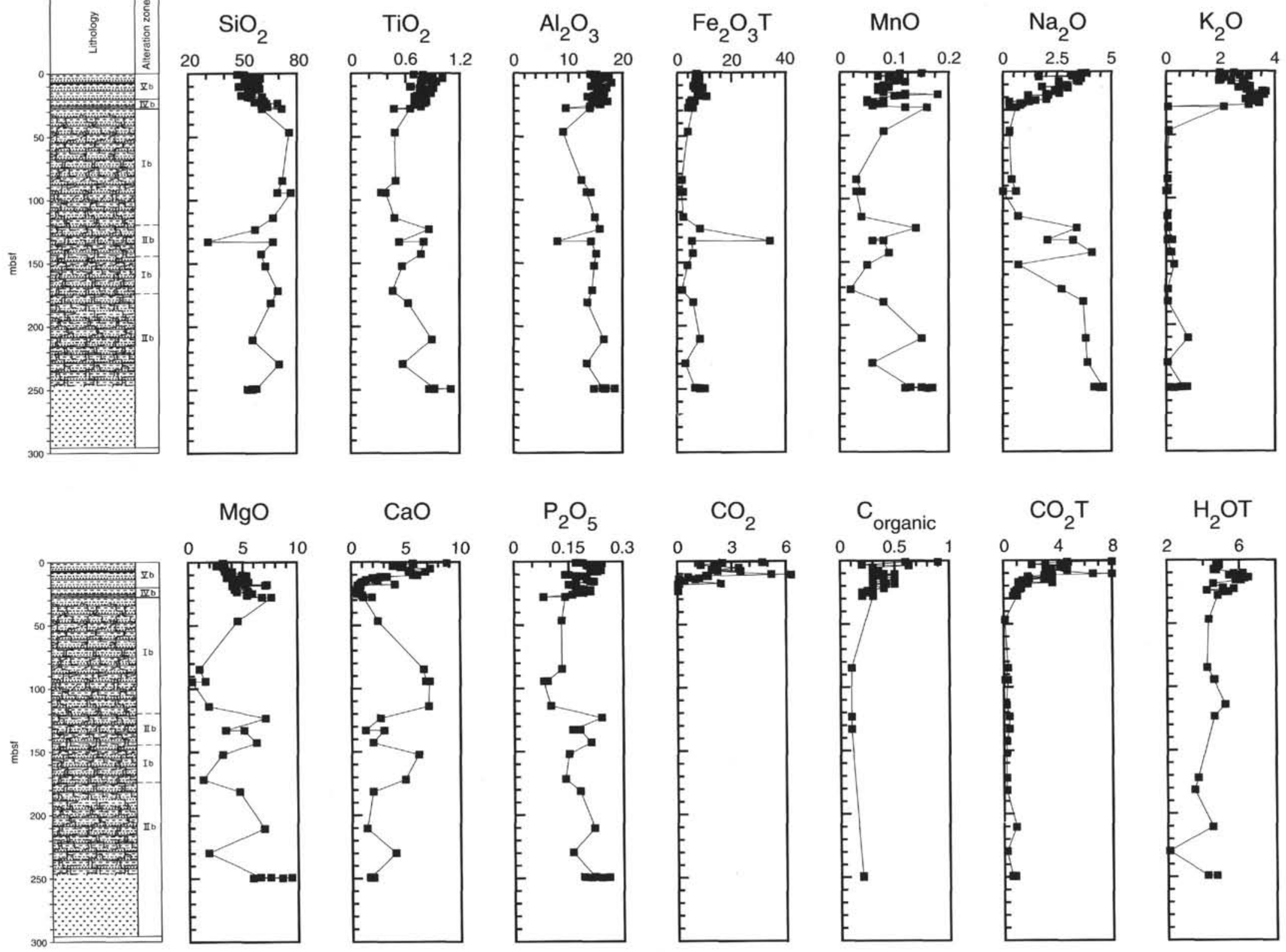

$\mathrm{C}_{\text {organic }} \quad \mathrm{CO}_{2}^{\top}$

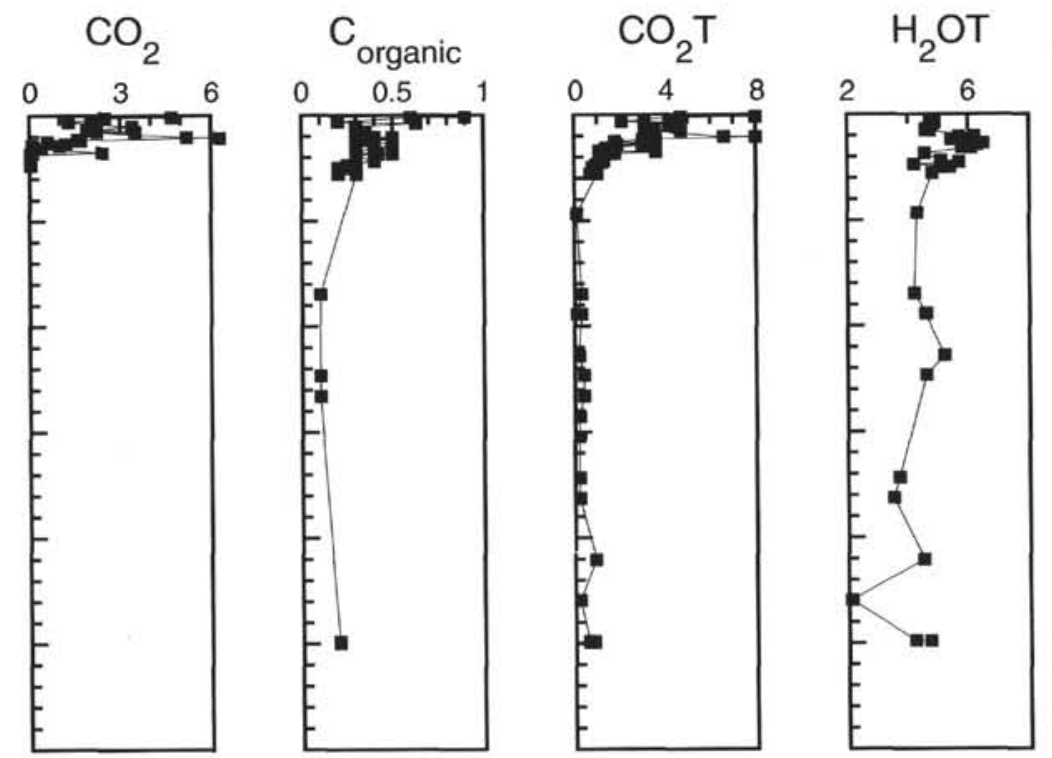

Figure 22A. Downhole profiles of major element bulk compositions for altered and unaltered hemipelagic and turbiditic sediments, Holes $858 \mathrm{D}$ and $858 \mathrm{~F}$.

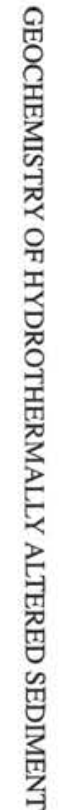



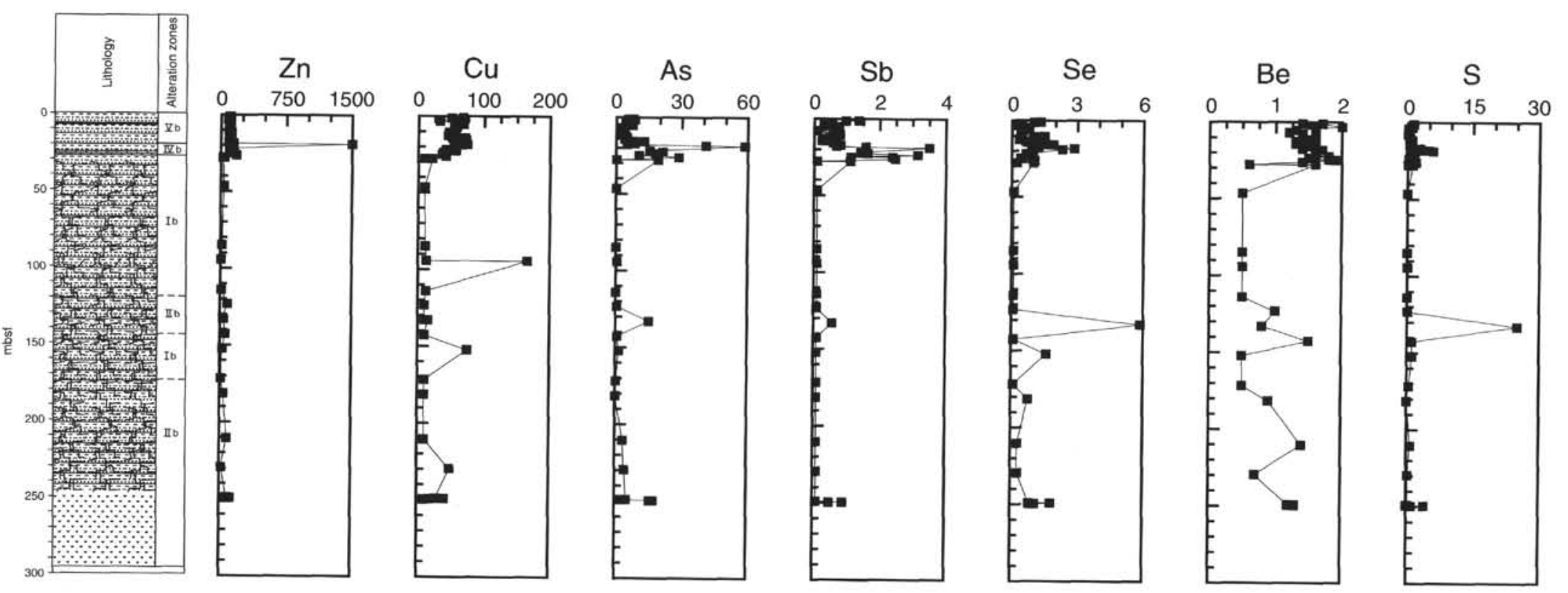

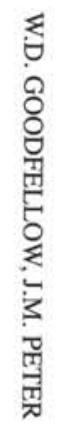
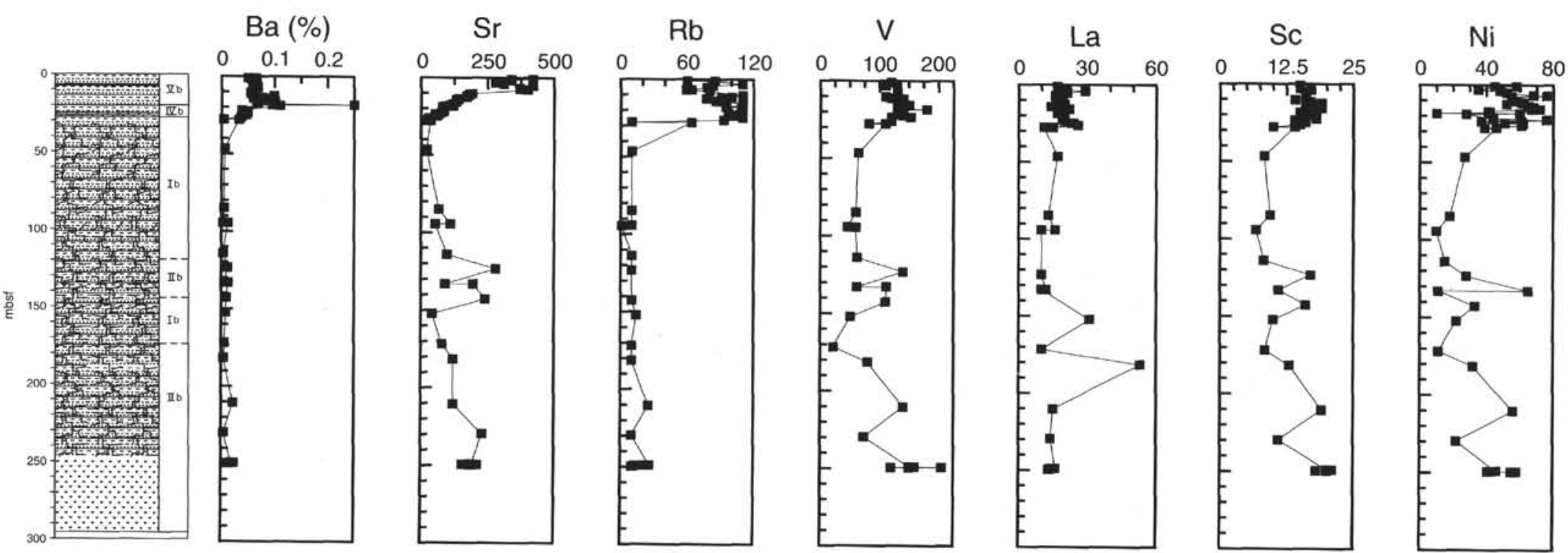

Figure 22B. Downhole profiles of minor and trace element bulk compositions for altered and unaltered hemipelagic and turbiditic sediments, Holes 858D and 858F. 

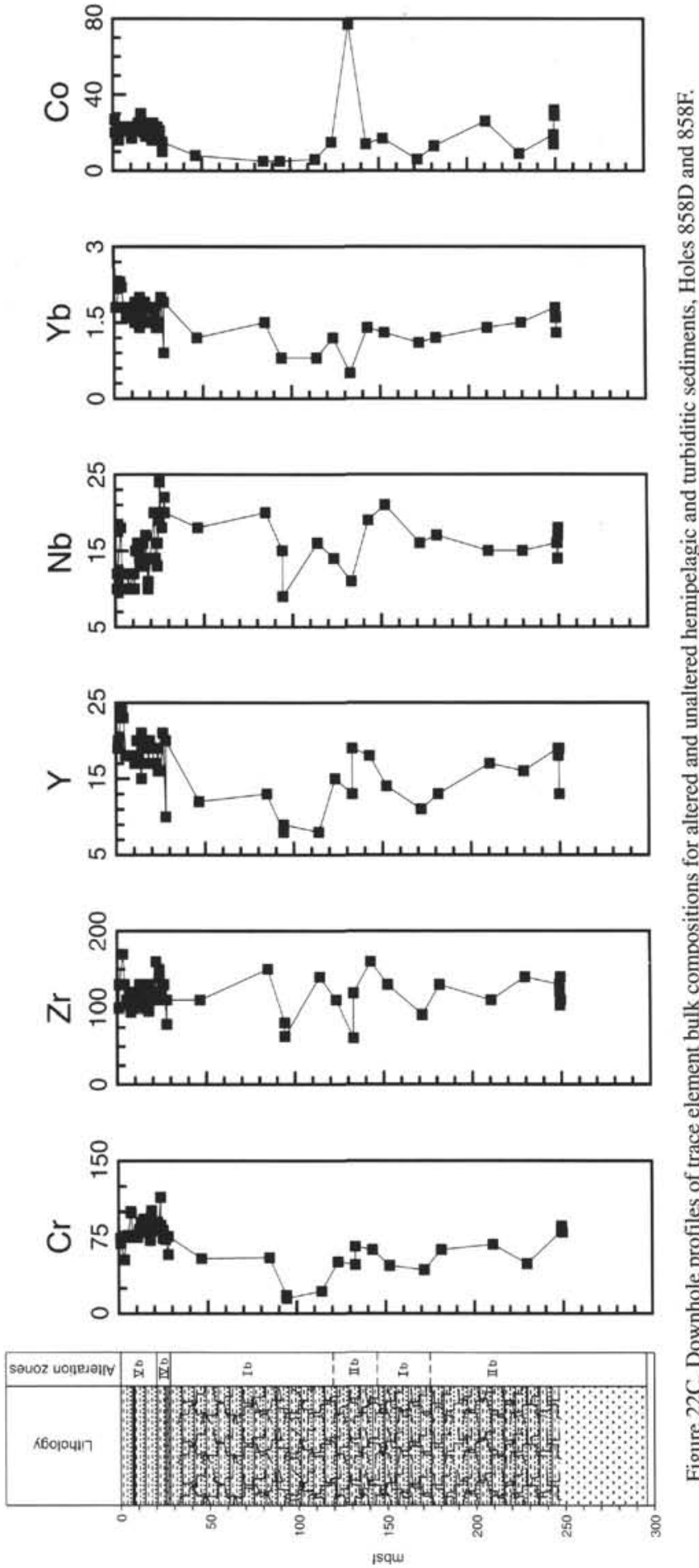

range $\left(242^{\circ}\right.$ to $350^{\circ} \mathrm{C}$; Peter et al., this volume) as do temperatures for vent fluids ( $184^{\circ}$ to $274^{\circ} \mathrm{C}$; Goodfellow and Franklin, 1993); and (4) the similarity of $\mathrm{Na}, \mathrm{Ca}$, and $\mathrm{Cl}$ contents of inclusion (Peter et al., this volume) and AAV vent fluids (Lydon et al., 1991; Butterfield et al., this volume) at AAV. Therefore, the wairakite-epidote-quartz assemblage in both the upflow (Zone $\mathrm{Ib}$ ) at AAV and underlying reaction (Zone Ic; Site 857) zones equilibrated with hydrothermal fluids similar to those at AAV. $\log a \mathrm{Ca}^{2+} / a 2 \mathrm{H}^{+}$ratios for vent fluids from AAV straddle the wairakite-clinozoisite stability boundary but are displaced to higher silica activities because of its supersaturation with respect to quartz (Fig. 26). The dominance of Ca-bearing phases in Zone Ic (Site 857) is consistent with the high $\mathrm{aCa}^{2+} / \mathrm{aNa}^{+}$ratios in vent fluids from the AAV (Lydon et al., 1992; Butterfield et al., this volume). Possible sources of $\mathrm{Ca}$ include (1) biogenic carbonate, (2) calcic plagioclase dissolved and albitized, respectively, by downwelling seawater; and (3) anhydrite that may have been deposited in sediments below 450 mbsf during an earlier stage in the hydrothermal system and has now been dissolved.

The former presence of anhydrite in sediments that have reacted with $300^{\circ} \mathrm{C}$ fluids may have generated the highly positive $\mathrm{S}$ isotope values (mean $=8.1 \%$ ) for the high-temperature pyrrhotite-wurtziteisocubanite in the $\mathrm{BH}$ massive sulfide deposit, which requires a major component of seawater sulfate (Goodfellow and Franklin, 1993). Although inorganic reduction of sulfate by reaction of hydrothermal fluids with seawater in sulfide chimneys and mounds may have occurred, the reduction potential is not sufficient to generate $\delta^{34 \mathrm{~S}\left(\mathrm{H}_{2} \mathrm{~S}\right)}$ values above about $4.5 \%$ (Janecky and Shanks et al., 1988). The reaction of hydrothermal fluids with seawater sulfate from subsurface mixing or previously deposited anhydrite can, however, produce $\left.\delta^{34 \mathrm{~S}(\mathrm{H}}{ }_{2} \mathrm{~S}\right)$ values that exceed $5 \%$.

Most of the elements leached from Zone Ic at Site 857 are concentrated in hydrothermal anhydrite-sulfide chimneys, sedimentary sulfides, and alteration zones at the AAV (Goodfellow et al., 1993). For example, sulfidic sediments in shallow cores from the AAV contain up to $2.5 \mathrm{wt} \% \mathrm{Cu}, 0.96 \mathrm{wt} \% \mathrm{Zn}, 0.38 \mathrm{wt} \% \mathrm{~Pb}, 1.9 \mathrm{wt} \% \mathrm{Ba}, 26 \mathrm{ppm}$ As, 272 ppm Se, 14 ppm Sb, and 2.1 ppm Be (Turner et al., 1993). These elements are also concentrated in the sulfide unit in Hole 858B (Fig. 20) and in the outer alteration zones at Site 858 (Zones IIb to $\mathrm{Vb}$ ). The similarity of the suite of elements which exhibits mass losses from Zone Ic (Site 857) and those concentrated in seafloor hydrothermal products at the AAV suggests that most of the metals, $\mathrm{Ba}$, and $\mathrm{Sr}$ were leached from highly altered sediments intercalated with mafic sills below about $450 \mathrm{mbsf}$ at Site 857 . If the reaction zone underlying Middle Valley is at least $0.5 \mathrm{~km}$ thick, $10 \mathrm{~km}$ wide and $40 \mathrm{~km}$ long, the total mass loss from this zone, calculated on the basis of elements removed from Zone Ic, is 20 million tons of $\mathrm{Zn}, 8$ million tons of $\mathrm{Cu}$, and 220 million tons of $\mathrm{Ba}$. Since the sulfide mass present at the AAV is far less than this amount of metals, estimates of the size of the reaction zone are either too large or most of the metals have been lost to the water column as occurs at $21^{\circ} \mathrm{N}$, EPR (Converse et al., 1984).

\section{SUMMARY AND CONCLUSIONS}

1. Two distinct hydrothermal upflow zones were penetrated during drilling in Middle Valley: BH (Site 856) and the AAV (Site 858). The general distribution of the hydrothermal fluid upflow and reaction zones, associated hydrothermal alteration, seafloor depositional products, and the fluid flow regime are shown on a schematic block diagram of the Middle Valley sedimented rift in Figure 28.

2 . The $\mathrm{BH}$ upflow zone is a fossil hydrothermal fluid discharge conduit associated with a major sulfide deposit near the southern flanks of a sediment mound. This upflow zone is texturally, mineralogically, and chemically zoned from a highly indurated, fractured, and veined inner core consisting of quartz + muscovite + chlorite + rutile + sulfides to weakly altered sediments on the margins of the fluid conduit. The inner core is characterized by mass gains of $\mathrm{Si}, \mathrm{Fe}$, 

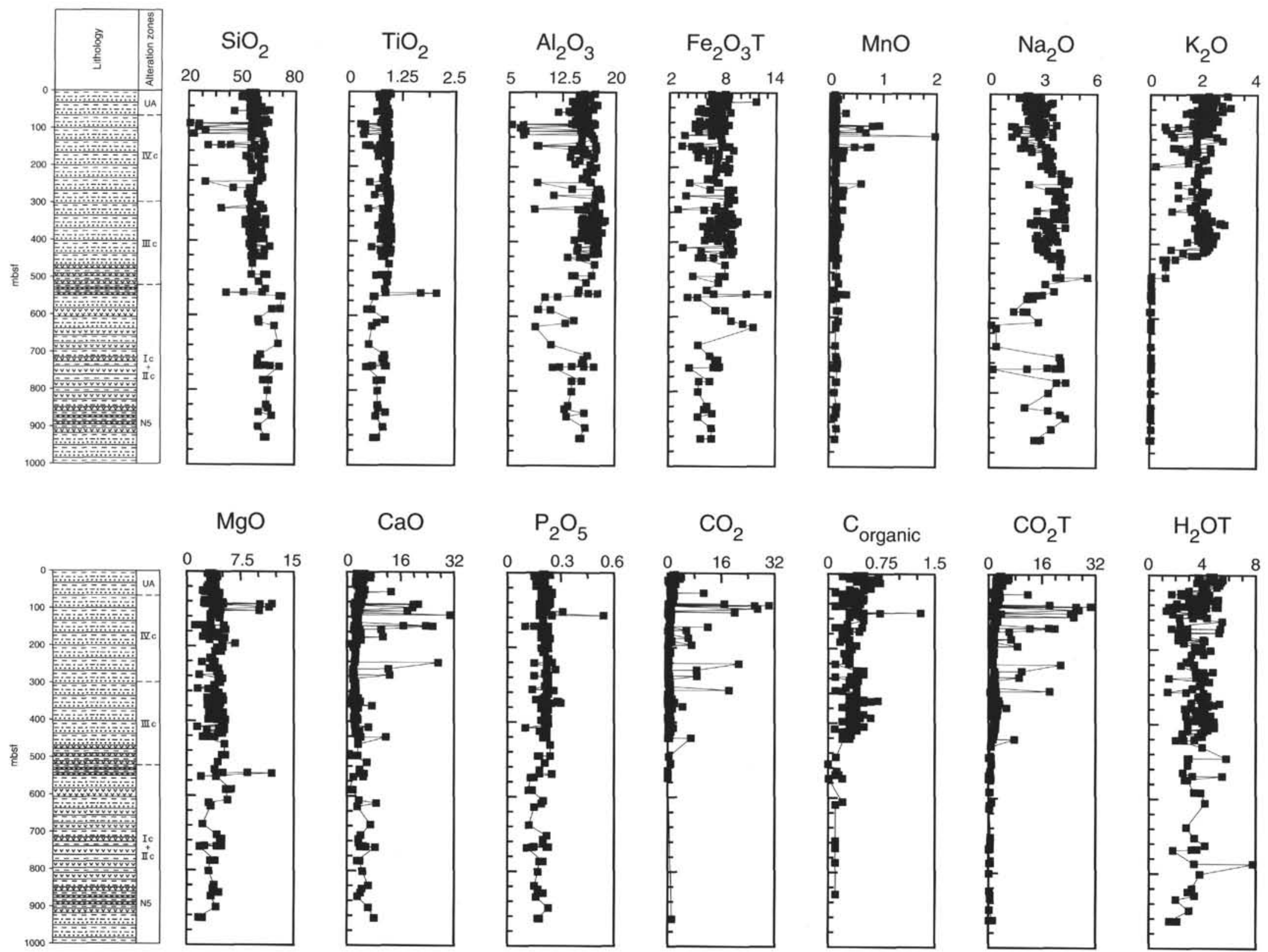

Figure 23A. Downhole profiles of major element bulk compositions for altered and unaltered hemipelagic and turbiditic sediments, Holes 857A, 857C and 857D. 

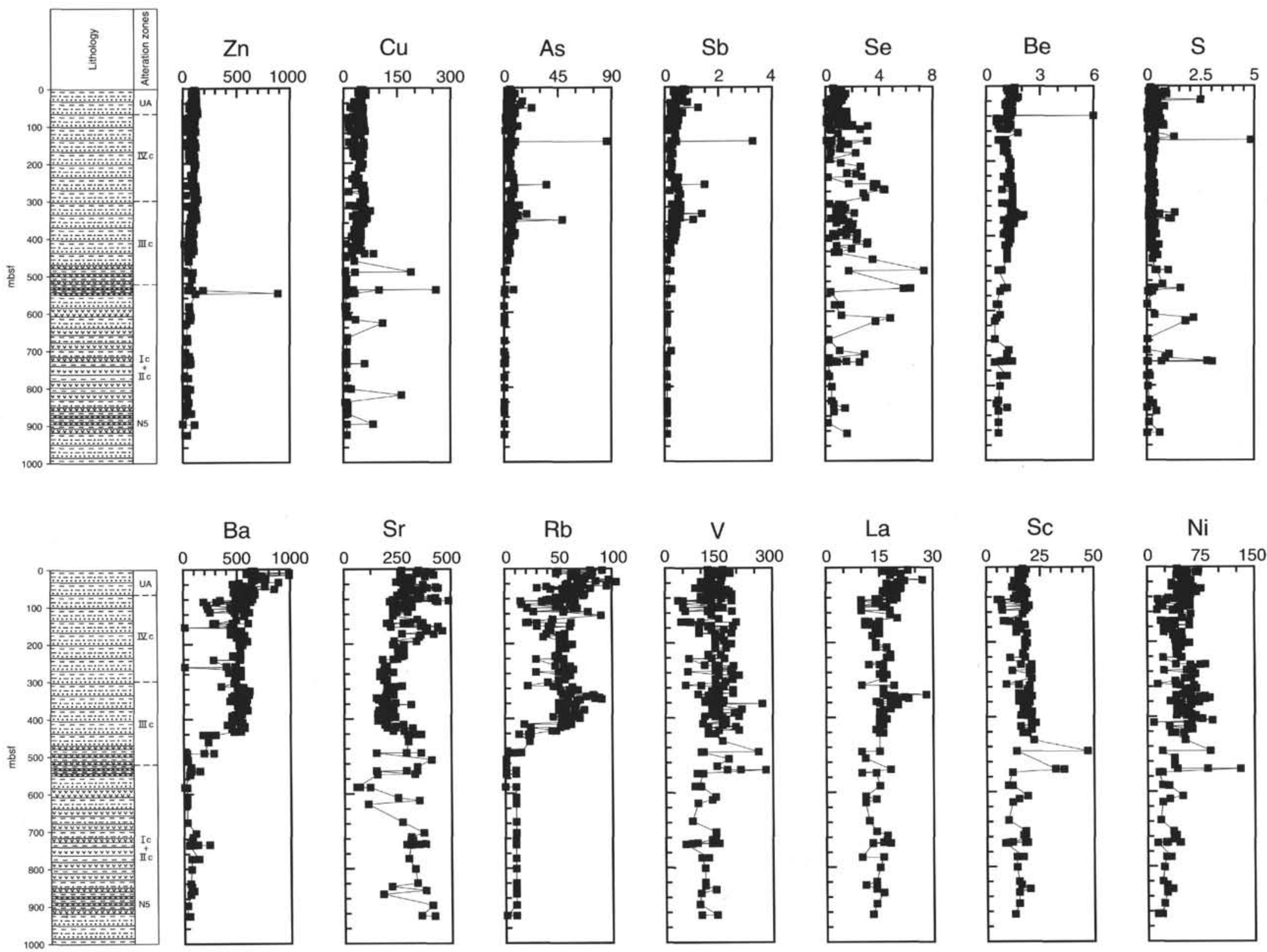

Figure 23B. Downhole profiles of minor and trace element bulk compositions for altered and unaltered hemipelagic and turbiditic sediments, Holes 857A, 857C and 857D. 

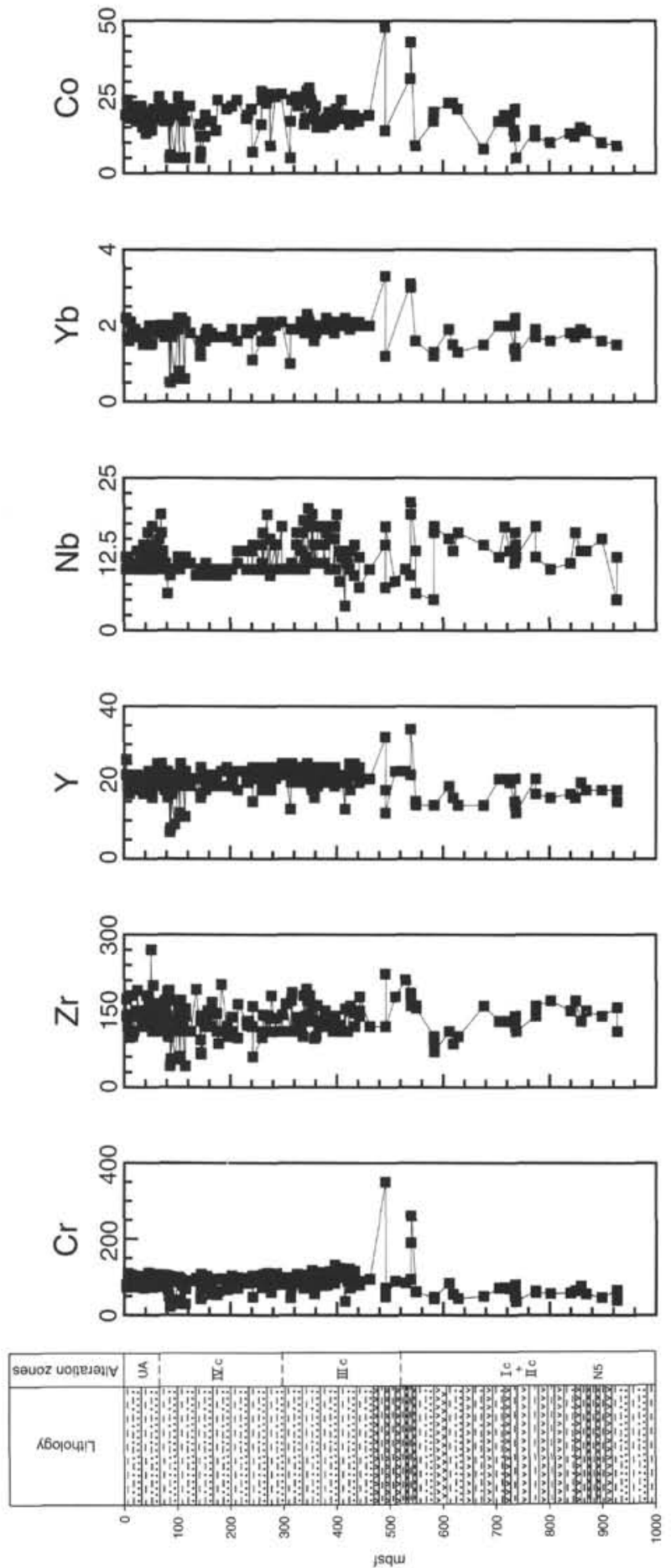

$\mathrm{AI}, \mathrm{Mg}, \mathrm{S}, \mathrm{K}, \mathrm{Mn}, \mathrm{Cu}, \mathrm{Ba}, \mathrm{Zn}, \mathrm{Se}, \mathrm{Co}$, and $\mathrm{Cr}$, and mass losses of $\mathrm{Ca}$, $\mathrm{Na}, \mathrm{CO}_{2}$, TOC, As, and $\mathrm{Sc}$. In the surrounding alteration zones, $\mathrm{Mg}$ and $\mathrm{Fe}$ have been added at the expense of alkali elements bound in detrital feldspar and micas. Pyrrhotite-chalcopyrite veins associated with quartz that precipitated at temperatures up to $338^{\circ} \mathrm{C}$ in the core of this upflow zone indicate that the $\mathrm{BH}$ sulfide deposit formed from a high-temperature metalliferous fluid.

3 . The AAV upflow zone is associated with anhydrite-sulfide chimneys that are actively discharging $184^{\circ}$ to $276^{\circ} \mathrm{C}$ fluids (Goodfellow and Franklin, 1993). This fluid conduit is zoned from a lithified, fractured, brecciated, veined, and high-temperature $\left(250^{\circ}-316^{\circ} \mathrm{C}\right)$ inner core composed of quartz-wairakite-epidote to weakly altered sediments on the margins of the upflow zone. The major elements added to the core of the conduit are $\mathrm{Ca}, \mathrm{Si}, \mathrm{Al}$, and $\mathrm{H}$; elements removed include $\mathrm{Fe}, \mathrm{Na}, \mathrm{K}, \mathrm{CO}_{2}$, TOC, $\mathrm{Ba}, \mathrm{Sr}, \mathrm{Rb}, \mathrm{Zn}, \mathrm{As}, \mathrm{Cu}, \mathrm{Ni}$, and V.

4. Although the $\mathrm{BH}$ and $\mathrm{AAV}$ upflow zones are similar in size and morphology, the inner cores are mineralogically and geochemically distinct and have formed by reaction with hydrothermal fluids of different temperature and composition. The venting of metal-poor, moderate temperature $\left(<300^{\circ} \mathrm{C}\right)$ fluids at the $\mathrm{AAV}$ and $330 \mathrm{~m}$ south of $\mathrm{BH}$ (Goodfellow and Franklin, 1993), and fluid inclusion temperatures of $200^{\circ}-300^{\circ} \mathrm{C}$ quartz interstitial to massive sulfides (Peter et al., this volume), indicate that the temperature, metal-content, and possibly source of hydrothermal fluids in Middle Valley have changed with time.

5. The textural, mineralogical, and chemical zonation about the $\mathrm{AAV}$ and $\mathrm{BH}$ upflow zones is consistent with precipitation from upflowing and outflowing hydrothermal fluid that mixed with downdrawn, heated seawater on the margins of the discharge conduit. The inner core assemblages are products of reaction between sediments and end-member hydrothermal fluid, whereas the surrounding alteration zones formed by the reaction of sediments with chemically evolved hydrothermal fluids and heated entrained seawater.

6. The local hydrology within zones of fluid upflow is probably complex due to the low cross-stratal permeability of unaltered sediments, the highly variable permeabilities from the core to the margins of the conduit, and temporal variability in permeability due to the filling of fractures by hydrothermal minerals. During periods of unrestricted fluid discharge in the central conduit, seawater was probably entrained into the discharge conduit, resulting in the dumping of $\mathrm{Mg}$ in the form of Mg-rich silicates. Clogging of the conduit by mineral precipitation may have forced fluids laterally along permeable turbidites, producing the widespread alteration that surrounds the inner core. Because such sealing and breaching of the upflow zone most likely occurred episodically, the direction of lateral flow probably alternated from outward-flowing to inward-flowing fluids. This change in hydrologic regime may account for the overprinting of Mg-rich minerals by high-temperature phases, and the formation of lower-temperature minerals in fractures (e.g., anhydrite, calcite) that crosscut the high-temperature, lithified core.

7. The mineralogical similarities between hydrothermally altered sediment in the core of the AAV upflow zone and the Site 857 sediment-sill complex indicate that vent fluids at AAV probably originated in a hydrothermal reaction zone at the base of the Middle Valley sedimentary sequence. This conclusion is supported by $\mathrm{Sr}$ and $\mathrm{Pb}$ isotope results (Goodfellow and Franklin, 1993) that clearly indicate mixed sedimentary and basaltic sources for hydrothermal carbonates and sulfides.

8. The Middle Valley hydrothermal system is complex and has evolved with time; it consisted of (1) a reaction zone, probably associated with a high-level magma body near the rift axis, where hightemperature, metal-rich "black smoker"-type fluids were generated, and (2) a secondary reaction zone in the sill complex near the base of the sedimentary pile where these fluids acquired isotopically heavy $\mathrm{S}$ by reaction with sediments (possibly containing anhydrite). It was this modified high-temperature system that generated the large, hydrothermally inactive $\mathrm{BH}$ massive sulfide deposit at Site 856 . The 


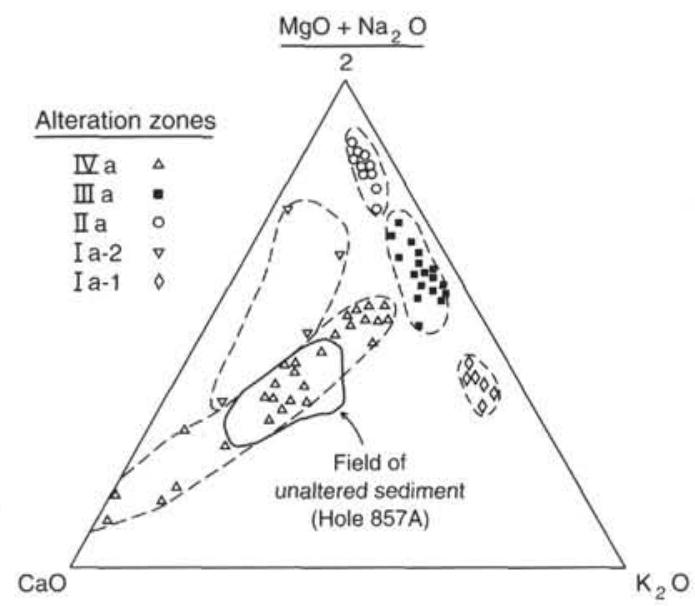

Figure 24. Ternary $\left(\mathrm{MgO}+\mathrm{Na}_{2} \mathrm{O}\right)-\mathrm{K}_{2} \mathrm{O}-\mathrm{CaO}$ plot showing the chemical changes between the alteration zones at $\mathrm{BH}(\mathrm{Site} 856) . \mathrm{Zone} \mathrm{Ia}=$ quartz + $(\mathrm{Fe})$ chlorite + muscovite + rutile + sulfides; $\mathrm{Ia}=$ quartz + chlorite + pyrite; $\mathrm{IIIa}=$ anhydrite + clay + pyrite + barite $; \mathrm{IVa}=$ calcite + clay + pyrite.

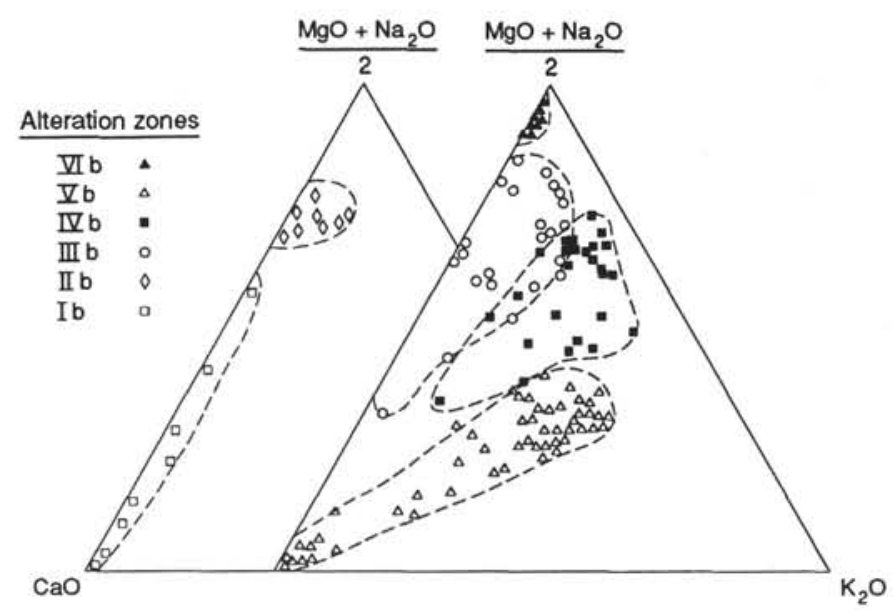

Figure 25. Ternary $\left(\mathrm{MgO}+\mathrm{Na}_{2} \mathrm{O}\right)-\mathrm{K}_{2} \mathrm{O}-\mathrm{CaO}$ plot showing the chemical changes between alteration zones at the AAV (Site 858). Zone $\mathrm{Ib}=$ wairakite + epidote + quartz; IIb $=$ quartz + chlorite + epidote + pyrite; IIIb = albite + chlorite + pyrite $; \mathrm{IVb}=$ anhydrite + illite + pyrite $; \mathrm{Vb}=$ calcite + clay + pyrite \pm barite; $\mathrm{VIb}=$ saponite + pyrite .

present hydrothermal system at the AAV and south of $\mathrm{BH}$ is lower temperature and appears to be contained within the sediment-sill complex below about $450 \mathrm{mbsf}$. Hydrothermal fluids from this active system are generally $<300^{\circ} \mathrm{C}$ and metal-poor. Hydrothermal precipitates consist of anhydrite-sulfide chimneys with higher $\mathrm{Cu} / \mathrm{Zn}$ ratios than in the hydrothermally inactive BH sulfide deposit (Goodfellow and Franklin, 1993).

\section{ACKNOWLEDGMENTS}

We thank Conrad Gregoire for supervising the chemical analyses of sulfide and sediment samples, Jennifer Shaw for maintaining the chemical database, and Martina Wecke and Matthew Leybourne for preparing diagrams and plotting data, respectively. Discussions with Matthew Leybourne were useful in formulating some of our ideas about the Middle Valley hydrothermal system. This paper has also benefitted from the careful reviews of Tim Barrett, David Lentz, Matthew Leybourne and Mike Mottl, and the editorial comments of N. McQuistion of ODP.

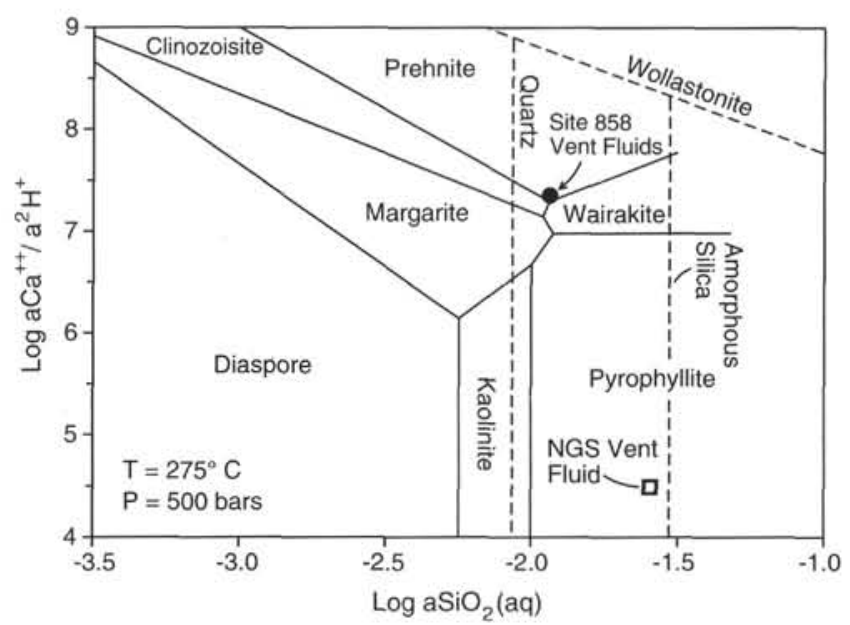

Figure 26. $\log a \mathrm{SiO}_{2}$ vs. $\log a \mathrm{Ca}^{2+} / a^{2} \mathrm{H}^{+}$phase diagram for the system $\mathrm{CaO}$ - $\mathrm{Al}_{2} \mathrm{O}_{3}-\mathrm{SiO}_{2}-\mathrm{H}_{2} \mathrm{O}$ at $275^{\circ} \mathrm{C}$. End-member hydrothermal fluids from AAV have $\log a \mathrm{Ca}^{2+} / \mathrm{a}^{2} \mathrm{H}^{+}$ratios (Butterfield et al., this volume) that straddle the wairakite-clinozosite equal activity boundary but are displaced to the right due to high $a \mathrm{SiO}_{2}$ (aqueous) values. The supersaturation of silica reflects the sluggish kinetics of quartz crystallization.

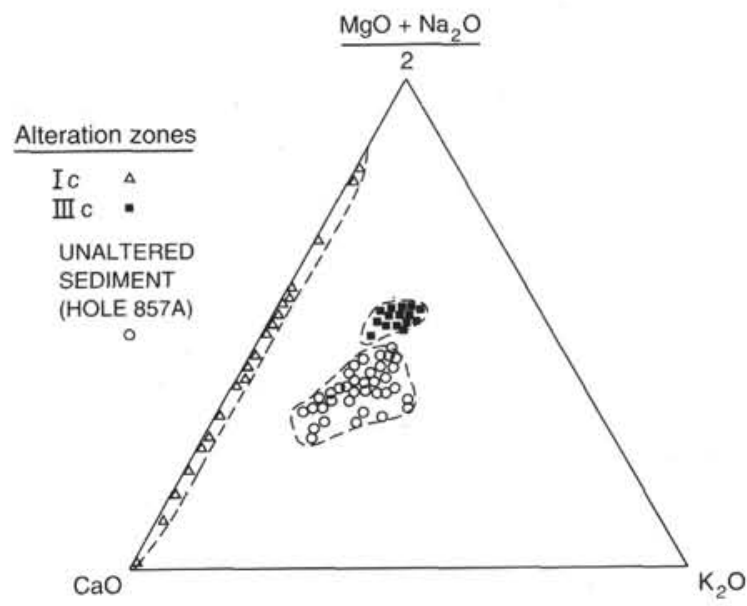

Figure 27. Ternary $\left(\mathrm{MgO}+\mathrm{Na}_{2} \mathrm{O}\right)-\mathrm{K}_{2} \mathrm{O}-\mathrm{CaO}$ plot showing the chemical changes between alteration zones and unaltered hemipelagic and turbiditic sediment at Site 857. Zone Ic $=$ wairakite + epidote + quartz; Zone IIIc $=$ albite + chlorite + pyrite.

\section{REFERENCES*}

Berman, R.G., 1988. Internally-consistent thermodynamic data for minerals in the system $\mathrm{Na}_{2} \mathrm{O}-\mathrm{K}_{2} \mathrm{O}-\mathrm{CaO}-\mathrm{MgO}-\mathrm{FeO}-\mathrm{Fe}_{2} \mathrm{O}_{3}-\mathrm{Al}_{2} \mathrm{O}_{3}-\mathrm{SiO}_{2}-\mathrm{TiO}_{2}-\mathrm{H}_{2} \mathrm{O}$ $\mathrm{CO}_{2}$. J. Petrol., 292:445-522.

Berner, R.A., 1984. Sedimentary pyrite formation: an update. Geochim. Cosmochim. Acta, 48:605-615.

Blount, C.N., and Dickson, F.W., 1969. The solubility of anhydrite $\left(\mathrm{CaSO}_{4}\right)$ in $\mathrm{NaCl}-\mathrm{H}_{2} \mathrm{O}$ from 100 to $450^{\circ} \mathrm{C}$ and 1 to 100 bars. Geochim. Cosmochim. Acta, 33:227-245.

Bowers, T.S., Campbell, A.C., Measures, C.I., Spivack, A.J., Khadem, M., and Edmond, J.M., 1988. Chemical controls on the composition of vent fluids

\footnotetext{
Abbreviations for names of organizations and publications in ODP reference lists follow the style given in Chemical Abstracts Service Source Index (published by American Chemical Society).
} 
at $13^{\circ} \mathrm{N}-11^{\circ} \mathrm{N}$ and $21^{\circ} \mathrm{N}$, East Pacific Rise. J. Geophys. Res., 93:45224536.

Bowers, T.S., Von Damm, K.L., and Edmond, J.M., 1985. Chemical evolution of mid-ocean ridge hot springs. Geochim. Cosmochim. Acta, 49:2239-2252.

Brown, T.H., Berman, R.G., and Perkins, E.H., 1988a. GEO-CALC: software package for rapid calculation and display of pressure-temperature-composition phase diagrams using an IBM or compatible personal computer. Comp. Geosci., 14:279-290.

, 1988b. GEO-CALC: II. PTA-system. Software for calculation and display of pressure-temperature-activity phase diagrams. Univ. of British Columbia, Vancouver, B.C., Canada.

Campbell, A.C., Bowers, T.S., and Edmond, J.M., 1988. A time-series of vent compositions from $21^{\circ} \mathrm{N}$ EPR $(1979,1981,1985)$ and the Guaymas Basin, Gulf of California. J. Geophys. Res., 93:4537-4551.

Chamley, H., 1971. Recherches sur la sedimentation argileuse en Méditerranée. Sci. Geol. Mem., 35.

Converse, D.R., Holland, H.D., and Edmond, J.M., 1984. Flow rates in the axial hot springs of the East Pacific Rise $\left(21^{\circ} \mathrm{N}\right)$ : implications for the heat budget and the formation of massive sulfide deposits. Earth Planet. Sci. Lett., 69:159-175.

Crerar, D.A., and Barnes, H.L., 1976. Ore solution chemistry V. Solubilities of chalcopyrite and chalcocite assemblages in hydrothermal solution at $200^{\circ} \mathrm{C}$ to $350^{\circ} \mathrm{C}$. Econ. Geol., 71:772-794.

Davis, E.E., Goodfellow, W.D., Bornhold, B.D., Adshead, J., Blaise, B., Villinger, H., and Le Cheminant, G.M., 1987. Massive sulfides in a sedimented rift valley, northern Juan de Fuca Ridge. Earth Planet. Sci. Lett., 82:49-61.

Davis, E.E., Mottl, M.J., Fisher, A.T., et al., 1992. Proc. ODP, Init. Repts., 139: College Station, TX (Ocean Drilling Program).

Davis, E.E., and Sawyer, B., 1987. Marine geophysical maps of western Canada. Geol. Surv. Can. Bathymetric Map 6-1987.

Davis, E.E., and Villinger, H., 1992. Tectonic and thermal structure of the Middle Valley sedimented rift, northern Juan de Fuca Ridge. In Davis, E.E., Mottl, M.J., Fisher, A.T., et al., Proc. ODP, Init. Repts., 139: College Station, TX (Ocean Drilling Program), 9-41.

Ding, K., and Seyfried, W.E., Jr., 1989. $\mathrm{H}_{2}$ and $\mathrm{H}_{2} \mathrm{~S}$ concentrations as indicators of temperature in ridge crest hydrothermal systems. Eos, 71:1680.

Edmond, J.M., Measures, C., McDuff, R.E., Chan, L.H., Collier, R., and Grant, B., 1979. Ridge crest hydrothermal activity and the balances of the major and minor elements in the ocean: the Galapagos data. Earth Planet. Sci. Lett., 46:1-19.

Edmond, J.M., and Von Damm, K.L., 1985. Chemistry of ridge crest hot springs. Biol. Soc. Wash. Bull., 6:43-47.

Floyd, P.A., and Winchester, J.A., 1978. Identification and discrimination of altered and metamorphosed volcanic rocks using immobile elements. Chem. Geol., 21:291-306.

Francheteau, J., Juteau, T., and Rangan, C., 1979. Basaltic pillars in collapsed lava-pools on the deep-ocean floor. Nature, 281:209-211.

Franklin, J.M., and Leg 139 Scientific Party, 1992. Formation of massive sulphide deposits in Middle Valley, northern Juan de Fuca Ridge. Geol. Surv. Can. Minerals Colloq., Ottawa, Abstr. with Progr., 20. (Abstract)

Goldfarb, M.S., Converse, D.R., Holland, H.D., and Edmond, J.M., 1983. The genesis of hot spring deposits on the East Pacific Rise, $21^{\circ} \mathrm{N}$. Econ. Geol. Monogr, 5:184-197.

Goodfellow, W.D., and Blaise, B., 1988. Sulphide formation and hydrothermal alteration of hemipelagic sediment in Middle Valley, northern Juan de Fuca Ridge. Can. Mineral., 26:675-696.

Goodfellow, W.D., and Franklin, J.M., 1993. Geology, mineralogy and geochemistry of massive sulfides in shallow cores, Middle Valley, Northern Juan de Fuca Ridge. Econ. Geol., 88:2037-2068.

Goodfellow, W.D., Grapes, K., Cameron, B., and Franklin, J.M., 1993. Hydrothermal alteration associated with massive sulfide deposits, Middle Valley, Northern Juan de Fuca Ridge. Can. Mineral., 31:1025-1060.

Gresens, R.L., 1967. Composition-volume relationships of metasomatism. Chem. Geol., 2:47-55.

Haymon, R.M., 1983. Growth history of hydrothermal black smoker chimneys. Nature, 301:695-698.

Holtzapffel, T., 1985. Les minéraux argileux: préparation, analyse diffractométrique et détermination. Ann. Soc. Geol. Nord. Publ., 12.

Janecky, D.R., and Shanks, W.C., III, 1988. Computational modeling of chemical and sulfur isotopic reaction processes in seafloor hydrothermal systems: chimneys, massive sulfides, and subjacent alteration zones. Can. Mineral., 26:805-825.
Juniper, S.K., Tunnicliffe, V., and Southward, E.C., 1992. Hydrothermal vents in turbidite sediments on a northeast spreading centre: organisms and substratum at an ocean drilling site. Can. J. Zool., 70:1792-1809.

Leitch, C.H.B., 1991. Preliminary studies of fluid inclusions in barite from the Middle Valley sulphide mounds, northern Juan de Fuca Ridge. Geol. Surv. Can. Curr. Res., 91-1A:27-30.

Leitch, C.H.B., and Day, S.J., 1990. NEWGRES: a turbo PASCAL program to solve a modified version of Gresens' hydrothermal alteration equation. Comput. Geosci., 16:925-932.

Lydon, J.W., Goodfellow, W.D., and Franklin, J.M., 1991. Spatial control and pore water compositions of active and extinct hydrothermal fields in Middle Valley. In Cadet, J.-P., and Picheon, X.L., Eds., Int. Conf. on Fluids in Subduction Zones, Progr. Abstr.

Lydon, J.W., Goodfellow, W.D., and Gregoire, D.C., 1992. Chemical composition of vent and pore fluids in an active hydrothermal discharge zone, Middle Valley, Geol. Surv. Can. Minerals Colloq., Progr. Abstr., 24.

MacLean, W.H., and Kranidiotis, P., 1987. Immobile elements as monitors of mass transfer in hydrothermal alteration: Phelps Dodge massive sulfide deposit, Matagami, Quebec. Econ. Geol., 82:951-962.

Mottl, M.J., and Holland, H.D., 1978. Chemical exchange during hydrothermal alteration of basalt by seawater. I. Experimental results for major and minor components of seawater. Geochim. Cosmochim. Acta, 42:1103-1115.

Oudin, E., 1983. Hydrothermal sulfide deposits of the East Pacific Rise $\left(21^{\circ} \mathrm{N}\right)$. Part 1: descriptive mineralogy. Mar. Min., 4:39-72.

Ramsay, J.G., 1980. The crack-seal mechanism of rock deformation. Nature, 284:135-139.

Seewald, J.S., and Seyfried, W.E., Jr., 1990. The effect of temperature on metal mobility in subseafloor hydrothermal systems: constraints from basalt alteration experiments. Earth Planet. Sci. Lett., 101:388-403.

Seyfried, W.E., Jr., Berndt, M.E., and Seewald, J.S., 1988. Hydrothermal alteration processes at mid-ocean ridges: constraints from diabase alteration experiments, hot-spring fluids and composition of the oceanic crust. Can. Mineral., 26:787-804.

Seyfried, W.E., Jr., Ding, K., and Berndt, M.E., 1991. Phase equilibria constraints on the chemistry of hot spring fluids at mid-ocean ridges. Geochim. Cosmochim. Acta, 55:3559-3580.

Seyfried, W.E., Jr., and Mottl, M.J., 1982. Hydrothermal alteration of basalt by seawater under seawater-dominated conditions. Geochim. Cosmochim. Acta, 46:985-1002.

Simoneit, B.R.T., 1984. Hydrothermal effects on organic matter-high versus low temperature components. In Schenck, P.A., deLeeuw, J.W., and Lijmbach, G.W.M. (Eds.), Advances in Organic Geochemistry 1983: Oxford (Pergamon Press), 857-864.

Simoneit, B.R.T., Goodfellow, W.D., and Franklin, J.M., 1992. Hydrothermal petroleum at the seafloor and organic matter alteration in sediments of Middle Valley, northern Juan de Fuca Ridge. Appl. Geochem., 7:257-264.

Tsunogai, S., Yonemaru, I., and Kusakabe, M., 1979. Post depositional migration of $\mathrm{Cu}, \mathrm{Zn}, \mathrm{Ni}, \mathrm{Co}, \mathrm{Pb}$ and $\mathrm{Ba}$ in deep sea sediments. Geochem. J., 13:239-252.

Turner, R.J.W., Ames, D.E., Goodfellow, W.D., Leitch, C.H.B., Franklin, J.M., and Hoy, T., 1993. Character of active hydrothermal mounds and nearby altered hemipelagic sediments in the hydrothermal areas of Middle Valley, northern Juan de Fuca Ridge: shallow core data. Can. Mineral., 31:973995.

Turner, R.J.W., Leitch, C.H.B., Ames, D.E., Hoy, T., Franklin, J.M., and Goodfellow, W.D., 1991. Character of hydrothermal mounds and adjacent sediments, active hydrothermal areas, Middle Valley sedimented rift, northern Juan de Fuca Ridge, northeast Pacific: evidence from $A L V I N$ push cores. Geol. Surv. Can. Curr. Res., Pt. E., 99-108.

Von Damm, K.L., 1990. Seafloor hydrothermal activity: black smoker chemistry and chimneys. Annu. Rev. Earth Planet. Sci., 18:173-204.

Von Damm, K.L., Edmond, J.M., Grant, B., Measures, C.I., Walden, B., and Weiss, R.F., 1985. Chemistry of submarine hydrothermal solutions at $21^{\circ} \mathrm{N}$, East Pacific Rise. Geochim. Cosmochim. Acta, 49:2207-2220.

Winchester, J.A., and Floyd, P.A., 1976. Geochemical magma type discrimination: application to altered and metamorphosed basic igneous rocks. Earth Planet. Sci. Lett., 28:459-469.

Date of initial receipt: 6 March 1993

Date of acceptance: 31 August 1993

Ms 139SR-219 


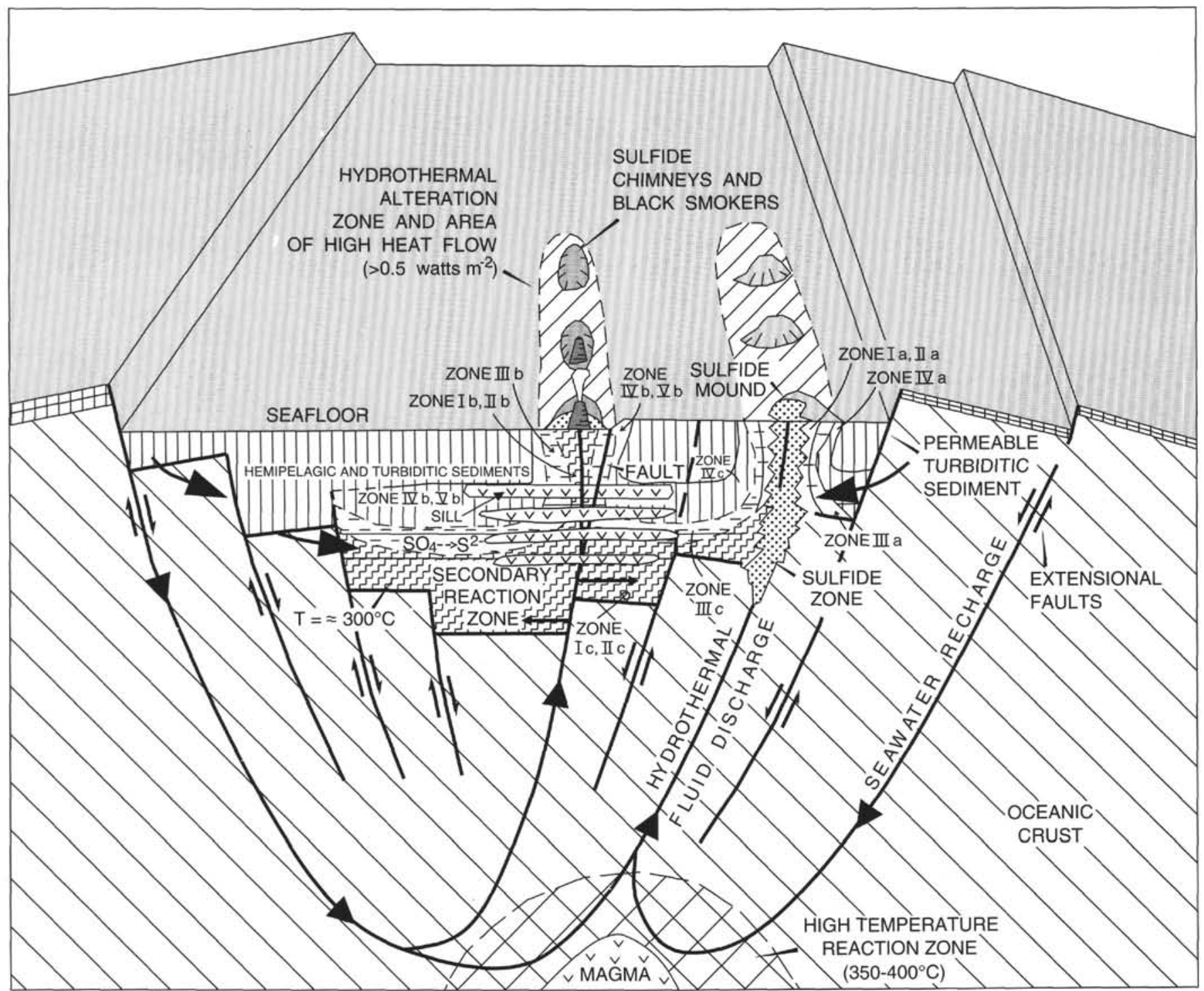

Figure 28. Schematic block diagram of the Middle Valley hydrothermal system showing the inactive hydrothermal fluid upflow zone, related alteration, and associated massive sulfide deposit at BH (Site 856), the active hydrothermal fluid upflow zone and associated alteration at the AAV (Site 858), and hydrothermal reaction zone below $450 \mathrm{mbsf}$ at Site 857. Also shown is an inferred high-temperature reaction zone associated with a magma body at depth, and fluid flow directions (modified from Goodfellow and Franklin, 1993). 
Table 1. Major and minor element analyses of sediment and sulfide samples performed at the Geological Survey of Canada and by ODP (Davis, Mottl,

Fisher, et al., 1992).

\begin{tabular}{|c|c|c|c|c|c|c|c|}
\hline & & & & Udepth & Ldepth & Depth & \\
\hline Leg & Hole & Core & Section & $(\mathrm{cm})$ & $(\mathrm{cm})$ & (mbsf) & Lithology \\
\hline 139 & $855 \mathrm{~A}$ & $01 \mathrm{R}$ & 2 & 77 & 79 & 2.27 & SLCY \\
\hline 139 & $855 \mathrm{~A}$ & $01 R$ & 4 & 70 & 74 & 5.20 & SLCY \\
\hline 139 & $855 \mathrm{~A}$ & OIR & 4 & 111 & 114 & 5.61 & SLCY \\
\hline 139 & $855 \mathrm{~A}$ & $02 R$ & 1 & 71 & 73 & 8.31 & SLCY \\
\hline 139 & $855 \mathrm{~A}$ & $02 R$ & 3 & 42 & 44 & 11.02 & SAND \\
\hline 139 & $855 \mathrm{~A}$ & $02 \mathrm{R}$ & 3 & 69 & 71 & 11.29 & SLCY \\
\hline 139 & $855 \mathrm{~A}$ & 03R & 2 & 80 & 82 & 18.90 & SLCY \\
\hline 139 & $855 \mathrm{~A}$ & $04 R$ & 1 & 112 & 115 & 27.12 & SLCY \\
\hline 139 & $855 \mathrm{~A}$ & O4R & 3 & 96 & 98 & 29.96 & SLCY \\
\hline 139 & $855 \mathrm{~A}$ & $04 \mathrm{R}$ & 4 & 81 & 83 & 31.31 & SLCY \\
\hline 139 & $855 \mathrm{~A}$ & $05 R$ & 1 & 4 & 6 & 35.54 & SLCY \\
\hline 139 & $855 \mathrm{~A}$ & 06R & 1 & 100 & 104 & 46.50 & SLCY \\
\hline 139 & $855 \mathrm{~A}$ & $07 R$ & 3 & 65 & 67 & 58.75 & SNSL \\
\hline 139 & $855 \mathrm{~B}$ & $02 R$ & 1 & 106 & 110 & 6.76 & SLCY \\
\hline 139 & $855 \mathrm{~B}$ & $04 R$ & 1 & 128 & 132 & 25.78 & SLCY \\
\hline 139 & $855 B$ & $04 R$ & 3 & 122 & 126 & 28.72 & SLCY \\
\hline 139 & $855 B$ & $04 \mathrm{R}$ & 4 & 57 & 61 & 29.57 & SNCL \\
\hline 139 & $855 B$ & $04 \mathrm{R}$ & 4 & 99 & 102 & 29.99 & SILT \\
\hline 139 & $855 B$ & $04 R$ & 5 & 118 & 122 & 31.68 & SLCY \\
\hline 139 & $855 \mathrm{~B}$ & $05 R$ & 1 & 25 & 28 & 34.25 & SAND \\
\hline 139 & $855 C$ & $01 R$ & 1 & 57 & 61 & 0.57 & SLCY \\
\hline 139 & $855 \mathrm{C}$ & $01 R$ & 3 & 55 & 57 & 3.55 & SLCY \\
\hline 139 & $855 \mathrm{C}$ & $01 R$ & 5 & 56 & 58 & 6.56 & SLCY \\
\hline 139 & $855 \mathrm{C}$ & $02 \mathrm{R}$ & 1 & 53 & 57 & 9.23 & SLCY \\
\hline 139 & $855 \mathrm{C}$ & $02 R$ & 3 & 54 & 58 & 12.24 & SLCY \\
\hline 139 & $855 \mathrm{C}$ & $02 R$ & 5 & 52 & 56 & 15.22 & SLCY \\
\hline 139 & $855 C$ & $03 R$ & 1 & 45 & 47 & 18.15 & SLCY \\
\hline 139 & $855 \mathrm{C}$ & $04 \mathrm{R}$ & 1 & 87 & 89 & 27.97 & SLCY \\
\hline 139 & $855 C$ & $04 R$ & 3 & 103 & 105 & 31.13 & SLCY \\
\hline 139 & $855 \mathrm{C}$ & 06R & 1 & 128 & 132 & 47.78 & SLCY \\
\hline 139 & $855 C$ & 06R & 2 & 2 & 6 & 48.02 & SLCY \\
\hline 139 & $855 \mathrm{C}$ & 06R & 3 & 130 & 134 & 50.80 & SLCY \\
\hline 139 & $855 \mathrm{C}$ & 06R & 5 & 76 & 80 & 53.26 & SLCY \\
\hline 139 & $855 \mathrm{C}$ & $07 \mathrm{R}$ & 1 & 76 & 80 & 56.86 & SLCY \\
\hline 139 & $855 \mathrm{C}$ & $07 R$ & 2 & 83 & 87 & 58.43 & SLCY \\
\hline 139 & $855 C$ & $07 R$ & 4 & 80 & 84 & 61.40 & SLCY \\
\hline 139 & $855 \mathrm{C}$ & $07 R$ & 6 & 60 & 64 & 64.20 & SLCY \\
\hline 139 & $855 \mathrm{C}$ & 08R & 2 & 33 & 36 & 66.78 & SILT \\
\hline 139 & $855 C$ & $08 \mathrm{R}$ & 2 & 40 & 44 & 66.85 & SLCY \\
\hline 139 & $855 C$ & IOR & 1 & 130 & 134 & 86.20 & SLCY \\
\hline 139 & $855 \mathrm{C}$ & $10 \mathrm{R}$ & 4 & 51 & 55 & 88.41 & SLCY \\
\hline 139 & $855 C$ & IOR & 5 & 43 & 47 & 89.83 & SLCY \\
\hline 139 & $855 \mathrm{C}$ & $11 \mathrm{R}$ & 1 & 67 & 70 & 95.27 & SAND \\
\hline 139 & $855 \mathrm{C}$ & $11 \mathrm{R}$ & 1 & 115 & 119 & 95.75 & SAND \\
\hline 139 & $856 \mathrm{~A}$ & $\mathrm{OIH}$ & 1 & 69 & 72 & 0.69 & SLCY \\
\hline 139 & $856 \mathrm{~A}$ & $\mathrm{OIH}$ & 1 & 95 & 98 & 0.95 & SLCY \\
\hline 139 & $856 \mathrm{~A}$ & $02 \mathrm{H}$ & 1 & 45 & 47 & 3.15 & SLCY \\
\hline 139 & $856 \mathrm{~A}$ & $\mathrm{O} 2 \mathrm{H}$ & 2 & 62 & 64 & 4.82 & SLCY \\
\hline 139 & $856 \mathrm{~A}$ & $03 \mathrm{H}$ & 1 & 107 & 111 & 13.27 & SLCY \\
\hline 139 & $856 \mathrm{~A}$ & $03 \mathrm{H}$ & 2 & 67 & 71 & 14.37 & SLCY \\
\hline 139 & $856 \mathrm{~A}$ & $03 \mathrm{H}$ & 5 & 117 & 121 & 19.37 & SLCY \\
\hline 139 & $856 \mathrm{~A}$ & $03 \mathrm{H}$ & 6 & 8 & 9 & 19.78 & ND \\
\hline 139 & $856 \mathrm{~A}$ & $03 \mathrm{H}$ & 7 & 12 & 16 & 21.32 & SLCY \\
\hline 139 & $856 \mathrm{~A}$ & $04 \mathrm{H}$ & 2 & 37 & 41 & 23.57 & SLCY \\
\hline 139 & $856 \mathrm{~A}$ & $04 \mathrm{H}$ & 2 & 86 & 90 & 24.06 & SILT \\
\hline 139 & $856 \mathrm{~A}$ & $04 \mathrm{H}$ & 4 & 36 & 40 & 26.56 & SAND \\
\hline 139 & $856 \mathrm{~A}$ & $04 \mathrm{H}$ & 6 & 55 & 59 & 29.75 & SAND \\
\hline 139 & $856 \mathrm{~A}$ & $05 \mathrm{H}$ & 2 & 73 & 77 & 32.31 & SAND \\
\hline 139 & $856 \mathrm{~A}$ & $05 \mathrm{H}$ & 3 & 73 & 77 & 33.81 & SAND \\
\hline 139 & $856 \mathrm{~A}$ & $05 \mathrm{H}$ & 4 & 91 & 95 & 35.49 & SLCY \\
\hline 139 & $856 \mathrm{~A}$ & $05 \mathrm{H}$ & 5 & 29 & 31 & 36.37 & SLCY \\
\hline 139 & $856 \mathrm{~A}$ & $05 \mathrm{H}$ & 8 & 71 & 75 & 41.29 & SAND \\
\hline 139 & $856 \mathrm{~A}$ & $06 \mathrm{H}$ & 1 & 79 & 84 & 41.49 & SNSL \\
\hline 139 & $856 \mathrm{~A}$ & $06 \mathrm{H}$ & 2 & 88 & 92 & 43.08 & SAND \\
\hline 139 & $856 \mathrm{~A}$ & $06 \mathrm{H}$ & 2 & 144 & 148 & 43.64 & SLCY \\
\hline 139 & $856 \mathrm{~A}$ & $06 \mathrm{H}$ & 3 & 103 & 107 & 44.73 & SLCY \\
\hline 139 & $856 \mathrm{~A}$ & $06 \mathrm{H}$ & 4 & 69 & 77 & 45.89 & SAND \\
\hline 139 & $856 \mathrm{~A}$ & $06 \mathrm{H}$ & 4 & 89 & 94 & 46.09 & SNSL \\
\hline 139 & $856 \mathrm{~A}$ & $06 \mathrm{H}$ & 5 & 104 & 106 & 47.74 & SLCY \\
\hline 139 & $856 \mathrm{~A}$ & $06 \mathrm{H}$ & 6 & 90 & 94 & 49.10 & SNSL \\
\hline 139 & $856 \mathrm{~A}$ & $06 \mathrm{H}$ & 7 & 61 & 65 & 50.31 & SNSL \\
\hline 139 & $856 \mathrm{~A}$ & 07H & 1 & 89 & 93 & 51.09 & SLCY \\
\hline 139 & $856 \mathrm{~A}$ & $07 \mathrm{H}$ & 2 & 95 & 99 & 52.65 & SAND \\
\hline 139 & $856 \mathrm{~A}$ & $07 \mathrm{H}$ & 3 & 0 & 3 & 53.20 & SILT \\
\hline 139 & $856 \mathrm{~A}$ & $07 \mathrm{H}$ & 3 & 81 & 85 & 54.01 & SLCY \\
\hline 139 & $856 \mathrm{~A}$ & $07 \mathrm{H}$ & 5 & 70 & 74 & 56.90 & SLCY \\
\hline 139 & $856 \mathrm{~A}$ & $07 \mathrm{H}$ & 6 & 139 & 142 & 59.09 & SAND \\
\hline 139 & $856 \mathrm{~A}$ & $07 \mathrm{H}$ & 7 & 55 & 59 & 59.75 & SLCY \\
\hline 139 & $856 \mathrm{~A}$ & $07 \mathrm{H}$ & 0 & 24 & 28 & 60.20 & SLCY \\
\hline 139 & $856 \mathrm{~A}$ & $08 \mathrm{H}$ & 1 & 4 & 6 & 59.74 & SNSL \\
\hline 139 & $856 \mathrm{~A}$ & $08 \mathrm{H}$ & 1 & 8 & 10 & 59.78 & SLCY \\
\hline 139 & $856 \mathrm{~A}$ & $08 \mathrm{H}$ & 1 & 97 & 99 & 60.67 & SLCY \\
\hline 139 & $856 \mathrm{~A}$ & $08 \mathrm{H}$ & 3 & 23 & 26 & 62.93 & SILT \\
\hline 139 & $856 \mathrm{~A}$ & $08 \mathrm{H}$ & 3 & 66 & 68 & 63.36 & SLCY \\
\hline 139 & $856 \mathrm{~A}$ & $08 \mathrm{H}$ & 3 & 72 & 75 & 63.42 & SLCY \\
\hline 139 & $856 \mathrm{~A}$ & $08 \mathrm{H}$ & 5 & 84 & 87 & 66.54 & SLCY \\
\hline 139 & $856 \mathrm{~A}$ & $08 \mathrm{H}$ & 7 & 26 & 28 & 68.96 & SLCY \\
\hline 139 & $856 \mathrm{~A}$ & $\mathrm{O9H}$ & 1 & 4 & 47 & 69.64 & SLCY \\
\hline 139 & $856 \mathrm{~A}$ & $\mathrm{O9H}$ & 1 & 10 & 13 & 69.30 & SLCY \\
\hline
\end{tabular}


Table 1 (continued).

\begin{tabular}{|c|c|c|c|c|c|c|c|}
\hline $\mathrm{CaO}$ & $\mathrm{Na}_{2} \mathrm{O}$ & $\mathrm{Na}_{2} \mathrm{OC}$ & $\mathrm{K}_{2} \mathrm{O}$ & $\mathrm{P}_{212} \mathrm{O}_{5}$ & $\mathrm{H}_{2} \mathrm{OT}$ & $\mathrm{S}$ & $\mathrm{CO}_{2} \mathrm{~T}$ \\
\hline & & & & & & & \\
\hline 4.63 & 3.40 & 2.11 & 2.36 & 0.21 & 3.60 & 0.24 & 3.70 \\
\hline 4.61 & 3.90 & 2.46 & 2.11 & 0.20 & 3.10 & 0.27 & 2.70 \\
\hline 5.00 & 2.27 & ND & 2.22 & 0.20 & 5.04 & 0.14 & 3.11 \\
\hline 3.94 & 3.70 & 2.41 & 2.27 & 0.20 & 3.50 & 0.10 & 2.90 \\
\hline 4.32 & 1.79 & ND & 2.56 & 0.18 & 3.42 & 0.00 & 3.12 \\
\hline 3.35 & 3.20 & 2.22 & 2.91 & 0.18 & 3.20 & 0.12 & 2.50 \\
\hline 3.05 & 2.04 & ND & 2.21 & 0.20 & 5.31 & 0.18 & ND \\
\hline 4.15 & 4.00 & 2.68 & 2.28 & 0.19 & 3.70 & 0.40 & 3.00 \\
\hline 7.44 & 3.50 & 2.48 & 1.96 & 0.21 & 4.20 & 0.41 & 5.30 \\
\hline 3.48 & 3.40 & 2.58 & 1.89 & 0.19 & 4.60 & 0.24 & 2.30 \\
\hline 3.67 & 4.00 & 2.73 & 1.99 & 0.18 & 4.20 & 0.19 & 1.60 \\
\hline 4.33 & 3.80 & ND & 1.68 & 0.19 & 3.10 & 0.15 & 1.40 \\
\hline 4.64 & 3.60 & 2.49 & 1.98 & 0.13 & 4.70 & 0.54 & 4.50 \\
\hline 6.92 & 3.50 & 2.04 & 2.22 & 0.19 & 4.50 & 0.14 & 5.60 \\
\hline 3.73 & 3.80 & 2.86 & 1.88 & 0.19 & 3.80 & 0.16 & 2.00 \\
\hline 3.63 & 3.70 & 2.69 & 1.96 & 0.19 & 3.90 & 0.22 & 2.10 \\
\hline 4.42 & 3.80 & ND & 1.38 & 0.18 & 2.30 & 0.19 & 1.10 \\
\hline 4.08 & 2.73 & ND & 1.69 & 0.22 & 3.51 & 0.32 & 1.80 \\
\hline 8.26 & 3.50 & 2.99 & 1.98 & 0.19 & 4.40 & 0.15 & 6.30 \\
\hline 4.66 & 3.04 & ND & 1.53 & 0.19 & 2.07 & 0.19 & 1.03 \\
\hline 5.70 & 3.80 & 2.18 & 2.45 & 0.19 & 3.60 & 0.20 & 5.30 \\
\hline 5.70 & 3.70 & 3.07 & 2.09 & 0.20 & 3.10 & 0.19 & 3.60 \\
\hline 5.09 & 4.00 & 2.99 & 2.04 & 0.19 & 2.50 & 0.15 & 2.70 \\
\hline 4.42 & 3.90 & 2.67 & 2.03 & 0.19 & 4.30 & 0.13 & 3.30 \\
\hline 3.31 & 3.40 & 2.13 & 2.77 & 0.19 & 4.60 & 0.13 & 2.80 \\
\hline 3.25 & 3.80 & ND & 2.40 & 0.17 & 5.60 & 0.24 & 3.50 \\
\hline 4.61 & 3.70 & 3.23 & 2.26 & 0.18 & 4.10 & 0.36 & 3.80 \\
\hline 3.07 & 4.00 & 2.67 & 2.24 & 0.18 & 3.10 & 0.22 & 1.70 \\
\hline 3.72 & 3.90 & 2.66 & 2.18 & 0.20 & 4.70 & 0.19 & 2.00 \\
\hline 3.35 & 3.80 & 2.72 & 1.94 & 0.20 & 4.90 & 0.15 & 2.10 \\
\hline 11.90 & 3.00 & ND & 0.14 & 0.18 & 0.80 & 0.11 & 0.10 \\
\hline 3.67 & 3.80 & 2.76 & 1.87 & 0.23 & 1.50 & 0.20 & 2.10 \\
\hline 3.80 & 2.42 & ND & 1.97 & 0.20 & 3.69 & 0.20 & 1.83 \\
\hline 2.81 & 2.07 & ND & 2.07 & 0.18 & 5.67 & 0.28 & 1.50 \\
\hline 3.47 & 3.60 & ND & 2.21 & 0.19 & 5.20 & 0.13 & 2.00 \\
\hline 4.93 & 3.70 & ND & 1.76 & 0.23 & 4.00 & 0.36 & 2.40 \\
\hline 4.24 & 3.80 & ND & 1.81 & 0.19 & 4.80 & 0.52 & 1.90 \\
\hline 3.83 & 2.60 & ND & 1.91 & 0.20 & 4.32 & 0.22 & 1.58 \\
\hline 3.40 & 3.80 & ND & 1.92 & 0.19 & 4.60 & 0.94 & 1.10 \\
\hline 3.10 & 3.20 & 2.43 & 2.47 & 0.21 & 4.00 & 0.20 & 2.50 \\
\hline 4.06 & 3.70 & 3.21 & 1.64 & 0.19 & 2.90 & 0.31 & 1.40 \\
\hline 3.34 & 2.19 & ND & 2.26 & 0.23 & 4.95 & 0.24 & 2.56 \\
\hline 4.70 & 3.16 & ND & 1.38 & 0.18 & 2.25 & 0.18 & 1.17 \\
\hline 4.89 & 4.00 & 3.61 & 1.35 & 0.17 & 1.90 & 0.25 & 1.00 \\
\hline 8.83 & 2.07 & ND & 2.19 & 0.17 & 5.40 & 0.15 & 7.46 \\
\hline 8.30 & 3.90 & ND & 2.12 & 0.18 & 4.60 & 0.16 & 6.40 \\
\hline 3.51 & 3.80 & ND & 2.22 & 0.19 & 4.50 & 0.12 & 1.90 \\
\hline 3.36 & 1.97 & ND & 2.51 & 0.17 & 6.48 & 0.23 & 4.32 \\
\hline 3.60 & 2.90 & ND & 2.49 & 0.19 & 2.50 & 0.28 & 2.70 \\
\hline 4.13 & 1.83 & ND & 2.47 & 0.21 & 3.78 & 0.20 & 3.22 \\
\hline 2.70 & 3.50 & 2.45 & 2.10 & 0.17 & ND & 1.34 & 2.10 \\
\hline 25.60 & 1.89 & ND & 0.71 & 0.18 & ND & ND & ND \\
\hline 3.01 & 3.20 & ND & 2.46 & 0.23 & 3.80 & 0.21 & 2.10 \\
\hline 3.92 & 3.10 & 2.53 & 2.32 & 0.20 & 2.90 & 0.16 & 2.20 \\
\hline 3.05 & 2.03 & ND & 2.97 & 0.22 & 3.69 & 0.16 & 2.27 \\
\hline 4.19 & 3.30 & ND & 1.99 & 0.20 & 2.00 & 0.09 & 1.80 \\
\hline 4.87 & 3.40 & 3.01 & 1.52 & 0.22 & 1.80 & 0.11 & 1.90 \\
\hline 4.10 & 3.30 & 2.84 & 1.75 & 0.17 & 2.10 & 0.13 & 1.90 \\
\hline 3.67 & 2.25 & ND & 1.95 & 0.20 & 3.24 & 0.00 & 2.61 \\
\hline 3.68 & 3.10 & 2.35 & 2.44 & 0.21 & 4.40 & 0.36 & 2.90 \\
\hline 4.21 & 3.10 & 2.35 & 2.36 & 0.20 & 3.70 & 0.14 & 2.90 \\
\hline 3.69 & 3.20 & 2.70 & 2.01 & 0.19 & 2.50 & 0.30 & 1.90 \\
\hline 4.31 & 3.30 & 2.84 & 1.95 & 0.19 & 2.10 & 0.17 & 2.10 \\
\hline 4.36 & 2.66 & 2.62 & 1.89 & 0.19 & 2.25 & 0.25 & 2.01 \\
\hline 5.24 & 3.00 & 2.19 & 2.59 & 0.21 & 4.00 & 0.10 & 3.70 \\
\hline 3.53 & 3.10 & 2.49 & 2.30 & 0.19 & 3.10 & 0.14 & 2.20 \\
\hline 12.30 & 2.80 & 2.56 & 1.51 & 0.16 & 1.60 & 0.63 & 8.20 \\
\hline 3.74 & 3.60 & 3.16 & 1.51 & 0.18 & 1.90 & 0.39 & 1.50 \\
\hline 1.81 & 3.10 & 2.41 & 2.67 & 0.21 & 4.50 & 0.18 & 1.40 \\
\hline 3.85 & 3.50 & 3.12 & 1.50 & 0.17 & 2.30 & 0.96 & 1.70 \\
\hline 3.25 & 3.40 & 2.83 & 1.64 & 0.21 & 3.30 & 0.77 & 1.50 \\
\hline 4.12 & 3.00 & 2.37 & 2.49 & 0.18 & 3.90 & 0.26 & 3.20 \\
\hline 3.76 & 2.78 & ND & 1.58 & 0.19 & 2.43 & 0.50 & 1.72 \\
\hline 3.31 & 3.80 & ND & 1.74 & 0.18 & 2.90 & 0.20 & 1.20 \\
\hline 1.44 & 3.30 & 2.52 & 2.65 & 0.19 & 4.40 & 0.15 & 1.30 \\
\hline 1.55 & 3.40 & 2.71 & 2.20 & 0.24 & 4.50 & 0.13 & 1.30 \\
\hline 2.32 & 3.70 & 3.23 & 1.65 & 0.19 & ND & 1.24 & 0.60 \\
\hline 1.94 & 3.60 & 2.98 & 2.10 & 0.19 & 3.10 & 0.51 & 1.00 \\
\hline 29.60 & 0.70 & ND & 0.26 & 0.45 & 5.70 & 0.12 & 24.20 \\
\hline 29.90 & 1.20 & 0.85 & 0.55 & 0.45 & 3.40 & 0.14 & 23.50 \\
\hline 9.60 & 3.10 & 2.45 & 0.98 & 0.32 & 3.40 & 0.43 & 6.40 \\
\hline 1.65 & 3.40 & ND & 2.22 & 0.19 & 4.20 & 0.24 & 1.20 \\
\hline 3.00 & 3.80 & 3.37 & 1.38 & 0.18 & 0.00 & 1.02 & 0.70 \\
\hline 1.27 & 2.09 & ND & 2.36 & 0.18 & 4.59 & 0.20 & 1.39 \\
\hline 1.76 & 3.50 & 2.87 & 2.02 & 0.20 & 4.30 & 0.17 & 1.10 \\
\hline 1.66 & 3.40 & 2.63 & 2.00 & 0.24 & 4.40 & 0.25 & 1.10 \\
\hline 1.86 & 3.50 & 2.83 & 1.95 & 0.27 & 3.70 & 0.23 & 1.10 \\
\hline 9.28 & 2.60 & ND & 1.39 & 0.17 & 0.00 & 1.53 & 6.70 \\
\hline 8.30 & 2.80 & 221 & 208 & 0.19 & 370 & 0.24 & 6.40 \\
\hline
\end{tabular}


Table 1 (continued).

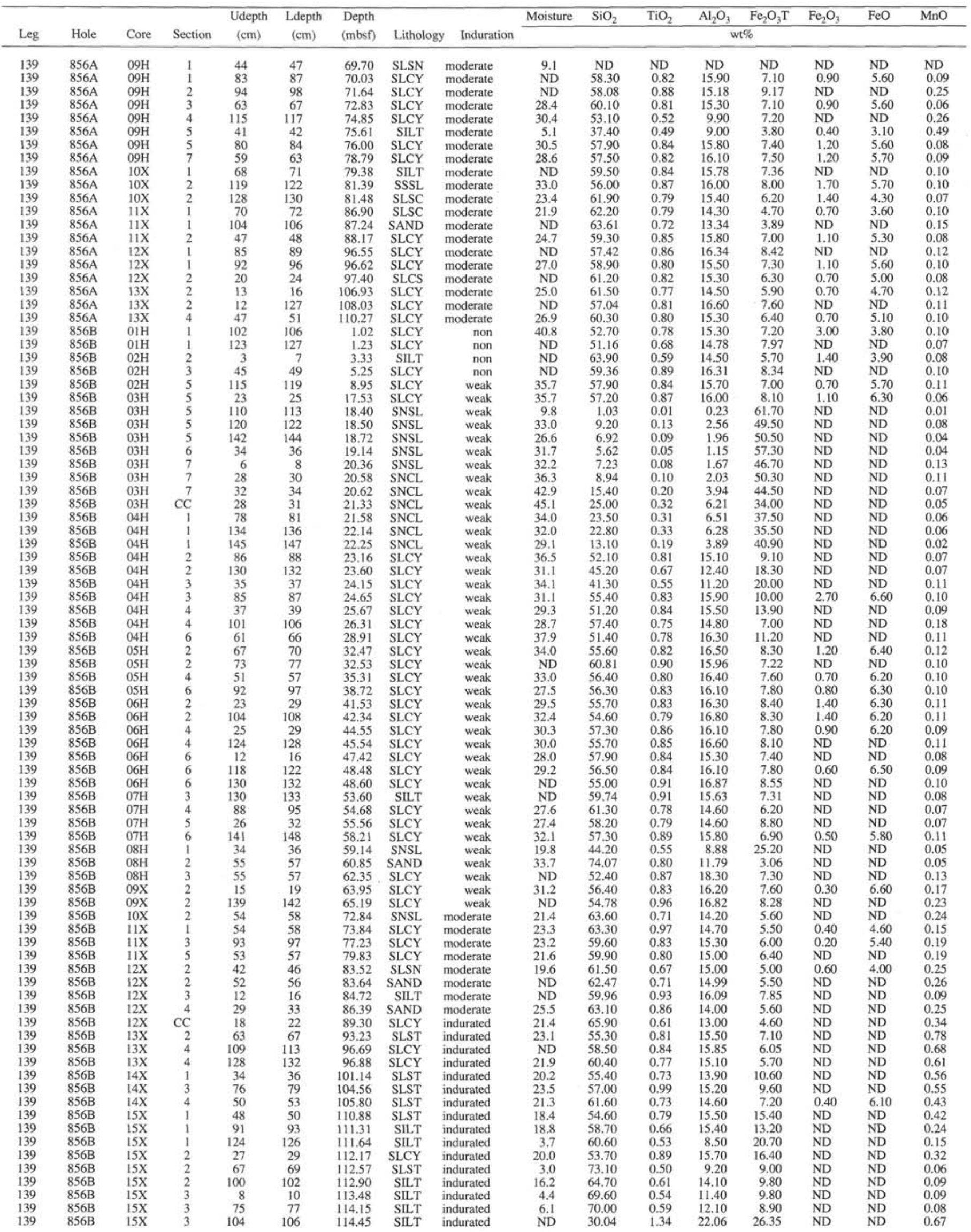


Table 1 (continued).

\begin{tabular}{|c|c|c|c|c|c|c|c|c|}
\hline $\mathrm{MgO}$ & $\mathrm{CaO}$ & $\mathrm{Na}_{2} \mathrm{O}$ & $\mathrm{Na}_{2} \mathrm{OC}$ & $\mathrm{K}_{2} \mathrm{O}$ & $\mathrm{P}_{212} \mathrm{O}_{5}$ & $\mathrm{H}_{2} \mathrm{OT}$ & $S$ & $\mathrm{CO}_{2} \mathrm{~T}$ \\
\hline & & & & & & & & \\
\hline ND & ND & ND & 0.00 & ND & ND & ND & ND & ND \\
\hline 4.67 & 2.36 & 3.40 & 2.67 & 2.07 & 0.21 & 3.50 & 0.15 & 1.50 \\
\hline 8.76 & 0.36 & 1.95 & ND & 1.16 & 0.22 & 3.42 & 0.00 & 0.00 \\
\hline 4.72 & 1.28 & 3.00 & 2.27 & 2.32 & 0.17 & 4.10 & 0.09 & 1.10 \\
\hline 1.76 & 10.90 & 2.40 & 2.12 & 1.26 & 0.12 & 0.00 & 3.60 & 7.90 \\
\hline 2.18 & 22.90 & 1.90 & 1.64 & 1.27 & 0.18 & 2.10 & 0.60 & 17.60 \\
\hline 5.06 & 1.74 & 3.20 & 2.47 & 2.21 & 0.24 & 4.10 & 0.32 & 1.10 \\
\hline 5.42 & 1.67 & 3.40 & 2.74 & 1.96 & 0.19 & 4.50 & 0.16 & 1.00 \\
\hline 5.55 & 1.60 & 2.46 & ND & 1.88 & 0.19 & 2.70 & 0.56 & 0.63 \\
\hline 5.71 & 2.08 & 3.70 & 2.86 & 1.76 & 0.48 & 4.40 & 0.15 & 0.90 \\
\hline 3.81 & 2.83 & 3.90 & 3.39 & 1.39 & 0.26 & 2.60 & 0.18 & 0.50 \\
\hline 2.50 & 4.62 & 3.50 & 3.04 & 1.54 & 0.20 & 2.00 & 0.30 & 2.10 \\
\hline 1.60 & 7.00 & 2.84 & ND & 1.49 & 0.17 & 1.89 & 0.30 & 0.00 \\
\hline 4.96 & 1.54 & 3.20 & 2.66 & 2.13 & 0.19 & 3.80 & 0.24 & 1.10 \\
\hline 7.52 & 0.79 & 2.02 & ND & 2.20 & 0.19 & 4.50 & 0.17 & 0.88 \\
\hline 5.54 & 1.18 & 3.20 & 2.62 & 2.01 & 0.30 & 4.40 & 0.56 & 0.80 \\
\hline 4.83 & 1.37 & 3.10 & ND & 1.91 & 0.23 & 4.20 & 0.25 & 0.70 \\
\hline 5.83 & 1.20 & 3.60 & 3.10 & 1.62 & 0.20 & 3.50 & 0.38 & 0.40 \\
\hline 7.77 & 0.53 & 1.95 & ND & 2.31 & 0.17 & 5.31 & 0.29 & 1.03 \\
\hline 6.27 & 1.07 & 3.60 & 3.11 & 1.07 & 0.21 & 3.70 & 0.25 & 0.50 \\
\hline 3.81 & 6.18 & 3.80 & 2.59 & 2.06 & 0.18 & 4.00 & 0.13 & 4.20 \\
\hline 3.64 & 7.72 & 1.81 & ND & 2.55 & 0.14 & 5.22 & 0.42 & 0.00 \\
\hline 2.70 & 4.02 & 3.40 & 2.73 & 1.89 & 0.15 & 1.50 & 0.50 & 0.40 \\
\hline 3.86 & 3.41 & 2.52 & ND & 2.27 & 0.18 & 2.70 & 1.19 & 0.88 \\
\hline 3.91 & 3.21 & 3.70 & 2.89 & 1.75 & 0.18 & 3.40 & 0.91 & 1.70 \\
\hline 5.48 & 1.93 & 3.80 & 2.95 & 0.79 & 0.25 & 4.10 & 0.09 & 0.90 \\
\hline 0.54 & 0.14 & 0.20 & 0.19 & 0.09 & 0.04 & ND & 45.00 & 0.40 \\
\hline 5.45 & 1.40 & 1.00 & 0.11 & 0.23 & 0.74 & ND & 31.10 & 0.50 \\
\hline 3.29 & 0.32 & 0.86 & 0.12 & 0.22 & 0.13 & ND & 37.00 & 0.50 \\
\hline 3.88 & 0.31 & 0.68 & 0.00 & 0.24 & 0.07 & ND & 30.20 & 0.40 \\
\hline 3.66 & 2.53 & 0.89 & 0.01 & 0.27 & 0.21 & ND & 29.00 & 0.90 \\
\hline 2.88 & 0.41 & 1.16 & 0.08 & 0.29 & 0.18 & ND & 36.00 & 0.60 \\
\hline 4.10 & 0.37 & 1.70 & 0.31 & 0.42 & 0.15 & ND & 26.30 & 0.70 \\
\hline 5.50 & 0.50 & 2.29 & ND & 0.63 & 0.23 & ND & 19.40 & 0.70 \\
\hline 4.70 & 0.97 & 1.70 & 0.66 & 0.77 & 0.54 & ND & 23.50 & 0.90 \\
\hline 6.12 & 0.39 & 1.38 & 0.45 & 0.56 & 0.18 & ND & 24.10 & 0.90 \\
\hline 2.96 & 0.49 & 1.07 & 0.23 & 0.54 & 0.20 & ND & 31.80 & 0.90 \\
\hline 4.65 & 0.84 & 3.10 & 2.09 & 2.13 & 0.17 & ND & 3.71 & 1.10 \\
\hline 5.66 & 0.74 & 2.49 & 1.57 & 1.29 & 0.24 & ND & 9.80 & 0.90 \\
\hline 6.56 & 0.60 & 2.11 & 1.14 & 1.27 & 0.16 & ND & 9.40 & 1.30 \\
\hline 4.77 & 1.25 & 3.30 & 2.64 & 2.56 & 0.18 & 4.50 & 0.85 & 1.30 \\
\hline 5.84 & 1.47 & 3.50 & 2.72 & 1.83 & 0.31 & ND & 2.18 & 1.10 \\
\hline 5.27 & 3.77 & 3.50 & ND & 1.90 & 0.39 & ND & 1.54 & 0.70 \\
\hline 5.42 & 0.76 & 2.80 & 2.09 & 3.38 & 0.17 & ND & 3.26 & 1.30 \\
\hline 6.23 & 0.75 & 2.90 & 2.02 & 2.93 & 0.19 & 4.70 & 0.31 & 1.20 \\
\hline 5.21 & 0.92 & 2.22 & ND & 2.88 & 0.19 & 4.14 & 1.06 & 1.06 \\
\hline 6.45 & 0.60 & 2.80 & 1.96 & 2.76 & 0.18 & 4.00 & 0.50 & 0.80 \\
\hline 6.31 & 0.41 & 2.30 & 1.56 & 3.15 & 0.19 & 4.10 & 0.42 & 1.10 \\
\hline 6.94 & 0.34 & 2.20 & 1.46 & 3.01 & 0.18 & 5.30 & 0.49 & 1.10 \\
\hline 7.24 & 0.35 & 2.20 & 1.32 & 3.37 & 0.19 & 4.90 & 0.60 & 0.80 \\
\hline 6.58 & 0.47 & 2.30 & 1.64 & 2.92 & 0.28 & 4.60 & 0.58 & 0.90 \\
\hline 7.08 & 0.35 & 2.20 & ND & 2.74 & 0.20 & ND & 1.32 & 1.00 \\
\hline 6.17 & 0.43 & 2.30 & 1.57 & 2.32 & 0.24 & 4.40 & 0.86 & 0.90 \\
\hline 6.71 & 0.34 & 2.10 & 1.39 & 2.66 & 0.20 & 5.10 & 0.85 & 1.20 \\
\hline 8.23 & 0.34 & 1.18 & ND & 2.75 & 0.20 & 7.02 & 0.63 & 6.81 \\
\hline 7.36 & 0.32 & 1.37 & ND & 2.04 & 0.19 & 4.50 & 1.16 & 1.24 \\
\hline 6.57 & 0.37 & 1.90 & 1.25 & 2.15 & 0.23 & ND & 1.12 & 0.90 \\
\hline 5.84 & 0.29 & 1.90 & 1.29 & 2.15 & 0.18 & ND & 3.50 & 1.00 \\
\hline 7.44 & 0.35 & 2.20 & 1.46 & 2.00 & 0.21 & 4.90 & 0.72 & 1.00 \\
\hline 3.18 & 0.37 & 1.93 & 1.59 & 1.08 & 0.16 & 0.00 & 17.90 & 0.50 \\
\hline 3.44 & 0.36 & 2.55 & ND & 1.08 & 0.18 & 2.61 & 0.35 & 0.44 \\
\hline 9.35 & 0.41 & 1.20 & ND & 2.48 & 0.24 & 5.80 & 0.30 & 0.90 \\
\hline 8.21 & 0.38 & 1.70 & 0.99 & 1.66 & 0.19 & 5.80 & 0.93 & 1.00 \\
\hline 9.32 & 0.45 & 0.28 & ND & 2.38 & 0.23 & 6.12 & 1.28 & 0.11 \\
\hline 5.85 & 0.31 & 3.50 & 3.01 & 0.74 & 0.17 & ND & 1.74 & 0.20 \\
\hline 5.67 & 0.45 & 3.30 & 2.75 & 1.13 & 0.26 & 3.70 & 0.75 & 0.40 \\
\hline 7.13 & 0.42 & 3.60 & 2.97 & 0.83 & 0.25 & 4.60 & 0.87 & 0.50 \\
\hline 7.21 & 0.37 & 2.80 & 2.33 & 1.05 & 0.22 & 0.00 & 1.12 & 0.60 \\
\hline 7.78 & 0.31 & 3.50 & 3.08 & 0.74 & 0.18 & 4.50 & 0.05 & 0.20 \\
\hline 7.45 & 0.36 & 3.16 & ND & 0.71 & 0.17 & 3.78 & 1.48 & 0.00 \\
\hline 5.35 & 1.36 & 2.25 & ND & 2.28 & 0.16 & 5.40 & 1.55 & ND \\
\hline 5.87 & 0.36 & 3.80 & 3.27 & 0.74 & 0.21 & ND & 1.36 & 0.40 \\
\hline 5.64 & 0.27 & 3.40 & 3.05 & 0.59 & 0.16 & ND & 1.59 & 0.80 \\
\hline 8.35 & 0.39 & 4.10 & 3.53 & 0.55 & 0.24 & ND & 2.37 & 0.30 \\
\hline 8.47 & 0.41 & 3.05 & ND & 0.67 & 0.24 & 4.05 & 0.73 & ND \\
\hline 6.88 & 0.35 & 3.90 & 3.48 & 0.71 & 0.19 & 4.30 & 0.80 & 0.50 \\
\hline 7.11 & 0.38 & 0.50 & 0.00 & 2.06 & 0.27 & ND & 4.56 & 0.30 \\
\hline 8.39 & 0.31 & 0.60 & 0.11 & 1.03 & 0.22 & ND & 1.95 & 0.40 \\
\hline 7.91 & 0.25 & 0.50 & 0.10 & 0.53 & 0.18 & 5.90 & 0.12 & 0.50 \\
\hline 5.44 & 0.23 & 0.50 & 0.08 & 1.38 & 0.15 & ND & 1.01 & 0.60 \\
\hline 4.29 & 0.18 & 0.50 & 0.08 & 1.68 & 0.11 & ND & 1.39 & 0.50 \\
\hline 1.84 & 0.20 & 0.20 & 0.11 & 0.05 & 0.13 & ND & 4.81 & 0.20 \\
\hline 4.70 & 0.44 & 0.60 & 0.16 & 1.54 & 0.28 & ND & 1.84 & 0.50 \\
\hline 1.31 & 0.20 & 0.20 & 0.15 & 1.32 & 0.13 & ND & 2.33 & 0.10 \\
\hline 2.74 & 0.30 & 0.60 & 0.20 & 2.06 & 0.20 & ND & 1.21 & 0.70 \\
\hline 1.86 & 0.21 & 0.30 & 0.10 & 1.45 & 0.14 & ND & 1.26 & 0.30 \\
\hline 1.92 & 0.19 & 0.30 & 0.17 & 1.84 & 0.12 & ND & 1.11 & 0.10 \\
\hline 10.29 & 0.17 & 0.00 & ND & 1.65 & 0.04 & 8.10 & 5.48 & 0.48 \\
\hline
\end{tabular}


Table 1 (continued).

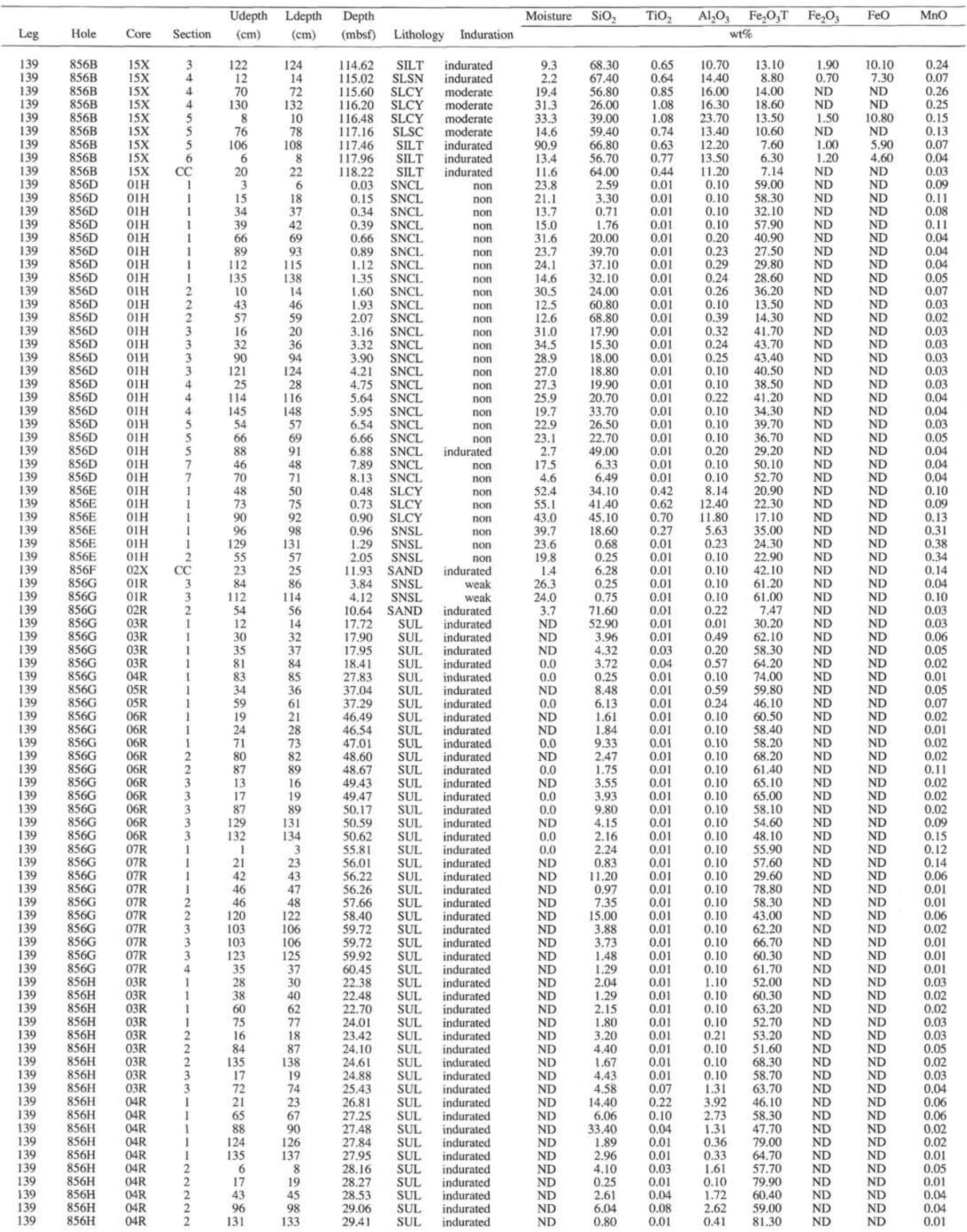


Table 1 (continued).

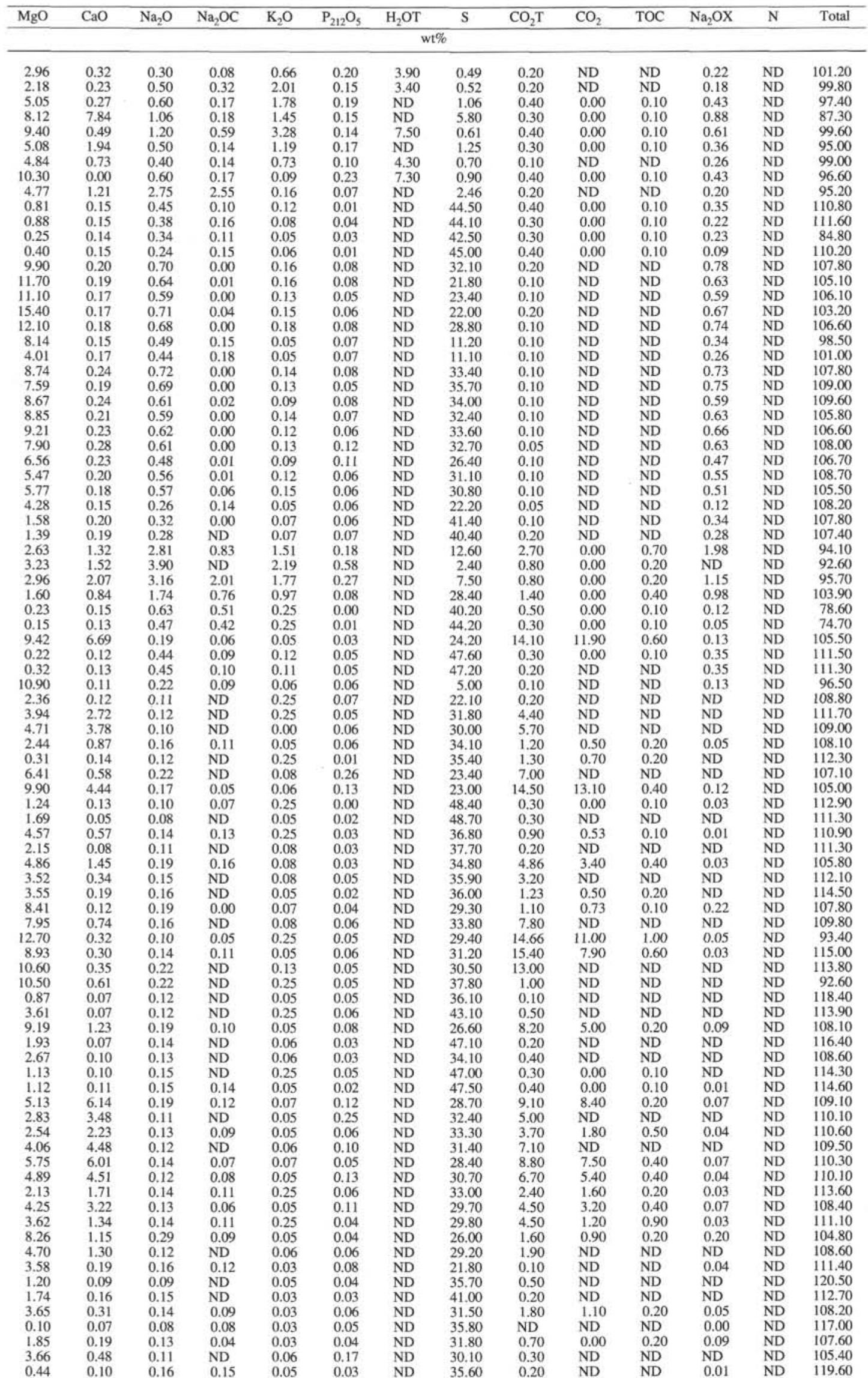


Table 1 (continued).

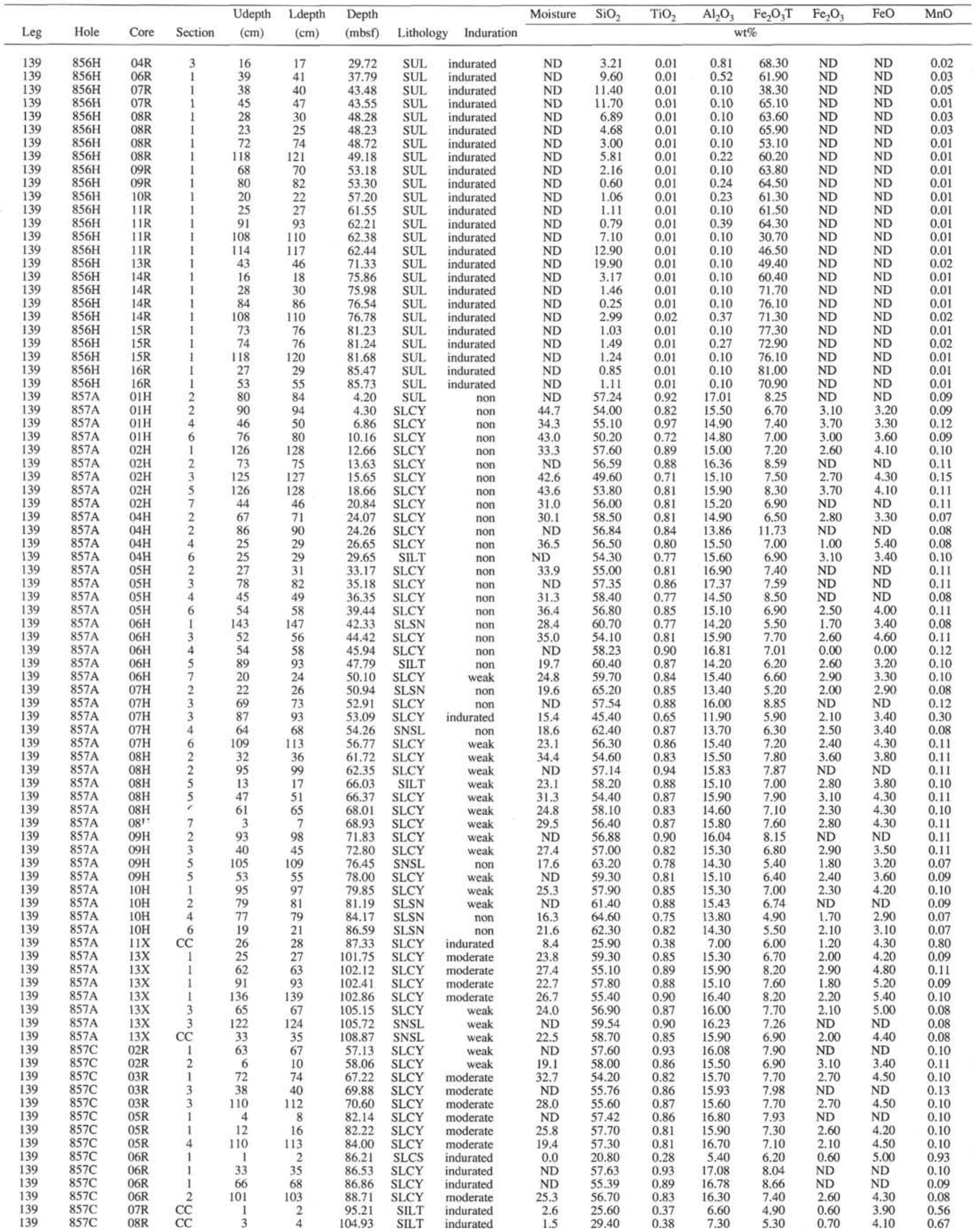


Table 1 (continued).

\begin{tabular}{|c|c|c|c|c|c|c|c|c|}
\hline $\mathrm{MgO}$ & $\mathrm{CaO}$ & $\mathrm{Na}_{2} \mathrm{O}$ & $\mathrm{Na}_{2} \mathrm{OC}$ & $\mathrm{K}_{2} \mathrm{O}$ & $\mathrm{P}_{212} \mathrm{O}_{5}$ & $\mathrm{H}_{2} \mathrm{OT}$ & $\mathrm{S}$ & $\mathrm{CO}_{2} \mathrm{~T}$ \\
\hline & & & & & & & & \\
\hline 2.81 & 0.21 & 0.17 & 0.10 & 0.05 & 0.06 & ND & 33.00 & 0.70 \\
\hline 3.65 & 0.14 & 0.27 & ND & 0.06 & 0.04 & ND & 33.30 & 0.30 \\
\hline 4.12 & 0.32 & 0.29 & ND & 0.09 & 0.04 & ND & 30.40 & 1.80 \\
\hline 2.25 & 0.37 & 0.19 & 0.11 & 0.03 & 0.02 & ND & 33.10 & 0.60 \\
\hline 3.73 & 0.44 & 0.15 & ND & 0.10 & 0.04 & ND & 34.20 & 0.80 \\
\hline 2.30 & 0.18 & 0.15 & ND & 0.03 & 0.02 & ND & 34.20 & 1.60 \\
\hline 1.58 & 0.05 & 0.08 & ND & 0.10 & 0.05 & ND & 45.20 & 0.20 \\
\hline 2.71 & 0.10 & 0.16 & 0.11 & 0.03 & 0.01 & ND & 44.30 & 0.20 \\
\hline 1.18 & 0.12 & 0.14 & 0.11 & 0.03 & 0.03 & ND & 47.80 & 0.30 \\
\hline 0.53 & 0.10 & 0.12 & ND & 0.03 & 0.02 & ND & 50.20 & 0.30 \\
\hline 0.90 & 0.10 & 0.13 & ND & 0.03 & 0.00 & ND & 48.70 & 0.40 \\
\hline 1.10 & 0.10 & 0.10 & ND & 0.03 & 0.04 & ND & 47.90 & 1.10 \\
\hline 0.50 & 0.09 & 0.12 & 0.08 & 0.03 & 0.04 & ND & 48.60 & 0.40 \\
\hline 6.77 & 0.08 & 0.23 & ND & 0.10 & 0.01 & ND & 41.20 & 0.30 \\
\hline 8.62 & 0.19 & 0.27 & 0.19 & 0.05 & 0.08 & ND & 34.30 & 0.20 \\
\hline 9.80 & 0.10 & 0.16 & ND & 0.12 & 0.07 & ND & 30.10 & 0.10 \\
\hline 2.58 & 0.09 & 0.10 & ND & 0.14 & 0.04 & ND & 46.40 & 0.50 \\
\hline 1.28 & 0.12 & 0.15 & ND & 0.05 & 0.02 & ND & 34.10 & 0.10 \\
\hline 0.38 & 0.10 & 0.12 & 0.04 & 0.05 & 0.03 & ND & 34.70 & 0.20 \\
\hline 2.67 & 1.10 & 0.14 & 0.05 & 0.06 & 0.07 & ND & 33.30 & 0.70 \\
\hline 0.99 & 0.07 & 0.10 & ND & 0.03 & 0.01 & ND & 35.40 & 0.20 \\
\hline 1.40 & 0.09 & 0.12 & 0.05 & 0.03 & 0.02 & ND & 34.50 & 0.10 \\
\hline 1.01 & 0.11 & 0.11 & 0.02 & 0.03 & 0.03 & ND & 35.30 & 0.20 \\
\hline 0.84 & 0.12 & 0.15 & 0.10 & 0.03 & 0.04 & ND & 35.40 & 0.50 \\
\hline 0.67 & 0.15 & 0.14 & 0.10 & 0.05 & 0.03 & ND & 35.40 & 0.50 \\
\hline 3.57 & 2.86 & 2.06 & ND & 2.88 & 0.21 & 4.90 & 0.00 & 3.52 \\
\hline 3.12 & 5.30 & 3.30 & 2.17 & 2.18 & 0.20 & 4.60 & 0.16 & 3.90 \\
\hline 3.86 & 5.81 & 3.60 & 2.58 & 1.82 & 0.24 & 3.70 & 0.14 & 2.90 \\
\hline 3.53 & 6.59 & 3.50 & 1.61 & 2.36 & 0.15 & 4.70 & 0.34 & 6.00 \\
\hline 3.39 & 4.86 & 3.60 & 2.70 & 1.69 & 0.20 & 3.70 & 0.26 & 2.40 \\
\hline 4.25 & 3.23 & 2.44 & ND & 2.13 & 0.19 & 5.49 & 0.06 & 3.63 \\
\hline 3.56 & 6.94 & 3.40 & 2.09 & 2.47 & 0.21 & 4.70 & 0.80 & 5.70 \\
\hline 4.02 & 2.70 & 3.70 & 2.19 & 2.31 & 0.17 & 5.40 & 0.70 & 2.20 \\
\hline 3.48 & 4.93 & 3.60 & 2.76 & 1.96 & 0.21 & 3.60 & 0.90 & 2.20 \\
\hline 3.37 & 2.61 & 3.50 & ND & 2.20 & 0.17 & 4.10 & 0.22 & 2.80 \\
\hline 3.22 & 2.74 & 2.03 & ND & 1.93 & 0.16 & 4.27 & 0.37 & 3.26 \\
\hline 3.30 & 2.56 & 3.40 & ND & 2.36 & 0.18 & 5.30 & 0.67 & 2.90 \\
\hline 3.38 & 4.69 & 2.90 & ND & 2.69 & 0.21 & 4.00 & 0.11 & 4.10 \\
\hline 3.67 & 3.21 & 3.20 & ND & 2.68 & 0.20 & 5.10 & 0.10 & 2.40 \\
\hline 4.02 & 2.96 & 1.97 & ND & 3.00 & 0.19 & ND & ND & ND \\
\hline 2.97 & 3.06 & 3.20 & 2.32 & 2.15 & 0.16 & ND & 2.49 & 3.00 \\
\hline 3.32 & 3.62 & 3.60 & 2.43 & 1.91 & 0.19 & 4.00 & 0.49 & 3.10 \\
\hline 2.81 & 4.07 & 3.50 & 2.73 & 1.75 & 0.19 & 3.00 & 0.27 & 2.10 \\
\hline 3.88 & 3.91 & 3.30 & 2.26 & 2.33 & 0.23 & 4.20 & 0.46 & 2.90 \\
\hline 3.64 & 3.56 & 2.06 & 2.06 & 2.71 & 0.22 & 4.36 & 0.00 & 2.97 \\
\hline 2.80 & 5.26 & 3.60 & 3.06 & 1.54 & 0.21 & 2.40 & 0.32 & 1.90 \\
\hline 3.19 & 3.94 & 3.40 & 2.77 & 2.02 & 0.22 & 2.70 & 0.16 & 1.80 \\
\hline 2.21 & 4.77 & 3.60 & 3.13 & 1.34 & 0.19 & 1.70 & 0.28 & 1.20 \\
\hline 3.71 & 3.90 & 2.31 & ND & 2.42 & 0.25 & 4.54 & 0.24 & 3.26 \\
\hline 4.09 & 13.10 & 2.40 & ND & 1.78 & 0.21 & 2.40 & 0.12 & 11.70 \\
\hline 2.50 & 4.25 & 3,40 & 2.91 & 1.58 & 0.22 & 2.60 & 0.82 & 1.60 \\
\hline 3.68 & 4.10 & 3.40 & 2.66 & 1.92 & 0.23 & 4.20 & 0.25 & 2.40 \\
\hline 4.04 & 4.90 & 3.50 & ND & 1.94 & 0.22 & 4.30 & 0.17 & 3.40 \\
\hline 4.10 & 4.48 & 2.75 & ND & 1.88 & 0.23 & 4.27 & 0.00 & 3.15 \\
\hline 3.48 & 4.07 & 3.40 & 2.67 & 1.80 & 0.22 & 3.30 & 0.42 & 2.10 \\
\hline 4.27 & 3.16 & 3.30 & 2.40 & 2.25 & 0.21 & 5.20 & 0.24 & 2.30 \\
\hline 3.40 & 4.25 & 3.40 & 2.71 & 1.83 & 0.20 & 3.10 & 0.56 & 2.20 \\
\hline 4.02 & 3.29 & 3.20 & 2.24 & 2.10 & 0.22 & 4.80 & 0.37 & 2.40 \\
\hline 4.46 & 3.35 & 2.15 & ND & 2.53 & 0.23 & 5.17 & 0.00 & 2.97 \\
\hline 3.62 & 4.25 & 3.30 & 2.55 & 2.17 & 0.23 & 4.20 & 0.14 & 2.70 \\
\hline 2.46 & 4.40 & 3.50 & 3.04 & 1.61 & 0.19 & 2.10 & 0.28 & 1.80 \\
\hline 3.27 & 4.12 & 3.60 & 2.94 & 1.89 & 0.22 & 3.00 & 0.15 & 1.80 \\
\hline 3.66 & 3.59 & 3.40 & 2.69 & 2.12 & 0.24 & 3.70 & 0.28 & 2.20 \\
\hline 3.36 & 3.70 & 2.60 & ND & 1.92 & 0.22 & 3.54 & 0.26 & 2.75 \\
\hline 2.36 & 4.05 & 3.60 & 3.13 & 1.58 & 0.18 & 2.00 & 0.15 & 1.50 \\
\hline 2.62 & 4.06 & 3.60 & 2.98 & 1.76 & 0.20 & 2.00 & 0.29 & 1.70 \\
\hline 10.20 & 19.80 & 1.40 & ND & 1.05 & 0.23 & 2.10 & 0.63 & 26.20 \\
\hline 3.71 & 3.73 & 3.60 & 3.02 & 1.75 & 0.20 & 3.20 & 0.17 & 1.70 \\
\hline 4.62 & 3.45 & 3.50 & 3.50 & 1.94 & 0.22 & 3.80 & 0.08 & 2.00 \\
\hline 3.76 & 3.49 & 3.50 & 2.83 & 1.71 & 0.19 & 3.50 & 0.76 & 1.50 \\
\hline 4.70 & 3.04 & 3.30 & 2.53 & 2.11 & 0.21 & 3.60 & 0.23 & 2.10 \\
\hline 4.11 & 2.68 & 3.40 & 2.44 & 2.09 & 0.18 & 3.70 & 0.40 & 1.80 \\
\hline 4.08 & 2.91 & 2.58 & ND & 2.19 & 0.19 & 3.90 & 0.78 & 3.74 \\
\hline 3.55 & 2.35 & 3.40 & 2.87 & 1.88 & 0.19 & 4.10 & 0.27 & 1.30 \\
\hline 4.55 & 3.74 & 2.61 & ND & 2.03 & 0.22 & 3.90 & 0.43 & 3.15 \\
\hline 3.69 & 3.79 & 3.30 & 2.65 & 2.21 & 0.25 & 3.00 & 0.09 & 2.20 \\
\hline 4.28 & 3.48 & 3.40 & 2.54 & 2.27 & 0.20 & 3.90 & 0.15 & 2.80 \\
\hline 4.48 & 4.40 & 2.18 & ND & 2.53 & 0.24 & 4.09 & 0.02 & 2.42 \\
\hline 4.30 & 3.38 & 3.40 & 2.69 & 2.02 & 0.19 & 3.50 & 0.09 & 2.30 \\
\hline 4.98 & 2.43 & 2.54 & ND & 2.16 & 0.23 & 3.09 & 0.00 & 18.28 \\
\hline 4.09 & 2.87 & 3.40 & 2.81 & 1.91 & 0.23 & 4.10 & 0.12 & 1.80 \\
\hline 3.79 & 3.84 & 4.20 & 3.74 & 1.64 & 0.24 & 2.60 & 0.21 & 1.10 \\
\hline 11.90 & 21.20 & 1.20 & ND & 0.55 & 0.19 & 1.50 & 0.07 & 30.50 \\
\hline 4.58 & 2.18 & 2.45 & ND & 2.26 & 0.19 & 4.99 & 0.03 & 1.76 \\
\hline 5.08 & 2.01 & 3.08 & ND & 2.33 & 0.19 & 5.17 & 0.00 & 1.80 \\
\hline 4.35 & 2.53 & 3.40 & 2.63 & 2.07 & 0.19 & 4.30 & 0.16 & 1.80 \\
\hline 11.50 & 19.50 & 1.60 & ND & 0.60 & 0.19 & 1.30 & 0.15 & 27.00 \\
\hline 10.10 & 18.00 & 1.60 & 1.48 & 0.78 & 0.31 & 1.80 & 0.14 & 24.60 \\
\hline
\end{tabular}


Table 1 (continued).

\begin{tabular}{|c|c|c|c|c|c|c|c|c|}
\hline & & & & Udepth & Ldepth & Depth & & \\
\hline Leg & Hole & Core & Section & $(\mathrm{cm})$ & $(\mathrm{cm})$ & (mbsf) & Lithology & Induration \\
\hline 139 & $857 \mathrm{C}$ & $09 \mathrm{R}$ & 1 & 8 & 9 & 114.58 & SLST & indurated \\
\hline 139 & $857 \mathrm{C}$ & 09R & 1 & 27 & 30 & 114.77 & SLCY & indurated \\
\hline 139 & $857 \mathrm{C}$ & $09 \mathrm{R}$ & 1 & 89 & 91 & 115.39 & SILT & moderate \\
\hline 139 & $857 C$ & $10 \mathrm{R}$ & 1 & 65 & 67 & 124.75 & SLCY & moderate \\
\hline 139 & $857 \mathrm{C}$ & $11 \mathrm{R}$ & 1 & 124 & 126 & 135.04 & SILT & indurated \\
\hline 139 & $857 \mathrm{C}$ & $12 \mathrm{R}$ & 1 & 9 & 10 & 143.59 & SILT & indurated \\
\hline 139 & $857 \mathrm{C}$ & $12 \mathrm{R}$ & 1 & 40 & 43 & 143.90 & SILT & moderate \\
\hline 139 & $857 \mathrm{C}$ & $12 \mathrm{R}$ & 1 & 47 & 48 & 143.97 & SILT & indurated \\
\hline 139 & $857 \mathrm{C}$ & $12 \mathrm{R}$ & 1 & 80 & 83 & 144.30 & SLCY & indurated \\
\hline 139 & $857 \mathrm{C}$ & $12 \mathrm{R}$ & 1 & 126 & 127 & 144.76 & SLST & indurated \\
\hline 139 & $857 \mathrm{C}$ & $13 R$ & 1 & 6 & 8 & 153.16 & SLST & indurated \\
\hline 139 & $857 C$ & $13 R$ & 1 & 52 & 55 & 153.62 & SLCY & moderate \\
\hline 139 & $857 \mathrm{C}$ & $13 R$ & 2 & 48 & 51 & 155.08 & SLCY & moderate \\
\hline 139 & $857 C$ & $13 R$ & 3 & 52 & 54 & 156.62 & SILT & moderate \\
\hline 139 & $857 \mathrm{C}$ & $14 \mathrm{R}$ & 2 & 27 & 31 & 164.57 & SLCY & moderate \\
\hline 139 & $857 C$ & $14 \mathrm{R}$ & 2 & 50 & 54 & 164.80 & SLCY & moderate \\
\hline 139 & $857 \mathrm{C}$ & $15 R$ & 1 & 93 & 95 & 173.43 & SLCY & moderate \\
\hline 139 & $857 \mathrm{C}$ & $15 R$ & 1 & 147 & 149 & 173.97 & SLCY & moderate \\
\hline 139 & $857 \mathrm{C}$ & $15 R$ & 3 & 142 & 144 & 176.92 & SLCY & moderate \\
\hline 139 & $857 \mathrm{C}$ & $16 \mathrm{R}$ & 1 & 15 & 17 & 182.35 & SILT & moderate \\
\hline 139 & $857 \mathrm{C}$ & $17 \mathrm{R}$ & 1 & 82 & 86 & 192.72 & SILT & moderate \\
\hline 139 & $857 \mathrm{C}$ & $17 \mathrm{R}$ & 2 & 61 & 65 & 194.01 & SLCY & moderate \\
\hline 139 & $857 C$ & $18 \mathrm{R}$ & 1 & 76 & 80 & 202.36 & SLCY & moderate \\
\hline 139 & $857 C$ & $18 \mathrm{R}$ & 2 & 30 & 34 & 203.40 & SLCY & moderate \\
\hline 139 & $857 C$ & $19 \mathrm{R}$ & 2 & 57 & 61 & 213.37 & SLCY & moderate \\
\hline 139 & $857 \mathrm{C}$ & $19 \mathrm{R}$ & 2 & 78 & 82 & 213.58 & SILT & indurated \\
\hline 139 & $857 C$ & $21 \mathrm{R}$ & 1 & 24 & 26 & 230.84 & SLCS & indurated \\
\hline 139 & $857 C$ & $21 \mathrm{R}$ & 1 & 129 & 131 & 231.89 & SILT & indurated \\
\hline 139 & $857 C$ & $21 \mathrm{R}$ & 3 & 27 & 29 & 233.87 & SLCS & indurated \\
\hline 139 & $857 \mathrm{C}$ & $22 \mathrm{R}$ & 1 & 28 & 32 & 240.58 & SLCS & indurated \\
\hline 139 & $857 \mathrm{C}$ & $22 \mathrm{R}$ & 1 & 124 & 127 & 241.54 & SLCY & indurated \\
\hline 139 & $857 \mathrm{C}$ & $22 \mathrm{R}$ & 0 & 1 & 5 & 242.01 & SLCS & indurated \\
\hline 139 & $857 \mathrm{C}$ & $24 \mathrm{R}$ & 1 & 31 & 35 & 259.51 & SLCS & indurated \\
\hline 139 & $857 \mathrm{C}$ & $24 \mathrm{R}$ & 1 & 57 & 59 & 259.77 & SLCY & indurated \\
\hline 139 & $857 \mathrm{C}$ & $24 \mathrm{R}$ & 2 & 5 & 7 & 260.75 & SLCY & indurated \\
\hline 139 & $857 \mathrm{C}$ & $24 \mathrm{R}$ & 2 & 33 & 37 & 261.03 & SLCY & indurated \\
\hline 139 & $857 \mathrm{C}$ & $25 \mathrm{R}$ & 1 & 6 & 8 & 268.86 & SLCS & indurated \\
\hline 139 & $857 \mathrm{C}$ & $25 R$ & 1 & 51 & 54 & 269.31 & SLCY & indurated \\
\hline 139 & $857 \mathrm{C}$ & 26R & 1 & 18 & 20 & 274.68 & SLCS & indurated \\
\hline 139 & $857 C$ & $26 \mathrm{R}$ & 1 & 66 & 68 & 275.16 & SLCY & indurated \\
\hline 139 & $857 \mathrm{C}$ & $26 \mathrm{R}$ & 0 & 1 & 3 & 276.24 & SNST & indurated \\
\hline 139 & $857 \mathrm{C}$ & $27 \mathrm{R}$ & 1 & 116 & 120 & 285.26 & SLCS & indurated \\
\hline 139 & $857 \mathrm{C}$ & $27 \mathrm{R}$ & 2 & 87 & 90 & 286.47 & SLCY & indurated \\
\hline 139 & $857 \mathrm{C}$ & $28 \mathrm{R}$ & 2 & 119 & 122 & 296.49 & SLCS & indurated \\
\hline 139 & $857 \mathrm{C}$ & $28 \mathrm{R}$ & 3 & 27 & 29 & 297.07 & SLCY & indurated \\
\hline 139 & $857 \mathrm{C}$ & $29 \mathrm{R}$ & 1 & 58 & 61 & 303.98 & SILT & indurated \\
\hline 139 & $857 \mathrm{C}$ & $28 \mathrm{R}$ & $\mathrm{CC}$ & 1 & 4 & 313.00 & SNSL & indurated \\
\hline 139 & $857 \mathrm{C}$ & $30 \mathrm{R}$ & 1 & 116 & 120 & 314.26 & SSSL & indurated \\
\hline 139 & $857 \mathrm{C}$ & $30 \mathrm{R}$ & 2 & 74 & 77 & 315.34 & SILT & indurated \\
\hline 139 & $857 \mathrm{C}$ & 30R & 3 & 30 & 33 & 316.40 & SLCS & indurated \\
\hline 139 & $857 \mathrm{C}$ & $31 \mathrm{R}$ & 1 & 121 & 123 & 323.91 & SLCS & indurated \\
\hline 139 & $857 \mathrm{C}$ & $31 \mathrm{R}$ & 2 & 15 & 17 & 324.35 & SLCS & indurated \\
\hline 139 & $857 \mathrm{C}$ & $31 \mathrm{R}$ & 2 & 102 & 105 & 325.22 & SLCS & indurated \\
\hline 139 & $857 \mathrm{C}$ & $32 \mathrm{R}$ & 1 & 34 & 37 & 327.94 & SLCS & indurated \\
\hline 139 & $857 \mathrm{C}$ & $33 R$ & 1 & 56 & 59 & 332.96 & SLCS & indurated \\
\hline 139 & $857 \mathrm{C}$ & $33 R$ & 2 & 71 & 73 & 334.61 & SLCS & indurated \\
\hline 139 & $857 \mathrm{C}$ & $33 R$ & 3 & 65 & 68 & 336.05 & SLCS & indurated \\
\hline 139 & $857 \mathrm{C}$ & $34 \mathrm{R}$ & 1 & 120 & 122 & 337.70 & SLST & indurated \\
\hline 139 & $857 \mathrm{C}$ & $34 \mathrm{R}$ & 3 & 44 & 47 & 339.94 & SLCS & indurated \\
\hline 139 & $857 \mathrm{C}$ & $35 \mathrm{R}$ & 1 & 34 & 36 & 341.64 & SLST & indurated \\
\hline 139 & $857 \mathrm{C}$ & $35 R$ & 1 & 124 & 127 & 342.54 & SLST & indurated \\
\hline 139 & $857 \mathrm{C}$ & $35 R$ & 5 & 31 & 33 & 344.50 & SLCS & indurated \\
\hline 139 & $857 \mathrm{C}$ & $36 \mathrm{R}$ & 1 & 29 & 32 & 346.39 & SLCS & indurated \\
\hline 139 & $857 \mathrm{C}$ & $36 \mathrm{R}$ & 1 & 79 & 81 & 348.89 & SLCS & indurated \\
\hline 139 & $857 \mathrm{C}$ & $36 \mathrm{R}$ & 3 & 58 & 61 & 349.68 & SLCS & indurated \\
\hline 139 & $857 \mathrm{C}$ & 37R & 1 & 115 & 119 & 351.95 & SLCS & indurated \\
\hline 139 & $857 \mathrm{C}$ & $37 \mathrm{R}$ & 2 & 115 & 119 & 353.45 & SLCS & indurated \\
\hline 139 & $857 C$ & $37 R$ & 2 & 126 & 128 & 353.56 & SLST & indurated \\
\hline 139 & $857 \mathrm{C}$ & $38 \mathrm{R}$ & 2 & 50 & 53 & 357.80 & SLCS & indurated \\
\hline 139 & $857 \mathrm{C}$ & $38 \mathrm{R}$ & 2 & 57 & 61 & 357.87 & SLCS & indurated \\
\hline 139 & $857 \mathrm{C}$ & $39 \mathrm{R}$ & 1 & 66 & 68 & 361.06 & SLCS & indurated \\
\hline 139 & $857 \mathrm{C}$ & $39 \mathrm{R}$ & 2 & 48 & 50 & 362.38 & SLCS & indurated \\
\hline 139 & $857 \mathrm{C}$ & $39 \mathrm{R}$ & 3 & 62 & 65 & 364.02 & SLST & indurated \\
\hline 139 & $857 \mathrm{C}$ & $40 \mathrm{R}$ & 2 & 30 & 35 & 367.20 & SLCS & indurated \\
\hline 139 & $857 \mathrm{C}$ & $41 \mathrm{R}$ & 2 & 89 & 91 & 377.29 & SLCS & indurated \\
\hline 139 & $857 \mathrm{C}$ & $41 \mathrm{R}$ & 2 & 122 & 126 & 377.62 & SLCS & indurated \\
\hline 139 & $857 \mathrm{C}$ & $42 R$ & 1 & 82 & 84 & 380.52 & SLCS & indurated \\
\hline 139 & $857 \mathrm{C}$ & $42 \mathrm{R}$ & 2 & 37 & 41 & 381.57 & SLST & indurated \\
\hline 139 & $857 \mathrm{C}$ & $43 R$ & 1 & 130 & 134 & 386.00 & SLCS & indurated \\
\hline 139 & $857 \mathrm{C}$ & $43 R$ & 2 & 9 & 12 & 386.29 & SLCS & indurated \\
\hline 139 & $857 \mathrm{C}$ & $43 R$ & 3 & 77 & 81 & 388.47 & SLCS & indurated \\
\hline 139 & $857 \mathrm{C}$ & $44 \mathrm{R}$ & 1 & 137 & 140 & 391.07 & SLST & indurated \\
\hline 139 & $857 \mathrm{C}$ & $44 R$ & 0 & 12 & 16 & 392.76 & SLCS & indurated \\
\hline 139 & $857 \mathrm{C}$ & $45 R$ & 1 & 134 & 138 & 395.64 & SLST & indurated \\
\hline 139 & $857 C$ & $45 R$ & 2 & 42 & 44 & 396.22 & SLCS & indurated \\
\hline 139 & $857 \mathrm{C}$ & $45 \mathrm{R}$ & 2 & 79 & 81 & 396.57 & SLCS & indurated \\
\hline 139 & $857 \mathrm{C}$ & $45 \mathrm{R}$ & 2 & 81 & 83 & 396.59 & SLCS & indurated \\
\hline 139 & $857 \mathrm{C}$ & $46 \mathrm{R}$ & 1 & 71 & 75 & 399.71 & SLCS & indurated \\
\hline
\end{tabular}


Table 1 (continued).

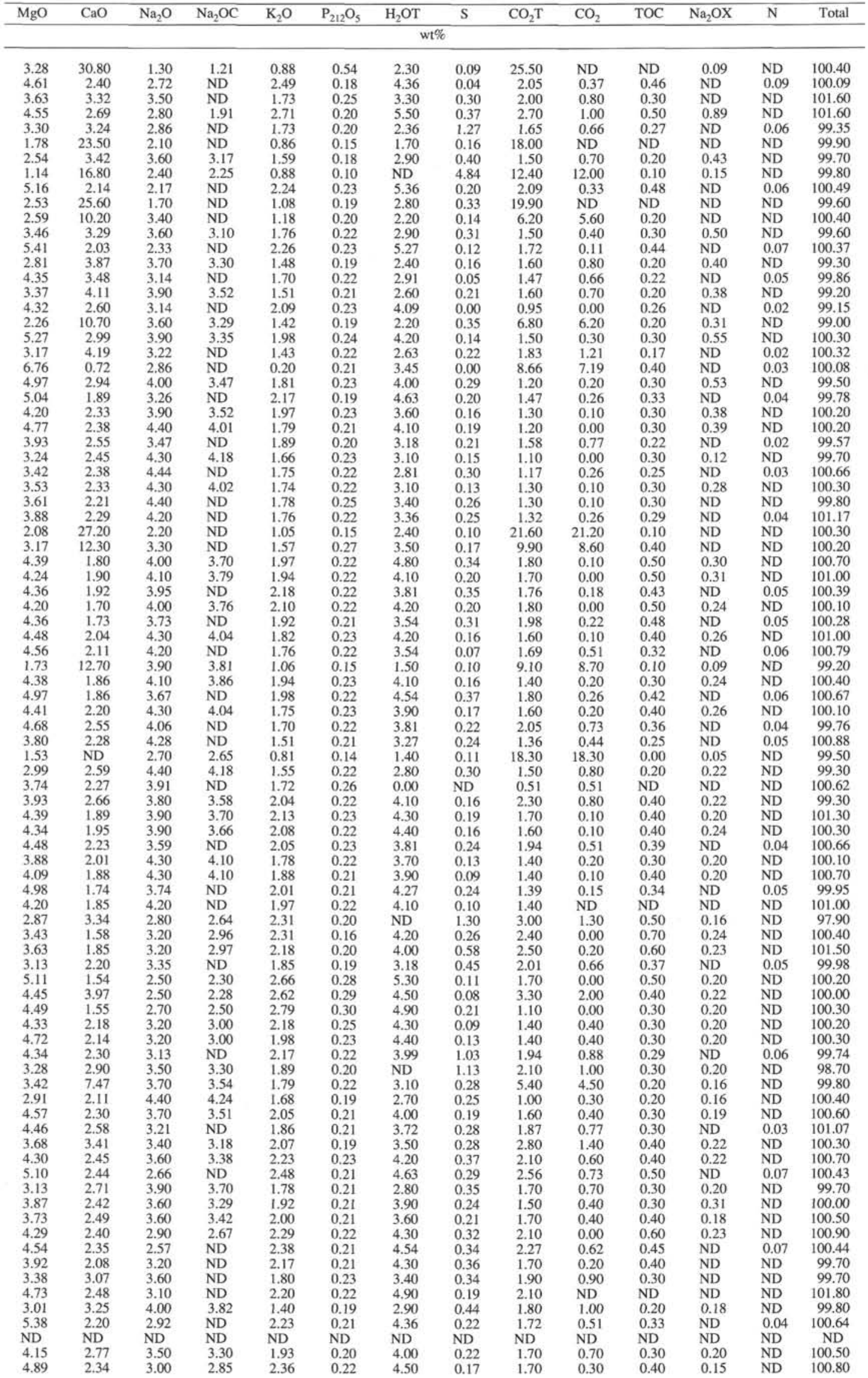


Table 1 (continued).

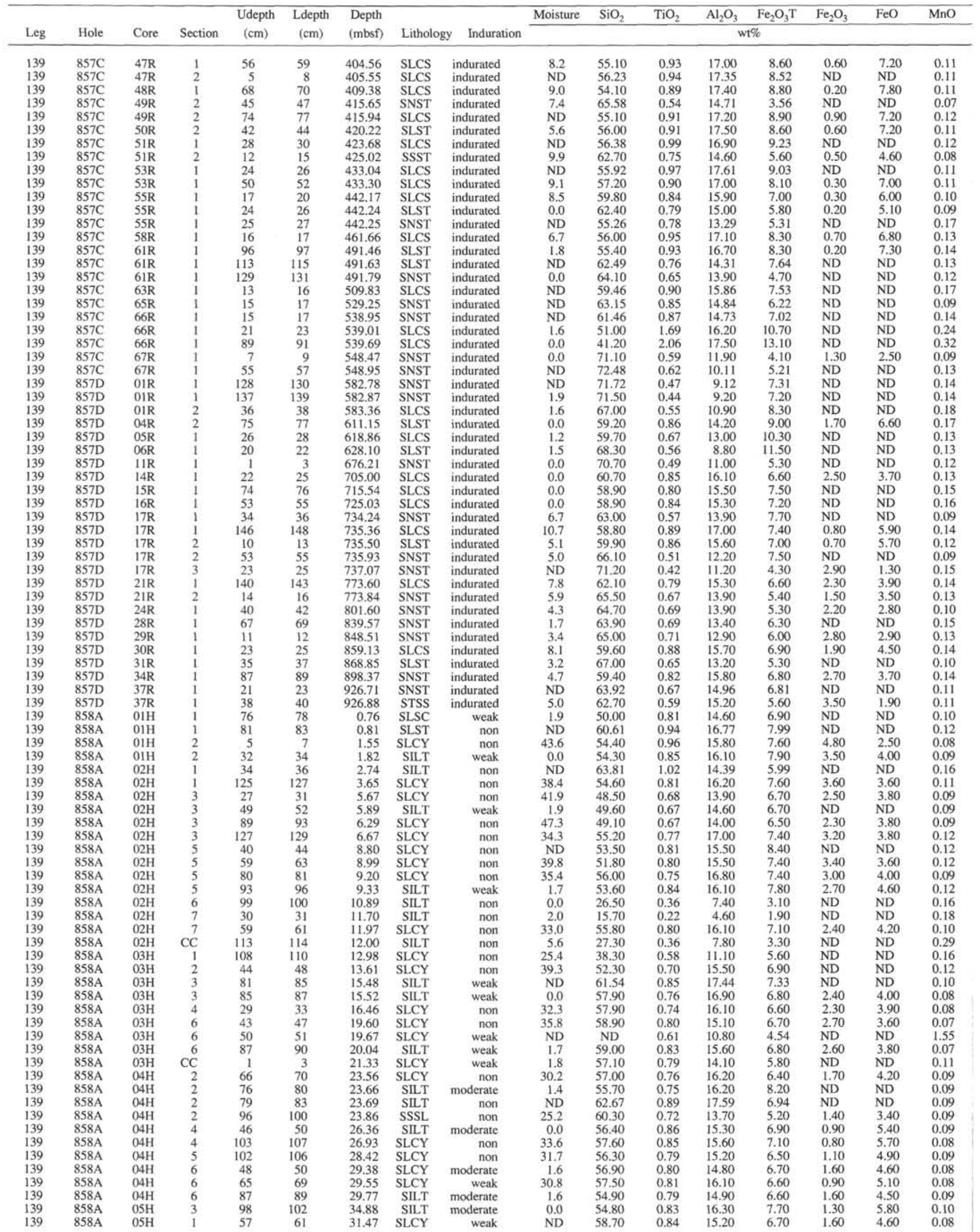


Table 1 (continued).

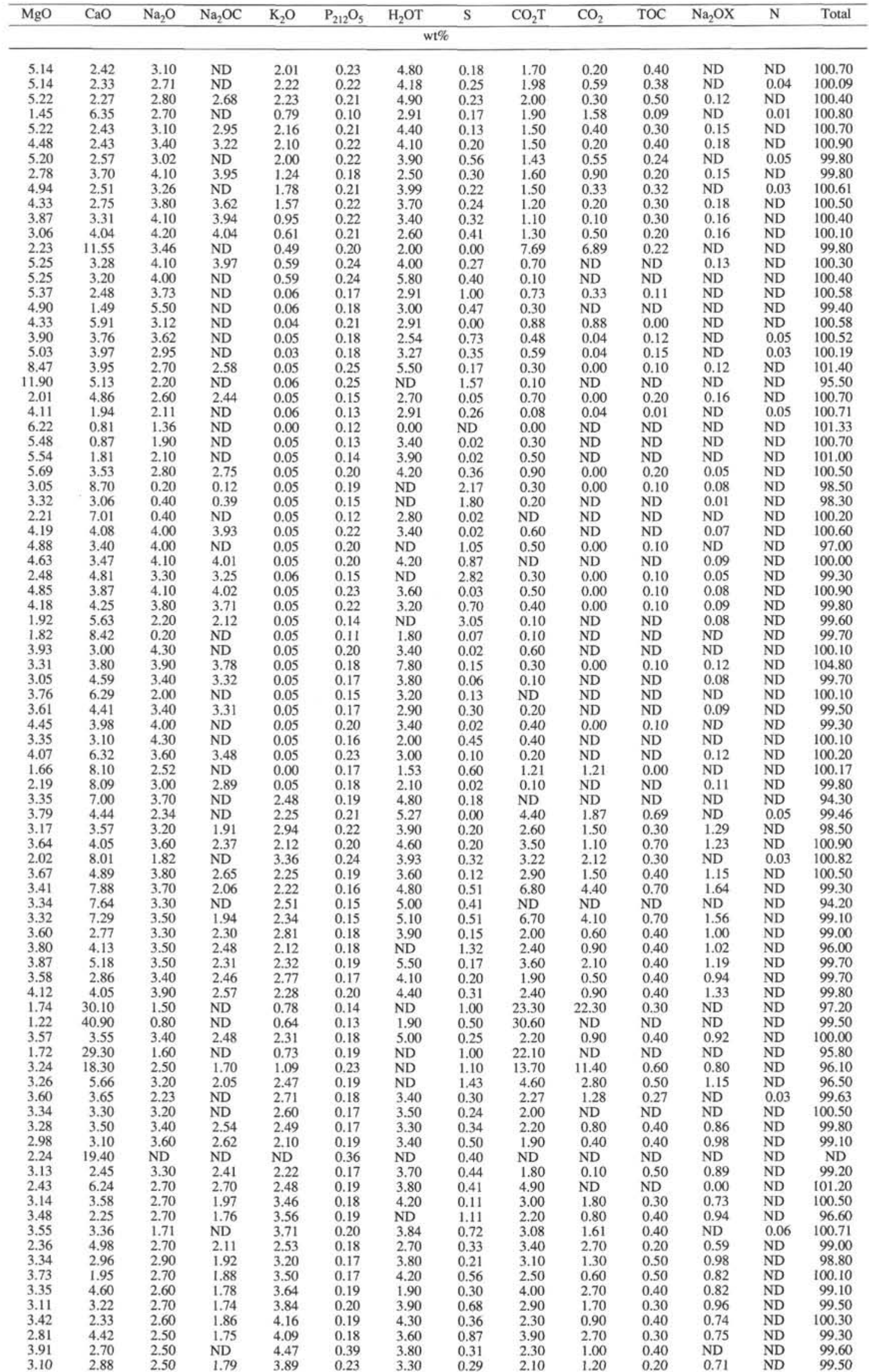


Table 1 (continued).

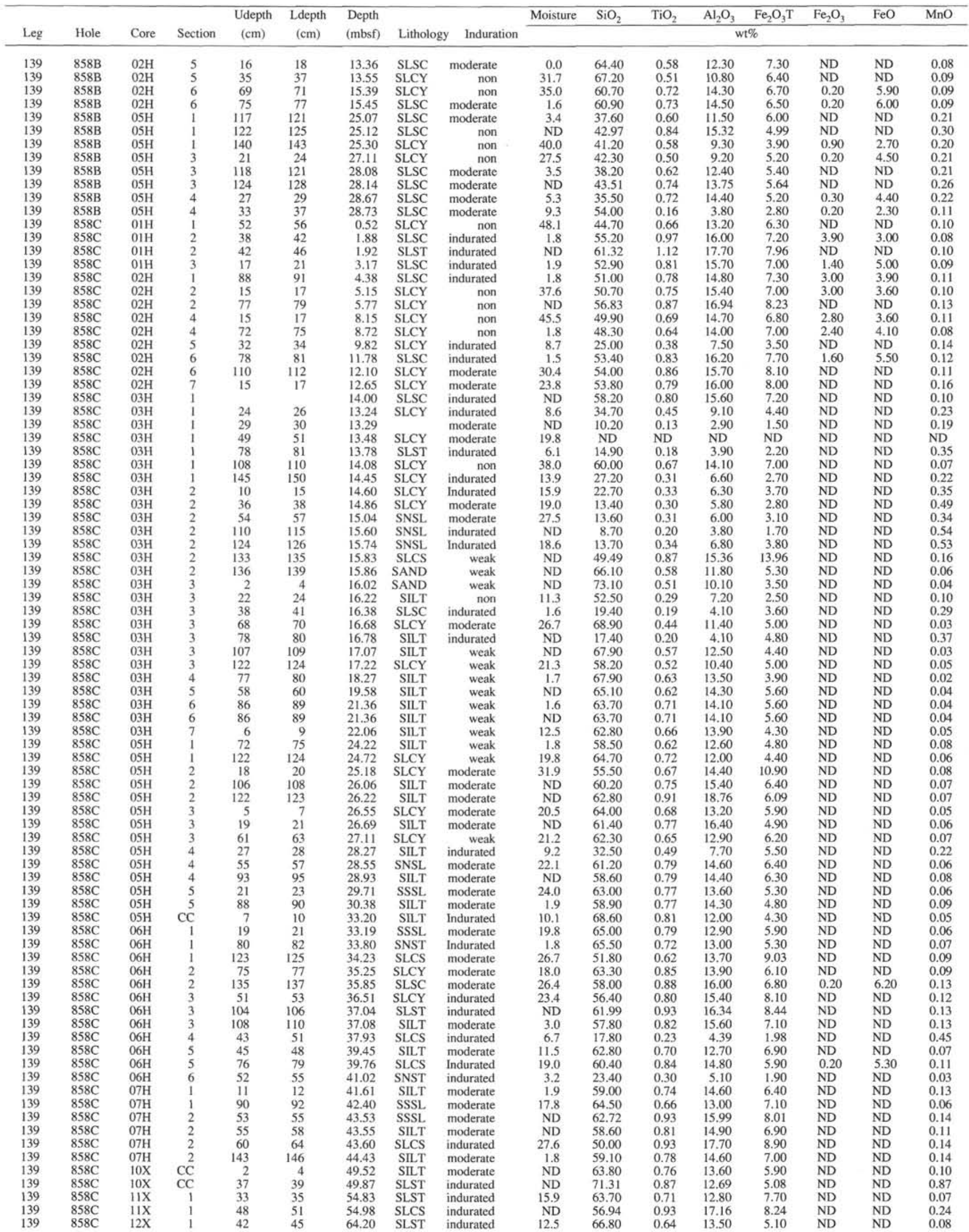


Table 1 (continued).

\begin{tabular}{|c|c|c|c|c|c|c|c|c|}
\hline $\mathrm{MgO}$ & $\mathrm{CaO}$ & $\mathrm{Na}_{2} \mathrm{O}$ & $\mathrm{Na}_{2} \mathrm{OC}$ & $\mathrm{K}_{2} \mathrm{O}$ & $\mathrm{P}_{212} \mathrm{O}_{5}$ & $\mathrm{H}_{2} \mathrm{OT}$ & $\mathrm{S}$ & $\mathrm{CO}_{2} \mathrm{~T}$ \\
\hline & & & & & & & & \\
\hline 4.53 & 0.94 & 2.30 & ND & 1.31 & 0.15 & ND & 2.30 & 0.60 \\
\hline 4.27 & 1.90 & 1.90 & 1.10 & 1.34 & 0.13 & ND & 1.71 & 1.40 \\
\hline 6.23 & 0.77 & 2.20 & 1.38 & 1.77 & 0.18 & 5,10 & 0.72 & 0.70 \\
\hline 6.48 & 0.74 & 2.30 & ND & 1.68 & 0.18 & 5.30 & 0.58 & 0.80 \\
\hline 26.90 & 2.22 & 1.00 & 0.10 & 0.22 & 0.04 & ND & 1.93 & 1.30 \\
\hline 34.18 & 1.57 & 0.01 & ND & 0.01 & 0.01 & 12.51 & 0.56 & 0.92 \\
\hline 28.20 & 1.91 & 1.30 & ND & 0.11 & 0.07 & 10.30 & 0.05 & 1.00 \\
\hline 28.10 & 1.34 & 0.80 & ND & 0.07 & 0.03 & 10.90 & 0.85 & 0.90 \\
\hline 27.90 & 1.44 & 0.80 & ND & 0.20 & 0.03 & ND & 1.40 & 0.90 \\
\hline 34.08 & 1.66 & 0.13 & ND & 0.03 & 0.02 & 12.87 & 0.88 & 0.62 \\
\hline 28.20 & 1.45 & 0.90 & 0.20 & 0.08 & 0.04 & 12.20 & 0.76 & 1.00 \\
\hline 29.60 & 0.79 & 0.50 & 0.14 & 0.05 & 0.06 & 8.60 & 0.17 & 0.30 \\
\hline 3.35 & 10.40 & 3.40 & 1.78 & 2.04 & 0.16 & 5.20 & 0.93 & 9.50 \\
\hline 3.14 & 3.48 & 3.20 & ND & 3.01 & 0.23 & 5.10 & 0.15 & 2.30 \\
\hline 3.46 & 3.76 & 1.80 & ND & 3.28 & 0.24 & 4.47 & 0.24 & 2.75 \\
\hline 3.29 & 4.74 & 3.40 & ND & 2.66 & 0.18 & 5.30 & 0.60 & 3.80 \\
\hline 3.57 & 7.06 & 3.40 & 2.63 & 1.99 & 0.20 & 4.60 & 0.27 & 4.80 \\
\hline 3.57 & 6.22 & 3.40 & 2.15 & 2.36 & 0.19 & 4.80 & 0.39 & 4.60 \\
\hline 3.98 & 7.86 & 2.65 & ND & 2.45 & 0.20 & 4.20 & 0.35 & 6.04 \\
\hline 3.70 & 7.32 & 3.50 & ND & 2.40 & 0.15 & 5.00 & 0.30 & 5.90 \\
\hline 3.58 & 7.52 & 3.60 & 2.02 & 2.51 & 0.14 & 5.20 & 0.60 & 6.00 \\
\hline 2.05 & 29.00 & 1.40 & 0.96 & 0.74 & 0.22 & ND & 1.23 & 22.50 \\
\hline 4.27 & 4.46 & 2.80 & 2.00 & 2.82 & 0.21 & 4.70 & 0.46 & 3.50 \\
\hline 3.94 & 3.47 & 2.90 & 2.00 & 2.84 & 0.22 & ND & 1.60 & 2.50 \\
\hline 3.37 & 3.79 & 2.90 & 2.20 & 3.06 & 0.20 & ND & 2.63 & 2.80 \\
\hline 2.21 & 2.03 & 3.50 & 2.46 & 3.25 & 0.17 & ND & 3.70 & 1.20 \\
\hline 1.24 & 23.80 & 1.90 & 1.44 & 1.30 & 0.20 & ND & 2.90 & 17.60 \\
\hline 1.10 & 44.40 & 0.50 & ND & 0.34 & 0.13 & ND & 1.02 & 34.50 \\
\hline ND & ND & ND & 0.00 & ND & ND & ND & ND & ND \\
\hline 0.91 & 40.90 & 0.60 & 0.45 & 0.57 & 0.26 & ND & 1.67 & 32.70 \\
\hline 1.50 & 1.14 & 3.00 & 1.92 & 3.74 & 0.13 & ND & 4.71 & 1.40 \\
\hline 0.98 & 31.60 & 1.20 & 0.76 & 1.04 & 0.16 & ND & 1.90 & 24.10 \\
\hline 1.11 & 33.00 & 1.20 & 0.84 & 1.04 & 0.29 & ND & 2.70 & 25.90 \\
\hline 1.35 & 40.40 & 0.70 & 0.19 & 0.72 & 0.20 & ND & 1.95 & 31.00 \\
\hline 1.60 & 38.00 & 0.80 & 0.25 & 0.65 & 0.17 & ND & 2.25 & 30.10 \\
\hline 1.02 & 44.50 & 0.50 & 0.00 & 0.44 & 0.10 & ND & 1.34 & 35.00 \\
\hline 1.37 & 37.40 & 0.90 & 0.17 & 0.79 & 0.14 & ND & 2.70 & 28.60 \\
\hline 0.92 & 8.14 & 1.12 & ND & 5.75 & 0.24 & 2.06 & 6.55 & 6.89 \\
\hline 0.61 & 1.95 & 1.80 & 1.25 & 5.18 & 0.15 & ND & 4.03 & 2.00 \\
\hline 0.43 & 2.23 & 1.70 & ND & 3.72 & 0.13 & ND & 2.55 & 1.20 \\
\hline 0.36 & 16.70 & 1.10 & 0.63 & 2.40 & 0.07 & ND & 1.96 & 12.60 \\
\hline 0.37 & 37.20 & 0.60 & 0.29 & 0.93 & 0.13 & ND & 2.93 & 29.00 \\
\hline 0.55 & 0.93 & 1.70 & 1.03 & 4.91 & 0.12 & ND & 3.76 & 0.80 \\
\hline 0.50 & 36.90 & 0.70 & 0.50 & 0.92 & 0.13 & ND & 4.04 & 29.10 \\
\hline 0.62 & 1.47 & 2.00 & ND & 4.92 & 0.14 & ND & 3.04 & 1.40 \\
\hline 0.52 & 7.86 & 1.90 & 1.28 & 3.73 & 0.12 & ND & 3.90 & 5.70 \\
\hline 0.67 & 2.05 & 3.30 & 2.59 & 3.41 & 0.17 & ND & 2.50 & 0.70 \\
\hline 1.11 & 1.08 & 2.50 & 1.95 & 4.02 & 0.15 & ND & 3.20 & 0.80 \\
\hline 1.18 & 1.30 & 3.00 & 2.45 & 4.08 & 0.17 & ND & 3.10 & 1.00 \\
\hline 1.18 & 1.30 & 3.00 & 2.45 & 4.08 & 0.17 & ND & 3.10 & 1.00 \\
\hline 1.16 & 3.13 & 3.20 & 2.63 & 3.76 & 0.16 & ND & 2.10 & 2.10 \\
\hline 1.64 & 7.00 & 2.10 & 1.49 & 3.42 & 0.16 & ND & 1.80 & 5.20 \\
\hline 1.67 & 5.22 & 2.60 & 2.13 & 2.01 & 0.19 & ND & 1.44 & 3.40 \\
\hline 2.68 & 2.61 & 3.19 & 2.35 & 2.08 & 0.19 & ND & 5.60 & 1.80 \\
\hline 2.55 & 2.57 & 3.00 & ND & 3.00 & 0.19 & ND & 2.11 & 1.80 \\
\hline 3.63 & 1.51 & 1.93 & ND & 4.27 & 0.20 & 3.13 & 1.23 & 1.65 \\
\hline 1.93 & 2.74 & 2.70 & 2.16 & 2.41 & 0.18 & ND & 2.42 & 1.50 \\
\hline 3.25 & 0.93 & 2.90 & 1.75 & 3.66 & 0.19 & 3.60 & 0.51 & 1.20 \\
\hline 2.82 & 3.59 & 2.20 & 1.59 & 2.64 & 0.17 & ND & 2.50 & 2.70 \\
\hline 1.57 & 25.30 & 1.40 & ND & 1.28 & 0.12 & ND & 3.00 & 19.90 \\
\hline 2.44 & 1.49 & 2.10 & 1.49 & 4.86 & 0.17 & ND & 2.80 & 1.60 \\
\hline 3.00 & 2.74 & 2.50 & 1.48 & 4.25 & 0.17 & ND & 2.34 & 2.60 \\
\hline 2.96 & 1.54 & 2.10 & 1.49 & 4.17 & 0.18 & ND & 2.25 & 1.20 \\
\hline 4.49 & 2.76 & 2.10 & 1.14 & 3.85 & 0.18 & ND & 1.22 & 2.80 \\
\hline 2.51 & 1.02 & 2.30 & 1.77 & 3.93 & 0.21 & ND & 1.70 & 0.70 \\
\hline 3.32 & 1.39 & 3.10 & 2.56 & 2.45 & 0.20 & ND & 2.10 & 0.30 \\
\hline 3.99 & 1.07 & 3.10 & 2.40 & 2.28 & 0.19 & ND & 1.16 & 0.40 \\
\hline 4.54 & 4.77 & 2.37 & 1.70 & 2.84 & 0.18 & ND & 5.90 & 0.70 \\
\hline 4.23 & 1.07 & 3.20 & 2.62 & 2.35 & 0.23 & ND & 1.40 & 0.50 \\
\hline 6.68 & 0.90 & 3.30 & 2.67 & 1.41 & 0.24 & 5.10 & 0.44 & 0.60 \\
\hline 6.61 & 0.81 & 3.10 & 2.47 & 1.87 & 0.22 & ND & 2.12 & 0.90 \\
\hline 6.79 & 0.75 & 2.36 & ND & 2.16 & 0.22 & 4.38 & 1.36 & 0.81 \\
\hline 6.27 & 0.78 & 3.40 & 2.59 & 1.68 & 0.22 & ND & 1.04 & 0.70 \\
\hline 10.00 & 23.70 & 0.71 & 0.48 & 0.40 & 0.11 & ND & 8.40 & 15.20 \\
\hline 3.67 & 1.54 & 3.10 & 2.63 & 2.21 & 0.18 & ND & 3.00 & 0.40 \\
\hline 5.97 & 0.98 & 3.40 & 2.47 & 1.47 & 0.22 & 4.60 & 0.44 & 0.50 \\
\hline 2.20 & 26.10 & 1.20 & 1.13 & 0.51 & 0.09 & ND & 15.00 & 0.20 \\
\hline 7.47 & 0.66 & 3.50 & 2.61 & 1.07 & 0.24 & 4.80 & 0.90 & 0.80 \\
\hline 3.32 & 0.65 & 2.50 & 2.10 & 2.44 & 0.17 & ND & 3.55 & 0.40 \\
\hline 7.59 & 0.66 & 2.90 & ND & 0.83 & 0.24 & 4.38 & 1.95 & 0.84 \\
\hline 6.31 & 0.63 & 3.70 & 3.00 & 0.90 & 0.22 & ND & 1.36 & 0.80 \\
\hline 7.11 & 0.82 & 3.90 & 3.27 & 2.76 & 0.27 & ND & 2.21 & 1.00 \\
\hline 7.13 & 0.66 & 4.10 & ND & 0.56 & 0.20 & 4.50 & 0.81 & 0.90 \\
\hline 4.84 & 0.99 & 4.10 & 3.60 & 0.24 & 0.20 & ND & 1.03 & 0.60 \\
\hline 3.49 & 1.61 & 2.95 & ND & 1.41 & 0.18 & 2.32 & 1.53 & 0.29 \\
\hline 3.88 & 0.85 & 3.40 & 3.02 & 0.67 & 0.17 & ND & 3.42 & 0.50 \\
\hline 4.24 & 6.64 & 2.93 & ND & 2.25 & 0.23 & 4.47 & 1.34 & 0.77 \\
\hline 4.13 & 0.82 & 2.80 & 2.45 & 0.76 & 0.15 & ND & 1.60 & 0.30 \\
\hline
\end{tabular}


Table 1 (continued).

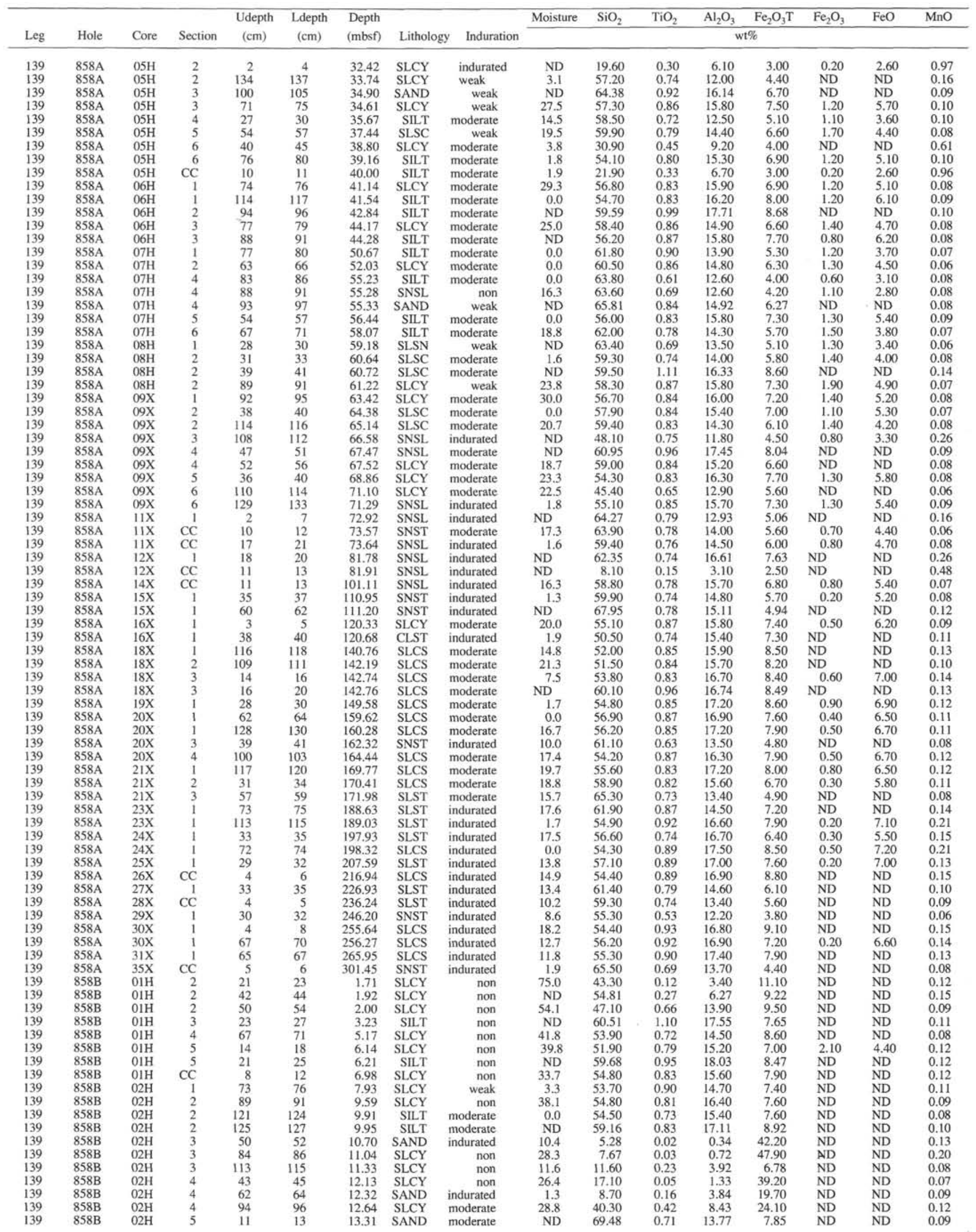


Table 1 (continued).

\begin{tabular}{|c|c|c|c|c|c|c|c|c|}
\hline $\mathrm{MgO}$ & $\mathrm{CaO}$ & $\mathrm{Na}_{2} \mathrm{O}$ & $\mathrm{Na}_{2} \mathrm{OC}$ & $\mathrm{K}_{2} \mathrm{O}$ & $\mathrm{P}_{212} \mathrm{O}_{5}$ & $\mathrm{H}_{2} \mathrm{OT}$ & $S$ & $\mathrm{CO}_{2} \mathrm{~T}$ \\
\hline & & & & & & & & \\
\hline 1.53 & 35.80 & 0.80 & ND & 1.57 & 0.61 & 1.70 & 0.04 & 27.80 \\
\hline 1.67 & ND & 2.50 & ND & 2.52 & 0.20 & 1.90 & 0.65 & ND \\
\hline 3.17 & 3.37 & 1.93 & ND & 4.26 & 0.32 & 3.22 & 0.30 & 2.56 \\
\hline 3.65 & 2.46 & 2.60 & 1.86 & 3.98 & 0.22 & 4.10 & 0.43 & 2.00 \\
\hline 1.96 & 7.56 & 2.40 & 2.01 & 3.00 & 0.18 & 2.20 & 0.80 & 5.30 \\
\hline 2.97 & 3.40 & 2.40 & 1.87 & 3.65 & 0.20 & 2.90 & 0.51 & 2.40 \\
\hline 2.05 & 26.00 & 0.90 & ND & 2.63 & 0.19 & 2.30 & 0.10 & 21.00 \\
\hline 3.44 & 4.41 & 2.60 & ND & 4.42 & 0.28 & 3.30 & 0.30 & 3.70 \\
\hline 1.56 & 33.90 & 0.70 & ND & 1.82 & 0.17 & 1.80 & 0.07 & 27.30 \\
\hline 3.55 & 2.65 & 2.30 & 1.55 & 4.27 & 0.22 & 4.30 & 0.15 & 2.30 \\
\hline 4.11 & 3.28 & 2.50 & ND & 4.14 & 0.26 & 4.00 & 0.22 & 3.20 \\
\hline 4.65 & 2.33 & 1.44 & ND & 4.39 & 0.23 & 3.40 & 1.30 & 2.45 \\
\hline 3.16 & 2.78 & 2.40 & 1.67 & 3.80 & 0.20 & 3.70 & 0.27 & 2.40 \\
\hline 3.65 & 2.42 & 2.30 & ND & 4.11 & 0.21 & 3.70 & 0.60 & 2.60 \\
\hline 2.35 & 3.50 & 2.40 & 1.83 & 3.59 & 0.20 & 3.00 & 0.18 & 2.60 \\
\hline 3.01 & 1.98 & 2.10 & 1.44 & 3.89 & 0.20 & 3.50 & 0.26 & 1.80 \\
\hline 1.75 & 5.19 & 2.60 & ND & 3.17 & 0.15 & 2.20 & 0.19 & 3.80 \\
\hline 1.71 & 5.23 & 2.60 & 2.20 & 3.08 & 0.16 & 2.00 & 0.23 & 3.50 \\
\hline 3.02 & 3.45 & 1.62 & ND & 3.66 & 0.19 & 3.49 & 0.00 & 2.49 \\
\hline 4.11 & 2.83 & 2.30 & ND & 3.85 & 0.24 & 4.20 & 0.15 & 2.70 \\
\hline 2.72 & 3.09 & 2.30 & 1.81 & 3.59 & 0.20 & 2.80 & 0.12 & 2.30 \\
\hline 2.22 & 3.57 & 2.50 & 2.04 & 3.27 & 0.17 & 2.80 & 0.16 & 2.30 \\
\hline 2.76 & 4.46 & 2.60 & ND & 3.30 & 0.20 & 2.90 & 0.20 & 3.10 \\
\hline 4.37 & 6.05 & 2.53 & ND & 2.00 & 0.26 & 2.50 & 0.00 & 12.49 \\
\hline 3.98 & 2.39 & 2.30 & 1.61 & 3.75 & 0.24 & 3.70 & 0.14 & 1.90 \\
\hline 4.22 & 2.58 & 2.10 & 1.26 & 3.99 & 0.27 & 4.40 & 0.21 & 2.40 \\
\hline 3.77 & 2.64 & 2.60 & 1.76 & 3.53 & 0.23 & 4.10 & 0.18 & 2.40 \\
\hline 3.22 & 4.12 & 2.20 & 1.67 & 3.65 & 0.24 & 3.80 & 0.19 & 3.20 \\
\hline 2.40 & 11.90 & 1.70 & ND & 2.79 & 0.23 & 7.50 & 0.20 & 9.20 \\
\hline 5.07 & 2.65 & 1.49 & ND & 4.12 & 0.25 & 4.20 & 0.21 & 2.71 \\
\hline 3.72 & 3.44 & 2.10 & ND & 3.67 & 0.24 & ND & 0.14 & ND \\
\hline 4.63 & 2.66 & 2.10 & 1.25 & 3.65 & 0.18 & 4.90 & 0.14 & 2.90 \\
\hline 3.37 & 10.80 & 1.70 & 1.09 & 2.92 & 0.16 & ND & 4.73 & 2.90 \\
\hline 4.22 & 3.52 & 2.40 & 1.78 & 3.07 & 0.24 & 3.90 & 0.74 & 2.50 \\
\hline 1.83 & 10.27 & 1.87 & ND & 2.90 & 0.19 & 3.04 & 0.32 & 2.86 \\
\hline 3.10 & 2.19 & 2.80 & 2.36 & 2.74 & 0.20 & 3.90 & 0.25 & 1.40 \\
\hline 3.40 & 3.45 & 2.60 & ND & 2.83 & 0.19 & 4.00 & 0.25 & 2.80 \\
\hline 4.60 & 3.11 & 1.67 & ND & 3.11 & 0.19 & 4.20 & 0.28 & 3.11 \\
\hline 2.45 & 44.90 & 0.20 & ND & 0.38 & 0.24 & 1.90 & 0.17 & 36.20 \\
\hline 4.48 & 2.01 & 2.80 & 2.27 & 2.50 & 0.22 & 4.30 & 0.72 & 1.30 \\
\hline 3.60 & 3.14 & 3.10 & 2.71 & 2.26 & 0.20 & 3.50 & 0.41 & 2.30 \\
\hline 2.90 & 3.21 & 2.74 & ND & 2.36 & 0.18 & 3.13 & 0.13 & 1.98 \\
\hline 5.42 & 2.73 & 2.90 & 2.51 & 1.97 & 0.21 & 4.70 & 0.97 & 1.60 \\
\hline 6.47 & 6.97 & 2.70 & ND & 1.69 & 0.17 & 5.20 & 0.80 & 1.60 \\
\hline 7.37 & 2.54 & 2.90 & 2.35 & 1.47 & 0.19 & ND & 3.67 & 0.90 \\
\hline 6.00 & 1.94 & 2.70 & 2.24 & 2.05 & 0.22 & ND & 1.45 & 1.00 \\
\hline 7.82 & 1.20 & 3.00 & 2.46 & 1.55 & 0.21 & 5.70 & 0.34 & 0.90 \\
\hline 7.87 & 1.09 & 2.74 & ND & 1.46 & 0.22 & 4.65 & 0.34 & 0.77 \\
\hline 7.84 & 0.47 & 3.00 & 2.49 & 1.58 & 0.20 & 5.90 & 0.08 & 1.00 \\
\hline 7.26 & 0.46 & 2.90 & ND & 1.78 & 0.21 & 5.40 & 0.14 & 1.00 \\
\hline 7.03 & 0.51 & 2.70 & ND & 1.93 & 0.21 & 5.40 & 0.22 & 0.90 \\
\hline 5.23 & 2.86 & 3.20 & 2.81 & 1.10 & 0.16 & ND & 1.68 & 0.50 \\
\hline 7.36 & 1.28 & 2.60 & 2.18 & 1.73 & 0.21 & 5.50 & 0.60 & 1.10 \\
\hline 7.56 & 0.69 & 2.60 & 2.21 & 1.88 & 0.21 & 5.40 & 0.21 & 0.80 \\
\hline 6.39 & 1.12 & 3.20 & 2.73 & 1.48 & 0.24 & 4.80 & 0.57 & 0.70 \\
\hline 4.53 & 1.25 & 3.70 & ND & 1.00 & 0.21 & 3.50 & 0.76 & 0.50 \\
\hline 4.92 & 0.60 & 4.70 & 4.35 & 0.65 & 0.23 & ND & 1.65 & 0.60 \\
\hline 7.73 & 0.72 & 3.90 & 3.39 & 0.97 & 0.21 & 5.20 & 0.33 & 0.90 \\
\hline 6.13 & 1.40 & 3.30 & 2.96 & 1.66 & 0.16 & 4.60 & 0.66 & 1.10 \\
\hline 6.65 & 0.93 & 4.00 & 3.74 & 1.31 & 0.19 & 4.90 & 0.43 & 1.00 \\
\hline 4.82 & 1.87 & 4.20 & 3.92 & 1.40 & 0.22 & 4.30 & 0.33 & 1.40 \\
\hline 4.90 & 2.69 & 4.10 & 3.71 & 1.50 & 0.22 & ND & 1.24 & 2.10 \\
\hline 3.91 & 2.23 & 4.90 & 4.62 & 0.61 & 0.20 & ND & 1.44 & 0.60 \\
\hline 4.17 & 4.31 & 3.80 & 3.58 & 0.90 & 0.18 & ND & 2.28 & 1.10 \\
\hline 3.72 & 7.74 & 4.00 & ND & 0.43 & 0.13 & ND & 4.73 & 0.10 \\
\hline 6.72 & 1.37 & 4.10 & 3.86 & 1.18 & 0.23 & ND & 1.39 & 1.00 \\
\hline 6.44 & 1.38 & 4.30 & 4.04 & 1.15 & 0.23 & 4.60 & 0.32 & 0.90 \\
\hline 6.36 & 1.33 & 3.90 & 3.67 & 1.63 & 0.23 & ND & 1.25 & 0.90 \\
\hline 5.02 & 2.23 & 3.60 & ND & 0.14 & 0.18 & 3.70 & 0.24 & 0.50 \\
\hline 17.90 & 1.85 & 4.60 & ND & 0.96 & 0.06 & ND & 2.17 & ND \\
\hline 22.39 & 2.64 & 1.47 & ND & 0.69 & 0.09 & ND & 2.83 & 4.62 \\
\hline 3.96 & 6.45 & 4.00 & ND & 2.13 & 0.17 & ND & 2.53 & 6.60 \\
\hline 3.71 & 3.61 & 1.87 & ND & 3.22 & 0.24 & 5.00 & 0.53 & 3.26 \\
\hline 4.63 & 3.19 & 3.60 & 2.23 & 2.10 & 0.22 & ND & 2.55 & 2.80 \\
\hline 5.82 & 3.54 & 3.20 & 1.89 & 2.29 & 0.19 & 5.60 & 0.53 & 4.10 \\
\hline 6.49 & 2.25 & 1.97 & ND & 2.95 & 0.22 & 5.54 & 0.79 & 3.30 \\
\hline 5.32 & 1.53 & 3.20 & 2.46 & 2.57 & 0.20 & ND & 2.08 & 0.90 \\
\hline 8.50 & 1.10 & 3.10 & 1.89 & 2.30 & 0.24 & ND & 2.10 & 0.90 \\
\hline 6.26 & 1.64 & 3.50 & 2.41 & 2.49 & 0.20 & ND & 1.14 & 0.70 \\
\hline 7.46 & 1.21 & 3.10 & 1.70 & 2.34 & 0.17 & 5.40 & 0.92 & 0.90 \\
\hline 8.85 & 1.20 & 1.97 & ND & 2.47 & 0.18 & 5.00 & 0.89 & ND \\
\hline 6.37 & 6.62 & 0.25 & ND & 0.09 & 0.04 & ND & 33.00 & 9.80 \\
\hline 6.81 & 0.35 & 0.74 & ND & 0.21 & 0.04 & ND & 31.50 & 6.80 \\
\hline 6.62 & 28.20 & 0.45 & 0.11 & 0.18 & 0.22 & ND & 17.60 & 0.20 \\
\hline 8.78 & 3.01 & 0.65 & ND & 0.14 & 0.07 & ND & 31.20 & 0.80 \\
\hline 5.79 & 19.20 & 0.64 & ND & 0.17 & 0.22 & ND & 25.10 & 0.50 \\
\hline 8.89 & 1.13 & 1.12 & ND & 0.64 & 0.15 & ND & 12.00 & 0.60 \\
\hline 5.14 & 0.78 & 1.49 & ND & 1.58 & 0.15 & 3.49 & 1.74 & 0.70 \\
\hline
\end{tabular}


Table 1 (continued).

\begin{tabular}{|c|c|c|c|c|c|c|c|c|c|c|c|c|c|c|c|c|}
\hline & & & & Udepth & Ldepth & Depth & & & Moisture & $\mathrm{SiO}_{2}$ & $\mathrm{TiO}_{2}$ & $\mathrm{Al}_{2} \mathrm{O}_{3}$ & $\mathrm{Fe}_{2} \mathrm{O}_{3} \mathrm{~T}$ & $\mathrm{Fe}_{2} \mathrm{O}_{3}$ & $\mathrm{FeO}$ & $\mathrm{MnO}$ \\
\hline Leg & Hole & Core & Section & $(\mathrm{cm})$ & $(\mathrm{cm})$ & (mbsf) & Lithology & Induration & \multicolumn{8}{|c|}{$\mathrm{wt} \%$} \\
\hline 139 & $858 \mathrm{C}$ & $12 \mathrm{X}$ & 2 & 80 & 82 & 66.30 & SLCS & indurated & 28.4 & 57.10 & 0.84 & -15.80 & 7.50 & 0.20 & 6.80 & 0.16 \\
\hline 139 & $858 \mathrm{C}$ & $12 \mathrm{X}$ & 3 & 87 & 90 & 67.87 & SNST & indurated & ND & 63.09 & 0.98 & 16.19 & 7.38 & ND & ND & 0.14 \\
\hline 139 & $858 \mathrm{C}$ & $12 \mathrm{X}$ & $\mathrm{CC}$ & 8 & 10 & 68.14 & SNSL & indurated & 15.5 & 69.20 & 0.75 & 13.30 & 3.70 & ND & ND & 0.06 \\
\hline 139 & $858 \mathrm{C}$ & $13 \mathrm{X}$ & 1 & 1 & 16 & 73.71 & SNSL & indurated & ND & 61.84 & 0.95 & 15.96 & 7.71 & ND & ND & 0.15 \\
\hline 139 & $858 \mathrm{C}$ & $13 \mathrm{X}$ & 1 & 25 & 28 & 73.95 & SLCS & indurated & 24.4 & 58.40 & 0.86 & 15.70 & 7.30 & 0.20 & 6.40 & 0.15 \\
\hline 139 & $858 \mathrm{C}$ & $14 \mathrm{X}$ & 1 & 34 & 36 & 83.74 & SNSL & indurated & ND & 61.72 & 0.96 & 17.25 & 8.42 & ND & ND & 0.14 \\
\hline 139 & $858 \mathrm{C}$ & $14 \mathrm{X}$ & 1 & 49 & 51 & 83.87 & SLCS & indurated & ND & 59.10 & 0.84 & 16.10 & 7.30 & ND & ND & 0.12 \\
\hline 139 & 858D & $01 \mathrm{H}$ & 1 & 105 & 107 & 1.05 & SILT & weak & ND & 47.10 & 0.69 & 14.00 & 6.90 & ND & ND & 0.15 \\
\hline 139 & $858 \mathrm{D}$ & $01 \mathrm{H}$ & 1 & 115 & 119 & 1.15 & SLCY & non & 46.4 & 50.90 & 0.79 & 15.10 & 7.30 & ND & ND & 0.11 \\
\hline 139 & 858D & $01 \mathrm{H}$ & 3 & 27 & 31 & 3.27 & SLCY & non & 42.6 & 55.70 & 0.90 & 15.50 & 7.50 & ND & ND & 0.07 \\
\hline 139 & $858 \mathrm{D}$ & $01 \mathrm{H}$ & 3 & 98 & 102 & 3.98 & SLCY & weak & ND & 59.71 & 1.01 & 17.44 & 8.28 & ND & ND & 0.09 \\
\hline 139 & 858D & $01 \mathrm{H}$ & 3 & 112 & 115 & 4.12 & SILT & weak & 3.5 & 55.20 & 0.83 & 16.00 & 7.00 & 2.60 & 4.00 & 0.09 \\
\hline 139 & $858 \mathrm{D}$ & $01 \mathrm{H}$ & 4 & 80 & 83 & 5.30 & SLCY & weak & 5.3 & 51.20 & 0.78 & 14.80 & 7.10 & 2.40 & 4.20 & 0.11 \\
\hline 139 & $858 \mathrm{D}$ & $01 \mathrm{H}$ & 5 & 84 & 88 & 6.84 & SLCY & weak & 38.6 & 54.40 & 0.94 & 14.90 & 7.10 & 2.40 & 4.20 & 0.11 \\
\hline 139 & 858D & $01 \mathrm{H}$ & 5 & 106 & 110 & 7.06 & SILT & weak & 1.8 & 55.50 & 0.89 & 14.80 & 6.80 & 2.50 & 3.90 & 0.10 \\
\hline 139 & $858 \mathrm{D}$ & $01 \mathrm{H}$ & 6 & 25 & 28 & 7.75 & SILT & weak & ND & 52.10 & 0.77 & 15.70 & 6.70 & 2.10 & 4.10 & 0.12 \\
\hline 139 & $858 \mathrm{D}$ & $01 \mathrm{H}$ & 6 & 30 & 33 & 7.80 & SLCY & weak & ND & 58.74 & 0.91 & 17.97 & 8.25 & ND & ND & 0.12 \\
\hline 139 & 858D & $02 \mathrm{H}$ & 1 & 115 & 117 & 10.45 & SLCY & weak & 46.2 & 49.10 & 0.66 & 14.40 & 6.40 & 1.50 & 4.40 & 0.08 \\
\hline 139 & $858 \mathrm{D}$ & $02 \mathrm{H}$ & 1 & 128 & 131 & 10.58 & SLCY & weak & 1.8 & 47.90 & 0.65 & 14.20 & 6.00 & 0.90 & 4.60 & 0.09 \\
\hline 139 & 858D & $02 \mathrm{H}$ & 2 & 76 & 78 & 11.56 & SLCY & weak & 47.1 & 55.00 & 0.76 & 15.30 & 7.30 & ND & ND & 0.07 \\
\hline 139 & $858 \mathrm{D}$ & $\mathrm{O} 2 \mathrm{H}$ & 2 & 95 & 98 & 11.75 & SILT & weak & ND & 53.70 & 0.78 & 15.40 & 7.00 & 1.30 & 5.10 & 0.07 \\
\hline 139 & 858D & $02 \mathrm{H}$ & 2 & 111 & 113 & 11.91 & SLCY & weak & ND & 59.48 & 0.91 & 17.03 & 9.46 & ND & ND & 0.09 \\
\hline 139 & 858D & $02 \mathrm{H}$ & 3 & 34 & 36 & 12.64 & SLCY & weak & 38.8 & 57.20 & 0.84 & 15.80 & 6.60 & 1.00 & 5.00 & 0.07 \\
\hline 139 & 858D & $02 \mathrm{H}$ & 3 & 133 & 136 & 13.63 & SLCY & weak & ND & 53.70 & 0.78 & 15.90 & 7.80 & 2.10 & 5.10 & 0.08 \\
\hline 139 & 858D & $02 \mathrm{H}$ & 4 & 46 & 48 & 14.26 & SLCY & weak & 36.6 & 55.20 & 0.84 & 16.60 & 7.70 & 1.60 & 5.50 & 0.07 \\
\hline 139 & 858D & $02 \mathrm{H}$ & 4 & 57 & 60 & 14.37 & SLCY & indurated & ND & 53.40 & 0.79 & 16.20 & 7.80 & 1.80 & 5.40 & 0.08 \\
\hline 139 & $858 \mathrm{D}$ & $02 \mathrm{H}$ & 5 & 36 & 39 & 15.66 & SLCY & indurated & ND & 55.10 & 0.83 & 16.40 & 7.60 & 0.90 & 6.00 & 0.08 \\
\hline 139 & 858D & $02 \mathrm{H}$ & 5 & 53 & 55 & 15.83 & SLCY & moderate & 41.9 & 53.20 & 0.88 & 16.60 & 7.90 & 1.30 & 5.90 & 0.08 \\
\hline 139 & $858 \mathrm{D}$ & $02 \mathrm{H}$ & 6 & 36 & 38 & 17.16 & SLCY & moderate & 36.6 & 54.50 & 0.80 & 16.50 & 8.30 & ND & ND & 0.12 \\
\hline 139 & 858D & $02 \mathrm{H}$ & 6 & 93 & 96 & 17.73 & SILT & moderate & ND & 49.30 & 0.73 & 14.80 & 7.80 & ND & ND & 0.18 \\
\hline 139 & 858D & $02 \mathrm{H}$ & 7 & 14 & 16 & 18.44 & SLCY & indurated & 1.8 & 54.40 & 0.70 & 14.50 & 9.60 & ND & ND & 0.12 \\
\hline 139 & $858 \mathrm{D}$ & $02 \mathrm{H}$ & 7 & 23 & 25 & 18.53 & SLCY & moderate & ND & 60.81 & 0.82 & 15.96 & 9.39 & ND & ND & 0.11 \\
\hline 139 & 858D & $02 \mathrm{H}$ & $\mathrm{CC}$ & 10 & 12 & 18.92 & SLCY & weak & 27.1 & 52.90 & 0.72 & 13.50 & 10.80 & ND & ND & 0.10 \\
\hline 139 & 858D & $04 \mathrm{H}$ & 3 & 31 & 35 & 21.85 & SLCY & slightly & 38.8 & 61.90 & 0.80 & 15.70 & 5.30 & ND & ND & 0.05 \\
\hline 139 & 858D & $04 \mathrm{H}$ & 3 & 107 & 110 & 22.61 & SLCY & indurated & ND & 56.60 & 0.83 & 17.20 & 6.50 & 0.20 & 5.90 & 0.08 \\
\hline 139 & $858 \mathrm{D}$ & $04 \mathrm{H}$ & 4 & 59 & 63 & 23.63 & SILT & indurated & ND & 69.32 & 0.81 & 15.94 & 4.55 & ND & ND & 0.06 \\
\hline 139 & $858 \mathrm{D}$ & $04 \mathrm{H}$ & 4 & 64 & 67 & 23.68 & SLCY & indurated & 1.8 & 63.10 & 0.70 & 14.30 & 5.40 & ND & ND & 0.05 \\
\hline 139 & $858 \mathrm{D}$ & $04 \mathrm{H}$ & 5 & 35 & 33 & 24.87 & SLCU & indurated & 1.8 & 60.50 & 0.75 & 15.90 & 5.20 & ND & ND & 0.08 \\
\hline 139 & $858 \mathrm{D}$ & $04 \mathrm{H}$ & 5 & 44 & 48 & 24.98 & SLCY & moderate & 29.8 & 61.50 & 0.71 & 15.70 & 5.30 & ND & ND & 0.07 \\
\hline 139 & $858 \mathrm{D}$ & $04 \mathrm{H}$ & 6 & 26 & 29 & 26.30 & SLCY & indurated & 1.7 & 63.70 & 0.77 & 14.00 & 5.40 & ND & ND & 0.06 \\
\hline 139 & $858 \mathrm{D}$ & $04 \mathrm{H}$ & 7 & 36 & 40 & 27.90 & SNSL & indurated & 27.9 & 60.70 & 0.65 & 13.90 & 5.80 & ND & ND & 0.16 \\
\hline 139 & $858 \mathrm{~F}$ & $02 \mathrm{R}$ & $\mathrm{CC}$ & 8 & 11 & 27.87 & SNSL & indurated & ND & 71.50 & 0.47 & 9.50 & 4.10 & ND & ND & 0.12 \\
\hline 139 & $858 \mathrm{~F}$ & $04 \mathrm{R}$ & $\mathrm{CC}$ & 8 & 10 & 46.58 & SNST & indurated & ND & 75.60 & 0.48 & 9.00 & 3.90 & 0.20 & 3.40 & 0.08 \\
\hline 139 & $858 \mathrm{~F}$ & $08 \mathrm{R}$ & $\mathrm{CC}$ & 11 & 12 & 84.81 & SNST & indurated & ND & 72.00 & 0.49 & 12.40 & 1.80 & 0.20 & 1.50 & 0.03 \\
\hline 139 & $858 \mathrm{~F}$ & $09 \mathrm{R}$ & 1 & 18 & 20 & 94.38 & SNST & indurated & ND & 76.53 & 0.38 & 13.36 & 1.59 & ND & ND & 0.03 \\
\hline 139 & $858 \mathrm{~F}$ & $11 \mathrm{R}$ & $\mathrm{CC}$ & 4 & 5 & 114.01 & SNST & indurated & ND & 66.90 & 0.48 & 14.90 & 2.40 & 0.20 & 2.00 & 0.04 \\
\hline 139 & $858 \mathrm{~F}$ & $12 \mathrm{R}$ & $\mathrm{CC}$ & 2 & 3 & 123.32 & CLST & moderate & 18.9 & 57.00 & 0.86 & 15.80 & 8.50 & 0.60 & 7.10 & 0.14 \\
\hline 139 & $858 \mathrm{~F}$ & $13 \mathrm{R}$ & $\mathrm{CC}$ & 6 & 7 & 132.96 & CLST & moderate & 9.8 & 31.10 & 0.53 & 7.98 & 34.20 & ND & ND & 0.06 \\
\hline 139 & $858 \mathrm{~F}$ & $13 R$ & 1 & 7 & 9 & 132.97 & SLST & indurated & ND & 66.83 & 0.80 & 14.15 & 5.48 & ND & ND & 0.08 \\
\hline 139 & $858 \mathrm{~F}$ & $14 \mathrm{R}$ & 1 & 10 & 12 & 142.70 & SLST & indurated & 3.8 & 60.30 & 0.77 & 15.10 & 5.80 & ND & ND & 0.09 \\
\hline 139 & $858 \mathrm{~F}$ & $15 R$ & 1 & 4 & 6 & 152.24 & SNST & indurated & ND & 62.60 & 0.56 & 14.70 & 3.80 & ND & ND & 0.05 \\
\hline 139 & $858 \mathrm{~F}$ & $17 \mathrm{R}$ & 1 & 16 & 18 & 171.76 & STSS & indurated & ND & 69.60 & 0.46 & 14.40 & 1.90 & ND & ND & 0.02 \\
\hline 139 & $858 \mathrm{~F}$ & $18 \mathrm{R}$ & 1 & 14 & 16 & 181.44 & SLST & indurated & 1.7 & 65.60 & 0.63 & 13.50 & 6.00 & 0.40 & 5.00 & 0.08 \\
\hline 139 & $858 \mathrm{~F}$ & $21 \mathrm{R}$ & 1 & 14 & 16 & 210.44 & CLST & indurated & 2.0 & 55.50 & 0.89 & 16.50 & 8.40 & 0.20 & 7.60 & 0.15 \\
\hline 139 & $858 \mathrm{~F}$ & $23 R$ & 1 & 3 & 5 & 229.63 & SNST & indurated & ND & 70.30 & 0.57 & 13.40 & 3.10 & ND & ND & 0.06 \\
\hline 139 & $858 \mathrm{~F}$ & $25 R$ & 1 & 9 & 11 & 248.99 & CLST & indurated & 1.7 & 57.80 & 0.92 & 16.30 & 6.60 & ND & ND & 0.13 \\
\hline 139 & $858 \mathrm{~F}$ & $25 \mathrm{R}$ & 1 & 19 & 21 & 249.09 & CLST & indurated & ND & 55.50 & 0.90 & 16.90 & 7.10 & 0.40 & 6.00 & 0.15 \\
\hline 139 & $858 \mathrm{~F}$ & $25 \mathrm{R}$ & 1 & 40 & 42 & 249.30 & CLST & indurated & ND & 55.37 & 1.10 & 18.53 & 8.29 & ND & ND & 0.17 \\
\hline 139 & $858 \mathrm{~F}$ & $25 \mathrm{R}$ & 1 & 61 & 63 & 249.51 & SLST & indurated & ND & 55.60 & 0.86 & 14.70 & 10.20 & ND & ND & 0.12 \\
\hline 139 & $858 \mathrm{~F}$ & $25 \mathrm{R}$ & 1 & 71 & 73 & 249.61 & CLST & indurated & 1.8 & 52.80 & 0.92 & 16.70 & 8.50 & ND & ND & 0.16 \\
\hline
\end{tabular}


Table 1 (continued).

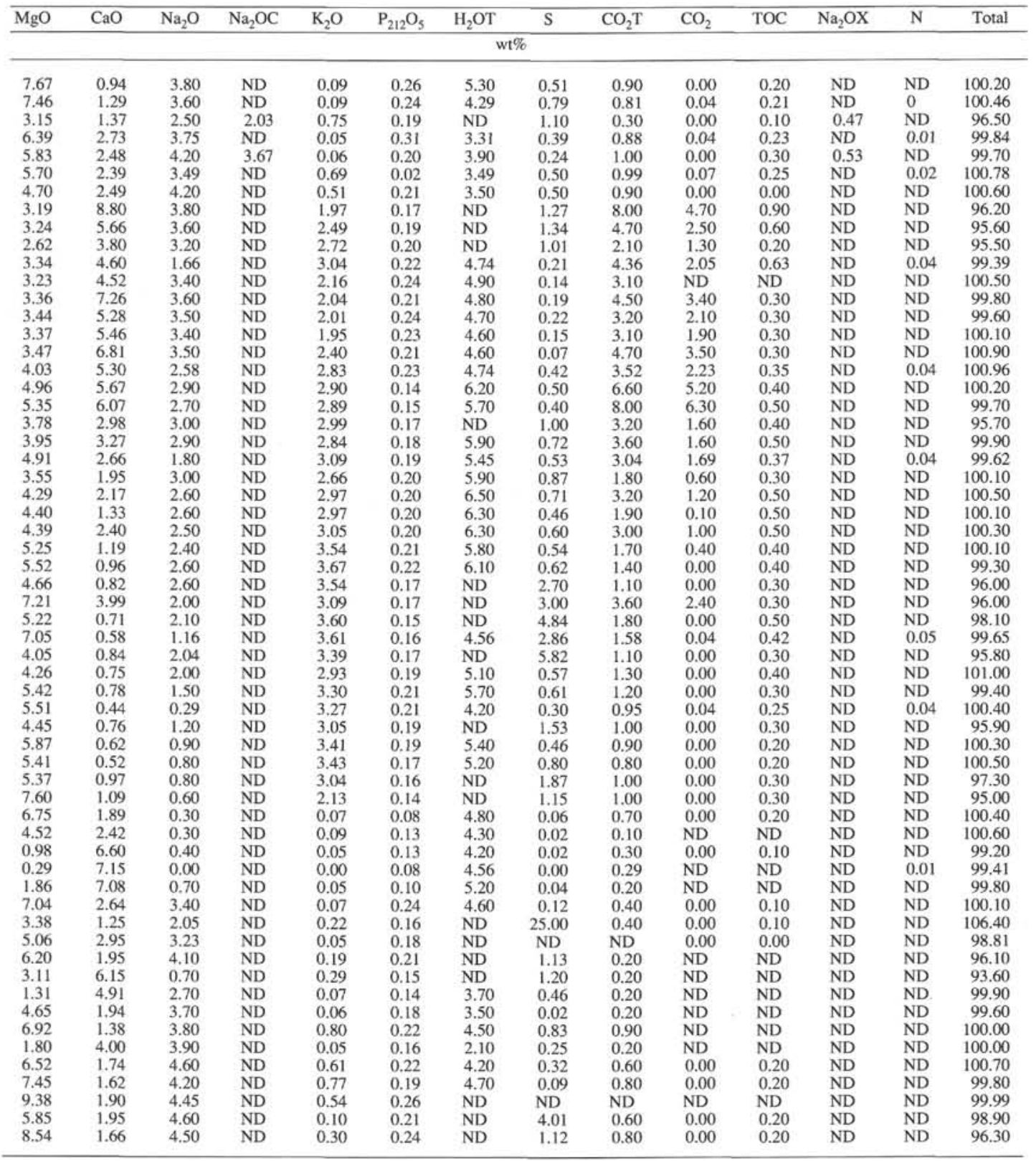


Table 1 (continued).

\begin{tabular}{|c|c|c|c|c|c|c|c|}
\hline & & & & Udepth & Ldepth & Depth & \\
\hline Leg & Hole & Core & Section & $(\mathrm{cm})$ & $(\mathrm{cm})$ & (mbsf) & $\mathrm{Ba}$ \\
\hline 139 & $855 \mathrm{~A}$ & $01 \mathrm{R}$ & 2 & 77 & 79 & 2.27 & 590 \\
\hline 139 & $855 \mathrm{~A}$ & OIR & 4 & 70 & 74 & 5.20 & 700 \\
\hline 139 & $855 \mathrm{~A}$ & OIR & 4 & 111 & 114 & 5.61 & 784 \\
\hline 139 & $855 \mathrm{~A}$ & $02 R$ & 1 & 71 & 73 & 8.31 & 860 \\
\hline 139 & $855 \mathrm{~A}$ & $02 R$ & 3 & 43 & 45 & 11.02 & 847 \\
\hline 139 & $855 \mathrm{~A}$ & $02 R$ & 3 & 69 & 71 & 11.29 & 740 \\
\hline 139 & $855 \mathrm{~A}$ & 03R & 2 & 80 & 82 & 18.90 & 746 \\
\hline 139 & $855 \mathrm{~A}$ & $04 R$ & 1 & 112 & 115 & 27.12 & 750 \\
\hline 139 & $855 \mathrm{~A}$ & $04 \mathrm{R}$ & 3 & 96 & 98 & 29.96 & 710 \\
\hline 139 & $855 \mathrm{~A}$ & $04 \mathrm{R}$ & 4 & 81 & 83 & 31.31 & 520 \\
\hline 139 & $855 \mathrm{~A}$ & $05 R$ & 1 & 4 & 6 & 35.54 & 620 \\
\hline 139 & $855 \mathrm{~A}$ & 06R & 1 & 100 & 104 & 46.50 & 540 \\
\hline 139 & $855 \mathrm{~A}$ & $07 \mathrm{R}$ & 3 & 65 & 67 & 58.75 & 770 \\
\hline 139 & $855 \mathrm{~B}$ & $02 R$ & 1 & 106 & 110 & 6.76 & 840 \\
\hline 139 & $855 \mathrm{~B}$ & $04 R$ & 1 & 128 & 132 & 25.78 & 610 \\
\hline 139 & $855 \mathrm{~B}$ & $04 \mathrm{R}$ & 3 & 122 & 126 & 28.72 & 590 \\
\hline 139 & $855 \mathrm{~B}$ & $04 \mathrm{R}$ & 4 & 57 & 61 & 29.57 & 490 \\
\hline 139 & $855 \mathrm{~B}$ & $04 R$ & 4 & 99 & 102 & 29.99 & 568 \\
\hline 139 & $855 \mathrm{~B}$ & $04 R$ & 5 & 118 & 122 & 31.68 & 840 \\
\hline 139 & $855 \mathrm{~B}$ & 05R & 1 & 25 & 28 & 34.25 & 507 \\
\hline 139 & $855 \mathrm{C}$ & OIR & 1 & 57 & 61 & 0.57 & 710 \\
\hline 139 & $855 \mathrm{C}$ & OIR & 3 & 55 & 57 & 3.55 & 670 \\
\hline 139 & $855 \mathrm{C}$ & $01 R$ & 5 & 56 & 58 & 6.56 & 770 \\
\hline 139 & $855 \mathrm{C}$ & $02 R$ & 1 & 53 & 57 & 9.23 & 740 \\
\hline 139 & $855 \mathrm{C}$ & $02 R$ & 3 & 54 & 58 & 12.24 & 760 \\
\hline 139 & $855 \mathrm{C}$ & $02 \mathrm{R}$ & 5 & 52 & 56 & 15.22 & 1300 \\
\hline 139 & $855 \mathrm{C}$ & $03 R$ & 1 & 45 & 47 & 18.15 & 860 \\
\hline 139 & $855 \mathrm{C}$ & $04 \mathrm{R}$ & 1 & 87 & 89 & 27.97 & 850 \\
\hline 139 & $855 \mathrm{C}$ & $04 \mathrm{R}$ & 3 & 103 & 105 & 31.13 & 640 \\
\hline 139 & $855 \mathrm{C}$ & $06 \mathrm{R}$ & 1 & 128 & 132 & 47.78 & 600 \\
\hline 139 & $855 \mathrm{C}$ & $06 \mathrm{R}$ & 2 & 2 & 6 & 48.02 & 70 \\
\hline 139 & $855 C$ & $06 \mathrm{R}$ & 3 & 130 & 134 & 50.80 & 590 \\
\hline 139 & $855 \mathrm{C}$ & $06 \mathrm{R}$ & 5 & 76 & 80 & 53.26 & 616 \\
\hline 139 & $855 \mathrm{C}$ & $07 R$ & 1 & 76 & 80 & 56.86 & 793 \\
\hline 139 & $855 \mathrm{C}$ & 07R & 2 & 83 & 87 & 58.43 & 580 \\
\hline 139 & $855 \mathrm{C}$ & $07 \mathrm{R}$ & 4 & 80 & 84 & 61.40 & 630 \\
\hline 139 & $855 \mathrm{C}$ & $07 \mathrm{R}$ & 6 & 60 & 64 & 64.20 & 470 \\
\hline 139 & $855 \mathrm{C}$ & 08R & 2 & 33 & 36 & 66.78 & 593 \\
\hline 139 & $855 \mathrm{C}$ & $08 \mathrm{R}$ & 2 & $A C$ & 44 & 66.85 & 590 \\
\hline 139 & $855 \mathrm{C}$ & $10 \mathrm{R}$ & 1 & 130 & 134 & 86.20 & 550 \\
\hline 139 & $855 \mathrm{C}$ & $10 \mathrm{R}$ & 4 & 51 & 55 & 88.41 & 950 \\
\hline 139 & $855 \mathrm{C}$ & $10 \mathrm{R}$ & 5 & 43 & 47 & 89.83 & 524 \\
\hline 139 & $855 \mathrm{C}$ & $11 \mathrm{R}$ & 1 & 67 & 70 & 95.27 & 456 \\
\hline 139 & $855 \mathrm{C}$ & $11 R$ & 1 & 115 & 119 & 95.75 & 410 \\
\hline 139 & $856 \mathrm{~A}$ & $01 \mathrm{H}$ & 1 & 69 & 72 & 0.69 & 934 \\
\hline 139 & $856 \mathrm{~A}$ & $01 \mathrm{H}$ & 1 & 95 & 98 & 0.95 & 870 \\
\hline 139 & $856 \mathrm{~A}$ & $02 \mathrm{H}$ & 1 & 45 & 47 & 3.15 & 570 \\
\hline 139 & $856 \mathrm{~A}$ & $02 \mathrm{H}$ & 2 & 62 & 64 & 4.82 & 740 \\
\hline 139 & $856 \mathrm{~A}$ & $03 \mathrm{H}$ & 1 & 107 & 111 & 13.27 & 590 \\
\hline 139 & $856 \mathrm{~A}$ & $03 \mathrm{H}$ & 2 & 67 & 71 & 14.37 & 730 \\
\hline 139 & $856 \mathrm{~A}$ & 03H & 5 & 117 & 121 & 19.37 & 480 \\
\hline 139 & $856 \mathrm{~A}$ & $03 \mathrm{H}$ & 6 & 8 & 9 & 19.78 & 240 \\
\hline 139 & $856 \mathrm{~A}$ & $03 \mathrm{H}$ & 7 & 1 & 16 & 21.32 & 660 \\
\hline 139 & $856 \mathrm{~A}$ & $04 \mathrm{H}$ & 2 & 37 & 41 & 23.57 & 600 \\
\hline 139 & $856 \mathrm{~A}$ & $04 \mathrm{H}$ & 2 & 86 & 90 & 24.06 & 762 \\
\hline 139 & $856 \mathrm{~A}$ & $04 \mathrm{H}$ & 4 & 36 & 40 & 26.56 & 600 \\
\hline 139 & $856 \mathrm{~A}$ & $04 \mathrm{H}$ & 6 & 55 & 59 & 29.75 & 520 \\
\hline 139 & $856 \mathrm{~A}$ & $05 \mathrm{H}$ & 2 & 73 & 77 & 32.31 & 580 \\
\hline 139 & $856 \mathrm{~A}$ & $05 \mathrm{H}$ & 3 & 73 & 77 & 33.81 & 711 \\
\hline 139 & $856 \mathrm{~A}$ & $05 \mathrm{H}$ & 4 & 91 & 95 & 35.49 & 540 \\
\hline 139 & $856 \mathrm{~A}$ & $05 \mathrm{H}$ & 5 & 29 & 31 & 36.37 & 700 \\
\hline 139 & $856 \mathrm{~A}$ & $05 \mathrm{H}$ & 8 & 71 & 75 & 41.29 & 650 \\
\hline 139 & $856 \mathrm{~A}$ & $06 \mathrm{H}$ & 1 & 79 & 84 & 41.49 & 610 \\
\hline 139 & $856 \mathrm{~A}$ & $06 \mathrm{H}$ & 2 & 88 & 92 & 43.08 & 581 \\
\hline 139 & $856 \mathrm{~A}$ & $06 \mathrm{H}$ & 2 & 144 & 148 & 43.64 & 680 \\
\hline 139 & $856 \mathrm{~A}$ & $06 \mathrm{H}$ & 3 & 103 & 107 & 44.73 & 580 \\
\hline 139 & $856 \mathrm{~A}$ & $06 \mathrm{H}$ & 4 & 69 & 77 & 45.89 & 560 \\
\hline 139 & $856 \mathrm{~A}$ & $06 \mathrm{H}$ & 4 & 89 & 94 & 46.09 & 490 \\
\hline 139 & $856 \mathrm{~A}$ & $06 \mathrm{H}$ & 5 & 104 & 106 & 47.74 & 560 \\
\hline 139 & $856 \mathrm{~A}$ & $06 \mathrm{H}$ & 6 & 90 & 94 & 49.10 & 530 \\
\hline 139 & $856 \mathrm{~A}$ & $06 \mathrm{H}$ & 7 & 61 & 65 & 50.31 & 660 \\
\hline 139 & $856 \mathrm{~A}$ & $07 \mathrm{H}$ & 1 & 89 & 93 & 51.09 & 610 \\
\hline 139 & $856 \mathrm{~A}$ & 07H & 2 & 95 & 99 & 52.65 & 488 \\
\hline 139 & $856 \mathrm{~A}$ & $07 \mathrm{H}$ & 3 & 0 & 3 & 53.20 & ND \\
\hline 139 & $856 \mathrm{~A}$ & $07 \mathrm{H}$ & 3 & 81 & 85 & 54.01 & 610 \\
\hline 139 & $856 \mathrm{~A}$ & $07 \mathrm{H}$ & 5 & 70 & 74 & 56.90 & 580 \\
\hline 139 & $856 \mathrm{~A}$ & $07 \mathrm{H}$ & 6 & 139 & 142 & 59.09 & 500 \\
\hline 139 & $856 \mathrm{~A}$ & $07 \mathrm{H}$ & 7 & 55 & 59 & 59.75 & 530 \\
\hline 139 & $856 \mathrm{~A}$ & $07 \mathrm{H}$ & $\mathrm{CC}$ & 24 & 28 & 60.20 & ND \\
\hline 139 & $856 \mathrm{~A}$ & $08 \mathrm{H}$ & 1 & 4 & 6 & 59.74 & 160 \\
\hline 139 & $856 \mathrm{~A}$ & $08 \mathrm{H}$ & 1 & 8 & 10 & 59.78 & 330 \\
\hline 139 & $856 \mathrm{~A}$ & $08 \mathrm{H}$ & 1 & 97 & 99 & 60.67 & 570 \\
\hline 139 & $856 \mathrm{~A}$ & $08 \mathrm{H}$ & 3 & 23 & 26 & 62.93 & 460 \\
\hline 139 & $856 \mathrm{~A}$ & $08 \mathrm{H}$ & 3 & 66 & 68 & 63.36 & 569 \\
\hline 139 & $856 \mathrm{~A}$ & $08 \mathrm{H}$ & 3 & 72 & 75 & 63.42 & 530 \\
\hline 139 & $856 \mathrm{~A}$ & $08 \mathrm{H}$ & 5 & 84 & 87 & 66.54 & 540 \\
\hline 139 & $856 \mathrm{~A}$ & $08 \mathrm{H}$ & 7 & 26 & 28 & 68.96 & 540 \\
\hline 139 & $856 \mathrm{~A}$ & $09 \mathrm{H}$ & 1 & 4 & 47 & 69.64 & 410 \\
\hline 139 & & & & & & & \\
\hline
\end{tabular}


Table 1 (continued).

\begin{tabular}{|c|c|c|c|c|c|c|c|}
\hline $\mathrm{Ni}$ & $\mathrm{Pb}$ & $\mathrm{Rb}$ & $\mathrm{Sc}$ & $\mathrm{Sr}$ & V & $\mathrm{Y}$ & $\mathrm{Yb}$ \\
\hline & & & & & & & $\mathrm{s}$ per mil \\
\hline 48 & 53 & 87 & 17 & 330 & 130 & 23 & 2.20 \\
\hline 60 & 20 & 65 & 18 & 370 & 130 & 20 & 1.80 \\
\hline 48 & ND & 69 & ND & 343 & 171 & 21 & ND \\
\hline 65 & 20 & 78 & 18 & 350 & 140 & 22 & 2.00 \\
\hline 53 & ND & 157 & ND & 222 & 128 & 21 & ND \\
\hline 59 & 24 & 110 & 18 & 300 & 130 & 21 & 2.00 \\
\hline 69 & ND & 67 & ND & 272 & 183 & 23 & ND \\
\hline 57 & 20 & 70 & 17 & 370 & 140 & 18 & 1.60 \\
\hline 57 & 20 & 60 & 15 & 480 & 120 & 19 & 1.80 \\
\hline 59 & 20 & 51 & 19 & 310 & 140 & 21 & 2.10 \\
\hline 55 & 26 & 57 & 19 & 350 & 150 & 20 & 1.90 \\
\hline 49 & 20 & 52 & 18 & 350 & 130 & 21 & 2,00 \\
\hline 55 & 20 & 64 & 13 & 330 & 100 & 17 & 1.60 \\
\hline 76 & 20 & 73 & 16 & 430 & 130 & 20 & 1.90 \\
\hline 73 & 20 & 52 & 18 & 360 & 130 & 20 & 2.00 \\
\hline 74 & 20 & 60 & 18 & 360 & 140 & 20 & 2.00 \\
\hline 55 & 20 & 37 & 15 & 430 & 100 & 18 & 1.90 \\
\hline 48 & ND & 50 & ND & 354 & 147 & 22 & ND \\
\hline 55 & 21 & 63 & 16 & 480 & 120 & 20 & 2.00 \\
\hline 36 & ND & 38 & ND & 386 & 146 & 23 & ND \\
\hline 48 & 27 & 86 & 16 & 370 & 120 & 21 & 2.10 \\
\hline 54 & 20 & 70 & 16 & 410 & 130 & 20 & 2.00 \\
\hline 49 & 21 & 60 & 16 & 430 & 130 & 19 & 1.80 \\
\hline 73 & 21 & 62 & 18 & 350 & 140 & 20 & 1.90 \\
\hline 72 & 24 & 91 & 18 & 310 & 140 & 20 & 1.90 \\
\hline 64 & 24 & 78 & 17 & 310 & 140 & 20 & 1.90 \\
\hline 74 & 22 & 70 & 17 & 320 & 150 & 18 & 1.60 \\
\hline 67 & 21 & 73 & 18 & 340 & 140 & 21 & 2.00 \\
\hline 53 & ND & 62 & 19 & 360 & 150 & 18 & 1.70 \\
\hline 62 & 39 & 55 & 18 & 330 & 130 & 20 & 1.90 \\
\hline 110 & ND & ND & 35 & 140 & 290 & 39 & 3.80 \\
\hline 53 & ND & 58 & 18 & 360 & 130 & 20 & 1.90 \\
\hline 48 & ND & 57 & ND & 317 & 157 & 22 & ND \\
\hline 55 & ND & 69 & ND & 236 & 194 & 24 & ND \\
\hline 59 & 21 & 67 & 19 & 290 & 140 & 19 & 1.70 \\
\hline 45 & ND & 55 & 16 & 410 & 110 & 18 & 1.70 \\
\hline 46 & ND & 58 & 20 & 300 & 150 & 20 & 1.80 \\
\hline 42 & ND & 57 & ND & 327 & 168 & 23 & ND \\
\hline 51 & ND & 62 & 18 & 340 & 130 & 20 & 1.80 \\
\hline 59 & 20 & 77 & 19 & 280 & 150 & 19 & 1.90 \\
\hline 38 & 20 & 44 & 16 & 420 & 110 & 19 & 1.90 \\
\hline 45 & ND & 63 & ND & 246 & 199 & 24 & ND \\
\hline 28 & ND & 34 & ND & 347 & 145 & 22 & ND \\
\hline 31 & 20 & 31 & 17 & 390 & 130 & 19 & 2.00 \\
\hline 62 & ND & 73 & ND & 416 & 156 & 22 & ND \\
\hline 70 & 22 & 71 & 15 & 480 & 120 & 20 & 1.90 \\
\hline 63 & 23 & 70 & 18 & 340 & 140 & 23 & 2.20 \\
\hline 59 & ND & 86 & ND & 252 & 162 & 24 & ND \\
\hline 63 & 23 & 88 & 15 & 320 & 120 & 22 & 2.10 \\
\hline 49 & ND & 91 & ND & 295 & 151 & 25 & ND \\
\hline 67 & 10 & 66 & 17 & 290 & 130 & 20 & 1.90 \\
\hline 38 & 10 & ND & 10 & 220 & 68 & 25 & 1.90 \\
\hline 68 & 10 & 75 & 16 & 320 & 120 & 20 & 1.90 \\
\hline 54 & 23 & 68 & 14 & 330 & 100 & 19 & 1.80 \\
\hline 61 & ND & 99 & ND & 240 & 152 & 24 & ND \\
\hline 52 & 10 & 64 & 14 & 420 & 99 & 18 & 1.70 \\
\hline 46 & 10 & 43 & 14 & 460 & 110 & 21 & 2.20 \\
\hline 46 & 10 & 50 & 12 & 400 & 89 & 16 & 1.70 \\
\hline 61 & ND & 76 & ND & 259 & 138 & 22 & ND \\
\hline 58 & 10 & 74 & 18 & 250 & 140 & 21 & 2.00 \\
\hline 47 & 10 & 69 & 16 & 260 & 120 & 20 & 1.90 \\
\hline 51 & 10 & 58 & 14 & 360 & 100 & 17 & 1.80 \\
\hline 46 & 10 & 54 & 13 & 390 & 99 & 18 & 1.70 \\
\hline 39 & ND & 49 & ND & 350 & 153 & 19 & ND \\
\hline 68 & 10 & 73 & 17 & 300 & 140 & 19 & 1.80 \\
\hline 49 & 10 & 72 & 15 & 360 & 100 & 21 & 1.90 \\
\hline 36 & 10 & 38 & 11 & 340 & 73 & 18 & 1.80 \\
\hline 44 & 10 & 42 & 15 & 320 & 120 & 19 & 1.90 \\
\hline 54 & 10 & 77 & 20 & 220 & 150 & 22 & 1.90 \\
\hline 49 & 10 & 42 & 14 & 340 & 94 & 19 & 1.70 \\
\hline 65 & 10 & 44 & 16 & 270 & 120 & 20 & 1.80 \\
\hline 59 & 10 & 79 & 18 & 260 & 140 & 20 & 1.80 \\
\hline 32 & ND & 42 & ND & 321 & 148 & 24 & ND \\
\hline 10 & 46 & 17 & 360 & 120 & 19 & 1.8 & 91.00 \\
\hline 64 & 10 & 73 & 20 & 230 & 150 & 20 & 1.70 \\
\hline 72 & 10 & 59 & 19 & 260 & 150 & 18 & 1.60 \\
\hline 74 & 10 & 44 & 15 & 350 & 100 & 17 & 1.70 \\
\hline 65 & 10 & 52 & 18 & 310 & 140 & 20 & 1.90 \\
\hline 10 & 15 & 7 & 270 & 49 & 9 & 0.5 & 57.00 \\
\hline 24 & 10 & 16 & 7.7 & 190 & 55 & 13 & 0.90 \\
\hline 44 & 10 & 30 & 13 & 330 & 96 & 23 & 2.10 \\
\hline 73 & 10 & 60 & 19 & 280 & 150 & 20 & 2.00 \\
\hline 46 & 10 & 31 & 14 & 410 & 110 & 17 & 1.80 \\
\hline 68 & ND & 60 & ND & 197 & 189 & 22 & ND \\
\hline 65 & 10 & 53 & 18 & 290 & 140 & 20 & 1.90 \\
\hline 68 & 10 & 56 & 19 & 280 & 140 & 21 & 1.90 \\
\hline 67 & 10 & 50 & 18 & 300 & 140 & 23 & 2.00 \\
\hline 48 & 20 & 40 & 10 & 280 & 66 & 26 & 2.30 \\
\hline 57 & 10 & 54 & 16 & 260 & 120 & 19 & 1.80 \\
\hline
\end{tabular}


Table 1 (continued).

\begin{tabular}{|c|c|c|c|c|c|c|c|c|}
\hline & & & & Udepth & Ldepth & Depth & & \\
\hline Leg & Hole & Core & Section & $(\mathrm{cm})$ & $(\mathrm{cm})$ & (mbsf) & $\mathrm{Ba}$ & $\mathrm{Ag}$ \\
\hline 139 & $856 \mathrm{~A}$ & $09 \mathrm{H}$ & 1 & 44 & 47 & ND & 410 & 2 \\
\hline 139 & $856 \mathrm{~A}$ & $09 \mathrm{H}$ & 1 & 83 & 87 & 70.03 & 570 & 1 \\
\hline 139 & $856 \mathrm{~A}$ & $09 \mathrm{H}$ & 2 & 94 & 98 & 71.64 & 582 & ND \\
\hline 139 & $856 \mathrm{~A}$ & $\mathrm{O9H}$ & 3 & 63 & 67 & 72.83 & 560 & 1 \\
\hline 139 & $856 \mathrm{~A}$ & $09 \mathrm{H}$ & 4 & 115 & 117 & 74.85 & 370 & 1 \\
\hline 139 & $856 \mathrm{~A}$ & $09 \mathrm{H}$ & 5 & 41 & 42 & 75.61 & 370 & 1 \\
\hline 139 & $856 \mathrm{~A}$ & $09 \mathrm{H}$ & 5 & 80 & 84 & 76.00 & 560 & 1 \\
\hline 139 & $856 \mathrm{~A}$ & O9H & 7 & 59 & 63 & 78.79 & 550 & 1 \\
\hline 139 & $856 \mathrm{~A}$ & $10 x$ & 1 & 68 & 71 & 79.38 & 489 & ND \\
\hline 139 & $856 \mathrm{~A}$ & $10 x$ & 2 & 119 & 122 & 81.39 & 530 & 1 \\
\hline 139 & $856 \mathrm{~A}$ & $10 x$ & 2 & 128 & 130 & 81.48 & 480 & 1 \\
\hline 139 & $856 \mathrm{~A}$ & $11 x$ & 1 & 70 & 72 & 86.90 & 600 & ND \\
\hline 139 & $856 \mathrm{~A}$ & $11 X$ & 1 & 104 & 106 & 87.24 & 754 & ND \\
\hline 139 & $856 \mathrm{~A}$ & $11 X$ & 2 & 47 & 48 & 88.17 & 650 & 1 \\
\hline 139 & $856 \mathrm{~A}$ & $12 \mathrm{X}$ & 1 & 85 & 89 & 96.55 & 691 & ND \\
\hline 139 & $856 \mathrm{~A}$ & $12 \mathrm{X}$ & 1 & 92 & 96 & 96.62 & 690 & 1 \\
\hline 139 & $856 \mathrm{~A}$ & $12 \mathrm{X}$ & 2 & 20 & 24 & 97.40 & 570 & 1 \\
\hline 139 & $856 \mathrm{~A}$ & $13 \mathrm{X}$ & 2 & 13 & 16 & 106.93 & 470 & 1 \\
\hline 139 & $856 \mathrm{~A}$ & $13 \mathrm{X}$ & 2 & 12 & 127 & 108.03 & 533 & ND \\
\hline 139 & $856 \mathrm{~A}$ & $13 \mathrm{X}$ & 4 & 47 & 51 & 110.27 & 280 & 1 \\
\hline 139 & $856 \mathrm{~B}$ & $01 \mathrm{H}$ & 1 & 102 & 106 & 1.02 & 570 & 1 \\
\hline 139 & $856 \mathrm{~B}$ & $01 \mathrm{H}$ & 1 & 123 & 127 & 1.23 & 801 & ND \\
\hline 139 & $856 \mathrm{~B}$ & $02 \mathrm{H}$ & 2 & 3 & 7 & 3.33 & 550 & 1 \\
\hline 139 & $856 \mathrm{~B}$ & $02 \mathrm{H}$ & 3 & 45 & 49 & 5.25 & 783 & ND \\
\hline 139 & $856 \mathrm{~B}$ & $02 \mathrm{H}$ & 5 & 115 & 119 & 8.95 & 660 & 1 \\
\hline 139 & $856 \mathrm{~B}$ & $03 \mathrm{H}$ & 5 & 23 & 25 & 17.53 & 420 & 1 \\
\hline 139 & $856 \mathrm{~B}$ & $03 \mathrm{H}$ & 5 & 110 & 113 & 18.40 & 50 & 2 \\
\hline 139 & $856 \mathrm{~B}$ & $03 \mathrm{H}$ & 5 & 120 & 122 & 18.50 & 30 & 4 \\
\hline 139 & $856 \mathrm{~B}$ & $03 \mathrm{H}$ & 5 & 142 & 144 & 18.72 & 110 & 6 \\
\hline 139 & $856 \mathrm{~B}$ & $03 \mathrm{H}$ & 6 & 34 & 36 & 19.14 & 50 & 5 \\
\hline 139 & $856 \mathrm{~B}$ & $03 \mathrm{H}$ & 7 & 6 & 8 & 20.36 & 50 & 6 \\
\hline 139 & $856 \mathrm{~B}$ & $03 \mathrm{H}$ & 7 & 28 & 30 & 20.58 & 100 & 8 \\
\hline 139 & $856 \mathrm{~B}$ & $03 \mathrm{H}$ & 7 & 32 & 34 & 20.62 & 150 & 8 \\
\hline 139 & $856 \mathrm{~B}$ & $03 \mathrm{H}$ & $\mathrm{CC}$ & 28 & 31 & 21.33 & 200 & 8 \\
\hline 139 & $856 \mathrm{~B}$ & $04 \mathrm{H}$ & 1 & 78 & 81 & 21.58 & 250 & 10 \\
\hline 139 & $856 \mathrm{~B}$ & $04 \mathrm{H}$ & 1 & 134 & 136 & 22.14 & 120 & 8 \\
\hline 139 & $856 \mathrm{~B}$ & $04 \mathrm{H}$ & 1 & 145 & 147 & 22.25 & 110 & 11 \\
\hline 139 & $856 \mathrm{~B}$ & $04 \mathrm{H}$ & 2 & 86 & 88 & 23.16 & 460 & 2 \\
\hline 139 & $856 \mathrm{~B}$ & $04 \mathrm{H}$ & 2 & 130 & 132 & 23.60 & 300 & 4 \\
\hline 139 & $856 \mathrm{~B}$ & $04 \mathrm{H}$ & 3 & 35 & 37 & 24.15 & 350 & 7 \\
\hline 139 & $856 \mathrm{~B}$ & $04 \mathrm{H}$ & 3 & 85 & 87 & 24.65 & 1500 & 1 \\
\hline 139 & $856 \mathrm{~B}$ & $04 \mathrm{H}$ & 4 & 37 & 39 & 25.67 & 560 & 1 \\
\hline 139 & $856 \mathrm{~B}$ & $04 \mathrm{H}$ & 4 & 101 & 106 & 26.31 & 630 & 1 \\
\hline 139 & $856 \mathrm{~B}$ & $04 \mathrm{H}$ & 6 & 61 & 66 & 28.91 & 710 & 1 \\
\hline 139 & $856 \mathrm{~B}$ & $05 \mathrm{H}$ & 2 & 67 & 70 & 32.47 & 610 & 1 \\
\hline 139 & $856 \mathrm{~B}$ & $05 \mathrm{H}$ & 2 & 73 & 77 & 32.53 & 647 & ND \\
\hline 139 & $856 \mathrm{~B}$ & $05 \mathrm{H}$ & 4 & 51 & 57 & 35.31 & 740 & 1 \\
\hline 139 & $856 \mathrm{~B}$ & $05 \mathrm{H}$ & 6 & 92 & 97 & 38.72 & 610 & ND \\
\hline 139 & $856 \mathrm{~B}$ & $06 \mathrm{H}$ & 2 & 23 & 29 & 41.53 & 630 & 1 \\
\hline 139 & $856 \mathrm{~B}$ & $06 \mathrm{H}$ & 2 & 104 & 108 & 42.34 & 680 & $i$ \\
\hline 139 & $856 \mathrm{~B}$ & $06 \mathrm{H}$ & 4 & 25 & 29 & 44.55 & 750 & 1 \\
\hline 139 & $856 \mathrm{~B}$ & $06 \mathrm{H}$ & 4 & 124 & 128 & 45.54 & 490 & 1 \\
\hline 139 & $856 \mathrm{~B}$ & $06 \mathrm{H}$ & 6 & 12 & 16 & 47.42 & 560 & 1 \\
\hline 139 & $856 \mathrm{~B}$ & $06 \mathrm{H}$ & 6 & 118 & 122 & 48.48 & 530 & 1 \\
\hline 139 & $856 \mathrm{~B}$ & $06 \mathrm{H}$ & 6 & 130 & 132 & 48.60 & 759 & ND \\
\hline 139 & $856 \mathrm{~B}$ & $07 \mathrm{H}$ & 3 & 130 & 133 & 53.60 & 847 & ND \\
\hline 139 & $856 \mathrm{~B}$ & $07 \mathrm{H}$ & 4 & 88 & 95 & 54.68 & 670 & 1 \\
\hline 139 & $856 \mathrm{~B}$ & $07 \mathrm{H}$ & 5 & 26 & 32 & 55.56 & 990 & 1 \\
\hline 139 & $856 \mathrm{~B}$ & $07 \mathrm{H}$ & 6 & 141 & 148 & 58.21 & 810 & 1 \\
\hline 139 & $856 \mathrm{~B}$ & $08 \mathrm{H}$ & 1 & 34 & 36 & 59.14 & 270 & 1 \\
\hline 139 & $856 \mathrm{~B}$ & $08 \mathrm{H}$ & 2 & 55 & 57 & 60.85 & 326 & ND \\
\hline 139 & $856 \mathrm{~B}$ & $08 \mathrm{H}$ & 3 & 55 & 57 & 62.35 & 330 & 1 \\
\hline 139 & $856 \mathrm{~B}$ & $09 \mathrm{X}$ & 2 & 15 & 19 & 63.95 & 270 & 1 \\
\hline 139 & $856 \mathrm{~B}$ & $09 \mathrm{X}$ & 2 & 139 & 142 & 65.19 & 232 & ND \\
\hline 139 & $856 \mathrm{~B}$ & $10 \mathrm{x}$ & 2 & 54 & 58 & 72.84 & 180 & 1 \\
\hline 139 & $856 \mathrm{~B}$ & $11 X$ & 1 & 54 & 58 & 73.84 & 140 & 1 \\
\hline 139 & $856 \mathrm{~B}$ & $11 X$ & 3 & 93 & 97 & 77.23 & 150 & 1 \\
\hline 139 & $856 \mathrm{~B}$ & $11 x$ & 5 & 53 & 57 & 79.83 & 180 & 1 \\
\hline 139 & $856 \mathrm{~B}$ & $12 \mathrm{X}$ & 2 & 42 & 46 & 83.52 & 130 & 1 \\
\hline 139 & $856 \mathrm{~B}$ & $12 \mathrm{X}$ & 2 & 52 & 56 & 83.64 & 0 & ND \\
\hline 139 & $856 \mathrm{~B}$ & $12 X$ & 3 & 12 & 16 & 84.72 & 80 & ND \\
\hline 139 & $856 \mathrm{~B}$ & $12 \mathrm{X}$ & 4 & 29 & 33 & 86.39 & 130 & 1 \\
\hline 139 & $856 \mathrm{~B}$ & $12 \mathrm{X}$ & $\mathrm{CC}$ & 18 & 22 & 89.30 & 100 & 1 \\
\hline 139 & $856 \mathrm{~B}$ & $13 X$ & 2 & 63 & 67 & 93.23 & 100 & 1 \\
\hline 139 & $856 \mathrm{~B}$ & $13 X$ & 4 & 109 & 113 & 96.69 & 111 & ND \\
\hline 139 & $856 \mathrm{~B}$ & $13 X$ & 4 & 128 & 132 & 96.88 & 150 & ND \\
\hline 139 & $856 \mathrm{~B}$ & $14 \mathrm{X}$ & 1 & 34 & 36 & 101.14 & 300 & 1 \\
\hline 139 & $856 \mathrm{~B}$ & $14 \mathrm{X}$ & 3 & 76 & 79 & 104.56 & 100 & 1 \\
\hline 139 & $856 \mathrm{~B}$ & $14 \mathrm{X}$ & 4 & 50 & 53 & 105.80 & 60 & 1 \\
\hline 139 & $856 \mathrm{~B}$ & $15 X$ & 1 & 48 & 50 & 110.88 & 460 & 2 \\
\hline 139 & $856 \mathrm{~B}$ & $15 \mathrm{X}$ & $i$ & 91 & 93 & 111.31 & 440 & 3 \\
\hline 139 & $856 \mathrm{~B}$ & $15 X$ & 1 & 124 & 126 & 111.64 & 30 & 3 \\
\hline 139 & $856 \mathrm{~B}$ & $15 \mathrm{X}$ & 2 & 27 & 29 & 112.17 & 510 & 1 \\
\hline 139 & $856 \mathrm{~B}$ & $15 x$ & 2 & 67 & 69 & 112.57 & 570 & 1 \\
\hline 139 & $856 \mathrm{~B}$ & $15 \mathrm{X}$ & 2 & 100 & 102 & 112.90 & 470 & 1 \\
\hline 139 & $856 \mathrm{~B}$ & $15 \mathrm{X}$ & 3 & 8 & 10 & 113.48 & 290 & 2 \\
\hline 139 & $856 \mathrm{~B}$ & $15 \mathrm{X}$ & 3 & 75 & 77 & 114.15 & 530 & 1 \\
\hline 139 & $856 \mathrm{~B}$ & $15 \mathrm{X}$ & 3 & 104 & 106 & 114.45 & 801 & ND \\
\hline
\end{tabular}


Table 1 (continued).

\begin{tabular}{|c|c|c|c|c|c|c|c|c|}
\hline $\mathrm{Ni}$ & $\mathrm{Pb}$ & $\mathrm{Rb}$ & Sc & $\mathrm{Sr}$ & V & $\mathrm{Y}$ & $\mathrm{Yb}$ & $\mathrm{Zn}$ \\
\hline & & & & & & & $\mathrm{s}$ per mil & lion \\
\hline 48 & 20 & 40 & 10 & 280 & 66 & 26 & 2.30 & 56 \\
\hline 66 & 10 & 60 & 18 & 280 & 140 & 20 & 1.90 & 120 \\
\hline 42 & ND & 61 & ND & 228 & 150 & 22 & ND & 89 \\
\hline 50 & 24 & 75 & 15 & 240 & 120 & 17 & 1.80 & 120 \\
\hline 85 & 36 & 32 & 8.4 & 250 & 56 & 20 & 1.70 & 89 \\
\hline 31 & 10 & 39 & 9.5 & 240 & 64 & 27 & 2.00 & 120 \\
\hline 60 & 20 & 64 & 18 & 270 & 140 & 20 & 2.00 & 120 \\
\hline 51 & 10 & 49 & 19 & 290 & 140 & 20 & 1.80 & 110 \\
\hline 42 & ND & 36 & ND & 324 & 136 & 22 & ND & 53 \\
\hline 44 & 10 & 42 & 17 & 300 & 130 & 44 & 2.60 & 100 \\
\hline 34 & 10 & 33 & 16 & 450 & 120 & 22 & 1.80 & 74 \\
\hline 35 & ND & 40 & 14 & 410 & 92 & 21 & 2.00 & 87 \\
\hline 28 & ND & 39 & ND & 386 & 124 & 18 & ND & 34 \\
\hline 49 & 10 & 60 & 18 & 260 & 130 & 18 & 1.70 & 100 \\
\hline 48 & ND & 51 & ND & 168 & 166 & 20 & ND & 108 \\
\hline 47 & 10 & 46 & 17 & 220 & 120 & 23 & 1.80 & 110 \\
\hline 44 & 10 & 49 & 17 & 240 & 120 & 21 & 2.00 & 77 \\
\hline 38 & 10 & 34 & 16 & 250 & 100 & 18 & 1.60 & 81 \\
\hline 56 & ND & 59 & ND & 120 & 176 & 27 & ND & 110 \\
\hline 44 & 10 & 32 & 15 & 230 & 110 & 17 & 1.60 & 76 \\
\hline 52 & 10 & 63 & 17 & 400 & 130 & 20 & 2.00 & 100 \\
\hline 57 & ND & 92 & ND & 338 & 136 & 19 & ND & 117 \\
\hline 49 & 10 & 68 & 12 & 380 & 82 & 17 & 1.60 & 180 \\
\hline 48 & ND & 70 & ND & 284 & 182 & 24 & ND & 74 \\
\hline 61 & 10 & 53 & 17 & 290 & 140 & 19 & 1.90 & 75 \\
\hline 66 & 10 & 27 & 18 & 270 & 140 & 20 & 1.90 & 97 \\
\hline 5 & 120 & ND & 0.7 & 10 & 2.5 & 2.5 & 0.25 & 18000 \\
\hline 21 & 110 & ND & 4.2 & 28 & 37 & 2.5 & 0.25 & 8000 \\
\hline 17 & 120 & ND & 3.8 & 10 & 46 & 2.5 & 0.25 & 12000 \\
\hline 15 & 140 & ND & 2.5 & 10 & 14 & 2.5 & 0.25 & 11000 \\
\hline 19 & 190 & ND & 2.7 & 20 & 68 & 2.5 & 0.25 & 14000 \\
\hline 20 & 280 & ND & 3.2 & 10 & 88 & 2.5 & 0.25 & 15000 \\
\hline 25 & 240 & ND & 5.3 & 10 & 110 & 2.5 & 0.25 & 16000 \\
\hline 31 & 160 & ND & 8.3 & 31 & 150 & 8 & 0.25 & 11000 \\
\hline 43 & 290 & ND & 8 & 43 & 140 & 14 & 0.25 & 13000 \\
\hline 49 & 190 & ND & 8.7 & 22 & 110 & 7 & 0.25 & 9500 \\
\hline 43 & 250 & ND & 6.7 & 10 & 130 & 2.5 & 0.25 & 11000 \\
\hline 86 & 29 & 64 & 18 & 190 & 160 & 20 & 2.20 & 870 \\
\hline 63 & 55 & ND & 16 & 91 & 160 & 16 & 1.40 & 1900 \\
\hline 68 & 120 & ND & 13 & 70 & 210 & 11 & 1.10 & 5300 \\
\hline 37 & 10 & 66 & 19 & 200 & 140 & 19 & 1.80 & 200 \\
\hline 43 & 10 & 47 & 19 & 190 & 150 & 15 & 1.20 & 390 \\
\hline 40 & 20 & 48 & 16 & 260 & 120 & 24 & 1.90 & 90 \\
\hline 59 & 31 & 85 & 18 & 130 & 140 & 13 & 1.20 & 110 \\
\hline 64 & 10 & 74 & 19 & 130 & 150 & 19 & 1.70 & 140 \\
\hline 53 & ND & 70 & ND & 123 & 183 & 28 & ND & 131 \\
\hline 54 & 10 & 72 & 19 & 130 & 160 & 22 & 2.00 & 100 \\
\hline 58 & 0 & 79 & 19 & 98 & 140 & 19 & 1.80 & 120 \\
\hline 61 & 10 & 88 & 19 & 77 & 140 & 16 & 1.70 & 110 \\
\hline 56 & 10 & 91 & 18 & 78 & 130 & 14 & 1.40 & 120 \\
\hline 50 & 10 & 81 & 18 & 81 & 140 & 24 & 2.00 & 120 \\
\hline 61 & 10 & 80 & 19 & 76 & 140 & 20 & 1.80 & 150 \\
\hline 49 & 10 & 77 & 17 & 80 & 120 & 20 & 1.80 & 86 \\
\hline 62 & 10 & 83 & 19 & 62 & 140 & 19 & 1.70 & 130 \\
\hline 64 & ND & 87 & ND & 52 & 191 & 22 & ND & 391 \\
\hline 39 & ND & 68 & ND & 55 & 170 & 24 & ND & 63 \\
\hline 47 & 10 & 78 & 14 & 59 & 110 & 18 & ND & 77 \\
\hline 39 & 10 & 74 & 15 & 48 & 110 & 18 & 1.60 & 62 \\
\hline 57 & 10 & 63 & 18 & 55 & 140 & 18 & 1.60 & 94 \\
\hline 62 & 39 & 0 & 11 & 34 & 68 & 9 & 0.25 & 33 \\
\hline 31 & ND & 44 & ND & 65 & 133 & 17 & ND & 34 \\
\hline 65 & 10 & 66 & 21 & 43 & 170 & 17 & 1.60 & 82 \\
\hline 49 & 10 & 48 & 18 & 53 & 140 & 23 & 1.80 & 82 \\
\hline 52 & ND & 50 & ND & 45 & 187 & 21 & ND & 115 \\
\hline 35 & 23 & 24 & 17 & 65 & 120 & 20 & 1.90 & 230 \\
\hline 34 & 10 & 30 & 14 & 61 & 90 & 16 & 1.30 & 36 \\
\hline 28 & 10 & 25 & 17 & 66 & 130 & 18 & 1.60 & 71 \\
\hline 36 & 10 & 31 & 16 & 50 & 120 & 14 & 1.20 & 70 \\
\hline 18 & 10 & 18 & 13 & 50 & 100 & 13 & 1.10 & 270 \\
\hline ND & ND & ND & ND & ND & ND & ND & ND & ND \\
\hline 22 & ND & 17 & ND & 58 & 148 & 17 & ND & 117 \\
\hline 25 & 10 & 21 & 16 & 59 & 110 & 16 & 1.40 & 55 \\
\hline 20 & 10 & 18 & 12 & 39 & 88 & 12 & 1.00 & 70 \\
\hline 36 & 10 & 15 & 16 & 44 & 120 & 17 & 1.50 & 67 \\
\hline 35 & ND & 15 & ND & 44 & 127 & 18 & ND & 59 \\
\hline 43 & ND & 23 & 16 & 52 & 120 & 17 & 1.60 & 69 \\
\hline 72 & 150 & 43 & 16 & 10 & 120 & 35 & 2.00 & 99 \\
\hline 89 & 28 & 21 & 16 & 10 & 130 & 15 & 1.10 & 83 \\
\hline 38 & 10 & 15 & 14 & 10 & 100 & 12 & 0.90 & 83 \\
\hline 45 & 10 & 25 & 16 & 10 & 130 & 20 & 1.40 & 130 \\
\hline 39 & 10 & 26 & 15 & 10 & 97 & 16 & 1.10 & 140 \\
\hline 41 & 10 & 5 & 9.2 & 10 & 66 & 12 & 1.10 & 350 \\
\hline 46 & 10 & 25 & 18 & 10 & 130 & 14 & 0.90 & 100 \\
\hline 19 & 10 & 23 & 11 & 10 & 67 & 21 & 1.70 & 200 \\
\hline 27 & 10 & 28 & 15 & 10 & 97 & 13 & 1.00 & 130 \\
\hline 20 & 10 & 17 & 12 & 10 & 74 & 11 & 0.90 & 140 \\
\hline 16 & 10 & 27 & 14 & 10 & 120 & 10 & 0.70 & 110 \\
\hline 64 & ND & 21 & ND & 130 & 311 & 23 & ND & 184 \\
\hline
\end{tabular}


Table 1 (continued).

\begin{tabular}{|c|c|c|c|c|c|c|c|c|}
\hline & & & & Udepth & Ldepth & Depth & & \\
\hline Leg & Hole & Core & Section & $(\mathrm{cm})$ & $(\mathrm{cm})$ & (mbsf) & $\mathrm{Ba}$ & $\mathrm{Ag}$ \\
\hline 139 & $856 \mathrm{~B}$ & $15 \mathrm{X}$ & 3 & 122 & 124 & 114.62 & 220 & 1 \\
\hline 139 & $856 \mathrm{~B}$ & $15 \mathrm{X}$ & 4 & 12 & 14 & 115.02 & 580 & i \\
\hline 139 & $856 \mathrm{~B}$ & $15 x$ & 4 & 70 & 72 & 115.60 & 520 & i \\
\hline 139 & $856 \mathrm{~B}$ & $15 x$ & 4 & 130 & 132 & 116.20 & 470 & 1 \\
\hline 139 & $856 \mathrm{~B}$ & $15 x$ & 5 & 8 & 10 & 116.48 & 850 & 1 \\
\hline 139 & $856 \mathrm{~B}$ & $15 \mathrm{X}$ & 5 & 76 & 78 & 117.16 & 510 & 1 \\
\hline 139 & $856 \mathrm{~B}$ & $15 X$ & 5 & 106 & 108 & 117.46 & 330 & 2 \\
\hline 139 & $856 \mathrm{~B}$ & $15 X$ & 6 & 6 & 8 & 117.96 & 50 & 1 \\
\hline 139 & $856 \mathrm{~B}$ & $15 \mathrm{X}$ & $\mathrm{CC}$ & 20 & 22 & 118.22 & 15 & 2 \\
\hline 139 & 856D & $01 \mathrm{H}$ & 1 & 3 & 6 & 0.03 & 20000 & 8 \\
\hline 139 & 856D & $01 \mathrm{H}$ & 1 & 15 & 18 & 0.15 & 32000 & 10 \\
\hline 139 & $856 \mathrm{D}$ & $01 \mathrm{H}$ & i & 34 & 37 & 0.34 & 79000 & 6 \\
\hline 139 & 856D & $01 \mathrm{H}$ & 1 & 39 & 42 & 0.39 & 37000 & 9 \\
\hline 139 & $856 \mathrm{D}$ & $01 \mathrm{H}$ & 1 & 66 & 69 & 0.66 & 4000 & 4 \\
\hline 139 & $856 \mathrm{D}$ & $01 \mathrm{H}$ & 1 & 89 & 93 & 0.89 & 30 & 3 \\
\hline 139 & 856D & $01 \mathrm{H}$ & 1 & 112 & 115 & 1.12 & 80 & 2 \\
\hline 139 & 856D & $01 \mathrm{H}$ & 1 & 135 & 138 & 1.35 & 5800 & 3 \\
\hline 139 & 856D & $01 \mathrm{H}$ & 2 & 10 & 14 & 1.60 & 840 & 2 \\
\hline 139 & 856D & $01 \mathrm{H}$ & 2 & 43 & 46 & 1.93 & 17000 & 1 \\
\hline 139 & 856D & $01 \mathrm{H}$ & 2 & 57 & 59 & 2.07 & 510 & i \\
\hline 139 & 856D & $01 \mathrm{H}$ & 3 & 16 & 20 & 3.16 & 830 & 2 \\
\hline 139 & 856D & $01 \mathrm{H}$ & 3 & 32 & 36 & 3.32 & 50 & 2 \\
\hline 139 & $856 \mathrm{D}$ & $01 \mathrm{H}$ & 3 & 90 & 94 & 3.90 & 980 & 2 \\
\hline 139 & 856D & $01 \mathrm{H}$ & 3 & 121 & 124 & 4.21 & 80 & 2 \\
\hline 139 & 856D & $01 \mathrm{H}$ & 4 & 25 & 28 & 4.75 & 570 & 3 \\
\hline 139 & 856D & $01 \mathrm{H}$ & 4 & 114 & 116 & 5.64 & 980 & 2 \\
\hline 139 & 856D & $01 \mathrm{H}$ & 4 & 145 & 148 & 5.95 & 860 & 2 \\
\hline 139 & 856D & $01 \mathrm{H}$ & 5 & 54 & 57 & 6.54 & 1000 & 1 \\
\hline 139 & $856 \mathrm{D}$ & $01 \mathrm{H}$ & 5 & 66 & 69 & 6.66 & 780 & 1 \\
\hline 139 & $856 \mathrm{D}$ & $01 \mathrm{H}$ & 5 & 88 & 91 & 6.88 & 30 & i \\
\hline 139 & $856 \mathrm{D}$ & $01 \mathrm{H}$ & 7 & 46 & 48 & 7.89 & 10000 & 3 \\
\hline 139 & 856D & $01 \mathrm{H}$ & 7 & 70 & 71 & 8.13 & 12000 & 3 \\
\hline 139 & $856 \mathrm{E}$ & $01 \mathrm{H}$ & 1 & 48 & 50 & 0.48 & 18000 & 10 \\
\hline 139 & $856 \mathrm{E}$ & $\mathrm{OlH}$ & 1 & 73 & 75 & 0.73 & 4500 & 1 \\
\hline 139 & $856 \mathrm{E}$ & $01 \mathrm{H}$ & 1 & 90 & 92 & 0.90 & 9100 & 3 \\
\hline 139 & $856 \mathrm{E}$ & $01 \mathrm{H}$ & 1 & 96 & 98 & 0.96 & 18000 & 48 \\
\hline 139 & $856 \mathrm{E}$ & $01 \mathrm{H}$ & 1 & 129 & 131 & 1.29 & 88000 & 7 \\
\hline 139 & $856 \mathrm{E}$ & $01 \mathrm{H}$ & 2 & 55 & 57 & 2.05 & 47000 & 5 \\
\hline 139 & $856 \mathrm{~F}$ & $02 \mathrm{X}$ & CC & 23 & 25 & 11.93 & 120 & 1 \\
\hline 139 & $856 \mathrm{G}$ & $01 R$ & 3 & 84 & 86 & 3.84 & 2700 & 3 \\
\hline 139 & $856 \mathrm{G}$ & OIR & 3 & 112 & 114 & 4.12 & 2400 & 5 \\
\hline 139 & $856 \mathrm{G}$ & $02 R$ & 2 & 54 & 56 & 10.64 & 1600 & 1 \\
\hline 139 & $856 \mathrm{G}$ & $03 R$ & 1 & 12 & 14 & 17.72 & 15 & 6 \\
\hline 139 & $856 \mathrm{G}$ & $03 \mathrm{R}$ & 1 & 30 & 32 & 17.90 & 110 & 1 \\
\hline 139 & $856 \mathrm{G}$ & $03 R$ & 1 & 35 & 37 & 17.95 & 100 & 1 \\
\hline 139 & $856 \mathrm{G}$ & $03 R$ & 1 & 81 & 84 & 18.41 & 50 & 1 \\
\hline 139 & $856 \mathrm{G}$ & $04 \mathrm{R}$ & 1 & 83 & 85 & 27.83 & 50 & i \\
\hline 139 & $856 \mathrm{G}$ & $05 R$ & 1 & 34 & 36 & 37.04 & 100 & 1 \\
\hline 139 & $856 \mathrm{G}$ & $05 \mathrm{R}$ & 1 & 59 & 61 & 37.29 & 140 & 1 \\
\hline 139 & $856 \mathrm{G}$ & $06 \mathrm{R}$ & 1 & 19 & 21 & 46.49 & 60 & 1 \\
\hline 139 & $856 \mathrm{G}$ & $06 \mathrm{R}$ & i & 24 & 28 & 46.54 & 70 & i \\
\hline 139 & $856 \mathrm{G}$ & $06 \mathrm{R}$ & 1 & 71 & 73 & 47.01 & 30 & i \\
\hline 139 & $856 \mathrm{G}$ & $06 \mathrm{R}$ & 2 & 80 & 82 & 48.60 & 160 & 1 \\
\hline 139 & $856 \mathrm{G}$ & $06 \mathrm{R}$ & 2 & 87 & 89 & 48.67 & 70 & 1 \\
\hline 139 & $856 \mathrm{G}$ & $06 \mathrm{R}$ & 3 & 13 & 16 & 49.43 & 30 & 1 \\
\hline 139 & $856 \mathrm{G}$ & $06 \mathrm{R}$ & 3 & 17 & 19 & 49.47 & 80 & i \\
\hline 139 & $856 \mathrm{G}$ & $06 \mathrm{R}$ & 3 & 87 & 89 & 50.17 & 90 & i \\
\hline 139 & $856 \mathrm{G}$ & $06 \mathrm{R}$ & 3 & 129 & 131 & 50.59 & 40 & 4 \\
\hline 139 & $856 \mathrm{G}$ & $06 \mathrm{R}$ & 3 & 132 & 134 & 50.62 & 40 & 1 \\
\hline 139 & $856 \mathrm{G}$ & $07 \mathrm{R}$ & 1 & 1 & 3 & 55.81 & 40 & 1 \\
\hline 139 & $856 \mathrm{G}$ & $07 \mathrm{R}$ & 1 & 21 & 23 & 56.01 & 90 & 11 \\
\hline 139 & $856 \mathrm{G}$ & $07 \mathrm{R}$ & i & 42 & 43 & 56.22 & 15 & 9 \\
\hline 139 & $856 \mathrm{G}$ & $07 \mathrm{R}$ & 1 & 46 & 47 & 56.26 & 50 & 4 \\
\hline 139 & $856 \mathrm{G}$ & $07 \mathrm{R}$ & 2 & 46 & 48 & 57.66 & 60 & 3 \\
\hline 139 & $856 \mathrm{G}$ & $07 \mathrm{R}$ & 2 & 120 & 122 & 58.40 & 40 & i \\
\hline 139 & $856 \mathrm{G}$ & $07 \mathrm{R}$ & 3 & 103 & 106 & 59.72 & 40 & 4 \\
\hline 139 & $856 \mathrm{G}$ & $07 \mathrm{R}$ & 3 & 103 & 106 & 59.72 & 60 & 5 \\
\hline 139 & $856 \mathrm{G}$ & $07 \mathrm{R}$ & 3 & 123 & 125 & 59.92 & 90 & 1 \\
\hline 139 & $856 \mathrm{G}$ & $07 \mathrm{R}$ & 4 & 35 & 37 & 60.45 & 60 & 1 \\
\hline 139 & $856 \mathrm{H}$ & $03 R$ & 1 & 28 & 30 & 22.38 & 2900 & i \\
\hline 139 & $856 \mathrm{H}$ & $03 R$ & 1 & 38 & 40 & 22.48 & 270 & 1 \\
\hline 139 & $856 \mathrm{H}$ & $03 R$ & i & 60 & 62 & 22.70 & 70 & 1 \\
\hline 139 & $856 \mathrm{H}$ & $03 R$ & 1 & 75 & 77 & 24.01 & 230 & 1 \\
\hline 139 & $856 \mathrm{H}$ & $03 R$ & 2 & 16 & 18 & 23.42 & 110 & i \\
\hline 139 & $856 \mathrm{H}$ & $03 R$ & 2 & 84 & 87 & 24.10 & 40 & i \\
\hline 139 & $856 \mathrm{H}$ & $03 R$ & 2 & 135 & 138 & 24.61 & 40 & 1 \\
\hline 139 & $856 \mathrm{H}$ & $03 R$ & 3 & 17 & 19 & 24.88 & 40 & 1 \\
\hline 139 & $856 \mathrm{H}$ & $03 R$ & 3 & 72 & 74 & 25.43 & 40 & i \\
\hline 139 & $856 \mathrm{H}$ & $04 \mathrm{R}$ & 1 & 21 & 23 & 26.81 & 15 & $i$ \\
\hline 139 & $856 \mathrm{H}$ & $04 \mathrm{R}$ & i & 65 & 67 & 27.25 & 30 & i \\
\hline 139 & $856 \mathrm{H}$ & $04 \mathrm{R}$ & 1 & 88 & 90 & 27.48 & 15 & 1 \\
\hline 139 & $856 \mathrm{H}$ & $04 R$ & i & 124 & 126 & 27.84 & 40 & 7 \\
\hline 139 & $856 \mathrm{H}$ & $04 R$ & 1 & 135 & 137 & 27.95 & 110 & 1 \\
\hline 139 & $856 \mathrm{H}$ & $04 \mathrm{R}$ & 2 & 6 & 8 & 28.16 & 50 & 1 \\
\hline 139 & $856 \mathrm{H}$ & $04 R$ & 2 & 17 & 19 & 28.27 & 40 & 2 \\
\hline 139 & $856 \mathrm{H}$ & $04 R$ & 2 & 43 & 45 & 28.53 & 40 & 1 \\
\hline 139 & $856 \mathrm{H}$ & $04 R$ & 2 & 96 & 98 & 29.06 & 180 & 1 \\
\hline 139 & $856 \mathrm{H}$ & $04 \mathrm{R}$ & 2 & 131 & 133 & 29.41 & 70 & 1 \\
\hline
\end{tabular}


Table 1 (continued).

\begin{tabular}{|c|c|c|c|c|c|c|c|c|}
\hline $\mathrm{Ni}$ & $\mathrm{Pb}$ & $\mathrm{Rb}$ & $\mathrm{Sc}$ & $\mathrm{Sr}$ & V & $\mathrm{Y}$ & $\mathrm{Yb}$ & $\mathrm{Zn}$ \\
\hline & & & & & & & per mil & illion \\
\hline 23 & 10 & 12 & 11 & 10 & 68 & 20 & 1.50 & 92 \\
\hline 22 & 10 & 28 & 15 & 38 & 64 & 12 & 1.10 & 81 \\
\hline 47 & 10 & 30 & 18 & 23 & 140 & 15 & 1.20 & 88 \\
\hline 40 & 10 & ND & 18 & 330 & 160 & 25 & 1.90 & 590 \\
\hline 48 & 10 & 42 & 25 & 44 & 120 & 27 & 2.10 & 76 \\
\hline 35 & 10 & 19 & 14 & 130 & 91 & 19 & 1.70 & 64 \\
\hline 26 & 10 & 12 & 12 & 54 & 73 & 14 & 1.10 & 64 \\
\hline 5 & 10 & 5 & 15 & 90 & 18 & 16 & 1.90 & 2.5 \\
\hline 31 & 10 & ND & 10 & 65 & 38 & 10 & 0.90 & 110 \\
\hline 5 & 120 & ND & 0.7 & 360 & 2.5 & 2.5 & 0.25 & 2800 \\
\hline 5 & 120 & ND & 0.7 & 380 & 9 & 2.5 & 0.25 & 3700 \\
\hline 5 & 31 & ND & 0.6 & 490 & 12 & 2.5 & 0.90 & 2200 \\
\hline 5 & 160 & ND & 0.7 & 500 & 2.5 & 2.5 & 0.25 & 1500 \\
\hline 5 & 140 & ND & 0.3 & 94 & 2.5 & 2.5 & 0.25 & 27000 \\
\hline 13 & 120 & ND & 0.3 & 10 & 2.5 & 2.5 & 0.25 & 28000 \\
\hline 11 & 100 & ND & 0.3 & 10 & 2.5 & 2.5 & 0.25 & 31000 \\
\hline 5 & 45 & ND & 0.3 & 140 & 2.5 & 2.5 & 0.25 & 26000 \\
\hline 5 & 44 & ND & 0.3 & 27 & 2.5 & 2.5 & 0.25 & 36000 \\
\hline 5 & 10 & ND & 0.3 & 410 & 2.5 & 2.5 & 0.25 & 20000 \\
\hline 5 & 24 & ND & 0.3 & 10 & 2.5 & 2.5 & 0.25 & 14000 \\
\hline 5 & 33 & ND & 0.3 & 36 & 2.5 & 2.5 & 0.25 & 40000 \\
\hline 11 & 34 & ND & 0.3 & 10 & 2.5 & 2.5 & 0.25 & 48000 \\
\hline 5 & 39 & ND & 0.3 & 30 & 2.5 & 2.5 & 0.25 & 37000 \\
\hline 10 & 56 & ND & 0.3 & 10 & 2.5 & 2.5 & 0.25 & 37000 \\
\hline 5 & 53 & ND & 0.3 & 22 & 2.5 & 5 & 0.25 & 36000 \\
\hline 5 & 60 & ND & 0.3 & 31 & 2.5 & 2.5 & 0.25 & 37000 \\
\hline 5 & 33 & ND & 0.3 & 22 & 2.5 & 2.5 & 0.25 & 40000 \\
\hline 5 & 38 & ND & 0.3 & 35 & 2.5 & 2.5 & 0.25 & 44000 \\
\hline 5 & 32 & ND & 0.3 & 34 & 2.5 & 2.5 & 0.25 & 79000 \\
\hline 5 & 10 & ND & ND & 10 & 2.5 & 2.5 & 0.25 & 22000 \\
\hline 5 & 47 & ND & 0.5 & 370 & 2.5 & 2.5 & 0.25 & 62000 \\
\hline 5 & 39 & ND & 0.3 & 360 & 2.5 & 2.5 & 0.25 & 41000 \\
\hline 5 & 430 & ND & 10 & 550 & 380 & 12 & 0.90 & 44000 \\
\hline 5 & 180 & 56 & 13 & 340 & 170 & 23 & 1.40 & 5500 \\
\hline 5 & 230 & ND & 14 & 480 & 180 & 18 & 1.40 & 11000 \\
\hline 5 & 1500 & ND & 6.9 & 460 & 290 & 7 & 0.25 & 61000 \\
\hline 5 & 51 & ND & 0.7 & 470 & 49 & 2.5 & 1.40 & 23000 \\
\hline 5 & 25 & ND & 0.7 & 360 & 12 & 2.5 & 2.40 & 11000 \\
\hline 5 & 10 & ND & 0.3 & 21 & 2.5 & 2.5 & 0.25 & 20000 \\
\hline 5 & 140 & ND & 0.8 & 84 & 2.5 & 2.5 & 0.25 & 780 \\
\hline 5 & 200 & ND & 0.8 & 89 & 2.5 & 2.5 & 0.25 & 1000 \\
\hline 5 & 10 & ND & 0.3 & 45 & 2.5 & 2.5 & 0.25 & 3500 \\
\hline 5 & 35 & ND & 0.6 & 10 & 2.5 & 2.5 & 0.25 & 4800 \\
\hline 5 & 21 & ND & ND & 10 & 2.5 & 2.5 & 0.25 & 15000 \\
\hline 5 & 10 & ND & 1.2 & 10 & 2.5 & 2.5 & 0.25 & 7300 \\
\hline 12 & 23 & ND & 1.5 & 10 & 2.5 & 2.5 & 0.25 & 2800 \\
\hline 5 & 29 & ND & 1 & 10 & 2.5 & 2.5 & 0.25 & 1200 \\
\hline 5 & 10 & ND & 1.2 & 10 & 2.5 & 2.5 & 0.25 & 94 \\
\hline 5 & 10 & ND & 0.7 & 26 & 2.5 & 2.5 & 0.25 & 43 \\
\hline 5 & 78 & ND & 0.7 & 10 & 2.5 & 2.5 & 0.25 & 4000 \\
\hline 5 & 65 & ND & 0.8 & 10 & 2.5 & 2.5 & 0.25 & 570 \\
\hline 16 & 24 & ND & 0.7 & 10 & 2.5 & 2.5 & 0.25 & 82 \\
\hline 5 & 51 & ND & 0.8 & 10 & 2.5 & 2.5 & 0.25 & 61 \\
\hline 13 & 50 & ND & 0.7 & 10 & 2.5 & 2.5 & 0.25 & 380 \\
\hline 5 & 57 & ND & 0.7 & 10 & 2.5 & 2.5 & 0.25 & 150 \\
\hline 5 & 43 & ND & 0.7 & 10 & 2.5 & 2.5 & 0.25 & 26 \\
\hline 11 & 26 & ND & 0.6 & 10 & 2.5 & 2.5 & 0.25 & 4600 \\
\hline 5 & 38 & ND & 0.6 & 10 & 2.5 & 2.5 & 0.25 & 2400 \\
\hline 12 & 21 & ND & 0.5 & 10 & 2.5 & 2.5 & 0.25 & 49 \\
\hline 10 & 20 & ND & 0.7 & 10 & 2.5 & 2.5 & 0.25 & 96 \\
\hline 5 & 46 & ND & 0.7 & 10 & 2.5 & 2.5 & 0.25 & 92 \\
\hline 36 & 260 & ND & 0.3 & 10 & 2.5 & 2.5 & 0.80 & 13000 \\
\hline 5 & 55 & ND & 1.1 & 10 & 2.5 & 2.5 & 0.25 & 1500 \\
\hline 5 & 43 & ND & 1.1 & 10 & 2.5 & 2.5 & 0.25 & 150 \\
\hline 17 & 74 & ND & 0.3 & 10 & 2.5 & 2.5 & 0.25 & 42000 \\
\hline 5 & 93 & ND & 0.9 & 10 & 2.5 & 2.5 & 0.25 & 250 \\
\hline 5 & 52 & ND & 0.9 & 10 & 2.5 & 2.5 & 0.25 & 4900 \\
\hline 5 & 130 & ND & 0.8 & 10 & 2.5 & 2.5 & 0.25 & 32000 \\
\hline 5 & 100 & ND & 0.8 & 10 & 2.5 & 2.5 & 0.25 & 17000 \\
\hline 5 & 10 & ND & 0.7 & 78 & 2.5 & 2.5 & 0.25 & 49000 \\
\hline 5 & 23 & ND & 0.9 & 10 & 2.5 & 2.5 & 0.25 & 40000 \\
\hline 5 & 29 & ND & 0.9 & 10 & 2.5 & 2.5 & 0.00 & 24000 \\
\hline 5 & 22 & ND & 0.9 & 23 & 2.5 & 2.5 & 0.25 & 63000 \\
\hline 5 & 20 & ND & 0.8 & 26 & 2.5 & 2.5 & 0.25 & 34000 \\
\hline 10 & 10 & ND & 0.7 & 21 & 2.5 & 2.5 & 0.25 & 60000 \\
\hline 5 & 23 & ND & 0.8 & 10 & 2.5 & 2.5 & 0.25 & 35000 \\
\hline 5 & 28 & ND & 0.7 & 10 & 2.5 & 2.5 & 0.25 & 27000 \\
\hline 5 & 23 & ND & 2 & 10 & 2.5 & 2.5 & 0.25 & 7300 \\
\hline 15 & 10 & ND & 4.4 & 10 & 14 & 2.5 & 0.25 & 23000 \\
\hline 5 & 10 & ND & 2.7 & 10 & 19 & 2.5 & 0.25 & 35000 \\
\hline 12 & 10 & ND & 1.4 & 10 & 10 & 2.5 & 0.25 & 23000 \\
\hline 5 & 20 & ND & 1.1 & 10 & 20 & 2.5 & 0.25 & 12000 \\
\hline 5 & 28 & ND & 0.8 & 10 & 2.2 & 2.5 & 0.25 & 12000 \\
\hline 5 & 10 & ND & 1.5 & 10 & 2.5 & 2.5 & 0.25 & 59000 \\
\hline 5 & 10 & ND & 1.1 & 10 & 14 & 2.5 & 0.25 & 1400 \\
\hline 5 & 10 & ND & 1.6 & 10 & 7 & 2.5 & 0.25 & 76000 \\
\hline 5 & 10 & ND & 1.5 & 10 & 2.5 & 2.5 & 0.25 & 23000 \\
\hline 5 & 10 & ND & 1 & 10 & 2.5 & 2.5 & 0.25 & 2900 \\
\hline
\end{tabular}


Table 1 (continued).

\begin{tabular}{|c|c|c|c|c|c|}
\hline & & & & Udepth & Ldepth \\
\hline Leg & Hole & Core & Section & $(\mathrm{cm})$ & $(\mathrm{cm})$ \\
\hline 139 & $856 \mathrm{H}$ & $04 \mathrm{R}$ & 3 & 16 & 17 \\
\hline 139 & $856 \mathrm{H}$ & $06 \mathrm{R}$ & 1 & 39 & 41 \\
\hline 139 & $856 \mathrm{H}$ & $07 \mathrm{R}$ & i & 38 & 40 \\
\hline 139 & $856 \mathrm{H}$ & $07 \mathrm{R}$ & 1 & 45 & 47 \\
\hline 139 & $856 \mathrm{H}$ & $08 \mathrm{R}$ & 1 & 28 & 30 \\
\hline 139 & $856 \mathrm{H}$ & $08 \mathrm{R}$ & i & 23 & 25 \\
\hline 139 & $856 \mathrm{H}$ & $08 R$ & 1 & 72 & 74 \\
\hline 139 & $856 \mathrm{H}$ & $08 \mathrm{R}$ & i & 118 & 121 \\
\hline 139 & $856 \mathrm{H}$ & $09 \mathrm{R}$ & 1 & 68 & 70 \\
\hline 139 & $856 \mathrm{H}$ & $09 \mathrm{R}$ & 1 & 80 & 82 \\
\hline 139 & $856 \mathrm{H}$ & $10 \mathrm{R}$ & i & 20 & 22 \\
\hline 139 & $856 \mathrm{H}$ & $11 \mathrm{R}$ & i & 25 & 27 \\
\hline 139 & $856 \mathrm{H}$ & $11 \mathrm{R}$ & i & 91 & 93 \\
\hline 139 & $856 \mathrm{H}$ & $11 \mathrm{R}$ & i & 108 & 110 \\
\hline 139 & $856 \mathrm{H}$ & IIR & i & 114 & 117 \\
\hline 139 & $856 \mathrm{H}$ & $13 R$ & 1 & 43 & 46 \\
\hline 139 & $856 \mathrm{H}$ & $14 R$ & i & 16 & 18 \\
\hline 139 & $856 \mathrm{H}$ & $14 \mathrm{R}$ & i & 28 & 30 \\
\hline 139 & $856 \mathrm{H}$ & $14 R$ & i & 84 & 86 \\
\hline 139 & $856 \mathrm{H}$ & $14 \mathrm{R}$ & 1 & 108 & 110 \\
\hline 139 & $856 \mathrm{H}$ & $15 R$ & i & 73 & 76 \\
\hline 139 & $856 \mathrm{H}$ & $15 \mathrm{R}$ & 1 & 74 & 76 \\
\hline 139 & $856 \mathrm{H}$ & $15 R$ & 1 & 118 & 120 \\
\hline 139 & $856 \mathrm{H}$ & $16 \mathrm{R}$ & $i$ & 27 & 29 \\
\hline 139 & $856 \mathrm{H}$ & $16 R$ & i & 53 & 55 \\
\hline 139 & $857 \mathrm{~A}$ & $01 \mathrm{H}$ & 2 & 80 & 84 \\
\hline 139 & $857 \mathrm{~A}$ & $01 \mathrm{H}$ & 2 & 90 & 94 \\
\hline 139 & $857 \mathrm{~A}$ & $01 \mathrm{H}$ & 4 & 46 & 50 \\
\hline 139 & $857 \mathrm{~A}$ & $\mathrm{OHH}$ & 6 & 76 & 80 \\
\hline 139 & $857 \mathrm{~A}$ & $02 \mathrm{H}$ & 1 & 126 & 128 \\
\hline 139 & $857 \mathrm{~A}$ & $02 \mathrm{H}$ & 2 & 73 & 75 \\
\hline 139 & $857 \mathrm{~A}$ & $02 \mathrm{H}$ & 3 & 125 & 127 \\
\hline 139 & $857 \mathrm{~A}$ & $02 \mathrm{H}$ & 5 & 126 & 128 \\
\hline 139 & $857 \mathrm{~A}$ & $02 \mathrm{H}$ & 7 & 44 & 46 \\
\hline 139 & $857 \mathrm{~A}$ & $04 \mathrm{H}$ & 2 & 67 & 71 \\
\hline 139 & $857 \mathrm{~A}$ & $04 \mathrm{H}$ & 2 & 86 & 90 \\
\hline 139 & $857 \mathrm{~A}$ & $04 \mathrm{H}$ & 4 & 25 & 29 \\
\hline 139 & $857 \mathrm{~A}$ & $04 \mathrm{H}$ & 6 & 25 & 29 \\
\hline 139 & $857 \mathrm{~A}$ & $05 \mathrm{H}$ & 2 & 27 & 31 \\
\hline 139 & $857 \mathrm{~A}$ & $05 \mathrm{H}$ & 3 & 78 & 82 \\
\hline 139 & $857 \mathrm{~A}$ & $\mathrm{OSH}$ & 4 & 45 & 49 \\
\hline 139 & $857 \mathrm{~A}$ & $05 \mathrm{H}$ & 6 & 54 & 58 \\
\hline 139 & $857 \mathrm{~A}$ & $06 \mathrm{H}$ & 1 & 143 & 147 \\
\hline 139 & $857 \mathrm{~A}$ & $06 \mathrm{H}$ & 3 & 52 & 56 \\
\hline 139 & $857 \mathrm{~A}$ & $06 \mathrm{H}$ & 4 & 54 & 58 \\
\hline 139 & $857 \mathrm{~A}$ & $06 \mathrm{H}$ & 5 & 89 & 93 \\
\hline 139 & $857 \mathrm{~A}$ & $06 \mathrm{H}$ & 7 & 20 & 24 \\
\hline 139 & $857 \mathrm{~A}$ & $07 \mathrm{H}$ & 2 & 22 & 26 \\
\hline 139 & $857 \mathrm{~A}$ & $07 \mathrm{H}$ & 3 & 69 & 73 \\
\hline 139 & $857 \mathrm{~A}$ & $07 \mathrm{H}$ & 3 & 87 & 93 \\
\hline 139 & $857 \mathrm{~A}$ & $07 \mathrm{H}$ & 4 & 64 & 68 \\
\hline 139 & $857 \mathrm{~A}$ & $07 \mathrm{H}$ & 6 & 109 & 113 \\
\hline 139 & $857 \mathrm{~A}$ & $08 \mathrm{H}$ & 2 & 32 & 36 \\
\hline 139 & $857 \mathrm{~A}$ & $08 \mathrm{H}$ & 2 & 95 & 99 \\
\hline 139 & $857 \mathrm{~A}$ & $08 \mathrm{H}$ & 5 & 13 & 17 \\
\hline 139 & $857 \mathrm{~A}$ & $08 \mathrm{H}$ & 5 & 47 & 51 \\
\hline 139 & $857 \mathrm{~A}$ & $08 \mathrm{H}$ & 6 & 61 & 65 \\
\hline 139 & $857 \mathrm{~A}$ & $08 \mathrm{H}$ & 7 & 3 & 7 \\
\hline 139 & $857 \mathrm{~A}$ & $09 \mathrm{H}$ & 2 & 93 & 98 \\
\hline 139 & $857 \mathrm{~A}$ & $\mathrm{OPH}$ & 3 & 40 & 45 \\
\hline 139 & $857 \mathrm{~A}$ & $\mathrm{O} \mathrm{H}$ & 5 & 105 & 109 \\
\hline 139 & $857 \mathrm{~A}$ & $09 \mathrm{H}$ & ND & 53 & 55 \\
\hline 139 & $857 \mathrm{~A}$ & $10 \mathrm{H}$ & 1 & 95 & 97 \\
\hline 139 & $857 \mathrm{~A}$ & $10 \mathrm{H}$ & 2 & 79 & 81 \\
\hline 139 & $857 \mathrm{~A}$ & $10 \mathrm{H}$ & 4 & 77 & 79 \\
\hline 139 & $857 \mathrm{~A}$ & $10 \mathrm{H}$ & 6 & 19 & 21 \\
\hline 139 & $857 \mathrm{~A}$ & $11 X$ & CC & 26 & 28 \\
\hline 139 & $857 \mathrm{~A}$ & $13 X$ & 1 & 25 & 27 \\
\hline 139 & $857 \mathrm{~A}$ & $13 \mathrm{X}$ & 1 & 62 & 63 \\
\hline 139 & $857 \mathrm{~A}$ & $13 x$ & $i$ & 91 & 93 \\
\hline 139 & $857 \mathrm{~A}$ & $13 X$ & i & 136 & 139 \\
\hline 139 & $857 \mathrm{~A}$ & $13 x$ & 3 & 65 & 67 \\
\hline 139 & $857 \mathrm{~A}$ & $13 \mathrm{X}$ & 3 & 122 & 124 \\
\hline 139 & $857 \mathrm{~A}$ & $13 \mathrm{X}$ & CC & 33 & 35 \\
\hline 139 & $857 \mathrm{C}$ & $02 R$ & & 63 & 67 \\
\hline 139 & $857 \mathrm{C}$ & $02 R$ & 2 & 6 & 10 \\
\hline 139 & $857 \mathrm{C}$ & $03 R$ & i & 72 & 74 \\
\hline 139 & $857 \mathrm{C}$ & $03 \mathrm{R}$ & 3 & 38 & 40 \\
\hline 139 & $857 \mathrm{C}$ & $03 R$ & 3 & 110 & 112 \\
\hline 139 & $857 \mathrm{C}$ & $05 R$ & 1 & 4 & 8 \\
\hline $\begin{array}{l}139 \\
\end{array}$ & $857 \mathrm{C}$ & $05 R$ & 1 & 12 & 16 \\
\hline 139 & $857 \mathrm{C}$ & $05 R$ & 4 & 110 & 113 \\
\hline 139 & $857 \mathrm{C}$ & $06 \mathrm{R}$ & 1 & 1 & 2 \\
\hline 139 & $857 \mathrm{C}$ & $06 R$ & i & 33 & 35 \\
\hline 139 & $857 \mathrm{C}$ & $06 R$ & 1 & 66 & 68 \\
\hline 139 & $857 \mathrm{C}$ & $06 \mathrm{R}$ & 2 & 101 & 103 \\
\hline 139 & $857 \mathrm{C}$ & $07 \mathrm{R}$ & CC & 1 & 2 \\
\hline 139 & $857 \mathrm{C}$ & $08 \mathrm{R}$ & CC & 3 & 4 \\
\hline 139 & $857 \mathrm{C}$ & $09 \mathrm{R}$ & 1 & 8 & 9 \\
\hline 139 & $857 \mathrm{C}$ & $09 \mathrm{R}$ & i & 27 & 30 \\
\hline 139 & $857 \mathrm{C}$ & $09 R$ & 1 & 89 & 91 \\
\hline
\end{tabular}


Table 1 (continued).

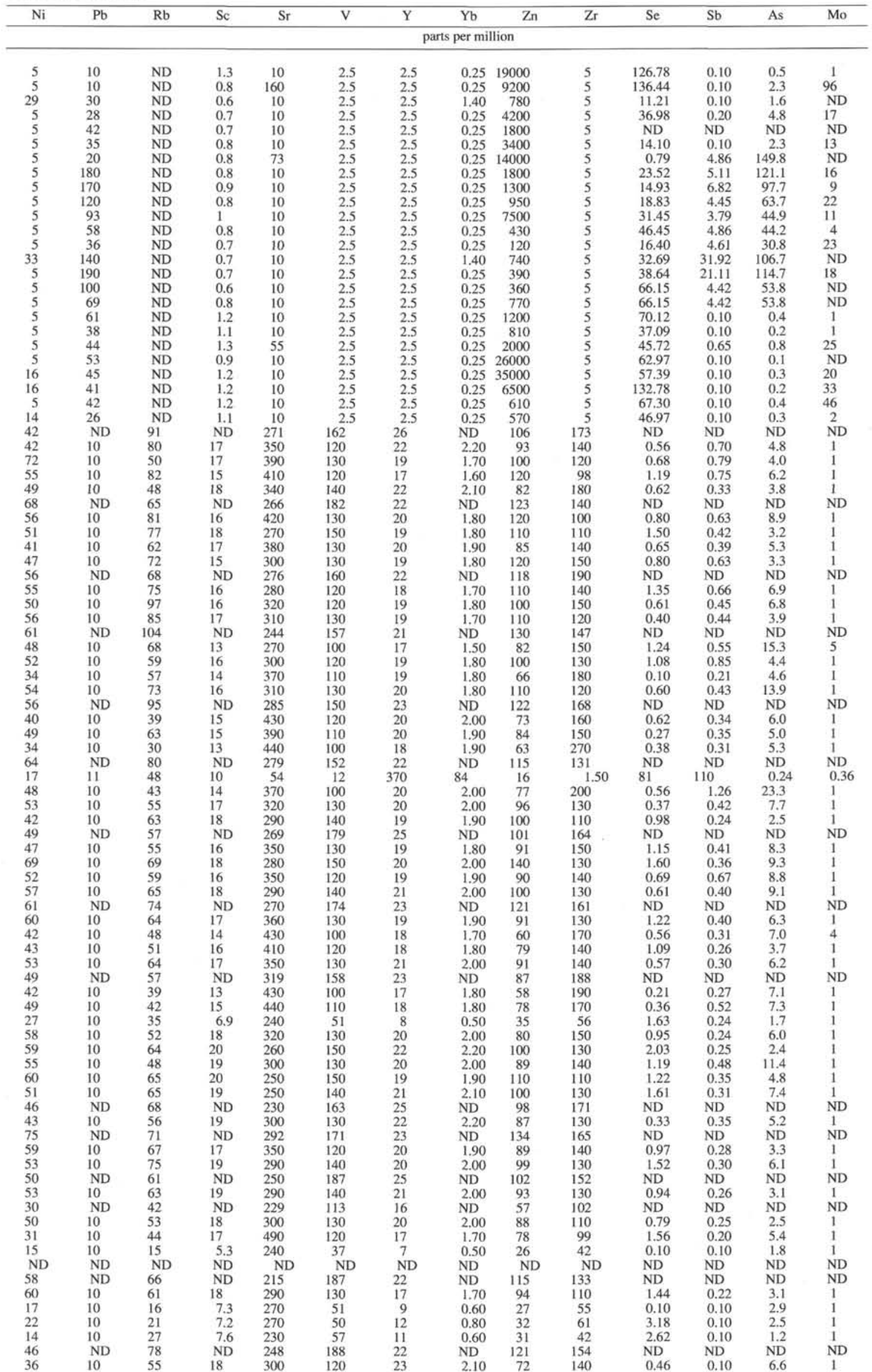


Table 1 (continued).

\begin{tabular}{|c|c|c|c|c|c|c|}
\hline & & & & Udepth & Ldepth & Depth \\
\hline Leg & Hole & Core & Section & $(\mathrm{cm})$ & $(\mathrm{cm})$ & (mbsf) \\
\hline 139 & $857 \mathrm{C}$ & $10 \mathrm{R}$ & 1. & 65 & 67 & 124.75 \\
\hline 139 & $857 \mathrm{C}$ & $11 \mathrm{R}$ & i & 124 & 126 & 135.04 \\
\hline 139 & $857 \mathrm{C}$ & $12 \mathrm{R}$ & i & 9 & 10 & 143.59 \\
\hline 139 & $857 \mathrm{C}$ & $12 R$ & i & 40 & 43 & 143.90 \\
\hline 139 & $857 \mathrm{C}$ & $12 R$ & i & 47 & 48 & 143.97 \\
\hline 139 & $857 \mathrm{C}$ & $12 R$ & i & 80 & 83 & 144.30 \\
\hline 139 & $857 \mathrm{C}$ & $12 R$ & i & 126 & 127 & 144.76 \\
\hline 139 & $857 \mathrm{C}$ & $13 R$ & i & 6 & 8 & 153.16 \\
\hline 139 & $857 \mathrm{C}$ & $13 R$ & i & 52 & 55 & 153.62 \\
\hline 139 & $857 \mathrm{C}$ & $13 R$ & 2 & 48 & 51 & 155.08 \\
\hline 139 & $857 \mathrm{C}$ & $13 R$ & 3 & 52 & 54 & 156.62 \\
\hline 139 & $857 \mathrm{C}$ & $14 R$ & 2 & 27 & 31 & 164.57 \\
\hline 139 & $857 \mathrm{C}$ & $14 R$ & 2 & 50 & 54 & 164.80 \\
\hline 139 & $857 \mathrm{C}$ & $15 \mathrm{R}$ & $i$ & 93 & 95 & 173.43 \\
\hline 139 & $857 \mathrm{C}$ & $15 R$ & 1 & 147 & 149 & 173.97 \\
\hline 139 & $857 \mathrm{C}$ & $15 \mathrm{R}$ & 3 & 142 & 144 & 176.92 \\
\hline 139 & $857 \mathrm{C}$ & $16 \mathrm{R}$ & 1 & 15 & 17 & 182.35 \\
\hline 139 & $857 \mathrm{C}$ & $17 \mathrm{R}$ & i & 82 & 86 & 192.72 \\
\hline 139 & $857 \mathrm{C}$ & $17 \mathrm{R}$ & 2 & 61 & 65 & 194.01 \\
\hline 139 & $857 \mathrm{C}$ & $18 \mathrm{R}$ & 1 & 76 & 80 & 202.36 \\
\hline 139 & $857 \mathrm{C}$ & $18 \mathrm{R}$ & 2 & 30 & 34 & 203.40 \\
\hline 139 & $857 \mathrm{C}$ & $19 R$ & 2 & 57 & 61 & 213.37 \\
\hline 139 & $857 \mathrm{C}$ & $19 \mathrm{R}$ & 2 & 78 & 82 & 213.58 \\
\hline 139 & $857 \mathrm{C}$ & $2 \mathrm{IR}$ & $i$ & 24 & 26 & 230.84 \\
\hline 139 & $857 \mathrm{C}$ & $21 \mathrm{R}$ & 1 & 129 & 131 & 231.89 \\
\hline 139 & $857 \mathrm{C}$ & $2 \mathrm{IR}$ & 3 & 27 & 29 & 233.87 \\
\hline 139 & $857 \mathrm{C}$ & $22 \mathrm{R}$ & 1 & 28 & 32 & 240.58 \\
\hline 139 & $857 \mathrm{C}$ & $22 \mathrm{R}$ & $i$ & 124 & 127 & 241.54 \\
\hline 139 & $857 \mathrm{C}$ & $22 \mathrm{R}$ & CC & 1 & 5 & 242.01 \\
\hline 139 & $857 \mathrm{C}$ & $24 \mathrm{R}$ & 1 & 31 & 35 & 259.51 \\
\hline 139 & $857 \mathrm{C}$ & $24 R$ & i & 57 & 59 & 259.77 \\
\hline 139 & $857 \mathrm{C}$ & $24 R$ & 2 & 5 & 7 & 260.75 \\
\hline 139 & $857 \mathrm{C}$ & $24 \mathrm{R}$ & 2 & 33 & 37 & 261.03 \\
\hline 139 & $857 \mathrm{C}$ & $25 \mathrm{R}$ & 1 & 6 & 8 & 268.86 \\
\hline 139 & $857 \mathrm{C}$ & $25 R$ & i & 51 & 54 & 269.31 \\
\hline 139 & $857 \mathrm{C}$ & $26 \mathrm{R}$ & 1 & 18 & 20 & 274.68 \\
\hline $\begin{array}{l}139 \\
\end{array}$ & $857 \mathrm{C}$ & $26 \mathrm{R}$ & i & 66 & 68 & 275.16 \\
\hline 139 & $857 \mathrm{C}$ & $26 \mathrm{R}$ & CC & 1 & $\begin{array}{r}00 \\
3\end{array}$ & 276.24 \\
\hline 139 & $857 \mathrm{C}$ & $27 \mathrm{R}$ & 1 & 116 & 120 & 285.26 \\
\hline 139 & $857 \mathrm{C}$ & $27 R$ & 2 & 87 & 90 & 286.47 \\
\hline 139 & $857 \mathrm{C}$ & $28 \mathrm{R}$ & 2 & 119 & 122 & 296.49 \\
\hline 139 & $857 \mathrm{C}$ & $28 \mathrm{R}$ & 3 & 27 & 29 & 297.07 \\
\hline 139 & $857 \mathrm{C}$ & $29 \mathrm{R}$ & 1 & 58 & 61 & 303.98 \\
\hline 139 & $857 \mathrm{C}$ & $29 R$ & ND & ND & ND & 313.00 \\
\hline 139 & $857 \mathrm{C}$ & $30 \mathrm{R}$ & 1 & 116 & 120 & 314.26 \\
\hline 139 & $857 \mathrm{C}$ & $30 \mathrm{R}$ & 2 & 74 & 77 & 315.34 \\
\hline 139 & $857 \mathrm{C}$ & $30 \mathrm{R}$ & 3 & 30 & 33 & 316.40 \\
\hline 139 & $857 \mathrm{C}$ & $31 \mathrm{R}$ & 1 & 121 & 123 & 323.91 \\
\hline 139 & $857 \mathrm{C}$ & $31 \mathrm{R}$ & 2 & 15 & 17 & 324.35 \\
\hline 139 & $857 \mathrm{C}$ & $31 \mathrm{R}$ & 2 & 102 & 105 & 325.22 \\
\hline 139 & $857 \mathrm{C}$ & $32 \mathrm{R}$ & 1 & 34 & 37 & 327.94 \\
\hline $\begin{array}{l}139 \\
\end{array}$ & $857 \mathrm{C}$ & $33 R$ & 1 & 56 & 59 & 332.96 \\
\hline 139 & $857 \mathrm{C}$ & $33 \mathrm{R}$ & 2 & 71 & 73 & 334.61 \\
\hline 139 & $857 \mathrm{C}$ & $\begin{array}{l}33 R \\
33 R\end{array}$ & 3 & 65 & 68 & $\begin{array}{l}334.01 \\
336.05\end{array}$ \\
\hline 139 & $857 \mathrm{C}$ & $34 \mathrm{R}$ & 1 & $\begin{array}{r}03 \\
120\end{array}$ & $\begin{array}{r}06 \\
122\end{array}$ & 337.70 \\
\hline 139 & $857 \mathrm{C}$ & $34 R$ & 3 & 44 & 47 & 339.94 \\
\hline 139 & $857 \mathrm{C}$ & $35 \mathrm{R}$ & 1 & 34 & 36 & 341.64 \\
\hline 139 & $857 \mathrm{C}$ & $35 R$ & 1 & 124 & 127 & 342.54 \\
\hline 139 & $857 \mathrm{C}$ & $35 \mathrm{R}$ & 5 & 31 & 33 & 344.50 \\
\hline 139 & $857 \mathrm{C}$ & $36 \mathrm{R}$ & 1 & 29 & 32 & 346.39 \\
\hline 139 & $857 \mathrm{C}$ & $36 \mathrm{R}$ & 1 & 79 & 81 & 348.89 \\
\hline 139 & $857 \mathrm{C}$ & $36 \mathrm{R}$ & 3 & 58 & 61 & 349.68 \\
\hline 139 & $857 \mathrm{C}$ & $37 \mathrm{R}$ & 1 & 115 & $\begin{array}{r}119 \\
\end{array}$ & 351.95 \\
\hline 139 & $857 \mathrm{C}$ & $37 \mathrm{R}$ & 2 & 115 & 119 & 353.45 \\
\hline 139 & $857 \mathrm{C}$ & $37 \mathrm{R}$ & 2 & 126 & 128 & 353.56 \\
\hline 139 & $857 \mathrm{C}$ & $38 \mathrm{R}$ & 2 & 50 & 53 & 357.80 \\
\hline 139 & $857 \mathrm{C}$ & $38 \mathrm{R}$ & 2 & 57 & 61 & 357.87 \\
\hline 139 & $857 \mathrm{C}$ & $39 \mathrm{R}$ & 1 & 66 & 68 & 361.06 \\
\hline 139 & $\begin{array}{l}857 \mathrm{C} \\
857\end{array}$ & $39 R$ & 2 & $\begin{array}{l}00 \\
48\end{array}$ & $\begin{array}{l}58 \\
50\end{array}$ & $\begin{array}{l}301.00 \\
362.38\end{array}$ \\
\hline $\begin{array}{l}139 \\
\end{array}$ & $857 \mathrm{C}$ & $39 \mathrm{R}$ & 3 & $\begin{array}{l}70 \\
62\end{array}$ & 65 & 364.02 \\
\hline 139 & $857 \mathrm{C}$ & $40 R$ & 2 & 30 & 35 & 367.20 \\
\hline 139 & $857 \mathrm{C}$ & $41 R$ & 2 & 89 & 91 & 377.29 \\
\hline 139 & $857 \mathrm{C}$ & $41 R$ & 2 & 122 & 126 & 377.62 \\
\hline 139 & $857 \mathrm{C}$ & $42 \mathrm{R}$ & 1 & 82 & 84 & 380.52 \\
\hline 139 & $857 \mathrm{C}$ & $42 R$ & 2 & 37 & $\begin{array}{l}04 \\
41\end{array}$ & 381.57 \\
\hline $\begin{array}{l}139 \\
\end{array}$ & $857 \mathrm{C}$ & $43 R$ & 1 & 130 & 134 & 386.00 \\
\hline 139 & $857 \mathrm{C}$ & $43 \mathrm{R}$ & 2 & 9 & 12 & 386.29 \\
\hline 139 & $857 \mathrm{C}$ & $43 R$ & 3 & 77 & 81 & 388.47 \\
\hline 139 & $857 \mathrm{C}$ & $44 R$ & 1 & 137 & 140 & 391.07 \\
\hline 139 & $857 \mathrm{C}$ & $44 R$ & CC & 12 & 16 & 392.76 \\
\hline 139 & $857 \mathrm{C}$ & $45 R$ & 1 & 134 & $\begin{array}{r}130 \\
138\end{array}$ & 395.64 \\
\hline $\begin{array}{l}139 \\
139\end{array}$ & $857 \mathrm{C}$ & $45 \mathrm{R}$ & 2 & 42 & 44 & 396.22 \\
\hline $\begin{array}{l}139 \\
\end{array}$ & $857 \mathrm{C}$ & $45 \mathrm{R}$ & 2 & $\begin{array}{l}42 \\
79\end{array}$ & 81 & ND \\
\hline 139 & $857 \mathrm{C}$ & $45 \mathrm{R}$ & 2 & 81 & 83 & 396.59 \\
\hline 139 & $857 \mathrm{C}$ & $46 \mathrm{R}$ & 1 & 71 & 75 & 399.71 \\
\hline 139 & $857 \mathrm{C}$ & $47 \mathrm{R}$ & 1 & 56 & 59 & 404.56 \\
\hline 139 & $857 \mathrm{C}$ & $47 \mathrm{R}$ & 2 & 5 & 8 & 405.55 \\
\hline 139 & $857 \mathrm{C}$ & $48 \mathrm{R}$ & 1 & 68 & 70 & 409.38 \\
\hline 139 & $857 \mathrm{C}$ & $49 \mathrm{R}$ & 2 & 45 & 47 & 415.65 \\
\hline 139 & $857 \mathrm{C}$ & $49 \mathrm{R}$ & 2 & 74 & 77 & 415.94 \\
\hline
\end{tabular}


Table 1 (continued).

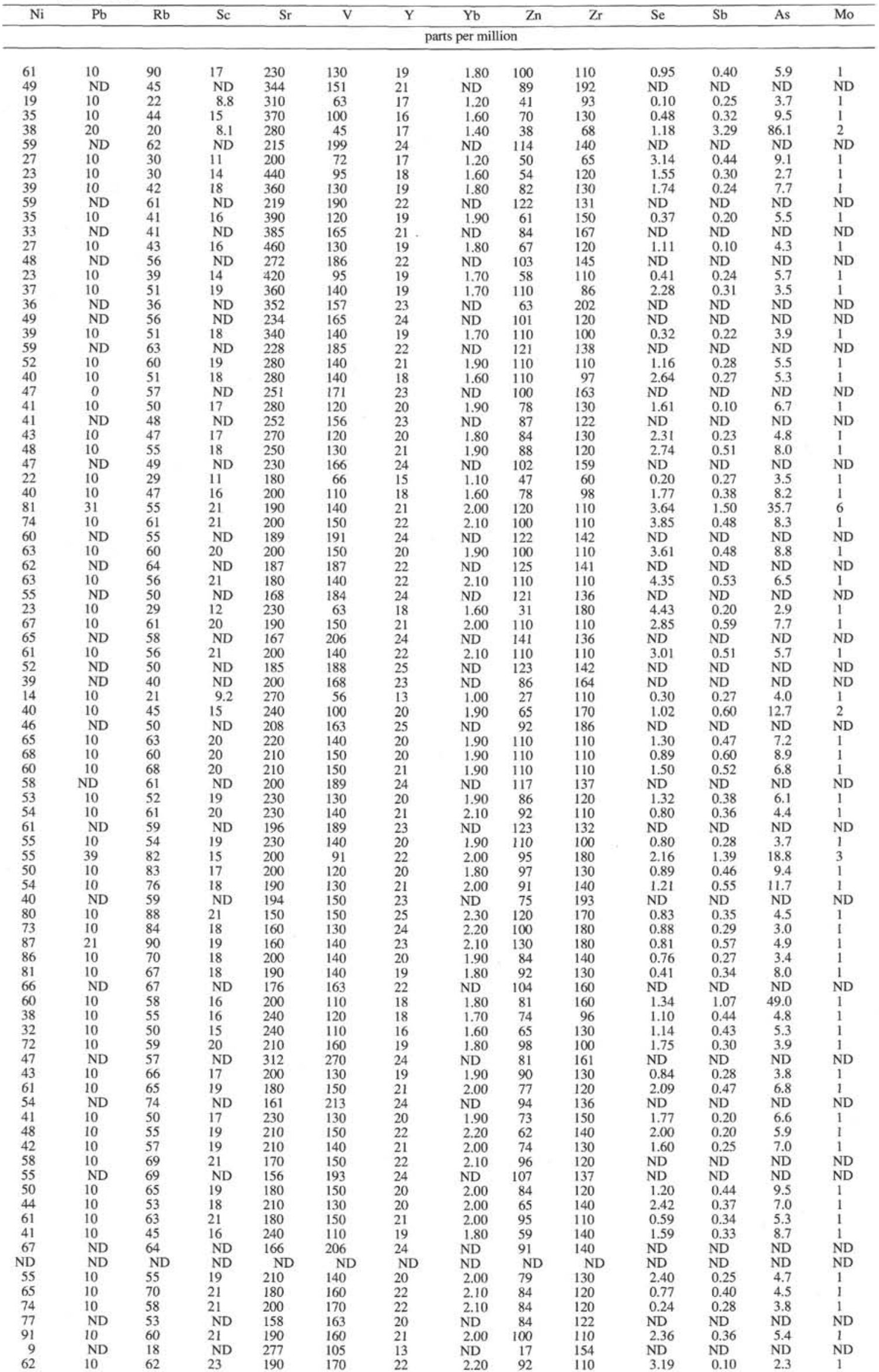


W.D. GOODFELLOW, J.M. PETER

Table 1 (continued).

\begin{tabular}{|c|c|c|c|c|c|c|}
\hline & & & & Udepth & Ldepth & Depth \\
\hline Leg & Hole & Core & Section & $(\mathrm{cm})$ & $(\mathrm{cm})$ & (mbsf) \\
\hline 139 & $857 \mathrm{C}$ & $50 \mathrm{R}$ & 2 & 42 & 44 & 420.22 \\
\hline 139 & $857 \mathrm{C}$ & $51 R$ & 1 & 28 & 30 & 423.68 \\
\hline 139 & $857 \mathrm{C}$ & SIR & 2 & 12 & 15 & 425.02 \\
\hline 139 & $857 \mathrm{C}$ & $53 \mathrm{R}$ & 1 & 24 & 26 & 433.04 \\
\hline 139 & $857 \mathrm{C}$ & $53 R$ & 1 & 50 & 52 & 433.30 \\
\hline 139 & $857 \mathrm{C}$ & $55 \mathrm{R}$ & 1 & 17 & 20 & 442.17 \\
\hline 139 & $857 \mathrm{C}$ & $55 \mathrm{R}$ & 1 & 24 & 26 & 442.24 \\
\hline 139 & $857 \mathrm{C}$ & $55 \mathrm{R}$ & 1 & 25 & 27 & 442.25 \\
\hline 139 & $857 \mathrm{C}$ & $58 \mathrm{R}$ & 1 & 16 & 17 & 461.66 \\
\hline 139 & $857 \mathrm{C}$ & $61 R$ & $i$ & 96 & 97 & 491.46 \\
\hline 139 & $857 \mathrm{C}$ & 6IR & 1 & 113 & 115 & 491.63 \\
\hline 139 & $857 \mathrm{C}$ & $61 R$ & 1 & 129 & 131 & 491.79 \\
\hline 139 & $857 \mathrm{C}$ & $63 R$ & $i$ & 13 & 16 & 509.83 \\
\hline 139 & $857 \mathrm{C}$ & $65 R$ & 1 & 15 & 17 & 529.25 \\
\hline 139 & $857 \mathrm{C}$ & $66 \mathrm{R}$ & 1 & 15 & 17 & 538.95 \\
\hline 139 & $857 \mathrm{C}$ & $66 \mathrm{R}$ & 1 & 21 & 23 & 539.01 \\
\hline 139 & $857 \mathrm{C}$ & $66 \mathrm{R}$ & 1 & 89 & 91 & 539.69 \\
\hline 139 & $857 \mathrm{C}$ & $67 \mathrm{R}$ & 1 & 7 & 9 & 548.47 \\
\hline 139 & $857 \mathrm{C}$ & $67 R$ & 1 & 55 & 57 & 548.95 \\
\hline 139 & 857D & OIR & 1 & 128 & 130 & 582.78 \\
\hline 139 & 857D & OIR & 1 & 137 & 139 & 582.87 \\
\hline 139 & 857D & $01 R$ & 2 & 36 & 38 & 583.36 \\
\hline 139 & 857D & 04R & 2 & 75 & 77 & 611.15 \\
\hline 139 & $857 \mathrm{D}$ & 05R & 1 & 26 & 28 & 618.86 \\
\hline 139 & 857D & 06R & 1 & 20 & 22 & 628.10 \\
\hline 139 & 857D & IIR & 1 & 1 & 3 & 676.21 \\
\hline 139 & $857 \mathrm{D}$ & $14 \mathrm{R}$ & 1 & 22 & 25 & 705.00 \\
\hline 139 & 857D & 15R & 1 & 74 & 76 & 715.54 \\
\hline 139 & 857D & 16R & 1 & 53 & 55 & 725.03 \\
\hline 139 & 857D & $17 R$ & 1 & 34 & 36 & 734.24 \\
\hline 139 & $857 \mathrm{D}$ & $17 \mathrm{R}$ & 1 & 146 & 148 & 735.36 \\
\hline 139 & 857D & $17 \mathrm{R}$ & 2 & 10 & 13 & 735.50 \\
\hline 139 & 857D & $17 R$ & 2 & 53 & 55 & 735.93 \\
\hline 139 & 857D & $17 \mathrm{R}$ & 3 & 23 & 25 & 737.07 \\
\hline 139 & 857D & $21 R$ & 1 & 140 & 143 & 773.60 \\
\hline 139 & 857D & $21 \mathrm{R}$ & 2 & 14 & 16 & 773.84 \\
\hline 139 & 857D & $24 \mathrm{R}$ & 1 & 40 & 42 & 801.60 \\
\hline 139 & $857 D$ & 28R & 1 & 67 & 69 & 839.57 \\
\hline 139 & 857D & $29 \mathrm{R}$ & 1 & 11 & 12 & 848.51 \\
\hline 139 & 857D & $30 \mathrm{R}$ & $i$ & 23 & 25 & 859.13 \\
\hline 139 & $857 \mathrm{D}$ & $31 \mathrm{R}$ & 1 & 35 & 37 & 868.85 \\
\hline 139 & 857D & $34 \mathrm{R}$ & 1 & 87 & 89 & 898.37 \\
\hline 139 & 857D & $37 \mathrm{R}$ & 1 & 21 & 23 & 926.71 \\
\hline 139 & 857D & $37 \mathrm{R}$ & 1 & 38 & 40 & 926.88 \\
\hline 139 & $858 \mathrm{~A}$ & $01 \mathrm{H}$ & 1 & 76 & 78 & 0.76 \\
\hline 139 & $858 \mathrm{~A}$ & $01 \mathrm{H}$ & 1 & 81 & 83 & 0.81 \\
\hline 139 & $858 \mathrm{~A}$ & $01 \mathrm{H}$ & 2 & 5 & 7 & 1.55 \\
\hline 139 & $858 \mathrm{~A}$ & $01 \mathrm{H}$ & 2 & 32 & 34 & 1.82 \\
\hline 139 & $858 \mathrm{~A}$ & $\mathrm{O} 2 \mathrm{H}$ & 1 & 34 & 36 & 2.74 \\
\hline 139 & $858 \mathrm{~A}$ & $02 \mathrm{H}$ & i & 125 & 127 & 3.65 \\
\hline 139 & $858 \mathrm{~A}$ & $02 \mathrm{H}$ & 3 & 27 & 31 & 5.67 \\
\hline 139 & $858 \mathrm{~A}$ & $02 \mathrm{H}$ & 3 & 49 & 52 & 5.89 \\
\hline 139 & $858 \mathrm{~A}$ & $02 \mathrm{H}$ & 3 & 89 & 93 & 6.29 \\
\hline 139 & $858 \mathrm{~A}$ & $02 \mathrm{H}$ & 3 & 127 & 129 & 6.67 \\
\hline 139 & $858 \mathrm{~A}$ & $02 \mathrm{H}$ & 5 & 40 & 44 & 8.80 \\
\hline 139 & $858 \mathrm{~A}$ & $02 \mathrm{H}$ & 5 & 59 & 63 & 8.99 \\
\hline 139 & $858 \mathrm{~A}$ & $02 \mathrm{H}$ & 5 & 80 & 81 & 9.20 \\
\hline 139 & $858 \mathrm{~A}$ & $02 \mathrm{H}$ & 5 & 93 & 96 & 9.33 \\
\hline 139 & $858 \mathrm{~A}$ & $02 \mathrm{H}$ & 6 & 99 & 100 & 10.89 \\
\hline 139 & $858 \mathrm{~A}$ & $02 \mathrm{H}$ & 7 & 30 & 31 & 11.70 \\
\hline 139 & $858 \mathrm{~A}$ & $02 \mathrm{H}$ & 7 & 59 & 61 & 11.97 \\
\hline 139 & $858 \mathrm{~A}$ & $02 \mathrm{H}$ & $\mathrm{CC}$ & 113 & 114 & 12.00 \\
\hline 139 & $858 \mathrm{~A}$ & $03 \mathrm{H}$ & 1 & 108 & 110 & 12.98 \\
\hline 139 & $858 \mathrm{~A}$ & $03 \mathrm{H}$ & 2 & 44 & 48 & 13.61 \\
\hline 139 & $858 \mathrm{~A}$ & $03 \mathrm{H}$ & 3 & 81 & 85 & 15.48 \\
\hline 139 & $858 \mathrm{~A}$ & $03 \mathrm{H}$ & 3 & 85 & 87 & 15.52 \\
\hline 139 & $858 \mathrm{~A}$ & $03 \mathrm{H}$ & 4 & 29 & 33 & 16.46 \\
\hline 139 & $858 \mathrm{~A}$ & $03 \mathrm{H}$ & 6 & 43 & 47 & 19.60 \\
\hline 139 & $858 \mathrm{~A}$ & $03 \mathrm{H}$ & 6 & 50 & 51 & 19.67 \\
\hline 139 & $858 \mathrm{~A}$ & $03 \mathrm{H}$ & 6 & 87 & 90 & 20.04 \\
\hline 139 & $858 \mathrm{~A}$ & $03 \mathrm{H}$ & $\mathrm{CC}$ & 1 & 3 & 21.33 \\
\hline 139 & $858 \mathrm{~A}$ & $04 \mathrm{H}$ & 2 & 66 & 70 & 23.56 \\
\hline 139 & $858 \mathrm{~A}$ & $04 \mathrm{H}$ & 2 & 76 & 80 & 23.66 \\
\hline 139 & $858 \mathrm{~A}$ & $04 \mathrm{H}$ & 2 & 79 & 83 & 23.69 \\
\hline 139 & $858 \mathrm{~A}$ & $04 \mathrm{H}$ & 2 & 96 & 100 & 23.86 \\
\hline 139 & $858 \mathrm{~A}$ & $04 \mathrm{H}$ & 4 & 46 & 50 & 26.36 \\
\hline 139 & $858 \mathrm{~A}$ & $04 \mathrm{H}$ & 4 & 103 & 107 & 26.93 \\
\hline 139 & $858 \mathrm{~A}$ & $04 \mathrm{H}$ & 5 & 102 & 106 & 28.42 \\
\hline 139 & $858 \mathrm{~A}$ & $04 \mathrm{H}$ & 6 & 48 & 50 & 29.38 \\
\hline 139 & $858 \mathrm{~A}$ & $04 \mathrm{H}$ & 6 & 65 & 69 & 29.55 \\
\hline 139 & $858 \mathrm{~A}$ & $04 \mathrm{H}$ & 6 & 87 & 89 & 29.77 \\
\hline 139 & $858 \mathrm{~A}$ & $05 \mathrm{H}$ & 3 & 98 & 102 & 34.88 \\
\hline 139 & $858 \mathrm{~A}$ & $05 \mathrm{H}$ & 1 & 57 & 61 & 31.47 \\
\hline 139 & $858 \mathrm{~A}$ & $05 \mathrm{H}$ & 2 & 2 & 4 & 32.42 \\
\hline 139 & $858 \mathrm{~A}$ & $05 \mathrm{H}$ & 2 & 134 & 137 & 33.74 \\
\hline 139 & $858 \mathrm{~A}$ & $05 \mathrm{H}$ & 3 & 100 & 105 & 34.90 \\
\hline 139 & $858 \mathrm{~A}$ & $05 \mathrm{H}$ & 3 & 71 & 75 & 34.61 \\
\hline 139 & $858 \mathrm{~A}$ & $05 \mathrm{H}$ & 4 & 27 & 30 & 35.67 \\
\hline 139 & $858 \mathrm{~A}$ & $05 \mathrm{H}$ & 5 & 54 & 57 & 37.44 \\
\hline 139 & $858 \mathrm{~A}$ & $05 \mathrm{H}$ & 6 & 40 & 45 & 38.80 \\
\hline
\end{tabular}


Table 1 (continued).

\begin{tabular}{|c|c|c|c|c|c|c|}
\hline $\mathrm{Ni}$ & $\mathrm{Pb}$ & $\mathrm{Rb}$ & $\mathrm{Sc}$ & $\mathrm{Sr}$ & V & $\mathrm{Y}$ \\
\hline & & & & & & \\
\hline 56 & 10 & 57 & 21 & 240 & 160 & 21 \\
\hline 57 & ND & 52 & ND & 201 & 197 & 25 \\
\hline 31 & 10 & 24 & 16 & 320 & 120 & 18 \\
\hline 63 & ND & 48 & ND & 229 & 206 & 25 \\
\hline 57 & 10 & 44 & 21 & 280 & 150 & 22 \\
\hline 51 & 10 & 24 & 19 & 330 & 140 & 21 \\
\hline 39 & 21 & 22 & 17 & 360 & 120 & 20 \\
\hline 34 & ND & 13 & ND & 296 & 130 & 24 \\
\hline 53 & 10 & 23 & 22 & 300 & 160 & 21 \\
\hline 88 & 10 & 15 & 47 & 290 & 260 & 32 \\
\hline 21 & ND & 4 & ND & 359 & 107 & 18 \\
\hline 21 & 10 & 10 & 14 & 150 & 100 & 12 \\
\hline 38 & ND & 1 & ND & 408 & 177 & 23 \\
\hline 38 & ND & $i$ & ND & 341 & 144 & 23 \\
\hline 42 & ND & 1 & ND & 341 & 173 & 22 \\
\hline 84 & 10 & 10 & 32 & 290 & 210 & 34 \\
\hline 130 & 10 & 10 & 36 & 150 & 280 & 34 \\
\hline 21 & 10 & 10 & 12 & 330 & 88 & 15 \\
\hline 16 & ND & 1 & ND & 154 & 105 & 14 \\
\hline 21 & ND & 0 & ND & 57 & 93 & 14 \\
\hline 24 & 10 & 10 & 10 & 72 & 82 & 14 \\
\hline 30 & 10 & 10 & 12 & 120 & 99 & 14 \\
\hline 49 & 10 & 10 & 19 & 250 & 140 & 19 \\
\hline 31 & 10 & 10 & 15 & 350 & 130 & 16 \\
\hline 21 & 10 & 10 & 12 & 110 & 90 & 14 \\
\hline 18 & 10 & 10 & 10 & 270 & 74 & 14 \\
\hline 36 & 10 & 10 & 18 & 370 & 140 & 21 \\
\hline 40 & 10 & 10 & 17 & 310 & 140 & 21 \\
\hline 37 & 10 & 10 & 18 & 320 & 130 & 20 \\
\hline 28 & 10 & 10 & 12 & 380 & 89 & 15 \\
\hline 46 & 10 & 10 & 19 & 340 & 150 & 21 \\
\hline 45 & 10 & 10 & 18 & 350 & 130 & 21 \\
\hline 26 & 10 & 10 & 10 & 290 & 74 & 14 \\
\hline 14 & 10 & 10 & 8.6 & 310 & 56 & 12 \\
\hline 33 & 10 & 10 & 17 & 300 & 120 & 21 \\
\hline 26 & 10 & 10 & 14 & 300 & 100 & 17 \\
\hline 23 & 10 & 10 & 14 & 330 & 110 & 16 \\
\hline 21 & 10 & 10 & 15 & 340 & 110 & 17 \\
\hline 27 & 10 & 10 & 16 & 220 & 110 & 16 \\
\hline 35 & 10 & 10 & 20 & 380 & 140 & 20 \\
\hline 27 & 10 & 10 & 15 & 180 & 98 & 18 \\
\hline 23 & 20 & 10 & 15 & 410 & 94 & 18 \\
\hline 20 & ND & 1 & ND & 359 & 143 & 18 \\
\hline 14 & 10 & 10 & 13 & 420 & 99 & 15 \\
\hline 36 & 23 & 96 & 15 & 420 & 110 & 21 \\
\hline ND & ND & ND & ND & ND & ND & ND \\
\hline 27 & 23 & 120 & 16 & 240 & 110 & 27 \\
\hline 42 & 20 & 70 & 18 & 290 & 130 & 21 \\
\hline ND & ND & ND & ND & ND & ND & ND \\
\hline 42 & 20 & 73 & 17 & 380 & 130 & 19 \\
\hline 45 & 20 & 72 & 15 & 460 & 120 & 19 \\
\hline 43 & 20 & 100 & 14 & 440 & 100 & 18 \\
\hline 50 & 20 & 80 & 14 & 400 & 110 & 17 \\
\hline 46 & 20 & 99 & 17 & 310 & 120 & 20 \\
\hline 60 & 20 & 69 & 18 & 330 & 140 & 20 \\
\hline 55 & 20 & 75 & 17 & 350 & 130 & 20 \\
\hline 42 & 20 & 93 & 16 & 310 & 140 & 19 \\
\hline 53 & 20 & 78 & 19 & 310 & 140 & 20 \\
\hline 10 & 20 & 25 & 7.6 & 510 & 56 & 14 \\
\hline 10 & 20 & 26 & 4.5 & 280 & 32 & 7 \\
\hline 51 & 20 & 77 & 18 & 290 & 130 & 20 \\
\hline 11 & 20 & 23 & 7.2 & 400 & 57 & 17 \\
\hline 26 & 20 & 26 & 13 & 450 & 98 & 15 \\
\hline 42 & 20 & 85 & 15 & 340 & 110 & 19 \\
\hline 48 & ND & 98 & ND & 303 & 160 & 23 \\
\hline 40 & 20 & 100 & 15 & 300 & 120 & 19 \\
\hline 43 & 20 & 92 & 15 & 340 & 130 & 19 \\
\hline 42 & 20 & 82 & 15 & 310 & 120 & 19 \\
\hline 40 & 20 & ND & 11 & 250 & 74 & 22 \\
\hline 43 & 20 & 83 & 16 & 290 & 120 & 17 \\
\hline 45 & 20 & 86 & 14 & 280 & 100 & 22 \\
\hline 54 & 20 & 130 & is & 230 & 110 & 18 \\
\hline 62 & 22 & 140 & 15 & 190 & 120 & 18 \\
\hline 67 & ND & 133 & ND & 212 & 146 & 22 \\
\hline 44 & 20 & 77 & 12 & 270 & 87 & 20 \\
\hline 47 & 20 & 110 & 17 & 210 & 120 & 19 \\
\hline 49 & 20 & 120 & 16 & 170 & 130 & 17 \\
\hline 51 & 20 & 110 & 15 & 210 & 110 & 18 \\
\hline 58 & 20 & 120 & 15 & 190 & 120 & 20 \\
\hline 51 & 20 & 130 & 17 & 190 & 130 & 17 \\
\hline 46 & 20 & 120 & 15 & 180 & 120 & 22 \\
\hline 66 & 20 & 130 & 17 & 150 & 130 & 21 \\
\hline 50 & 21 & 120 & 15 & 200 & 120 & 18 \\
\hline 10 & 20 & 48 & 6.2 & 170 & 42 & 35 \\
\hline 35 & 20 & 73 & 12 & 300 & 86 & 24 \\
\hline ND & ND & ND & ND & ND & ND & ND \\
\hline 53 & 20 & 110 & 17 & 160 & 130 & 17 \\
\hline 40 & 20 & 77 & 13 & 240 & 90 & 32 \\
\hline 48 & 20 & 99 & 14 & 200 & 110 & 18 \\
\hline 31 & 20 & 73 & 10 & 180 & 66 & 18 \\
\hline
\end{tabular}


Table 1 (continued).

\begin{tabular}{|c|c|c|c|c|c|c|}
\hline & & & & Udepth & Ldepth & Depth \\
\hline Leg & Hole & Core & Section & $(\mathrm{cm})$ & $(\mathrm{cm})$ & (mbsf) \\
\hline 139 & $858 \mathrm{~A}$ & $05 \mathrm{H}$ & 6 & 76 & 80 & 39.16 \\
\hline 139 & $858 \mathrm{~A}$ & $05 \mathrm{H}$ & $\mathrm{CC}$ & 10 & 11 & 40.00 \\
\hline 139 & $858 \mathrm{~A}$ & $06 \mathrm{H}$ & 1 & 74 & 76 & 41.14 \\
\hline 139 & $858 \mathrm{~A}$ & $06 \mathrm{H}$ & 1 & 114 & 117 & 41.54 \\
\hline 139 & $858 \mathrm{~A}$ & $06 \mathrm{H}$ & 2 & 94 & 96 & 42.84 \\
\hline 139 & $858 \mathrm{~A}$ & $06 \mathrm{H}$ & 3 & 77 & 79 & 44.17 \\
\hline 139 & $858 \mathrm{~A}$ & $06 \mathrm{H}$ & 3 & 88 & 91 & 44.28 \\
\hline 139 & $858 \mathrm{~A}$ & $07 \mathrm{H}$ & 1 & 77 & 80 & 50.67 \\
\hline 139 & $858 \mathrm{~A}$ & $07 \mathrm{H}$ & 2 & 63 & 66 & 52.03 \\
\hline 139 & $858 \mathrm{~A}$ & $07 \mathrm{H}$ & 4 & 83 & 86 & 55.23 \\
\hline 139 & $858 \mathrm{~A}$ & $07 \mathrm{H}$ & 4 & 88 & 91 & 55.28 \\
\hline 139 & $858 \mathrm{~A}$ & $07 \mathrm{H}$ & 4 & 93 & 97 & 55.33 \\
\hline 139 & $858 \mathrm{~A}$ & $07 \mathrm{H}$ & 5 & 54 & 57 & 56.44 \\
\hline 139 & $858 \mathrm{~A}$ & $07 \mathrm{H}$ & 6 & 67 & 71 & 58.07 \\
\hline 139 & $858 \mathrm{~A}$ & $08 \mathrm{H}$ & 1 & 28 & 30 & 59.18 \\
\hline 139 & $858 \mathrm{~A}$ & $08 \mathrm{H}$ & 2 & 31 & 33 & 60.64 \\
\hline 139 & $858 \mathrm{~A}$ & $08 \mathrm{H}$ & 2 & 39 & 41 & 60.72 \\
\hline 139 & $858 \mathrm{~A}$ & $08 \mathrm{H}$ & 2 & 89 & 91 & 61.22 \\
\hline 139 & $858 \mathrm{~A}$ & $09 \mathrm{X}$ & 1 & 92 & 95 & 63.42 \\
\hline 139 & $858 \mathrm{~A}$ & $09 \mathrm{X}$ & 2 & 38 & 40 & 64.38 \\
\hline 139 & $858 \mathrm{~A}$ & $09 \mathrm{X}$ & 2 & 114 & 116 & 65.14 \\
\hline 139 & $858 \mathrm{~A}$ & $09 \mathrm{X}$ & 3 & 108 & 112 & 66.58 \\
\hline 139 & $858 \mathrm{~A}$ & $09 \mathrm{X}$ & 4 & 47 & 51 & 67.47 \\
\hline 139 & $858 \mathrm{~A}$ & $09 \mathrm{X}$ & 4 & 52 & 56 & 67.52 \\
\hline 139 & $858 \mathrm{~A}$ & $09 \mathrm{X}$ & 5 & 36 & 40 & 68.86 \\
\hline 139 & $858 \mathrm{~A}$ & $09 \mathrm{X}$ & 6 & 110 & 114 & 71.10 \\
\hline 139 & $858 \mathrm{~A}$ & $09 \mathrm{X}$ & 6 & 129 & 133 & 71.29 \\
\hline 139 & $858 \mathrm{~A}$ & $11 \mathrm{X}$ & 1 & 2 & 7 & 72.92 \\
\hline 139 & $858 \mathrm{~A}$ & $11 X$ & $\mathrm{CC}$ & 10 & 12 & 73.57 \\
\hline 139 & $858 \mathrm{~A}$ & IIX & $\mathrm{CC}$ & 17 & 21 & 73.64 \\
\hline 139 & $858 \mathrm{~A}$ & $12 x$ & 1 & 18 & 20 & 81.78 \\
\hline 139 & $858 \mathrm{~A}$ & $12 \mathrm{X}$ & $\mathrm{CC}$ & 11 & 13 & 81.91 \\
\hline 139 & $858 \mathrm{~A}$ & $14 \mathrm{X}$ & $\mathrm{CC}$ & 11 & 13 & 101.11 \\
\hline 139 & $858 \mathrm{~A}$ & $15 \mathrm{X}$ & 1 & 35 & 37 & 110.95 \\
\hline 139 & $858 \mathrm{~A}$ & $15 \mathrm{X}$ & 1 & 60 & 62 & 111.20 \\
\hline 139 & $858 \mathrm{~A}$ & $16 \mathrm{X}$ & 1 & 3 & 5 & 120.33 \\
\hline 139 & $858 \mathrm{~A}$ & $16 \mathrm{X}$ & 1 & 38 & 40 & 120.68 \\
\hline 139 & $858 \mathrm{~A}$ & $18 \mathrm{X}$ & 1 & 116 & 118 & 140.76 \\
\hline 139 & $858 \mathrm{~A}$ & $18 \mathrm{X}$ & 2 & 109 & 111 & 142.19 \\
\hline 139 & $858 \mathrm{~A}$ & $18 \mathrm{X}$ & 3 & 14 & 16 & 142.74 \\
\hline 139 & $858 \mathrm{~A}$ & $18 \mathrm{X}$ & 3 & 16 & 20 & 142.76 \\
\hline 139 & $858 \mathrm{~A}$ & $19 \mathrm{X}$ & 1 & 28 & 30 & 149.58 \\
\hline 139 & $858 \mathrm{~A}$ & $20 \mathrm{X}$ & 1 & 62 & 64 & 159.62 \\
\hline 139 & $858 \mathrm{~A}$ & $20 \mathrm{X}$ & $i$ & 128 & 130 & 160.28 \\
\hline 139 & $858 \mathrm{~A}$ & $20 \mathrm{X}$ & 3 & 39 & 41 & 162.32 \\
\hline 139 & $858 \mathrm{~A}$ & $20 \mathrm{X}$ & 4 & 100 & 103 & 164.44 \\
\hline 139 & $858 \mathrm{~A}$ & $21 \mathrm{X}$ & 1 & 117 & 120 & 169.77 \\
\hline 139 & $858 \mathrm{~A}$ & $21 X$ & 2 & 31 & 34 & 170.41 \\
\hline 139 & $858 \mathrm{~A}$ & $21 X$ & 3 & 57 & 59 & 171.98 \\
\hline 139 & $858 \mathrm{~A}$ & $23 \mathrm{X}$ & 1 & 73 & 75 & 188.63 \\
\hline 139 & $858 \mathrm{~A}$ & $23 \mathrm{X}$ & 1 & 113 & 115 & 189.03 \\
\hline 139 & $858 \mathrm{~A}$ & $24 X$ & 1 & 33 & 35 & 197.93 \\
\hline 139 & $858 \mathrm{~A}$ & $24 \mathrm{X}$ & 1 & 72 & 74 & 198.32 \\
\hline 139 & $858 \mathrm{~A}$ & $25 \mathrm{X}$ & 1 & 29 & 32 & 207.59 \\
\hline 139 & $858 \mathrm{~A}$ & $26 \mathrm{X}$ & $\mathrm{CC}$ & 4 & 6 & 216.94 \\
\hline 139 & $858 \mathrm{~A}$ & $27 \mathrm{X}$ & 1 & 33 & 35 & 226.93 \\
\hline 139 & $858 \mathrm{~A}$ & $28 \mathrm{X}$ & $\mathrm{CC}$ & 4 & 5 & 236.24 \\
\hline 139 & $858 \mathrm{~A}$ & $29 \mathrm{X}$ & 1 & 30 & 32 & 246.20 \\
\hline 139 & $858 \mathrm{~A}$ & $30 \mathrm{X}$ & 1 & 4 & 8 & 255.64 \\
\hline 139 & $858 \mathrm{~A}$ & $30 \mathrm{X}$ & 1 & 67 & 70 & 256.27 \\
\hline 139 & $858 \mathrm{~A}$ & $31 X$ & $i$ & 65 & 67 & 265.95 \\
\hline 139 & $858 \mathrm{~A}$ & $35 X$ & 0 & 5 & 6 & 301.45 \\
\hline 139 & $858 \mathrm{~B}$ & $01 \mathrm{H}$ & 2 & 21 & 23 & 1.71 \\
\hline 139 & $858 \mathrm{~B}$ & $01 \mathrm{H}$ & 2 & 42 & 46 & 1.92 \\
\hline 139 & $858 \mathrm{~B}$ & $01 \mathrm{H}$ & 2 & 50 & 54 & 2.00 \\
\hline 139 & $858 \mathrm{~B}$ & $01 \mathrm{H}$ & 3 & 23 & 27 & 3.23 \\
\hline 139 & $858 \mathrm{~B}$ & $01 \mathrm{H}$ & 4 & 67 & 71 & 5.17 \\
\hline 139 & $858 \mathrm{~B}$ & $01 \mathrm{H}$ & 5 & 14 & 18 & 6.14 \\
\hline 139 & $858 \mathrm{~B}$ & $01 \mathrm{H}$ & 5 & 21 & 25 & 6.21 \\
\hline 139 & $858 \mathrm{~B}$ & $01 \mathrm{H}$ & $\mathrm{CC}$ & 8 & 12 & 6.98 \\
\hline 139 & $858 \mathrm{~B}$ & $02 \mathrm{H}$ & 1 & 73 & 76 & 7.93 \\
\hline 139 & $858 \mathrm{~B}$ & $02 \mathrm{H}$ & 2 & 89 & 91 & 9.59 \\
\hline 139 & $858 \mathrm{~B}$ & $02 \mathrm{H}$ & 2 & 121 & 124 & 9.91 \\
\hline 139 & $858 \mathrm{~B}$ & $02 \mathrm{H}$ & 2 & 125 & 127 & 9.95 \\
\hline 139 & $858 \mathrm{~B}$ & $\mathrm{O} 2 \mathrm{H}$ & 3 & 50 & 52 & 10.70 \\
\hline 139 & $858 \mathrm{~B}$ & $02 \mathrm{H}$ & 3 & 84 & 86 & 11.04 \\
\hline 139 & $858 \mathrm{~B}$ & $02 \mathrm{H}$ & 3 & 113 & 115 & 11.33 \\
\hline 139 & $858 \mathrm{~B}$ & $\mathrm{O} 2 \mathrm{H}$ & 4 & 43 & 45 & 12.13 \\
\hline 139 & $858 \mathrm{~B}$ & $02 \mathrm{H}$ & 4 & 62 & 64 & 12.32 \\
\hline 139 & $858 \mathrm{~B}$ & $02 \mathrm{H}$ & 4 & 94 & 96 & 12.64 \\
\hline 139 & $858 \mathrm{~B}$ & $02 \mathrm{H}$ & 5 & 11 & 13 & 13.31 \\
\hline 139 & $858 \mathrm{~B}$ & $02 \mathrm{H}$ & 5 & 16 & 18 & 13.36 \\
\hline 139 & $858 \mathrm{~B}$ & $02 \mathrm{H}$ & 5 & 35 & 37 & 13.55 \\
\hline 139 & $858 \mathrm{~B}$ & $02 \mathrm{H}$ & 6 & 69 & 71 & 15.39 \\
\hline 139 & $858 \mathrm{~B}$ & $02 \mathrm{H}$ & 6 & 75 & 77 & 15.45 \\
\hline 139 & $858 \mathrm{~B}$ & $05 \mathrm{H}$ & 1 & 117 & 121 & 25.07 \\
\hline 139 & $858 \mathrm{~B}$ & $05 \mathrm{H}$ & 1 & 122 & 125 & 25.12 \\
\hline 139 & $858 \mathrm{~B}$ & $05 \mathrm{H}$ & 1 & 140 & 143 & 25.30 \\
\hline 139 & $858 \mathrm{~B}$ & $05 \mathrm{H}$ & 3 & 21 & 24 & 27.11 \\
\hline 139 & $858 \mathrm{~B}$ & $05 \mathrm{H}$ & 3 & 118 & 121 & 28.08 \\
\hline
\end{tabular}


Table 1 (continued).

\begin{tabular}{|c|c|c|c|c|c|c|}
\hline $\mathrm{Ni}$ & $\mathrm{Pb}$ & $\mathrm{Rb}$ & Sc & $\mathrm{Sr}$ & V & $Y$ \\
\hline & & & & & & \\
\hline 58 & 20 & 130 & 15 & 160 & 120 & 17 \\
\hline 58 & 20 & 120 & 17 & 140 & 120 & 17 \\
\hline 59 & 20 & 120 & 18 & 130 & 130 & 18 \\
\hline ND & ND & ND & ND & ND & ND & ND \\
\hline 49 & 20 & 110 & 17 & 150 & 120 & 17 \\
\hline 59 & 20 & 120 & 15 & 140 & 120 & 16 \\
\hline 49 & 20 & 82 & 11 & 220 & 78 & 16 \\
\hline 44 & 20 & 75 & 12 & 230 & 83 & 16 \\
\hline ND & ND & ND & ND & ND & ND & ND \\
\hline 65 & 20 & 110 & 17 & 130 & 130 & 17 \\
\hline 53 & 20 & 100 & 14 & 190 & 110 & 16 \\
\hline 39 & 20 & 87 & 13 & 220 & 120 & 15 \\
\hline 50 & 20 & 96 & 14 & 160 & 110 & 19 \\
\hline 39 & 20 & 81 & 12 & 210 & 82 & 20 \\
\hline ND & ND & ND & ND & ND & ND & ND \\
\hline 58 & 20 & 120 & 15 & 150 & 120 & 19 \\
\hline 55 & 20 & 110 & 18 & 110 & 140 & 19 \\
\hline 26 & 20 & 83 & 13 & 310 & 100 & 18 \\
\hline 45 & 20 & 92 & 19 & 150 & 140 & 19 \\
\hline ND & ND & ND & ND & ND & ND & ND \\
\hline 42 & 20 & 73 & 16 & 170 & 110 & 18 \\
\hline 45 & 20 & 85 & 16 & 150 & 120 & 20 \\
\hline ND & ND & ND & ND & ND & ND & ND \\
\hline 10 & 20 & 11 & 3.3 & 320 & 21 & 17 \\
\hline 54 & 20 & 71 & 17 & 120 & 130 & 18 \\
\hline 38 & 20 & 56 & 16 & 150 & 110 & 17 \\
\hline 66 & 20 & 50 & 19 & 61 & 140 & 14 \\
\hline 36 & 20 & 30 & 13 & 210 & 100 & 13 \\
\hline 55 & 20 & 49 & 19 & 96 & 150 & 14 \\
\hline 50 & 20 & 59 & 19 & 75 & 160 & 11 \\
\hline 46 & 20 & 49 & 17 & 100 & 130 & 19 \\
\hline 47 & 48 & 33 & 17 & 130 & 120 & 17 \\
\hline 39 & 20 & 19 & 13 & 110 & 85 & 13 \\
\hline 42 & 20 & 35 & 20 & 100 & 160 & 18 \\
\hline 39 & 20 & 58 & 15 & 120 & 130 & 17 \\
\hline 64 & 20 & 37 & 20 & 99 & 160 & 14 \\
\hline 62 & 20 & 44 & 18 & 110 & 140 & 20 \\
\hline 75 & 20 & 46 & 19 & 120 & 150 & 20 \\
\hline 39 & 20 & 26 & 16 & 180 & 120 & 17 \\
\hline 37 & 24 & 32 & 15 & 200 & 110 & 19 \\
\hline 19 & 20 & 11 & 10 & 360 & 81 & 13 \\
\hline 55 & 20 & 38 & 20 & 130 & 160 & 16 \\
\hline 47 & 20 & 38 & 20 & 120 & 150 & 17 \\
\hline 59 & 20 & 47 & 20 & 110 & 150 & 18 \\
\hline 30 & 20 & 10 & 13 & 210 & 84 & 18 \\
\hline 18 & 290 & 34 & 2.4 & 140 & 50 & 5 \\
\hline 27 & ND & 22 & ND & 141 & 87 & ND \\
\hline 72 & 37 & 59 & 15 & 360 & 120 & 20 \\
\hline ND & ND & ND & ND & ND & ND & ND \\
\hline 29 & 82 & 66 & 15 & 260 & 120 & 20 \\
\hline 41 & 35 & 76 & 17 & 210 & 120 & 20 \\
\hline ND & ND & ND & ND & ND & ND & ND \\
\hline 10 & 20 & 84 & 17 & 300 & 130 & 20 \\
\hline 58 & 20 & 63 & 17 & 190 & 130 & 19 \\
\hline 45 & 20 & 81 & 18 & 260 & 130 & 19 \\
\hline
\end{tabular}


Table 1 (continued).

\begin{tabular}{|c|c|c|c|c|c|c|}
\hline & & & & Udepth & Ldepth & Depth \\
\hline Leg & Hole & Core & Section & $(\mathrm{cm})$ & $(\mathrm{cm})$ & (mbsf) \\
\hline 139 & $858 B$ & $05 \mathrm{H}$ & 3 & 124 & 128 & 28.14 \\
\hline 139 & $858 \mathrm{~B}$ & $05 \mathrm{H}$ & 4 & 27 & 29 & 28.67 \\
\hline 139 & $858 \mathrm{~B}$ & $05 \mathrm{H}$ & 4 & 33 & 37 & 28.73 \\
\hline 139 & $858 \mathrm{C}$ & OIH & 1 & 52 & 56 & 0.52 \\
\hline 139 & $858 \mathrm{C}$ & $01 \mathrm{H}$ & 2 & 38 & 42 & 1.88 \\
\hline 139 & $858 \mathrm{C}$ & $01 \mathrm{H}$ & 2 & 42 & 46 & 1.92 \\
\hline 139 & $858 \mathrm{C}$ & $01 \mathrm{H}$ & 3 & 17 & 21 & 3.17 \\
\hline 139 & $858 \mathrm{C}$ & $02 \mathrm{H}$ & 1 & 88 & 91 & 4.38 \\
\hline 139 & $858 \mathrm{C}$ & $02 \mathrm{H}$ & 2 & 15 & 17 & 5.15 \\
\hline 139 & $858 \mathrm{C}$ & $02 \mathrm{H}$ & 2 & 77 & 79 & 5.77 \\
\hline 139 & $858 \mathrm{C}$ & $02 \mathrm{H}$ & 4 & 15 & 17 & 8.15 \\
\hline 139 & $858 \mathrm{C}$ & $\mathrm{O} 2 \mathrm{H}$ & 4 & 72 & 75 & 8.72 \\
\hline 139 & $858 \mathrm{C}$ & $02 \mathrm{H}$ & 5 & 32 & 34 & 9.82 \\
\hline 139 & $858 \mathrm{C}$ & $02 \mathrm{H}$ & 6 & 78 & 81 & 11.78 \\
\hline 139 & $858 \mathrm{C}$ & $02 \mathrm{H}$ & 6 & 110 & 112 & 12.10 \\
\hline 139 & $858 \mathrm{C}$ & $02 \mathrm{H}$ & 7 & 15 & 17 & 12.65 \\
\hline 139 & $858 \mathrm{C}$ & $03 \mathrm{H}$ & 1 & 0 & 0 & 14.00 \\
\hline 139 & $858 \mathrm{C}$ & $03 \mathrm{H}$ & 1 & 24 & 26 & 13.24 \\
\hline 139 & $858 \mathrm{C}$ & $03 \mathrm{H}$ & i & 29 & 30 & 13.29 \\
\hline 139 & $858 \mathrm{C}$ & $03 \mathrm{H}$ & 1 & 49 & 51 & ND \\
\hline 139 & $858 \mathrm{C}$ & $03 \mathrm{H}$ & 1 & 78 & 81 & 13.78 \\
\hline 139 & $858 \mathrm{C}$ & $03 \mathrm{H}$ & 1 & 108 & 110 & 14.08 \\
\hline 139 & $858 \mathrm{C}$ & $03 \mathrm{H}$ & 1 & 145 & 150 & 14.45 \\
\hline 139 & $858 \mathrm{C}$ & $03 \mathrm{H}$ & 2 & 10 & 15 & 14.60 \\
\hline 139 & $858 \mathrm{C}$ & $03 \mathrm{H}$ & 2 & 36 & 38 & 14.86 \\
\hline 139 & $858 \mathrm{C}$ & $03 \mathrm{H}$ & 2 & 54 & 57 & 15.04 \\
\hline 139 & $858 \mathrm{C}$ & $03 \mathrm{H}$ & 2 & 110 & 115 & 15.60 \\
\hline 139 & $858 \mathrm{C}$ & $03 \mathrm{H}$ & 2 & 124 & 126 & 15.74 \\
\hline 139 & $858 \mathrm{C}$ & $03 \mathrm{H}$ & 2 & 133 & 135 & 15.83 \\
\hline 139 & $858 \mathrm{C}$ & $03 \mathrm{H}$ & 2 & 136 & 139 & 15.86 \\
\hline 139 & $858 \mathrm{C}$ & $03 \mathrm{H}$ & 3 & 2 & 4 & 16.02 \\
\hline 139 & $858 \mathrm{C}$ & $03 \mathrm{H}$ & 3 & 22 & 24 & 16.22 \\
\hline 139 & $858 \mathrm{C}$ & $03 \mathrm{H}$ & 3 & 38 & 41 & 16.38 \\
\hline 139 & $858 \mathrm{C}$ & $03 \mathrm{H}$ & 3 & 68 & 70 & 16.68 \\
\hline 139 & $858 \mathrm{C}$ & $03 \mathrm{H}$ & 3 & 78 & 80 & 16.78 \\
\hline 139 & $858 \mathrm{C}$ & $03 \mathrm{H}$ & 3 & 107 & 109 & 17.07 \\
\hline 139 & $858 \mathrm{C}$ & $03 \mathrm{H}$ & 3 & 122 & 124 & 17.22 \\
\hline 139 & $858 \mathrm{C}$ & $03 \mathrm{H}$ & 4 & 77 & 80 & 18.27 \\
\hline 139 & $858 \mathrm{C}$ & $03 \mathrm{H}$ & 5 & 58 & 60 & 19.58 \\
\hline 139 & $858 \mathrm{C}$ & $03 \mathrm{H}$ & 6 & 86 & 89 & 21.36 \\
\hline 139 & $858 \mathrm{C}$ & $03 \mathrm{H}$ & 6 & 86 & 89 & 21.36 \\
\hline 139 & $858 \mathrm{C}$ & $03 \mathrm{H}$ & 7 & 6 & 9 & 22.06 \\
\hline 139 & $858 \mathrm{C}$ & $05 \mathrm{H}$ & 1 & 72 & 75 & 24.22 \\
\hline 139 & $858 \mathrm{C}$ & $05 \mathrm{H}$ & 1 & 122 & 124 & 24.72 \\
\hline 139 & $858 \mathrm{C}$ & $05 \mathrm{H}$ & 2 & 18 & 20 & 25.18 \\
\hline 139 & $858 \mathrm{C}$ & $05 \mathrm{H}$ & 2 & 106 & 108 & 26.06 \\
\hline 139 & $858 \mathrm{C}$ & $05 \mathrm{H}$ & 2 & 122 & 123 & 26.22 \\
\hline 139 & $858 \mathrm{C}$ & $05 \mathrm{H}$ & 3 & 5 & 7 & 26.55 \\
\hline 139 & $858 \mathrm{C}$ & $05 \mathrm{H}$ & 3 & 19 & 21 & 26.69 \\
\hline 139 & $858 \mathrm{C}$ & $05 \mathrm{H}$ & 3 & 61 & 63 & 27.11 \\
\hline 139 & $858 \mathrm{C}$ & $05 \mathrm{H}$ & 4 & 27 & 28 & 28.27 \\
\hline 139 & $858 \mathrm{C}$ & $05 \mathrm{H}$ & 4 & 55 & 57 & 28.55 \\
\hline 139 & $858 \mathrm{C}$ & $05 \mathrm{H}$ & 4 & 93 & 95 & 28.93 \\
\hline 139 & $858 \mathrm{C}$ & $05 \mathrm{H}$ & 5 & 21 & 23 & 29.71 \\
\hline 139 & $858 \mathrm{C}$ & $05 \mathrm{H}$ & 5 & 88 & 90 & 30.38 \\
\hline 139 & $858 \mathrm{C}$ & $05 \mathrm{H}$ & $\mathrm{CC}$ & 7 & 10 & 33.20 \\
\hline 139 & $858 \mathrm{C}$ & $06 \mathrm{H}$ & 1 & 19 & 21 & 33.19 \\
\hline 139 & $858 \mathrm{C}$ & $06 \mathrm{H}$ & 1 & 80 & 82 & 33.80 \\
\hline 139 & $858 \mathrm{C}$ & $06 \mathrm{H}$ & 1 & 123 & 125 & 34.23 \\
\hline 139 & $858 \mathrm{C}$ & $06 \mathrm{H}$ & 2 & 75 & 77 & 35.25 \\
\hline 139 & $858 \mathrm{C}$ & $06 \mathrm{H}$ & 2 & 135 & 137 & 35.85 \\
\hline 139 & $858 \mathrm{C}$ & $06 \mathrm{H}$ & 3 & 51 & 53 & 36.51 \\
\hline 139 & $858 \mathrm{C}$ & $06 \mathrm{H}$ & 3 & 104 & 106 & 37.04 \\
\hline 139 & $858 \mathrm{C}$ & $06 \mathrm{H}$ & 3 & 108 & 110 & 37.08 \\
\hline 139 & $858 \mathrm{C}$ & $06 \mathrm{H}$ & 4 & 43 & 51 & 37.93 \\
\hline 139 & $858 \mathrm{C}$ & $06 \mathrm{H}$ & 5 & 45 & 48 & 39.45 \\
\hline 139 & $858 \mathrm{C}$ & $06 \mathrm{H}$ & 5 & 76 & 79 & 39.76 \\
\hline 139 & $858 \mathrm{C}$ & $06 \mathrm{H}$ & 6 & 52 & 55 & 41.02 \\
\hline 139 & $858 \mathrm{C}$ & $07 \mathrm{H}$ & 1 & 11 & 12 & 41.61 \\
\hline 139 & $858 \mathrm{C}$ & $07 \mathrm{H}$ & 1 & 90 & 92 & 42.40 \\
\hline 139 & $858 \mathrm{C}$ & $07 \mathrm{H}$ & 2 & 53 & 55 & 43.53 \\
\hline 139 & $858 \mathrm{C}$ & $07 \mathrm{H}$ & 2 & 55 & 58 & 43.55 \\
\hline 139 & $858 \mathrm{C}$ & $07 \mathrm{H}$ & 2 & 60 & 64 & 43.60 \\
\hline 139 & $858 \mathrm{C}$ & $07 \mathrm{H}$ & 2 & 143 & 146 & 44.43 \\
\hline 139 & $858 \mathrm{C}$ & $10 \mathrm{X}$ & $\mathrm{CC}$ & 2 & 4 & 49.52 \\
\hline 139 & $858 \mathrm{C}$ & $10 \mathrm{X}$ & $\mathrm{CC}$ & 37 & 39 & 49.87 \\
\hline 139 & $858 \mathrm{C}$ & $11 X$ & 1 & 33 & 35 & 54.83 \\
\hline 139 & $858 \mathrm{C}$ & $11 X$ & 1 & 48 & 51 & 54.98 \\
\hline 139 & $858 \mathrm{C}$ & $12 \mathrm{X}$ & 1 & 42 & 45 & 64.20 \\
\hline 139 & $858 \mathrm{C}$ & $12 \mathrm{X}$ & 2 & 80 & 82 & 66.30 \\
\hline 139 & $858 \mathrm{C}$ & $12 \mathrm{X}$ & 3 & 87 & 90 & 67.87 \\
\hline 139 & $858 \mathrm{C}$ & $12 \mathrm{X}$ & $\mathrm{CC}$ & 8 & 10 & 68.14 \\
\hline 139 & $858 \mathrm{C}$ & $13 \mathrm{X}$ & 1 & 1 & 16 & 73.71 \\
\hline 139 & $858 \mathrm{C}$ & $13 \mathrm{X}$ & 1 & 25 & 28 & 73.95 \\
\hline 139 & $858 \mathrm{C}$ & $14 \mathrm{X}$ & 1 & 34 & 36 & 83.74 \\
\hline 139 & $858 \mathrm{C}$ & $14 X$ & 1 & 49 & 51 & ND \\
\hline 139 & 858D & $01 \mathrm{H}$ & 1 & 105 & 107 & 1.05 \\
\hline 139 & $858 \mathrm{D}$ & $01 \mathrm{H}$ & 1 & 115 & 119 & 1.15 \\
\hline 139 & $858 \mathrm{D}$ & $01 \mathrm{H}$ & 3 & 27 & 31 & 3.27 \\
\hline 139 & 858D & $01 \mathrm{H}$ & 3 & 98 & 102 & 3.98 \\
\hline
\end{tabular}


Table 1 (continued).

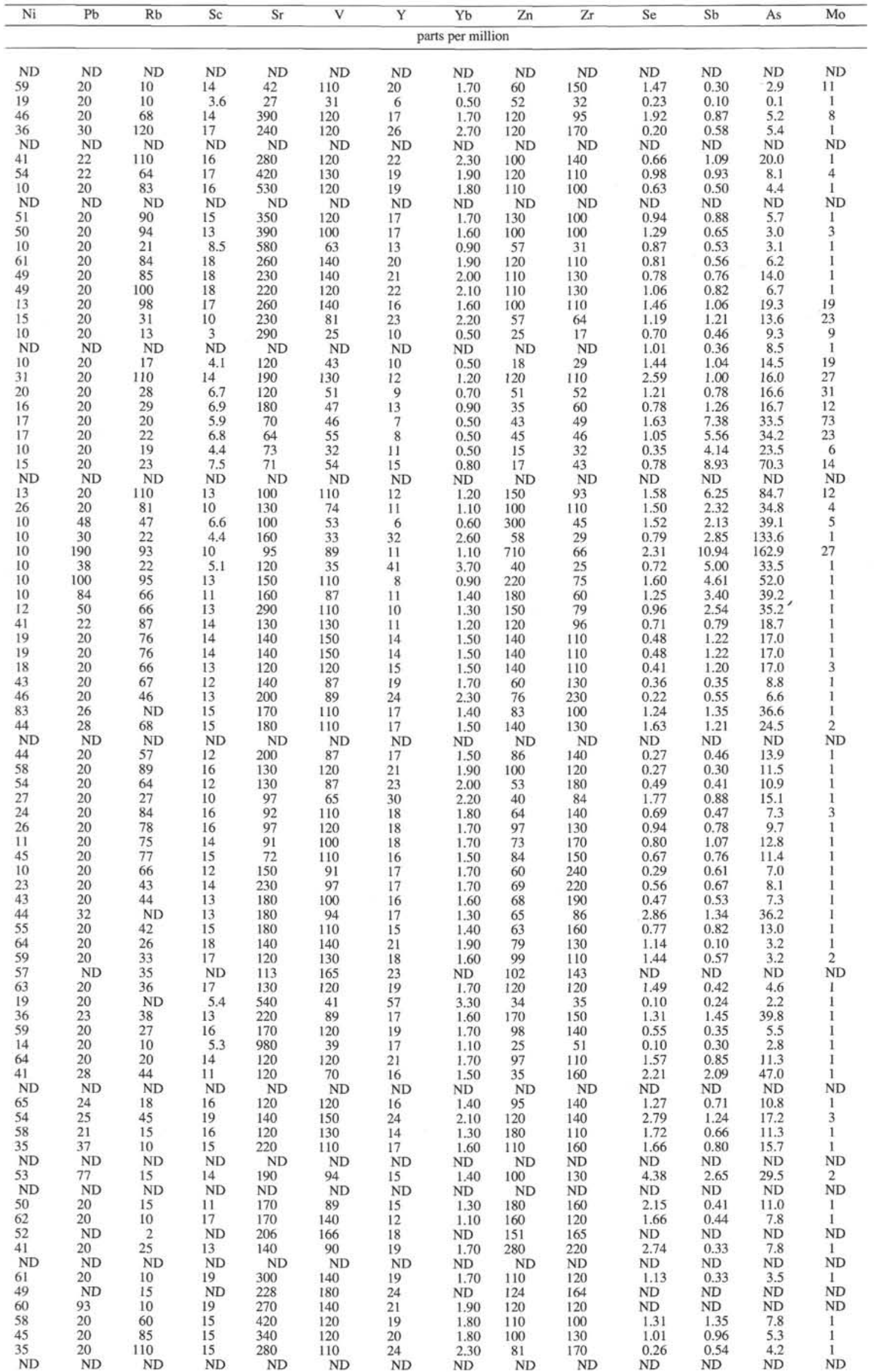


W.D. GOODFELLOW, J.M. PETER

Table 1 (continued).

\begin{tabular}{|c|c|c|c|c|c|c|c|c|c|c|c|c|c|c|c|}
\hline & & & & Udepth & Ldepth & Depth & & & $\mathrm{Be}$ & $\mathrm{Ce}$ & Co & $\mathrm{Cr}$ & $\mathrm{Cu}$ & $\mathrm{La}$ & $\mathrm{Nb}$ \\
\hline Leg & Hole & Core & Section & $(\mathrm{cm})$ & $(\mathrm{cm})$ & (mbsf) & $\mathrm{Ba}$ & $\mathrm{Ag}$ & & \multicolumn{6}{|c|}{ parts per million } \\
\hline 139 & $858 \mathrm{D}$ & $01 \mathrm{H}$ & 3 & 112 & 115 & 4.12 & 660 & 1 & 1.6 & ND & 21 & 76 & 56 & 21 & 10 \\
\hline 139 & $858 \mathrm{D}$ & $01 \mathrm{H}$ & 4 & 80 & 83 & 5.30 & 610 & 1 & 1.3 & ND & 23 & 77 & 68 & 18 & 10 \\
\hline 139 & $858 \mathrm{D}$ & $01 \mathrm{H}$ & 5 & 84 & 88 & 6.84 & 680 & 1 & 1.2 & ND & 22 & 100 & 58 & 16 & 10 \\
\hline 139 & 858D & $01 \mathrm{H}$ & 5 & 106 & 110 & 7.06 & 670 & 1 & 1.2 & ND & 23 & 99 & 57 & 16 & 12 \\
\hline 139 & $858 \mathrm{D}$ & $01 \mathrm{H}$ & 6 & 25 & 28 & 7.75 & 590 & $i$ & 1.4 & ND & 21 & 75 & 54 & 18 & 10 \\
\hline 139 & $858 \mathrm{D}$ & $01 \mathrm{H}$ & 6 & 30 & 33 & 7.80 & ND & ND & ND & ND & ND & ND & ND & ND & ND \\
\hline 139 & $858 \mathrm{D}$ & $02 \mathrm{H}$ & 1 & 115 & 117 & 10.45 & 540 & 1 & 1.6 & ND & 19 & 75 & 46 & 19 & 12 \\
\hline 139 & $858 D$ & $02 \mathrm{H}$ & 1 & 128 & 131 & 10.58 & 540 & 1 & 1.6 & ND & 17 & 75 & 51 & 19 & 10 \\
\hline 139 & 858D & $02 \mathrm{H}$ & 2 & 76 & 78 & 11.56 & 570 & 1 & 1.5 & ND & 21 & 81 & 49 & 18 & 15 \\
\hline 139 & $858 \mathrm{DF}$ & $02 \mathrm{H}$ & 2 & 95 & 98 & 11.75 & 570 & 1 & 1.5 & ND & 23 & 83 & 56 & 20 & 15 \\
\hline 139 & $858 \mathrm{DF}$ & $02 \mathrm{H}$ & 2 & 111 & 113 & 11.91 & ND & ND & ND & ND & ND & ND & ND & ND & ND \\
\hline 139 & $858 \mathrm{DF}$ & $02 \mathrm{H}$ & 3 & 34 & 36 & 12.64 & 980 & 1 & 1.3 & ND & 21 & 89 & 45 & 17 & 16 \\
\hline 139 & $858 \mathrm{DF}$ & $\mathrm{O} 2 \mathrm{H}$ & 3 & 133 & 136 & 13.63 & 760 & 1 & 1.4 & ND & 23 & 90 & 51 & 16 & 14 \\
\hline 139 & $858 \mathrm{DF}$ & $02 \mathrm{H}$ & 4 & 46 & 48 & 14.26 & 600 & 1 & 1.3 & ND & 24 & 93 & 52 & 14 & 14 \\
\hline 139 & $858 \mathrm{DF}$ & $02 \mathrm{H}$ & 4 & 57 & 60 & 14.37 & 800 & 1 & 1.4 & ND & 25 & 91 & 70 & 19 & 13 \\
\hline 139 & $858 \mathrm{DF}$ & $02 \mathrm{H}$ & 5 & 36 & 39 & 15.66 & 760 & 1 & 1.6 & ND & 30 & 91 & 72 & 22 & 16 \\
\hline 139 & $858 \mathrm{DF}$ & $02 \mathrm{H}$ & 5 & 53 & 55 & 15.83 & 1000 & 1 & 1.5 & ND & 30 & 92 & 67 & 19 & 13 \\
\hline 139 & $858 \mathrm{DF}$ & $02 \mathrm{H}$ & 6 & 36 & 38 & 17.16 & 680 & 1 & 1.6 & ND & 25 & 80 & 58 & 20 & 17 \\
\hline 139 & 858DF & $02 \mathrm{H}$ & 6 & 93 & 96 & 17.73 & 660 & 1 & 1.4 & ND & 20 & 72 & 54 & 17 & 14 \\
\hline 139 & $858 \mathrm{DF}$ & $02 \mathrm{H}$ & 7 & 14 & 16 & 18.44 & 2500 & 1 & 1.7 & ND & 18 & 94 & 74 & 17 & 10 \\
\hline 139 & $858 \mathrm{DF}$ & $02 \mathrm{H}$ & 7 & 23 & 25 & 18.53 & 954 & ND & ND & 13 & ND & 101 & 63 & ND & 11 \\
\hline 139 & $858 \mathrm{DF}$ & $02 \mathrm{H}$ & $\mathrm{CC}$ & 10 & 12 & 18.92 & 1100 & 1 & 1.6 & ND & 20 & 82 & 65 & 19 & ND \\
\hline 139 & 858DF & $04 \mathrm{H}$ & 3 & 31 & 35 & 21.85 & 380 & 1 & 1.6 & ND & 16 & 90 & 42 & 19 & 20 \\
\hline 139 & 858DF & $04 \mathrm{H}$ & 3 & 107 & 110 & 22.61 & 470 & i & 1.8 & ND & 25 & 87 & 57 & 20 & 14 \\
\hline 139 & $858 \mathrm{DF}$ & $04 \mathrm{H}$ & 4 & 59 & 63 & 23.63 & 491 & ND & ND & 15 & ND & 114 & 38 & ND & 13 \\
\hline 139 & $858 \mathrm{DF}$ & $04 \mathrm{H}$ & 4 & 64 & 67 & 23.68 & 470 & I & 1.5 & ND & 20 & 87 & 39 & 24 & 16 \\
\hline 139 & 858DF & $04 \mathrm{H}$ & 5 & 35 & 33 & 24.87 & 440 & 1 & 1.8 & ND & 18 & 74 & 37 & 23 & 19 \\
\hline 139 & 858DF & $04 \mathrm{H}$ & 5 & 44 & 48 & 24.98 & 460 & 1 & 1.9 & ND & 23 & 82 & 36 & 26 & 24 \\
\hline 139 & $858 \mathrm{DF}$ & $04 \mathrm{H}$ & 6 & 26 & 29 & 26.30 & 370 & 1 & 1.4 & ND & 21 & 73 & 42 & 15 & 18 \\
\hline 139 & $858 \mathrm{DF}$ & $04 \mathrm{H}$ & 7 & 36 & 40 & 27.90 & 330 & 1 & 1.6 & ND & 15 & 76 & 21 & 17 & 20 \\
\hline 139 & 858DF & $02 \mathrm{R}$ & $\mathrm{CC}$ & 8 & 11 & 27.87 & 40 & 1 & 0.6 & ND & 10 & 58 & 10 & 11 & 22 \\
\hline 139 & $858 \mathrm{DF}$ & 04R & $\mathrm{CC}$ & 8 & 10 & 46.58 & 60 & 1 & 0.5 & ND & 8 & 54 & 10 & 13 & 18 \\
\hline 139 & $858 \mathrm{DF}$ & 08R & $\mathrm{CC}$ & 11 & 12 & 84.81 & 50 & 1 & 0.5 & ND & 5 & 55 & 11 & 16 & 20 \\
\hline 139 & $858 \mathrm{DF}$ & 09R & $\mathrm{CC}$ & 18 & 20 & 94.38 & 122 & ND & ND & 109 & ND & 15 & 166 & ND & 9 \\
\hline 139 & 858DF & $11 \mathrm{R}$ & $\mathrm{CC}$ & 4 & 5 & 114.01 & 30 & 1 & 0.5 & ND & 6 & 22 & 12 & 10 & 16 \\
\hline 139 & 858DF & $12 \mathrm{R}$ & $\mathrm{CC}$ & 2 & 3 & 123.32 & 120 & i & 1.0 & ND & 15 & 51 & 10 & 12 & 14 \\
\hline 139 & $858 \mathrm{DF}$ & $13 \mathrm{R}$ & $\mathrm{CC}$ & 6 & 7 & 132.96 & 60 & 1 & 0.8 & ND & 77 & 48 & 10 & 10 & ND \\
\hline 139 & $858 \mathrm{DF}$ & $13 R$ & $\mathrm{CC}$ & 7 & 9 & 132.97 & 131 & ND & ND & 80 & ND & 66 & 15 & ND & 11 \\
\hline 139 & $858 \mathrm{DF}$ & $14 \mathrm{R}$ & 1 & 10 & 12 & 142.70 & 90 & 1 & 1.5 & ND & 14 & 63 & 10 & 31 & 19 \\
\hline 139 & $858 \mathrm{DF}$ & $15 R$ & $\mathrm{CC}$ & 4 & 6 & 152.24 & 80 & 1 & 0.5 & ND & 17 & 47 & 75 & 10 & 21 \\
\hline 139 & 858DF & $17 R$ & $\mathrm{CC}$ & 16 & 18 & 171.76 & 60 & 1 & 0.5 & ND & 6 & 43 & 10 & 53 & 16 \\
\hline 139 & $858 \mathrm{DF}$ & $18 \mathrm{R}$ & 1 & 14 & 16 & 181.44 & 40 & 1 & 0.9 & ND & 13 & 63 & 10 & 15 & 17 \\
\hline 139 & $858 \mathrm{DF}$ & $21 R$ & 1 & 14 & 16 & 210.44 & 220 & 1 & 1.4 & ND & 26 & 68 & 10 & 14 & 15 \\
\hline 139 & $858 \mathrm{DF}$ & $23 \mathrm{R}$ & $\mathrm{CC}$ & 3 & 5 & 229.63 & 50 & i & 0.7 & ND & 9 & 49 & 49 & 16 & 15 \\
\hline 139 & $858 \mathrm{DF}$ & $25 R$ & 1 & 9 & 11 & 248.99 & 180 & 1 & 1.2 & ND & 19 & 81 & 28 & 15 & 16 \\
\hline 139 & $858 \mathrm{DF}$ & $25 \mathrm{R}$ & 1 & 19 & 21 & 249.09 & 240 & 1 & 1.3 & ND & 14 & 86 & 41 & 14 & 16 \\
\hline 139 & 858DF & $25 \mathrm{R}$ & 1 & 40 & 42 & 249.30 & 229 & ND & ND & 53 & ND & 85 & 19 & ND & 14 \\
\hline 139 & $858 \mathrm{DF}$ & $25 \mathrm{R}$ & 1 & 61 & 63 & 249.51 & 90 & 1 & 1.2 & ND & 32 & 80 & 10 & 13 & 17 \\
\hline 139 & $858 \mathrm{DF}$ & $25 \mathrm{R}$ & 1 & 71 & 73 & 249.61 & 130 & 1 & 1.3 & ND & 29 & 80 & 10 & 10 & 18 \\
\hline
\end{tabular}


Table 1 (continued).

\begin{tabular}{|c|c|c|c|c|c|c|c|c|c|c|c|c|c|}
\hline $\mathrm{Ni}$ & $\mathrm{Pb}$ & $\mathrm{Rb}$ & $\mathrm{Sc}$ & $\mathrm{Sr}$ & V & $\mathrm{Y}$ & $\mathrm{Yb}$ & $\mathrm{Zn}$ & $\mathrm{Zr}$ & $\mathrm{Se}$ & $\mathrm{Sb}$ & As & Mo \\
\hline & \multicolumn{13}{|c|}{ parts per million } \\
\hline 48 & 21 & 83 & 17 & 310 & 130 & 23 & 2.20 & 94 & 130 & 0.45 & 0.29 & 6.5 & 1 \\
\hline 52 & 23 & 78 & 16 & 420 & 130 & 18 & 1.80 & 110 & 110 & 0.78 & 0.75 & 7.4 & 1 \\
\hline 68 & 20 & 64 & 16 & 370 & 130 & 18 & 1.60 & 97 & 120 & 0.49 & 0.58 & 2.9 & 1 \\
\hline 76 & 20 & 59 & 16 & 370 & 130 & 18 & 1.60 & 100 & 120 & 0.47 & 0.74 & 3.5 & i \\
\hline 55 & 20 & 80 & 16 & 400 & 130 & 18 & 1.80 & 100 & 95 & 0.40 & 0.10 & 2.0 & 1 \\
\hline ND & ND & ND & ND & ND & ND & ND & ND & ND & ND & ND & ND & ND & ND \\
\hline 55 & 21 & 110 & 14 & 190 & 110 & 17 & 1.60 & 88 & 100 & 1.49 & 0.78 & 3.5 & 1 \\
\hline 58 & 20 & 110 & 14 & 180 & 110 & 18 & 1.70 & 100 & 100 & 1.10 & 0.69 & 2.8 & $i$ \\
\hline 61 & 21 & 100 & 16 & 180 & 120 & 17 & 1.50 & 120 & 120 & 1.18 & 0.66 & 3.7 & 1 \\
\hline 62 & 26 & 91 & 17 & 170 & 140 & 20 & 1.90 & 120 & 110 & 0.97 & 0.68 & 2.8 & $i$ \\
\hline ND & ND & ND & ND & ND & ND & ND & ND & ND & ND & ND & ND & ND & ND \\
\hline 52 & 20 & 77 & 19 & 170 & 140 & 18 & 180 & 98 & 130 & 0.34 & 0.42 & 4.4 & 1 \\
\hline 65 & 20 & 90 & 18 & 140 & 130 & 17 & 1.60 & 100 & 100 & 0.62 & 0.25 & 4.9 & 1 \\
\hline 65 & 20 & 86 & 19 & 140 & 140 & 15 & 1.40 & 100 & 110 & 0.72 & 0.24 & 3.9 & i \\
\hline 68 & 20 & 88 & 18 & 130 & 140 & 21 & 2.00 & 110 & 110 & 1.05 & 0.39 & 4.0 & 1 \\
\hline 72 & 20 & 110 & 18 & 130 & 140 & 20 & 180 & 120 & 120 & 1.62 & 0.58 & 8.1 & $i$ \\
\hline 67 & 20 & 110 & 19 & 130 & 150 & 19 & 1.70 & 110 & 110 & 1.90 & 0.66 & 12.8 & 1 \\
\hline 41 & 23 & 110 & 18 & 120 & 140 & 20 & 190 & 90 & 120 & 1.22 & 0.80 & 8.4 & 2 \\
\hline 42 & 20 & 95 & 16 & 110 & 130 & 19 & 1.80 & 110 & 96 & 0.90 & 0.68 & 5.0 & 9 \\
\hline 10 & 30 & 110 & is & 120 & 140 & 17 & 1.50 & 130 & 120 & 2.85 & 1.57 & 40.9 & 42 \\
\hline 60 & ND & 109 & ND & 90 & 180 & 19 & ND & 144 & 130 & ND & ND & ND & ND \\
\hline 28 & 32 & ND & 17 & 80 & 140 & 20 & 1.80 & 1500 & 110 & 2.32 & 3.50 & 58.6 & 21 \\
\hline 44 & 20 & 97 & 16 & 85 & 130 & 17 & 1.80 & 97 & 160 & 0.65 & 1.42 & 15.4 & 1 \\
\hline 76 & 20 & 110 & 18 & 77 & 140 & 17 & 1.70 & 140 & 120 & 0.98 & 1.63 & 21.2 & 3 \\
\hline 37 & ND & 108 & ND & 53 & 153 & 19 & ND & 103 & 150 & ND & ND & ND & ND \\
\hline 61 & 23 & 100 & 14 & 67 & 120 & 16 & 1.40 & 110 & 140 & 0.90 & 3.15 & 18.1 & 1 \\
\hline 51 & 20 & 110 & 16 & 60 & 120 & 16 & 1.50 & 140 & 120 & 0.41 & 1.12 & 10.5 & i \\
\hline 62 & 23 & 110 & 15 & 58 & 120 & 16 & 1.40 & 150 & 110 & 0.44 & 2.39 & 18.8 & 1 \\
\hline 61 & 26 & 93 & 15 & 28 & 120 & 21 & 2.00 & 180 & 130 & 1.05 & 2.48 & 28.6 & i \\
\hline 46 & 23 & 64 & 14 & 36 & 110 & 20 & 1.90 & 28 & 110 & 0.99 & 1.10 & 19.1 & $i$ \\
\hline 39 & 20 & 10 & 10 & 20 & 82 & 10 & 0.90 & 44 & 79 & 0.23 & 0.10 & 0.3 & $i$ \\
\hline 27 & 20 & 10 & 8.3 & 20 & 64 & 12 & 1.20 & 37 & 110 & 0.10 & 0.10 & 0.1 & 1 \\
\hline 18 & 20 & 10 & 9.4 & 66 & 60 & 13 & 150 & 19 & 150 & 0.10 & 0.10 & 0.1 & 1 \\
\hline ND & ND & 1 & ND & 54 & 60 & 9 & ND & 12 & 63 & ND & ND & ND & ND \\
\hline 15 & 20 & 10 & 8.2 & 97 & 62 & 8 & 0.80 & 13 & 140 & 0.10 & 0.10 & 0.1 & 1 \\
\hline 28 & 20 & 10 & 17 & 280 & $\begin{array}{r}02 \\
140\end{array}$ & $15^{\circ}$ & $\begin{array}{l}0.00 \\
1.20\end{array}$ & 85 & 110 & 0.10 & 0.10 & 0.6 & 1 \\
\hline 65 & 23 & ND & 11 & 91 & 62 & 13 & 0.50 & 33 & 61 & 5.86 & 0.56 & 15.1 & $i$ \\
\hline 11 & ND & ND & ND & 196 & 112 & 19 & ND & 39 & 119 & ND & ND & ND & ND \\
\hline 33 & 20 & 10 & 16 & 240 & 110 & 18 & 140 & 58 & 160 & 0.10 & 0.10 & 0.7 & 1 \\
\hline 22 & 20 & 14 & 10 & 42 & 51 & 14 & 1.30 & 30 & 130 & 1.61 & 0.10 & 1.6 & 1 \\
\hline 11 & 20 & 10 & 8.4 & 79 & 22 & 11 & 10 & 11 & 91 & 0.10 & 0.10 & 0.3 & $i$ \\
\hline 32 & 20 & 10 & 13 & 120 & 80 & 13 & 1.20 & 42 & 130 & 0.78 & 0.10 & 0.1 & 1 \\
\hline 56 & 20 & 25 & 19 & 120 & 140 & 17 & 140 & 82 & 110 & 0.30 & 0.10 & 3.5 & $i$ \\
\hline 22 & 20 & 10 & 11 & 230 & 74 & 16 & 1.50 & 21 & 140 & 0.30 & 0.10 & 4.3 & i \\
\hline 46 & 20 & 26 & 20 & 190 & 150 & 19 & 1.80 & 80 & 130 & 0.84 & 0.10 & 5.3 & 3 \\
\hline 42 & 20 & 21 & 21 & 180 & 160 & 18 & 1.60 & 94 & 120 & 1.83 & 0.10 & 2.6 & 1 \\
\hline 41 & ND & 12 & ND & 155 & 205 & 19 & ND & 122 & 103 & ND & ND & ND & ND \\
\hline 58 & 20 & 10 & 18 & 210 & 120 & 19 & 1.60 & 70 & 140 & 1.11 & 0.91 & 17.5 & 1 \\
\hline 55 & 20 & 11 & 20 & 180 & 150 & 13 & 1.30 & 98 & 110 & 0.89 & 0.50 & 15.9 & i \\
\hline
\end{tabular}

Notes: $\mathrm{Na}_{2} \mathrm{OC}=\mathrm{Na}_{2} \mathrm{O}-\mathrm{Na}_{2} \mathrm{OX}$ where $\mathrm{Na}_{2} \mathrm{OX}$ is sodium precipitated during drying; $\mathrm{ND}=$ not determined; Ldepth=lower depth of sample interval in cm; Udepth=upper depth of sample interval in $\mathrm{cm} ; \mathrm{TOC}=$ total organic carbon; $\mathrm{Fe}_{2} \mathrm{O}_{3} \mathrm{~T}=$ total $\mathrm{Fe}$ expressed as $\mathrm{Fe}_{2} \mathrm{O}_{3} ; \mathrm{H} 2 \mathrm{OT}=$ water bound in solids, mostly hydrous silicates; element detection limits are: (weight percent) $\mathrm{TiO}_{2}(0.02), \mathrm{MnO}(0.01), \mathrm{MgO}(0.04), \mathrm{CaO}(0.01), \mathrm{Na} 2 \mathrm{O}(0.03), \mathrm{K}_{2} \mathrm{O}(0.05), \mathrm{H} 2 \mathrm{OT}$ (0.1), $\mathrm{CO}_{2}$ (0.1), S (0.04); (parts per million) $\mathrm{Ba}(30), \mathrm{Be}(0.5), \mathrm{Co}(5), \mathrm{Cr}(10), \mathrm{Cu}(10), \mathrm{La}(10), \mathrm{Nb}(10), \mathrm{Ni}(10), \mathrm{Pb}(10), \mathrm{Rb}(10), \mathrm{Sc}(0.5), \mathrm{Sr}(20)$, $\mathrm{V}(5), \mathrm{Y}(5), \mathrm{Yb}(0.5), \mathrm{Zn}(5)$, and $\mathrm{Zr}(10)$. Values less than the detection limit are expressed as one-half the detection limit. 